\title{
Organ donation after euthanasia; medical, legal and ethical considerations
}

Citation for published version (APA):

Bollen, J. A. M. (2019). Organ donation after euthanasia; medical, legal and ethical considerations. [Doctoral Thesis, Maastricht University]. Gildeprint en Universitaire Pers Maastricht. https://doi.org/10.26481/dis.20191101jb

Document status and date:

Published: 01/11/2019

DOI:

10.26481/dis.20191101jb

Document Version:

Publisher's PDF, also known as Version of record

\section{Please check the document version of this publication:}

- A submitted manuscript is the version of the article upon submission and before peer-review. There can be important differences between the submitted version and the official published version of record.

People interested in the research are advised to contact the author for the final version of the publication, or visit the DOI to the publisher's website.

- The final author version and the galley proof are versions of the publication after peer review.

- The final published version features the final layout of the paper including the volume, issue and page numbers.

Link to publication

\footnotetext{
General rights rights.

- You may freely distribute the URL identifying the publication in the public portal. please follow below link for the End User Agreement:

www.umlib.nl/taverne-license

Take down policy

If you believe that this document breaches copyright please contact us at:

repository@maastrichtuniversity.nl

providing details and we will investigate your claim.
}

Copyright and moral rights for the publications made accessible in the public portal are retained by the authors and/or other copyright owners and it is a condition of accessing publications that users recognise and abide by the legal requirements associated with these

- Users may download and print one copy of any publication from the public portal for the purpose of private study or research.

- You may not further distribute the material or use it for any profit-making activity or commercial gain

If the publication is distributed under the terms of Article $25 \mathrm{fa}$ of the Dutch Copyright Act, indicated by the "Taverne" license above, 


\section{Organ donation after euthanasia}

medical, legal and ethical considerations 
The research reported here was carried out at

$$
\text { Maastricht University im Learning! }
$$

(C) Copyright Jan Bollen, Maastricht 2019

Cover design: Jean Scheijen | vierdrie.nl

Layout: Tiny Wouters

Printed by: Gildeprint

ISBN: 9789463238335

Printing of this thesis was financially supported by: Astellas, Stichting Onderzoek Intensive Care, Maastricht Universitair Medisch Centrum, Maastricht University 


\title{
Organ donation after euthanasia
}

\author{
medical, legal and ethical considerations
}

\author{
PROEFSCHRIFT \\ Ter verkrijging van de graad van doctor aan de Universiteit Maastricht, \\ op gezag van de Rector Magnificus, Prof.dr. Rianne M. Letschert \\ volgens het besluit van het College van Decanen, \\ in het openbaar te verdedigen \\ op \\ vrijdag 1 november 2019 om 10.00 uur \\ door
}

Jan Albert Maria Bollen 


\section{Promotores}

Prof. dr. W.N.K.A. van Mook

Prof. dr. L.W.E. van Heurn

\section{Copromotores}

Mw. mr. dr. M.M. ten Hoopen

Prof. dr. D. Ysebaert, Universitair Ziekenhuis Antwerpen, België

\section{Beoordelingscommissie}

Prof. dr. C.G. Faber, voorzitter

Prof. dr. W.L.J.M. Duijst

Prof. dr. L.B. Hilbrands, Radboud UMC Nijmegen

Prof. dr. M.M. Levi, University College London Hospitals, United Kingdom

Prof. dr J.W.M. Muris 


\section{Promotores}

Prof. dr. W.N.K.A. van Mook

Internist-Intensivist, Coördinerend donatie-intensivist

Hoogleraar Professionele Ontwikkeling in de Medische (vervolg) opleidingen i.h.b. de Intensive Care

Directeur Academie Medische Vervolgopleidingen

Maastricht UMC+

Prof. dr. L.W.E. van Heurn

Kinderchirurg, transplantatiechirurg

Hoogleraar en afdelingshoofd kinderchirurgie

Amsterdam UMC

\section{Copromotores}

Mr. dr. M.M. ten Hoopen

Assistent-professor Gezondheidsrecht

Juridisch medewerker Boels-Zanders

Maastricht University

Prof. dr. D. Ysebaert

Diensthoofd hepatobiliaire, transplantatie en endocriene heelkunde

Universitair Ziekenhuis Antwerpen

\section{Beoordelingscommissie}

Prof. dr. C.G. Faber (voorzitter)

Neuroloog

Hoogleraar neuromusculaire aandoeningen

Directeur patiëntenzorg

Maastricht UMC+

Prof. dr. W.L.J.M. Duijst

Forensisch arts bij GGD IJsselland

Hoogleraar Forensische Geneeskunde en Gezondheidsstrafrecht

Maastricht University

Prof. dr. L.B. Hilbrands

Hoogleraar Klinische en experimentele niertransplantatie

Afdelingshoofd nierziekten

Voorzitter Nederlandse Transplantatie Vereniging

Radboud UMC, Nijmegen

Prof. dr. M.M. Levi

Hoogleraar interne geneeskunde

CEO University College London Hospitals (UCLH)

UCLH Londen

Prof. dr J.W.M. Muris

Hoogleraar huisartsgeneeskunde, afdelingshoofd

Maastricht University 

Voor allen die gedoneerd hebben na euthanasie 



\section{Content}

$\begin{array}{lll}\text { Chapter } 1 \quad \text { General introduction } & 11\end{array}$

Huisarts en Wetenschap, Uitgave 2/2018

Chapter 2 Organ donation after euthanasia: A Dutch practical manual American Journal of Transplantation 2016;16(7):1967-72

Chapter 3 Legal and ethical aspects of organ donation after euthanasia in Belgium and the Netherlands Journal of Medical Ethics 2016;42(8):486-9

Chapter 4 Orgaandonatie na euthanasie: juridische overwegingen en vraagstukken

Tijdschrift voor Gezondheidsrecht 2019:107-21

Chapter 5 Potential number of organ donors after euthanasia JAMA 2017;317(14):1476-7

Chapter 6 Promising results of kidney transplantation from donors following voluntary euthanasia Under review

Chapter 7 Organ donation after euthanasia in children: Belgian and Dutch perspectives

Archives of Diseases in Childhood, Archives of Disease in Childhood 2019;104:827-830

Chapter $8 \quad$ Euthanasia through living organ donation: ethical, legal and medical challenges

Journal of Heart and Lung Transplantation 2019;38(2):111-3

Chapter 9 General discussion

Samenvatting 175

Summary

Valorisation

List of publications 209

Dankwoord

Curriculum vitae

SHE dissertations series 


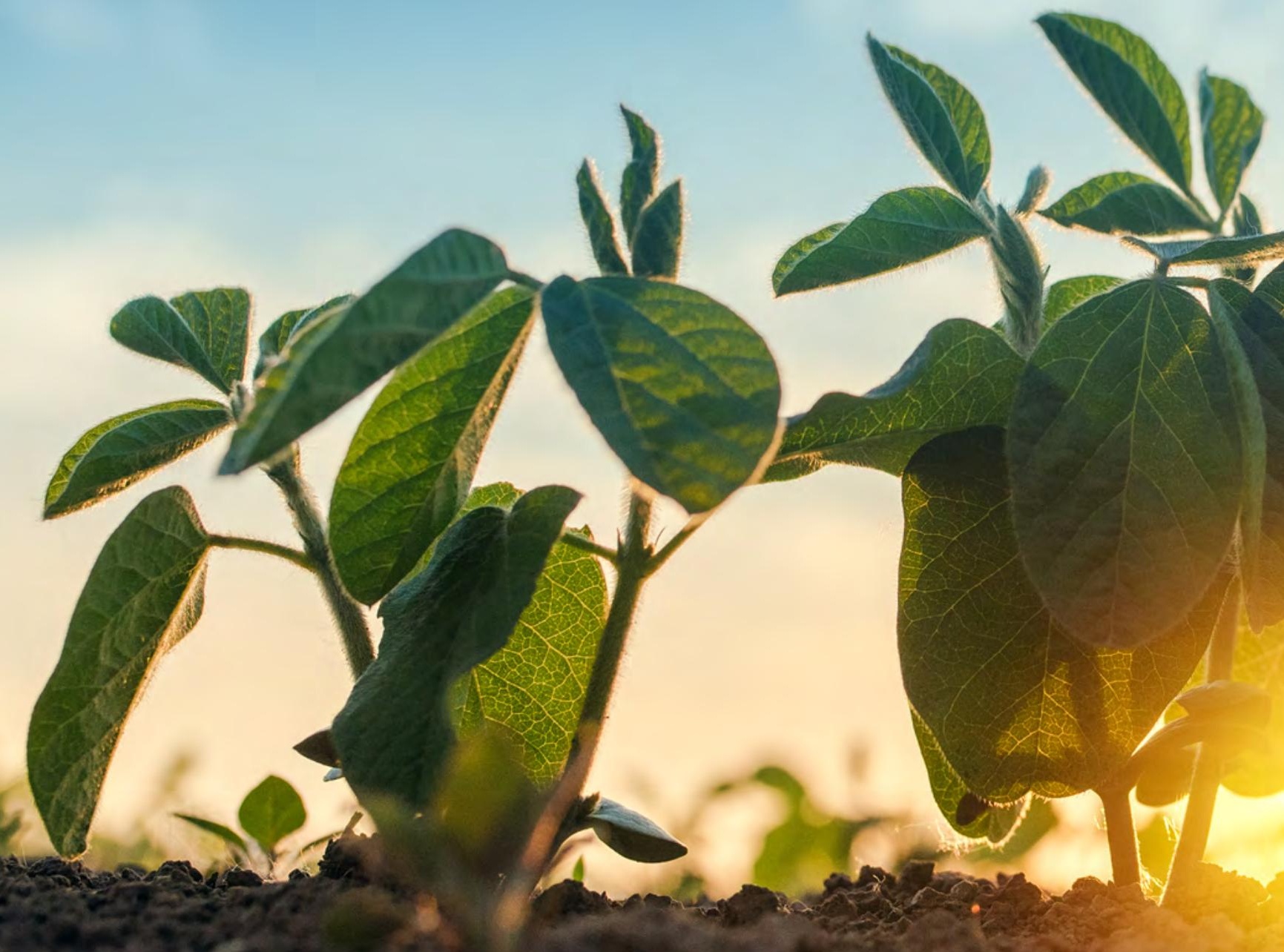




\section{chapter}

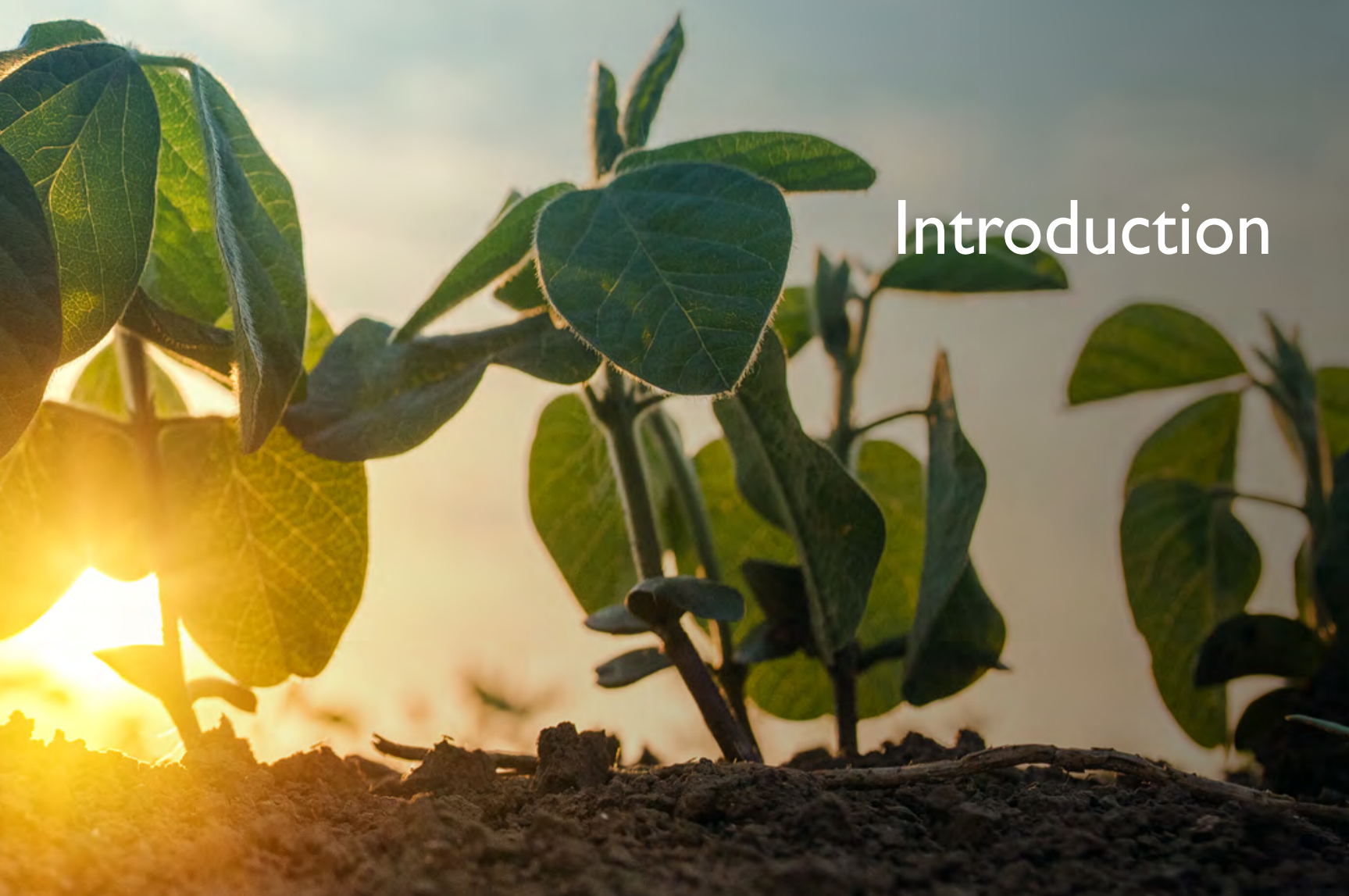





\section{General introduction}

Organ donation after euthanasia is the process in which a patient who fulfills all due diligence requirements undergoes euthanasia and donates his organs. This thesis focuses on the medical, legal and ethical aspects of organ donation after euthanasia in the Netherlands and Belgium.

In the following paragraphs, the principles of euthanasia and organ donation are addressed separately, after which the aspects of the combination of organ donation after euthanasia are explained. The introduction leads to the scope of this thesis, which describes the different research questions, followed by an outline on where these research questions are addressed.

\section{Euthanasia}

It is likely that euthanasia has always existed. Even in the earliest of time the person who was then seen as the 'physician', will probably have helped another person die at his request when he or she was suffering unbearably. Due to the ambiguity of the term euthanasia, it is essential to identify the correct terminology before discussing the history of euthanasia.

\subsection{Terminology}

When talking about end-of-life decisions, multiple terms and abbreviations can be found in international literature that cannot always be defined in the same way. ${ }^{1}$ Surveys conducted among the public and physicians are limited by framing effects and inconsistent wording. In a study performed in 1991 at the request of the Dutch government, preparing a discussion about legislation on euthanasia, Van der Maas et al. elaborated on 'medical decisions concerning the end of life' (MDEL). ${ }^{2}$ This included euthanasia, assisted suicide, life-terminating acts without explicit or persistent request, alleviation of pain and symptoms (APS) and non-treatment decisions (NTD).

In more recent literature, physician-assisted dying/death (PAD) is used as a general term to include euthanasia and assisted suicide, but is often used as a synonym for physicianassisted suicide as well. In Canada, one talks about medical assistance in dying (MAID) as a general term. ${ }^{3}$ In this thesis, euthanasia is defined as a physician administering life ending drugs to a competent patient at his explicit request. For clarity purposes: in this thesis, the term euthanasia (evidently) always refers to voluntary euthanasia, thus the 
result of a voluntary request by the patient. In international literature, one occasionally describes involuntary euthanasia in case there is a mentally competent patient who did not request euthanasia, and nonvoluntary euthanasia when the patient is not mentally competent and could not request euthanasia. ${ }^{4}$ These two types of euthanasia are unacceptable to the authors in this thesis. There is only one exception described in the Groningen protocol, in case there is hopeless and unbearable suffering in a newborn.,

The term passive euthanasie is avoided in the Netherlands, while in international literature this can either mean withdrawal of life sustaining therapy (WLST) or palliative sedation. ${ }^{7,8}$ The latter is only possible when the patient is expected to die within two weeks, and only after informed consent.

The term 'assisted suicide' is used when a physician provides medication or a prescription to a patient at his or her explicit request with the understanding that the patient intends to use the medications to end his life. In some countries, a physician needs to be present when the patient ingests these drugs, to be able to perform euthanasia when the drugs do not function (e.g. because of vomiting).

\subsection{History}

In this section, the emergence of euthanasia will be discussed, after which the development of euthanasia in de contemporary age will be analyzed. Even though euthanasia means 'good death', originating from Greek language, assisted suicide and mercy killing were common and tolerated practices in ancient Greece and early imperial Rome. ${ }^{9}$ The city magistrates of Athens kept a supply of poison to help the dying 'drink the Hemlock' ${ }^{10}$ Contrary to the Hippocratic Oath, physicians commonly ended the lives of dying patients with their consent. ${ }^{11,12}$ Suicide was legally permitted for the ancient Romans, except for slaves, criminals and soldiers. It was viewed as a triumph over fate. The Pythagoreans however condemned euthanasia, based on the spiritual notion that only God had the right to take life.

In the Roman Empire and the Middle Ages, Christianity had a profound impact on the perception of euthanasia. Suicide of any type was strictly forbidden, and in case such an attempt nevertheless occurred, the person's worldly belongings were taken away with the intention of punishing the family by leaving them impoverished. Public perception changed during the Renaissance, when, after hundreds of years, the Christian view was challenged and many Christian assumptions were discarded. Through the rise of humanism in the beginning of the 19th century, the right and responsibility for an 
individual to shape his own life was of increasing importance. For some, this led to the opinion that euthanasia might not be such a grievous sin after all.

In Western Europe, the term euthanasia was used during the history of mass killing during the Nazi era, and therefore has a pejorative meaning. ${ }^{13-15}$ While since the creation of the European Union the member states increasingly share policies, laws and an economy, deeply rooted differences about promoting the sanctity of life, eradicating suffering, and respecting patients' autonomous wishes remain. ${ }^{16}$

In the European Convention on Human Rights, drafted in 1950, article 2 states that everyone's right to live shall be protected by law. No one shall be deprived of his life intentionally except for the execution of a court sentence following conviction of a crime for which this penalty is provided by law. Some patients tried to interpreted this right as a right to die as well.

The most famous one is the case of Diane Pretty from the United Kingdom in 2002 who suffered from a motor neuron disease. Because of her disease, she could not commit suicide alone and wanted her husband to help her, which was refused by the local authorities. The European Court of Human Rights held that the right to life could not, without a distortion of language, be interpreted as conferring the diametrically opposite right, namely a right to die. ${ }^{17}$ Dianne Pretty eventually died from lung problems later that year. ${ }^{18}$ In contrast, during that same year, the High Court in London held that Ms B, a 43 year old patient who was paralyzed from the neck down and on a ventilator, was entitled to end her life by refusing further life support. ${ }^{19}$

In other cases before the European Court, the right of obtaining a lethal substance to commit suicide has been discussed (Haas v. Switzerland, 20 January 2011; Koch v. Germany, 19 July 2012; Gross v. Switzerland, 30 September 2014). The Court decided that the States enjoy a 'considerable' margin of appreciation in the context of assisted suicide, in light of the absence of a European consensus on the matter. Although assisted suicide has been decriminalized in some member States, the majority appears to attach more weight to the protection of the individual's life than to his right to end it. $^{20}$

Studies by Cohen et al. investigated the trends in acceptance of euthanasia. Between 1981 and 1999, a significant increase in acceptance was observed in all investigated European countries, except (West) Germany. An increase of euthanasia acceptance among the general public was observed, possibly indicating a growing support for 
personal autonomy regarding medical end-of-life decisions. ${ }^{21}$ In Central and Eastern European countries, acceptance of euthanasia decreased or did not increase between $1999-2008$ in 8 of 10 countries. $^{22}$ Evaluating the data of the European Values Studies (EVS) in 2014 again suggested a polarization in Europe, with most of Western Europe becoming more permissive and most of Eastern Europe becoming less permissive, making a pan-European policy approach on the issue difficult. ${ }^{23}$

In the United States, the end-of-life issue in the contemporary, modern era is discussed since the case of Karen Ann Quinlan. She was 21 years old in 1975 when she became unconscious and ended up in a persistent vegetative state after consuming Quaaludes and alcohol while on a crash diet. Her parents had to go to court to have her removed from the ventilator in 1985. Nancy Cruzan was 25 years old in 1983 when she crashed into a ravine and was in a persistent vegetative state, not depending on a ventilator, but kept alive because of artificial nutrition. The U.S. Supreme Court declared that the right to die was a constitutionally protected liberty interest, maintaining that the right to refuse treatment is guaranteed through the liberty clause in the Constitution of the United States of America. The state court then allowed the feeding tube to be removed in $1990 .^{24,25}$

From the United States, one might also still remember the Terri Schindler Schiavo case. She suffered from cardiac arrest in 1990 when she was 26 years old and lapsed into a persistent vegetative state, without any advance directives. Her husband told the court that his wife told him several times during their marriage she would not want to be kept alive on life support. Her parents however contradicted this, supported by physicians who argued she was not in a persistent vegetative state. The court agreed with her husband, and Terri Schiavo died in 2005 after artificial nutrition and hydration were discontinued. ${ }^{26}$ These cases are not about euthanasia, but reflect the end-of-life debate in the US.

Currently, euthanasia is only legally allowed in Belgium, the Netherlands, Luxembourg, and outside the European Union in Colombia and Canada. In the next paragraphs, the legalization of euthanasia in Belgium and the Netherlands will be discussed. From 2002 to 2018 , this has led to 81418 euthanasia cases in both countries combined (Table 1.1). 


\subsection{Euthanasia in the Netherlands}

The societal debate about euthanasia in the Netherlands was triggered in 1973 by the so-called 'Postma case'. ${ }^{27}$ A physician helped her terminally ill mother end her life following repeated and explicit requests for euthanasia. The physician received a short, suspended sentence, because the court acknowledged a physician does not always have to keep a patient alive against his or her will when faced with pointless suffering. The court subsequently stated that life-shortening action can be justified if the patient is incurably ill due to illness or accident, causing unbearable physical or mental suffering, while the patient has indicated that he wants to end his life, and the procedure was performed by a physician. ${ }^{28}$ This ruling led to the foundation of the Nederlandse Vereniging voor een Vrijwillig Levenseinde (Dutch Association for a Voluntary End of Life). Another case that influenced the prosecution policy was the Wertheim case in 1981, in which Ms. Wertheim helped another woman die by giving her medication and alcohol. The deceased had requested death because she lived isolated, was an alcoholic, and thought she was suffering from cancer. The court stated that it is possible to appeal to a state of emergency when performing assisted suicide, but Ms. Wertheim was not a physician and there were still other reasonable options available. The 76 year old Ms. Wertheim received a conditional prison sentence of six months.

In 1984, the Dutch Supreme Court acquitted a physician who performed euthanasia on a 95-year-old patient who experienced general deterioration and loss of dignity. In this 'Schoonheim case', the Court concluded the physician acted in a situation of necessity, in a dilemma between the duty to relieve suffering and the duty not to harm. ${ }^{28-30}$

These cases led to a report published in 1985 by a State Commission that defined euthanasia as 'intentionally terminating another person's life at the person's request', including a series of criteria for due care to be met in every case of euthanasia. The Commission proposed that the Criminal Code would be amended so that the intentional termination of another person's life at the latter's request would not be an offense if carried out by a physician on a patient who is 'in an untenable situation with no prospect of improvement'. ${ }^{31}$

The report did not focus on psychiatric suffering, which created an intense public debate in 1994 during the Chabot case, where a psychiatrist helped a patient to kill herself, because of psychiatric suffering. The Dutch Supreme Court reasoned that psychiatric suffering could justify assisted suicide, but that a second independent psychiatrist should have investigated the patient. The accused was judged to be guilty without any punishment. 
Research in 1995 demonstrated that Dutch general practitioners and nursing home physicians had a fairly positive attitude toward euthanasia and physician-assisted suicide. The majority however favored a policy of euthanasia and physician-assisted suicide under strict conditions. ${ }^{32}$ Public acceptance of euthanasia in the Netherlands grew as well in that period, from nearly 50\% in 1966 up to $90 \%$ in $1998 .^{2}$ By then the practice of euthanasia was already accepted for over 20 years, protected by a body of case law and strong public support. ${ }^{33}$

The Termination of Life on Request and Assisted Suicide Act of 2002 was the result of a lengthy developmental process. It codified the requirements that have evolved in case law and medical ethics since 1973. By then, euthanasia and assisted suicide already occurred in $2.7 \%$ of all deaths. ${ }^{34}$

Article 293 of the Dutch Penal Law was adjusted, an now states that a person who deliberately terminates the life of another person to his explicit and serious desire, shall be punished, unless this is committed by a physician who meets the due diligence requirements referred to in Article 2 of the Act on termination of life on request and assisted suicide and communicates this to the municipal coroner in accordance with Article 7, second paragraph, of the Law on funeral services. That Article 7 states that euthanasia is considered to be an unnatural death. ${ }^{35}$

The due diligence requirements of Article 2 of the Act on termination of life on request and assisted suicide state that a physician has the possibility to perform euthanasia when he;

a. was convinced that there was a voluntary and well-considered request from the patient,

b. was convinced that there was hopeless and unbearable suffering of the patient,

c. has informed the patient about his situation about his prospects,

d. has come to believe, together with the patient, that there was no reasonable alternative for the current situation,

e. has consulted at least one other, independent physician, who has seen the patient and gave his judgment in writing about the due care requirements referred to in subsections a to $d$, and

f. has carried out the life-saving or assisted suicide with suitable medical care.

The Royal Dutch Society for the Promotion of Pharmacy has written a guideline on the medication that should be used for euthanasia or assisted suicide. In 2018, the regional 
review committees published a 'Euthanasia Code', replacing the code of practice from 2015. This document describes the relevant jurisprudence and further clarifies the law. These guidelines do not have the same 'weight' as law, but a physician still has to justify himself before court or the review committee on euthanasia when he did not act according to a guideline.

Between 2002 and 2018, nearly 80.000 patients underwent euthanasia. Only in that last year the number of euthanasia cases decreased compared to the year before. In 2017 and 2018 together, there were only 18 cases ( $0.15 \%$ of 12.711 cases) where not all due diligence requirements were met, according to the review committees. In 15 of these reports, the public prosecutor and health care inspection already decided there is no reason for further criminal or disciplinary prosecution, and dismissal has been made. ${ }^{36}$ Since the legalization, there is a frequent discussion about euthanasia in patients suffering from dementia and after 'completed life'.

\subsection{Euthanasia in Belgium}

Organized action in favor of the legislation of euthanasia started in Belgium in the 1980s with the foundation of the Association belge pour le droit de mourir dans la dignité (Belgian Association for the Right to Die with Dignity) and its Flemish counterpart Vereniging voor het recht op waardig sterven (Association for the Right to Die with Dignity). ${ }^{37}$

Between 1984 and 1996, nine euthanasia bills were proposed about euthanasia, but none of them passed the House of Representatives. One proposal bill was rejected that did not deal with euthanasia as such, but that added two provisions to the Penal Code on the basis of which a physician would not be obliged to continue 'treatment or resuscitation' of a patient, with or without the patient's request. In practice, it was already generally accepted that physicians could stop futile medical treatment, but one still had to wait until 2002 before euthanasia was legalized.

The term euthanasia was already used in these proposal bills, sometimes only for patients where pain relief was no longer effective, sometimes only after a written request or in the last phase of a terminal illness or suffering from a disease leading to death. As long as the Christian Democrats were in the Government, none of the proposed bills stood a chance of being dealt with in the Parliament. Nevertheless, endof-life practices seemed fairly common, demonstrated by a survey by Deliens et al. A $20 \%$ random sample of 3999 deaths was selected from all deaths recorded between Jan 1 and April 30, 1998, after which a questionnaire was sent to the physician who signed 
the death certificate. It was estimated that $705(1,3 \%)$ of all deaths resulted from euthanasia or physician assisted suicide, and it was estimated that in 3,2\% of all deaths, lethal drugs were given without the explicit request of the patient. Alleviation of pain and symptoms with opioids in doses with a potential life-shortening effect preceded death in $18,5 \%$ of all deaths and non-treatment decisions in $16,4 \%$, of which $5,8 \%$ with the explicit intention of ending the patient's life. ${ }^{38}$

The results of a survey that was published in 2003 by Van der Heide et al. studied 2950 deaths, in which 1,82\% an end-of-life decision was involved, including 0,3\% euthanasia cases and $1,5 \%$ ending of life without the patient's explicit request. ${ }^{39}$ In contrast to the Netherlands, there was no case law to discuss, since there were hardly any cases of prosecution or punishment of physician assisted dying. ${ }^{40}$ The legislative process on euthanasia that led to the current Euthanasia Act began in 1997, when a federal committee was set up, consisting of physicians, lawyers, ethicists, psychologists, and sociologists. In Opinion no. 1 of 12 May 1997 of the Belgian Advisory Committee on Bioethics concerning the advisability of a legal regulation on euthanasia, there were four different proposals, reflecting the views of four groups within the committee:

- Making euthanasia legal (removing it from the Penal Code);

- Making euthanasia possible with after-the-fact control;

- Euthanasia with a before-the-fact control, but also making procedures on other medical behavior that potentially shortens life;

- Do not allow euthanasia, under any condition.

Following elections, there was a new majority in the Parliament that consisted of political parties that were in favor of the right of self-determination. This led to a thorough debate in the Senate, including hearings with experts. After multiple votes in commissions, amendments, changes in the text and an advice of the Council of State, the Senate approved the bill with 44 votes to 23 . The Chamber of Representatives then approved the bill - again after discussing it in several commissions - in May 2002. ${ }^{41-43}$ When a patient undergoes euthanasia, this is registered as a natural death. ${ }^{44}$

The Belgian Euthanasia Act states that the physician who applies euthanasia does not commit a crime when he has assured himself that:

- $\quad$ the patient is a legally competent adult, or an emancipated minor, or a mentally competent minor and is conscious at the time of his request;

- $\quad$ the request is voluntary, well considered and repeated, and has not arisen as a result of any external pressure; 
- the adult or emancipated minor is in a medically hopeless state of persistent and unbearable physical or psychological suffering that cannot be treated, and which is the result of a serious and incurable condition caused by an accident or illness;

and he has complied with the conditions and procedures prescribed by this Act.

According to the next paragraph of the law, the physician also must inform the patient about his health and his life expectancy, and discuss any remaining therapeutic and palliative options. He also has to consult another independent physician who examines the file and the patient to be assured of the suffering. Contrary to the Netherlands, if the physician is of the opinion that the adult or emancipated minor patient will obviously not die within the foreseeable future, he must also consult a second physician, who is a psychiatrist or specialist in the disorder the patient is suffering from, and inform him of the reasons for this consultation. The consulted physician examines the medical file, examines the patient and has to make sure of the persistent and unbearable physical or psychological suffering that cannot be satisfied, and of the voluntary, considered and repeated character of the request. He draws up a report of his findings. The consulted physician must be independent of both the patient and the attending physician and the first physician consulted. The attending physician informs the patient of the results of this consultation. The physician then has to keep at least one month between the written request of the patient and performing euthanasia.

\begin{tabular}{lrc}
\hline & Belgium & Netherlands \\
\hline 2002 & 24 & 1882 \\
2003 & 235 & 1815 \\
2004 & 349 & 1886 \\
2005 & 393 & 1933 \\
2006 & 429 & 1923 \\
2007 & 495 & 2120 \\
2008 & 704 & 2331 \\
2009 & 822 & 2636 \\
2010 & 953 & 3136 \\
2011 & 1133 & 3695 \\
2012 & 1432 & 4188 \\
2013 & 1807 & 4829 \\
2014 & 1928 & 5306 \\
2015 & 2022 & 5516 \\
2016 & 2028 & 6091 \\
2017 & 2309 & 6585 \\
2018 & 2357 & 6126 \\
Total & 19420 & 61998 \\
\hline
\end{tabular}

Table 1.1 Number of euthanasia cases in Belgium and the Netherlands 
The number of reported euthanasia cases increases every year, from 235 ( $0.2 \%$ of all deaths) in 2003 to 1807 (1.7\% of all deaths) in 2013. Most of those receiving euthanasia were younger than 80 years and were dying of cancer. 45,46

\subsection{Physician assisted dying in the world}

For organ donation after euthanasia to be possible, it is necessary that both DCD and euthanasia are legal in a specific country. ${ }^{47}$ As stipulated in this thesis, euthanasia in humans is possible in Belgium, the Netherlands and Luxembourg. Colombia and Canada have legalized this procedure as well while drafting of this thesis. ${ }^{4,48}$ By discussing surveys where the opposition of physicians changed, Roehr demonstrates that controversy on euthanasia subsided after legalization in the US and Canada. ${ }^{49} 54 \%$ of physicians supported physician assisted dying in a Medscape poll in 2014, compared to $6 \%$ in 2010. ${ }^{50}$ The American Medical Association (AMA) and the American College of Physicians however still oppose physician assisted suicide, since they believe it would ultimately cause more harm than good. ${ }^{51,52}$

The majority of people in the world seem to condemn euthanasia, often arguing that euthanasia creates a 'slippery slope' for killing vulnerable patients. This term is commonly used when referring to the expansion of intentionally ending the life of patients who did not make an explicit request. Opponents also argue that physicians and policy makers will perform euthanasia to reduce costs. According to Emanuel et al., in no jurisdiction was there evidence that vulnerable patients have been receiving euthanasia or physician-assisted suicide at rates higher than those in the general population. ${ }^{4}$

To demonstrate that end-of-life decisions are not as commonly accepted as people in the Benelux often think, an overview of the legislation on physician assisted dying in various countries is provided in the next paragraphs. Other countries are still strictly opposed to physician assisted dying.

\subsubsection{Euthanasia}

Next to Belgium and the Netherlands, euthanasia is possible in Luxembourg, Colombia and Canada. In Luxembourg, euthanasia is possible since 2009: physicians who carry out euthanasia and assisted suicides will not face penal sanctions or civil lawsuits as long as they first consult a colleague to ensure that the patient has a terminal illness, is in a grave and incurable condition, and has repeatedly asked for the right to die. ${ }^{53}$ Physicians must also check with the National Commission for Control and Assessment to see whether end of life provisions have been registered for that patient and must then notify 
the commission of the death within eight days, after which its members evaluate whether all requirements were met. Thiopental is used. Non-residents can ask for help to die, but the terms of the legislation require a close physician-patient relationship. ${ }^{54}$

In 1997 the Colombian Constitutional Court decriminalized 'mercy homicide', arguing that "Nothing is more cruel than to force a person to survive in the midst of shameful suffering, in the name of other people's beliefs". The Ministry Of Health legalized this procedure in April 2015. Intravenous life ending drugs are administered by physicians in a hospital. Euthanasia is eligible to patients with a terminal disease that produces severe pain and suffering that cannot be relieved. The patient must consciously request an assisted death, and authorization and supervision are needed from a medical specialist, a lawyer, and a psychiatrist or clinical psychologist. ${ }^{55}$

In 2017 the Court even ordered the Department of Health and Social Protection to issue regulations which would "guarantee the right to death worthy of children and adolescents". On March 9, 2018, Resolution 825 was issued, which allowed euthanasia for children over 6 . The Department explained that before that age children cannot grasp the idea of their own death. However, children between the ages of 7 and 12 are allowed access euthanasia with the approval of their parents. Children between 12 and 14 can access it even if one parent disagrees. After 14, no parental involvement is needed, provided that all the requirements for euthanasia are fulfilled. Like adults, the child must have an incurable condition, have unmanageable pain and the mental capacity to consent. In its rulings, the Court refers multiple times to the Dutch and Belgian euthanasia acts.

In Canada, the province of Quebec had passed end-of-life care legislation in June 2014, only two years before the federal Criminal Code was changed. This law amendment was initiated by the case of Gloria Taylor, who suffered from amyotrophic lateral sclerosis, and a couple who accompanied Lee Carter's mother to Switzerland, to peacefully end her life. Together with the British Columbia Civil Liberties Association, they argued that provisions against physician assisted-dying are unconstitutional because they deny individuals the right to have control over fundamental personal choices. The British Columbia Supreme Court found that the prohibition of physician assisted suicide was legislatively overbroad and grossly disproportionate to the objectives it is meant to accomplish, with a disproportionate effect on people with disabilities. The prohibition against physician-assisted dying violated the constitutional right to "life, liberty, and security of the person". The court then provided the federal government with 12 months to enact the necessary legislation. The Canadian government enacted Bill C-14, 
legalizing medical assistance in dying (MAID) ${ }^{56,57}$ This term is used to refer to both physician-assisted suicide and euthanasia.

The federal law permits physicians and nurse practitioners, to provide an assisted death for competent adult patients who make a voluntary request, who have been informed of means available to alleviate their suffering, and who have a 'grievous and irremediable' condition. Its definition is that natural death must be reasonably foreseeable and that the person must be in an advanced state of irreversible decline in capabilities. The law does not allow for advanced requests; nor does it include mature minors or patients whose psychiatric condition is the sole driver of the request. ${ }^{58,59}$ Not in every region the health practitioners is obliged to be present during self-administered MAID, while selfadministered assisted death is not allowed in the province of Quebec. ${ }^{60}$

The Canadian Medical Association initially resisted assisted dying. But after the country's high court ruled it to be a fundamental human right, the association embraced the decision and participated in writing the law, provincial regulations, and training its members to implement that ruling. ${ }^{49}$ After the implementation of MAID, researchers proposed the introduction of organ donation after euthanasia as well. ${ }^{61,62}$

In the recent general election in Spain, the debate about euthanasia became a prominent issue after a 70-year-old man was arrested after he administered a lethal dose of sodium pentobarbital to his 61-year-old wife who was suffering from long-term multiple sclerosis. A euthanasia bill was discussed in Parliament in October 2018, but was opposed by conservative parties. Spanish prime minister Pedro Sánchez promised to legalize euthanasia if he would win the elections. His party gained 38 seats, but the results of other parties might make a minority government necessary. ${ }^{63-65}$

\subsubsection{Assisted suicide}

$18,2 \%$ of the United States population lives in jurisdictions where physician aid in dying is now legal, which confronts physicians with new challenges. ${ }^{45,66}$ Euthanasia remains illegal. The Oregon Death with Dignity Act (DWDA) makes it legal for physicians to prescribe life-ending medications to patients, with the patients self-administering the drugs to end their life, but this is only possible in adult state residents of sound mind with a disease judged to be terminal, who have a life expectancy of six months or less. ${ }^{67}$ Most often secobarbital is prescribed. The prescribing physician is free to attend the death or not. ${ }^{68}$ Vermont has published identical legislation in 2013 permitting assisted dying. ${ }^{69,70}$ In 2017, the Vermont Medical Society changed its position on the law, stating 
it provides for a legal option whose use is up to patients and that members are free to decide whether they wish to participate in the law. ${ }^{71}$

Montana bars the prosecution of physicians who assist terminally ill patients to die since a 2009 court ruling determined that such prosecutions would violate the state's constitution. ${ }^{72}$ A New Mexico court issued a similar ruling, but it was reversed on appeal. In a split decision, a majority of the court concluded that aid in dying is not a fundamental liberty interest under the New Mexico Constitution. ${ }^{73}$ An attempt to introduce an assisted suicide bill which would have permitted non-physicians to diagnose the patient and prescribe the lethal drugs, failed in the Senate on March 15, 2017 by a vote of $20-22 .^{74}$

The California legislature approved the California End of Life Option Act in September 2015, beginning implementation from June 2016 onwards. $^{75,76}$ In May 2018 however, the Superior court of Riverside County ruled that the method of enacting the law was unconstitutional. $^{77}$ The District of Columbia Death with Dignity Act of 2016, D.C. Law 21-182, was effective on February 18, 2017 and applicable as of June 6, 2017. This act allows terminally ill adults seeking to voluntarily end their life, to request lethal doses of medication from licensed physicians in the District (MD/DO). Terminally ill patients must be District of Columbia residents who have been medically confirmed to have less than six months to live. ${ }^{78}$ The 2019 federal budget proposed in the U.S. House of Representatives again (see below) contains a rider repealing the D.C. Death with Dignity Act.

In Hawaii, assisted dying became legal on January 1, 2019, after approving a medical aidin-dying law on April 5, 2018 called 'Our Care, Our Choice Act'. Two health care providers are required to confirm a patient's diagnosis, prognosis, ability to make decisions and that the request is voluntary. A counsellor also must determine that the patient isn't suffering from conditions that may interfere with decision-making, such as a lack of treatment of depression. The patient must make two oral requests for the life-ending medication, with a 20-day waiting period in between, and sign a written request witnessed by two people, one of whom can't be a relative. ${ }^{79,80}$

The Washington Death with Dignity Act has been in effect since March 5, 2009. ${ }^{81}$ Between 2009 and 2017, 1401 people 'participated', while 1364 are known to have died. $^{82}$ On November 8, 2016, Colorado voters passed Proposition 106, the End of Life Options Act. ${ }^{83}$ The law went into effect on December 16, 2016. ${ }^{84}$ Although many critics of aid in dying have been concerned that legal recognition of the practice would result in 
a slippery slope to abuse, Orentlicher identified that those fears have not materialized in Oregon, Washington, or the other states that have given formal recognition to aid in dying. ${ }^{85}$ The author defends that by restricting aid in dying to competent and terminally ill adults, the law can ease the dying process for patients, and their families, and avoid the potential for the mistreatment of patients. Ganzini interviewed family members of Oregonians who underwent aid in dying. Comparing family members of those who requested aid in dying to those who did not revealed no differences in primary mental health outcomes of depression, grief, or mental health services use. ${ }^{86}$

During the 9 months between July, 1996, and March, 1997, the provision of euthanasia for the terminally ill was legal in the Northern Territory of Australia. ${ }^{87}$ The Australian state Victoria approved a new bill in November 2017, making it possible for Victorians with a terminal illness to be able to obtain a lethal drug within 10 days of asking to die, after completing a three-step process involving two independent medical assessments. They had to be over the age of 18 , of sound mind, living in Victoria for at least 12 months and to be suffering in a way that cannot be relieved in a manner the person deems tolerable. This procedure will be legal from 2019 onwards. ${ }^{88,89}$

In Switzerland, Article 115 of the Penal Code only permits assisted suicide if the person assisting does so for 'unselfish reasons', which does not require a physician to be involved. Assisted suicide is not restricted to people with terminal illness or to Swiss residents. Oral drugs including sodium pentobarbital have been used. ${ }^{90,91}$

Oregon's law served as a model for the Assisted Dying Bill that was debated by the United Kingdom House of Commons. ${ }^{92}$ Members of Parliament however have rejected plans for a right to die in England and Wales in their first vote on the issue in almost 20 years. Two physicians and a High Court judge would have needed to approve each case. ${ }^{93}$ The Royal College of Physicians has reaffirmed its position in 2014 against assisted dying after a survey of its fellows and members showed that most did not support a change in the law. However, the survey showed a shift in opinion since the college carried out an identical survey in 2006: the members who opposed a change in the law on assisted dying decreased by $10.7 \%{ }^{94}$

In Germany, euthanasia remains a very sensitive subject because of the Nazi history. In 2015, the country passed a law ( $\$ 217$ StGB) prohibiting persons from aiding others in committing suicide on a regular, repetitive basis. In 2017, Germany's federal court decided that, under 'extreme circumstances', people should have legal access to drugs to end their own lives. The purchase of deadly drugs in Germany is forbidden, but the 
court found that the right of self-determination meant there should be exceptions for extreme cases "if, because of their intolerable life situation, they had freely and seriously decided to end their lives" and if there were no palliative-medical alternatives. ${ }^{95}$ In April 2019, the German Federal Constitutional Court initiated hearings on whether physicians can aid terminally ill patients in ending their own lives. ${ }^{96}$ In the same month, the German Federal Court of Justice ruled that physicians do not have to pay damages for prolonging life by artificial means, after a son had initiated a court case for keeping his father alive for five years with a feeding tube. The judges stated that no third party is entitled to judge the value of a life. ${ }^{97}$

It can be concluded that physician assisted suicide is gaining increasing importance and acceptance. Euthanasia is still an exception, while acceptance is growing, especially in countries where it has been legalized. People and health care professionals seem to understand that a patient should be able to decide about his own dignified death, and should thus be able to choose assisted suicide - and now even a combined with organ donation. Depending on the political and religious issues, an increasing number of countries will probably allow physician assisted suicide in the future.

The Canadian physicians Quinn and Detsky identify that the main reason pro physician assisted death in an article they wrote after their first MAID procedure;

We learned the following lesson from this experience. When many of our other patients died, the hardest part for the family was dealing with the uncertainties; when will they die, how would they die, what will it look like, is he or she in pain? And they have to make serial decisions; when to stop blood work, intravenous hydration, vital signs, and remove tubes? All of these uncertainties and decisions induce enormous distress. With MAID, all of that uncertainty and agonized decision making is removed. As a result, the family and the patient undergo much less stress.

"Today we did a good thing," one of us remarked to the other during a mentoring moment when leaving the hospital that evening. We're not sure if we'll ever do this again, but we believe that in this circumstance it was the right care, for the right patient, at the right time. ${ }^{98}$

\section{Organ donation}

Organ donation has only been performed for just over half a century, and is still being improved in various ways. The combination of organ donation and euthanasia is only a very recent evolution, which can only be accepted by people if they accept euthanasia as 
well. In the next paragraphs, the history and procedures related to organ donation will be discussed.

\subsection{History}

Researchers were already experimenting with transplantation in the $19^{\text {th }}$ century, which eventually led to the first successful skin transplant in $1869 .{ }^{99}$ Jacques-Louis Reverdin discovered that small, thin (split thickness) grafts would heal. ${ }^{100,101}$

\subsubsection{Kidney transplantation}

In 1933, the first human-to-human kidney transplant was performed but never functioned due to mismatches in donor and recipient blood groups. The first successful organ transplant was performed in 1954 when a living donor gave a kidney to his identical twin, thus avoiding rejection of the organ in the recipient. ${ }^{102}$ Nine years later the first successful deceased donor kidney transplantation was performed by Merril and Murray. ${ }^{103}$ The success of kidney transplantation increased thanks to tissue typing and immunosuppression advancements in the 1960s. More recently, organ preservations have been developed, making it possible to safely preserve kidneys for up to 48 hours. This makes it possible to allocate donated kidneys to the best matching recipient.

In 2018, in the Eurotransplant region, there were 1326 living kidney donor transplants and 3513 deceased kidney donor transplants, while 10791 patients were on the waiting list by the end of that year.

\subsubsection{Liver transplantation}

After experiments with liver transplantation in dogs, the first liver transplantation in man was performed in 1963 by Thoms Starzl. ${ }^{104,105}$ The first attempt resulted in failure on the operating table due to uncontrolled bleeding. The course of the second two patients established the feasibility of such an operation in humans, despite the fact that death occurred 22 and $7 \frac{1}{2}$ days after transplantation from pulmonary emboli. ${ }^{106,107}$ Only four years later a recipient survived for more than six months.

From the handful of pioneering programs, liver transplantation has expanded to hundreds of programs in more than 80 countries. Ongoing challenges of liver transplantation include those concerning donor organ shortages, recipients with more advanced disease at transplant, growing need for retransplantation, toxicities and adverse effects associated with long-term immunosuppression, obesity and nonalcoholic 
steatohepatitis epidemics, hepatitis $\mathrm{C}$ recurrence and the still inscrutable biology of hepatocellular carcinoma. ${ }^{105}$

\subsubsection{Lung transplantation}

Henri Metras, in 1950, reported the first successful dog lung transplant and the first bronchial artery and left atrial anastomoses. It was found that occasionally a dog could survive temporarily on the function of the lung transplant alone, especially if the respiratory reflexes from the unexcised lung had been preserved. ${ }^{108-110}$ The first human lung transplantation was performed successfully by James D. Hardy and his team. The new lung worked properly for the subsequent 18 days. At that time immunosuppression was based on the administration of azathioprine and prednisone, and it included mediastinal irradiation. The patient died of renal failure and infection. ${ }^{111}$

The first lung recipient who lived for ten months had his surgery in Ghent (Belgium). ${ }^{112,113}$ Advances in lung preservation, surgical technique, and immunosuppression regimens have resulted in the routine performance of lung transplantation around the world for an increasing number of patients, with wider indications.

\subsubsection{Heart transplantation}

In 1967, Christiaan Barnard led the team that performed the world's first human-tohuman heart transplant at Groote Schuur Hospital in Cape Town, South Africa. Although the first heart transplant patient survived only 18 days, four of Groote Schuur Hospital's first 10 patients survived for more than one year, two living for 13 and 23 years, respectively. ${ }^{114}$ In the years following, researchers developed immunosuppressant drugs that improved the success rate of organ transplants throughout the world.

\subsubsection{Eurotransplant}

In Europe, the practice of organ transplantation was improved by the foundation of Eurotransplant in 1967 by Van Rood. Every donor of the participating center provided information of their transplant candidates, in order to select from the waiting list the patient with the best possible match. This allocation of organs led to an enormous improvement of the kidney graft survival. Eurotransplant is now responsible for the allocation of donor organs in Austria, Belgium, Croatia, Germany, Hungary, Luxembourg, the Netherlands and Slovenia. 


\subsection{Types of organ donation}

Medical professionals currently make a distinction between living and deceased donation. Living donation implies that someone donates e.g. one of his kidneys to a patient in need of an organ, while being alive. Matching the human leukocyte antigen ( $\mathrm{HLA}$ ) between donor and recipient is of utmost importance. Because of the ongoing organ shortage, new donation strategies have become essential.

In deceased donation, the donor is dead, even though his heart might still be beating. Currently, the terms 'donation after circulatory death' (DCD) and 'donation after brain death' (DBD) are the two types of organ donation when the donor has died. The latter was formerly known as 'heart-beating donation', and implies a patient suffering from severe brain injury leading to an irreversible coma. Brain death was defined by the Ad Hoc Committee of the Harvard Medical School in 1968. ${ }^{115}$ Patients whose brain function have failed are evaluated by means of the 'brain death protocol', performed by three physicians. ${ }^{116}$ After their diagnosis, based on an apnea test, Transcranial Doppler ultrasonography (TCD) and CT angiography (CTA), organ donation can be performed.

In Europe, the term Non-heart-Beating Donor (NHBD) was used initially to describe an organ donor after circulatory arrest. This term was adopted in 1995 during the first International Workshop on Non-heart-Beating donors in Maastricht (Netherlands), leading to the so-called Maastricht Classification (Table 1.2). ${ }^{117}$ 'Awaiting cardiac or circulatory death' implies patients for whom circulatory death occurs after a planned withdrawal of life-sustaining therapies (WLST), mainly cardiorespiratory support. Cardiac arrest is expected and the medical decision of WLST is taken in a defined and multidisciplinary approach, consistent with local/national legal requirements, by the clinical team communicating with the family, when further treatment is considered futile. In the initial description, the term 'controlled' meant that the ischemia time would be known. This type of procedure was initially performed in kidney donation, but currently this is possible in lungs and liver donation as well. ${ }^{118}$

\begin{tabular}{ll}
\hline Category I. & Dead on arrival at hospital \\
Category II. & Death with Unsuccessful resuscitation \\
Category III. & Awaiting cardiac death \\
Category IV. & Cardiac arrest while brain dead \\
\hline
\end{tabular}

Table 1.2 Categories of DCD, Maastricht Classification

In 2011, a study described the situation of DCD in the council of Europe through a survey. Of 27 participating countries, only 10 confirmed any DCD activity, with a 
predominant type III DCD activity. Each had a different protocol with varying no touch periods, ranging from 5 to 20 minutes. More than 5000 transplants were performed from DCD during 2000-2008. ${ }^{119}$

\subsection{Organ donation in the Netherlands}

The first organ transplant in the Netherlands was performed in 1966, when a mother donated a kidney to her son. In the next years, both short term and long-term results of renal transplantation improved in spite of a strong increase of mean donor age and mean recipient age and an increase of co-morbidity of the recipients. Many individual factors contributed moderately to the risk of mortality after the first year. ${ }^{120}$ Introduction of HLA-DR matching and cyclosporine immunosuppression contributed to better graft survival. ${ }^{121}$

In 2018, 273 patients donated one or more organs after death (11\% more than in 2016), resulting in 911 organ donations. There were 522 living donations. On April 30, 2019, 1191 people remained on the waiting list for an organ transplant.

Currently, a so-called opt-in system is used. Organ donation can only take place with explicit consent from the donor or their surviving relatives. When becoming 18 years of age, every inhabitant receives a letter asking whether they want to become an organ donor. The Donor Registry was created in 1998, as an implementation of the Organ Donation Act from 1996. In that registry, one can choose one of the following options:

- Yes, I give consent

- No, I do not give consent

- I leave the choice to my nearest relatives

- I leave the choice to a specified person

Despite all efforts from the Ministry of Health and the Dutch Transplant Society, the number of (positively) registered people in the Donor Registry remained low. From the summer of 2020 onwards, the Netherlands will make us of a 'soft' opt-out system, referred to as an 'active donor registration' system (ADR). When people did not register, they will get a new invitation to do so, including one reminder. If one still has not registered within 6 weeks of the reminder, they will be entered in the Donor Register as having 'no objection'. This means that they agree to being a donor after their death. Family members can still stop this the donation procedure if they can show convincingly that the patient really did not want to be a donor. 


\subsection{Organ donation in Belgium}

The first deceased organ donation after brain death was performed in 1963 by $\mathrm{Pr}$ Alexandre in Leuven. ${ }^{122}$ The first version of the Belgian transplant law was published in 1986 . The legislator chose an opting-out system, making every inhabitant a possible organ donor, with the possibility to register opposed to organ donation in the national register. DCD, DBD and living donation were defined in the law, mentioning that donor death should be based upon the latest medical knowledge and techniques, being confirmed by three independent physicians. Access to the Belgian transplant waiting lists is limited to the citizens of Eurotransplant countries, or to candidates not from Belgium who have been officially registered as residents in a Eurotransplant country for a period of more than 6 months. ${ }^{123}$

The Belgian Transplantation Society (BTS) was created in 1993 as the scientific organization dealing with organ transplantation in Belgium. All 7 university hospitals and 1 peripheral hospital perform deceased and living transplantation in Belgium. A working group within the Belgian Transplantation Council has established national guidelines on DCD that have been approved by the government and the national ethical committee. ${ }^{124}$

In October 2018, only 195229 people were registered as 'opposed to organ donation' in the Belgian national registry, while 322085 people had confirmed the presumption of being an organ donor. ${ }^{125}$ Given the fact that Belgium has around 11 million inhabitants, actual refusal is a rarity. However, the registered reason for not performing organ donation after the patient has died is most often a medical contraindication or refusal by the family of the donor. ${ }^{126,127}$

Thanks to the scientific evolution in organ donation and transplantation, the quality of organ procurement as well as the quality of life in organ transplant recipients increases. At the same time, multiple countries still lack resources to perform all kinds of organ transplantation, and are limited in their possibilities to help organ donors and recipients.

\section{Organ donation after euthanasia}

Without laws on euthanasia and organ donation, it would not be possible to perform organ donation after euthanasia. Even though these laws were not written with the intention to allow for organ donation after euthanasia, elements that preclude the combination of both procedures are lacking. 


\subsection{History}

In January 2005, a female patient suffering from the consequences of a cerebrovascular accident (fixed hemiplegia, cortical blindness, spatial disorientation and dyspraxia) asked her general practitioner to undergo euthanasia. After a second physician agreed, the woman wondered whether it could also be possible to donate her organs, given the fact that she - as a Belgian inhabitant - was assumed to be an organ donor. Her physician contacted prof. Ysebaert, transplant surgeon from the University Hospital of Antwerp, who wanted to respect the patient's request, and made every effort to make her last wish possible. In less than one week, he made it possible to respond to all legal and logistic challenges that came with this very first ad hoc procedure.

In the next 5 years, 4 other Belgian patients received the possibility of organ donation after euthanasia. These patients, between 47 and 62 years of age, were suffering from multiple sclerosis, otopontocerebellar atrophy, and debilitating pain disorder from the lower legs. The Hospital Ethics Committee of the University Hospital of Antwerp cooperated to their wishes, but tried to avoid any negative publicity for the hospital. This is why these patients and their relatives could not have any media contact for at least 3 months, and the retrieved organs could not be transplanted in their own hospital.

On the ethical side both full informed consent of the donor, and a clear separation between the euthanasia procedure and the organ procurement procedure were mandated. All procedures had to be performed by senior staff members and nursing staff on a voluntary basis. Clinical diagnosis of death was performed by 3 physicians and euthanasia was performed by a neurologist and two general practitioners.

Only after these successful cases, prof. Ysebaert dared to testify about the very sensitive matter of organ donation after euthanasia. At a congress, where he presented a poster on these cases, he was verbally assaulted by the audience as they perceived people were killed in Belgium, and were now even 'used' for their organs. Nevertheless, he published about the first Belgian experiences. ${ }^{128}$

In the Netherlands, it was only in 2012 that a man in his sixties, suffering from ALS, was capable of donating both kidneys after euthanasia. The third Dutch case ever was the first one to be described in the Dutch Journal of Medicine (Nederlands Tijdschrift voor Geneeskunde). ${ }^{129}$ This article described a patient with a neurodegenerative disease who donated organs after euthanasia. 


\subsection{Local protocol}

This article was brought to the attention of the medical ethical committee of the Maastricht University Medical Center (MUMC) by prof. Van Mook. The committee decided to draft a protocol about organ donation after euthanasia, to be prepared in case a patient would ever ask for this procedure in their institution. The Erasmus Medical Center Rotterdam (Erasmus MC) initiated the same idea at the same time, which is why both hospitals decided to cooperate. This teamwork, in which numerous stakeholders were involved, resulted in a practical manual on organ donation after euthanasia. This practical manual was immediately useful in all Dutch university hospitals, and was the basis of at least twenty procedures of organ donation after euthanasia.

In 2015, all national professional organizations who could be involved in organ donation after euthanasia were invited by the Dutch Transplant Society, to debate on the content of the practical manual, and to discuss whether a national guideline was necessary. A new working group was composed, and their national guideline was presented to Minister of Health, Welfare and Sport Schippers on March 8, 2017. ${ }^{130}$ In 2016, another case report was published about a patient suffering from a progressive neurodegenerative disease who underwent organ donation after euthanasia. ${ }^{131}$

\subsection{Classification}

Organ donation after euthanasia is a donation after circulatory death (DCD) procedure, analogous to the 'Maastricht category 3'. Detry et al. published a case report in 2008 about a patient who donated her organs after physician assisted death. ${ }^{132}$ In that same year, Eurotransplant accepted organ donation after euthanasia as a form of DCD in their annual report: "Euthanasia has to be an accepted procedure in the legal framework of the donor country, and the euthanasia procedure and the determination of death after the euthanasia procedure have to be in line with national law and national practices. The euthanasia procedure and the organ retrieval as well as the organ allocation should be kept as separate as possible. Organs from donors after a euthanasia procedure shall only be allocated to patients registered on the waiting list for organ transplantation in Eurotransplant, and within Eurotransplant, in countries that accept the transplantation of this type of donor organ. In addition the possibility to indicate the acceptance of organs from donors after a euthanasia procedure should be added to the center-and patient-specific donor profiles in ENIS". ${ }^{133}$ 
In 2012, Detry included this type of patient in a separate category, in a proposal of an adapted DCD classification to better define the DCD processes, seeking to provide a better tool to compare the results of published reports and to improve current practices (Table 1.3). ${ }^{134}$ She referred to this type of DCD as 'highly controlled', since it is clear when the patient is going to die, and organ procurement can be performed quickly after determination of death.

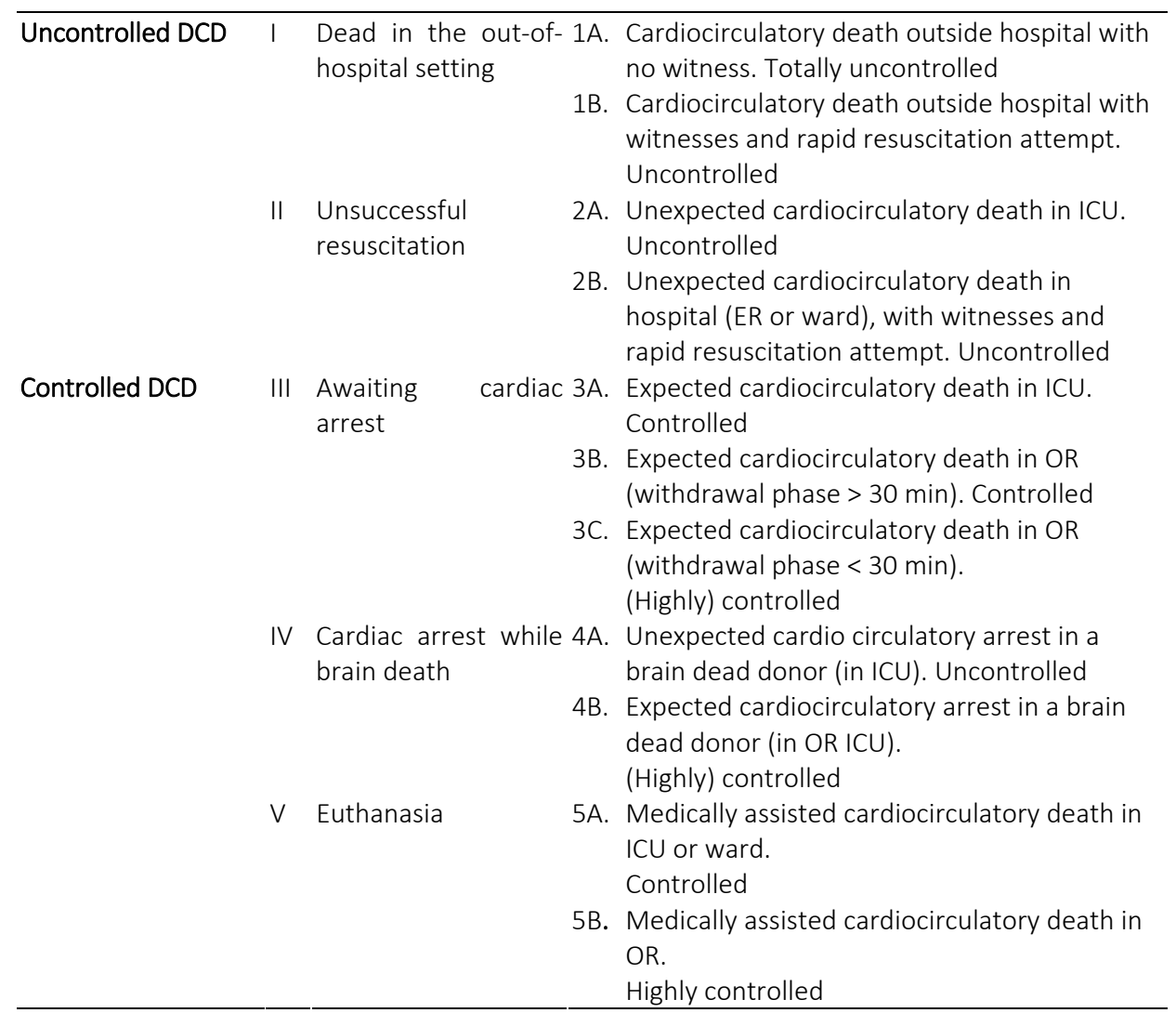

Table 1.3 Categories of DCD

The DCD definitions were refined at the 6th International Conference in Organ Donation held in Paris in 2013, to clarify the Maastricht classification, definitions and terminology used in the growing field of deceased organ donation particularly with regards to donation after circulatory death (DCD). ${ }^{118}$ The working group in Paris mentioned that legislation in some countries allows euthanasia (medically assisted CA) and subsequent organ donation described as the fifth category. 
When a patient undergoes organ donation after euthanasia, he is also able to donate his tissue, like bone, heart valve of skin. Certain contraindications however exist for patients suffering from a neurodegenerative disease, which is the patient group most fit for organ donation after euthanasia. In this thesis however, focus is put on organ donation.

In assisted suicide, patients often drink a solution that causes death within approximately 30 minutes. Organ donation after euthanasia is not possible after assisted suicide, since the dying process probably causes the patient's blood pressure and oxygen saturation to decline, which causes damage to the organs.

Organ donation after euthanasia is thus still a very recent evolution. Many ethical discussions, eg. whether to inform the patient about the possibility of organ donation after euthanasia and which preparatory investigations he should undergo still need to be held while the combined procedure will probably gain importance and popularity in the future.

\section{Scope of the thesis}

The aim of the studies presented in this thesis is to increase the scientific insight into the process of organ donation after euthanasia, and to improve awareness on the performance of the procedure and its potential impact. The following aspects were specifically studied:

- The procedure of organ donation after euthanasia

o Logistical challenges for the hospital were the procedure is performed

o Thresholds for the patient, his relatives and the medical professionals

o Legal challenges that have to be fulfilled

o Preparatory investigations that have to be performed

- Legal and ethical aspects of organ donation after euthanasia

0 Differences between the legal requirements in Belgium and the Netherlands

o What both countries can learn from each other

o Ethical consequences of the laws on organ donation and on euthanasia

- Potential of organ donation after euthanasia

o Comparing the contraindications for organ donation with euthanasia data

o Possible consequences for transplant waiting lists

- Expanding the limits of organ donation after euthanasia

o Removing organs after patients are anesthetized

o Organ donation after euthanasia in children and adults

- Results of organ donation after euthanasia

Outcome of kidney transplantation after organ donation after euthanasia 


\section{Outline of the thesis}

In this thesis, an overview of the medical, legal and ethical aspects of organ donation after euthanasia is provided. First, the current situation is described: how is organ donation after euthanasia performed? What are the differences between Belgium and the Netherlands, and what are the ethical aspects in the Netherlands? Next, the potential and outcome of organ donation after euthanasia are investigated. The thesis finishes with a view to the future: should the combined procedure be possible in children, and should 'organ donation euthanasia' be allowed?

In Chapter 2, the practical manual on organ donation after euthanasia, developed by Maastricht University Medical Center and Erasmus Medical Center Rotterdam, is discussed. All practical conditions that need to be fulfilled before a patient can donate after euthanasia are described. The legal and ethical aspects that relate to organ donation after euthanasia are discussed in Chapter 3 , in a comparison between Belgium and the Netherlands. Chapter 4 is an in-dept investigation of all legal aspects of organ donation after euthanasia in the Netherlands, focusing on the possible liabilities.

Every single patient who wants to donate his organs after euthanasia can improve and save multiple lives. To be able to make an estimation of how many patients are both willing and able to undergo organ donation after euthanasia, the Belgian euthanasia data were analyzed in Chapter 5 . With the results, policy makers can be informed, and the consequences for hospitals and health care professionals can be evaluated. Organ donation after euthanasia is only useful when the organs that are transplanted perform well in their recipient. In Chapter 6, the outcome of kidney transplantation after organ donation after euthanasia compared to other types of organ donation is reviewed.

Since euthanasia in Belgium and the Netherlands is not only possible in adults, but also in minors, and given the fact that minors can donate as well, the research question in Chapter 7 is whether minors are able to donate organs after euthanasia. The current organ donation after euthanasia procedure is a so called 'donation after circulatory death'. When a patient undergoes euthanasia and the 'no touch time' is respected, organs suffer from ischemia. Currently, this makes it impossible to donate the heart in Belgium and the Netherlands. Chapter 8 anticipates on what might be possible in the future and explores the question whether patients could be anesthetized in order to procure the organs, comparable to 'living organ donation'. 


\section{References}

1. den Hartogh G. Two kinds of physician-assisted death. Bioethics. 2017;31(9):666-673.

2. van der Maas PJ, Pijnenborg L, van Delden JJ. Changes in Dutch opinions on active euthanasia, 1966 through 1991. JAMA. 1995;273(18):1411-1414.

3. Chochinov H. Physician-assisted death in canada. Jama. 2016;315(3):253-254.

4. Emanuel EJ, Onwuteaka-Philipsen BD, Urwin JW, Cohen J. Attitudes and Practices of Euthanasia and Physician-Assisted Suicide in the United States, Canada, and Europe. Jama. 2016;316(1):79-90.

5. Verhagen E, Sauer PJ. The Groningen protocol--euthanasia in severely ill newborns. N Engl J Med. 2005;352(10):959-962.

6. Verhagen AA. The Groningen Protocol for newborn euthanasia; which way did the slippery slope tilt? J Med Ethics. 2013;39(5):293-295.

7. Wind J, Snoeijs MG, Brugman CA, et al. Prediction of time of death after withdrawal of lifesustaining treatment in potential donors after cardiac death*. Crit Care Med. 2012;40(3):766-769.

8. KNMG Richtlijn Palliatieve Sedatie [Guideline Palliative Sedation], 2009 - Accessible: www.knmg.nl/palliatieve-sedatie.

9. Dowbiggin I. A Concise History of Euthanasia: Life, Death, God, and Medicine. Rowman \& Littlefield; 2007.

10. Manning M. Euthanasia and Physician-assisted Suicide: Killing Or Caring? : Paulist Press; 1998.

11. Hamel RP, Center PR. Choosing Death: Active Euthanasia, Religion, and the Public Debate. Trinity Press International; 1991.

12. Orfali R. Death with Dignity: The Case for Legalizing Physician-assisted Dying and Euthanasia. Mill City Press; 2011.

13. Grodin MA, Miller EL, Kelly JI. The Nazi Physicians as Leaders in Eugenics and "Euthanasia": Lessons for Today. Am J Public Health. 2018;108(1):53-57.

14. Oehmichen $\mathrm{M}$, Meissner $\mathrm{C}$. Life shortening and physician assistance in dying: euthanasia from the viewpoint of German legal medicine. Gerontology. 2000;46(4):212-218.

15. Michalsen A, Reinhart K. "Euthanasia": A confusing term, abused under the Nazi regime and misused in present end-of-life debate. Intensive Care Med. 2006;32(9):1304-1310.

16. Jox RJ, Horn RJ, Huxtable R. European perspectives on ethics and law in end-of-life care. Handbook of Clinical Neurology. 2013;118:155-165.

17. European Court of Human Rights: case of Pretty v. the United Kingdom. Issues Law Med. 2002;18(1):67-89.

18. Diane Pretty dies in the way she always feared, The Telegraph, 13 May 2002 - Accessible: https://www.telegraph.co.uk/news/uknews/1394038/Diane-Pretty-dies-in-the-way-she-alwaysfeared.html.

19. Singer P. Ms B and Diane Pretty: a commentary. J Med Ethics. 2002;28(4):234-235.

20. European Court of Human Rights Factsheet: End of life and the European Convention on Human Rights, January 2018 - http://www.echr.coe.int/Documents/FS_Euthanasia_ENG.pdf.

21. Cohen J, Marcoux I, Bilsen J, Deboosere P, van der Wal G, Deliens L. Trends in acceptance of euthanasia among the general public in 12 European countries (1981-1999). Eur J Public Health. 2006;16(6):663-669.

22. Cohen J, Van Landeghem P, Carpentier N, Deliens L. Different trends in euthanasia acceptance across Europe. A study of 13 western and 10 central and eastern European countries, 1981-2008. Eur J Public Health. 2013;23(3):378-380.

23. Cohen J, Van Landeghem P, Carpentier N, Deliens L. Public acceptance of euthanasia in Europe: a survey study in 47 countries. Int J Public Health. 2014;59(1):143-156.

24. McDougall JF, Gorman M. Euthanasia: A Reference Handbook. ABC-CLIO; 2008.

25. Fairman RP. Withdrawing life-sustaining treatment. Lessons from Nancy Cruzan. Arch Intern Med. 1992;152(1):25-27.

26. Mueller PS. The Terri Schiavo saga: ethical and legal aspects and implications for clinicians. Pol Arch Med Wewn. 2009;119(9):574-581. 
27. Rietjens JAC, van der Maas PJ, Onwuteaka-Philipsen BD, van Delden JJM, van der Heide A. Two Decades of Research on Euthanasia from the Netherlands. What Have We Learnt and What Questions Remain? J Bioeth Inq. 2009;6(3):271-283.

28. Weyers H. Euthanasie: het proces van rechtsverandering. Amsterdam University Press; 2004.

29. Griffiths, J., A. Bood, and H. Weyers. 1998. Euthanasia and law in the Netherlands. Amsterdam: Amsterdam University Press.

30. Schoonheim PL. The right to die: the euthanasia discussion in The Netherlands. J Cancer Educ. 1989;4(2):109-112.

31. Final report of the Netherlands State Commission on Euthanasia: an English summary. Bioethics. 1987;1(2):163-174.

32. Onwuteaka-Philipsen BD, Muller MT, van der Wal G, van Eijk JT, Ribbe MW. Attitudes of Dutch general practitioners and nursing home physicians to active voluntary euthanasia and physicianassisted suicide. Arch Fam Med. 1995;4(11):951-955.

33. de Haan J. The new Dutch law on euthanasia. Medical law review. 2002;10(1):57-75.

35. Legemaate J. The Dutch Euthanasia Act and related issues. J Law Med. 2004;11(3):312-323.

36. Burial and Cremation Act (Netherlands), Article 7 sub 2, March 7,1991 [Wet op de lijkbezorging]. Het Jaarverslag 2018 is vandaag verschenen, 11 April 2019, accessible: https://www.euthanasiecommissie.nl/actueel/nieuws/2019/april/11/jaarverslag-2018.

Cohen-Almagor R. Euthanasia policy and practice in Belgium: critical observations and suggestions for improvement. Issues Law Med. 2009;24(3):187-218.

Deliens L, Mortier F, Bilsen J, et al. End-of-life decisions in medical practice in Flanders, Belgium: a nationwide survey. Lancet. 2000;356(9244):1806-1811.

van der Heide A, Deliens L, Faisst K, et al. End-of-life
descriptive study. Lancet. 2003;362(9381):345-350.

40. Saad TC. Euthanasia in Belgium: legal, historical and political review. Issues Law Med. 2017;32(2):183-204.

41. John Griffiths, Heleen Weyers, Marice Adams, Euthanasia and Law in Europe, Hart Publishing, Oxford and Portland, Oregon, 2008.

42. Belgian Advisory Committee on Bioethics, Opinion no. 1 of 12 May 1997 concerning the adivsability of a legal regulation on euthanasia - Accessible: https://www.health.belgium.be/ sites/default/files/uploads/fields/fpshealth_theme_file/opinion_1_web.pdf.

43. Leen De Vleesschauwer, De Belgische euthanasiewetgeving: Een literatuurstudie, Universiteit Gent, Academiejaar 2004-2005 - Accessible: https://lib.ugent.be/fulltxt/RUG01/000/921/ 250/RUG01-000921250_2010_0001_AC.pdf.

44. Art. 15 Euthanasia Act (Belgium), May 28, 2002 [Wet betreffende de euthanasie]. In.

45. Dierickx S, Deliens L, Cohen J, Chambaere K. Euthanasia in Belgium: trends in reported cases between 2003 and 2013. CMAJ. 2016;188(16):E407-e414.

46. Dierickx S, Deliens L, Cohen J, Chambaere K. Comparison of the Expression and Granting of Requests for Euthanasia in Belgium in 2007 vs 2013. JAMA Int Med. 2015;175(10):1703-1706.

47. Van Raemdonck D, Neyrinck A. Euthanasia Patients Should Be Accepted as Organ Donors in States With Existing Legislation. Ann Thorac Surg. 2016;102(6):1787-1788.

48. Dyer O, White C, Garcia Rada A. Assisted dying: law and practice around the world. BMJ (Clinical research ed). 2015;351:h4481.

49. Roehr B. Assisted dying in US and Canada: controversy subsides after legalisation. BMJ (Clinical research ed). 2018;360:k503.

50. Kane L. Medscape ethics report 2014. Part 1: life, death and pain. 16 Dec 2014 - Accessible: www.medscape.com/features/slideshow/public/ethics2014-part1\#2.

51. Snyder Sulmasy L, Mueller PS. Ethics and the Legalization of Physician-Assisted Suicide: An American College of Physicians Position Paper. Ann Intern Med. 2017;167(8):576-578.

52. Kussmaul WG, 3rd. The Slippery Slope of Legalization of Physician-Assisted Suicide. Ann Intern Med. 2017;167(8):595-596.

53. Watson R. Luxembourg is to allow euthanasia from 1 April. BMJ (Clinical research ed). 2009;338:b1248. 
54. Ministry of Health, Ministry of Social Security (Luxembourg). Euthanasia and assisted suicide: 25 questions, 25 answers. June 2010 - Accessible: www.sante.public.lu/publications/sante-fil-vie/finvie/euthanasie-assistance-suicide-25-questions-reponses/euthanasie-assistance-suicide-25questions-reponses-en.pdf.

55. Ministerio de Salud y Protección Social [Ministry of Health and Social Protection]. Resolución número 1216 de 2015 (en relación con las directrices para la organización y funcionamiento de los Comités para hacer efectivo el derecho a morir con dignidad). [Resolution no 1216 of 2015 (in relation to the guidelines for the organization and functioning of the Committees to implement the right to die with dignity).] 20 April 2015 - Accessible: www.minsalud.gov.co/ Normatividad_Nuevo/Resoluci\%C3\%B3n\%201216\%20de\%202015.pdf.

56. Bill C-14: An Act to amend the Criminal Code and to make related amendments to other Acts (medical assistance in dying), June 17, 2016 - Accessible: http://www.parl.ca/DocumentViewer/ en/42-1/bill/C-14/royal-assent. In.

57. Carter v. Canada (Attorney General). 2015 SCC 5: Supreme Court of Canada, 2015 - Accessible: https://scc-csc.lexum.com/scc-csc/scc-csc/en/item/14637/index.do.

58. Chochinov HM, Frazee C. Finding a balance: Canada's law on medical assistance in dying. Lancet. 2016;388(10044):543-545.

59. Li M, Watt S, Escaf M, et al. Medical Assistance in Dying - Implementing a Hospital-Based Program in Canada. N Engl J Med. 2017;376(21):2082-2088.

60. LégisQuébec, Act respecting end-of-life care - Accessible: http://legisquebec.gouv.qc.ca/en/ShowDoc/cs/S-32.0001. In.

61. Allard J, Fortin MC. Organ donation after medical assistance in dying or cessation of life-sustaining treatment requested by conscious patients: the Canadian context. J Med Ethics. 2017;43(9): 601-605.

62. Ball IM, Sibbald R, Truog RD. Voluntary Euthanasia - Implications for Organ Donation. N Engl J Med. 2018;379(10):909-911.

63. Euthanasia comes to the fore in Spanish election campaign after 70-year-old's arrest for helping wife die, The Telegraph, 5 April 2019, Accessible: https://www.telegraph.co.uk/news/2019/ 04/05/euthanasia-comes-fore-spanish-election-campaign-70-year-olds/.

64. Spain's Socialists moving closer to coalition government with Podemos, El Pais, 23 May 2019, Accessible: https://elpais.com/elpais/2019/05/23/inenglish/1558595100_603812.html.

65. Rada AG. Assisted dying: case of man who helped his wife to die reignites Spain's euthanasia debate. BMJ (Clinical research ed). 2019;365:I1764.

66. Lo B. Beyond Legalization - Dilemmas Physicians Confront Regarding Aid in Dying. N Engl J Med. 2018;378(22):2060-2062.

67. Oregons Death With Dignity Act - Accessible: http://public.health.oregon.gov/ ProviderPartnerResources/EvaluationResearch/DeathwithDignityAct/Pages/ar-index.aspx.

68. Death with Dignity Act Annual Report 2017, Released February 9, 2018 - Accessible: http://www.oregon.gov/oha/PH/PROVIDERPARTNERRESOURCES/EVALUATIONRESEARCH/DEATH WITHDIGNITYACT/Documents/year20.pdf.

69. Vermont Act Relating to patient choice and control at end of life - Accessible: http://www.leg.state.vt.us/docs/2014/Acts/ACT039.pdf. In.

70. Vermont Department of Health, Report Concerning Patient Choice at the End of Life, January 15, 2018 - Accessible: https://legislature.vermont.gov/assets/Legislative-Reports/2018-PatientChoice-Legislative-Report-12-14-17.pdf.

71. Vermont Medical Society Policy on End-of-life-Care As adopted at the VMS Annual Meeting on November 4, 2017 - Accessible: http://www.vtmd.org/sites/default/files/2017End-of-LifeCare.pdf.

72. Latham SR. "Aid in dying" in the courts. Hastings Cent Rep. 2015;45(3):11-12.

73. Associated Press, New Mexico Court of Appeals strikes down right-to-die ruling, August 11, 2015 Accessible: https://www.washingtontimes.com/news/2015/aug/11/new-mexico-court-of-appealsstrikes-down-right-to-/. 
74. House Bill 171, 53rd legislature, State of New Mexico, First Session 2017, removing criminal liability for attending health care providers who provde assistance pursuant to the end of life options act - Accessible: https://www.nmlegis.gov/Sessions/17\%20Regular/bills/house/ HB0171.pdf. In.

75. California Assembly Bill No. 15, An act to add and repeal Part 1.85 (commencing with Section 443) of Division 1 of the Health and Safety Code, relating to end of life, Approved by Governor October 05, $2015 \quad$ - Accessible: https://leginfo.legislature.ca.gov/faces/billNavClient.xhtml?bill id $=201520162 \mathrm{AB} 15$.

76. California Department of Public Health, California End of Life Option Act, 2016 data report Accessible: $\quad$ https://www.cdph.ca.gov/Programs/CHSI/CDPH\%20Document\%20Library/ CDPH\%20End\%20of\%20Life\%200ption\%20Act\%20Report\%20-ADA.pdf.

77. Susan Scutti, California judge overturns End of Life Option Law, CNN Health, May 16, 2018 Accessible: $\quad$ https://edition.cnn.com/2018/05/16/health/california-assisted-suicide-lawoverturned/index.html.

78. Council of the District of Columbia, D.C. Act 21-577, Death with Dignity Act of 2016 - Accessible: https://dchealth.dc.gov/sites/default/files/dc/sites/doh/page_content/attachments/Death\%20Wi th\%20Dignity\%20Act.FINAL_.pdf. In.

79. House Of Representatives, Twenty-Ninth Legislature, 2018, State of Hawaii, HB 2739 HD1 Accessible: https://www.capitol.hawaii.gov/session2018/bills/HB2739_HD1_.HTM. In.

80. Death With Dignity, Hawaii - Accessible: https://www.deathwithdignity.org/states/hawaii/.

81. Washington, Initiatieve Measure No. 1000, The Washington Death with Dignity Act - Accessible: https://www.sos.wa.gov//elections/initiatives/text/i1000.pdf. In.

82. Washington State Department of Health, Death with Dignity Act Report, March 2018 - Accessible: https://www.doh.wa.gov/Portals/1/Documents/Pubs/422-109-DeathWithDignityAct2017.pdf.

83. Colorado End-of-Life Options Act, (Formerly Proposition 106 and Initiative 145) - Accessible: http://www.sos.state.co.us/pubs/elections/Initiatives/titleBoard/filings/2015-2016/145Final.pdf.

84. Colorado Department of Public Health and Environment, Colorado End-of-Life Options Act, Year One, 2017 Data summary - Accessible: https://www.colorado.gov/pacific/sites/default/files/ CHED_VS_Report_Colorado-End-of-Life-Options-Act-Year-One-2017-Data-Summary_0218.pdf.

85. Orentlicher D, Pope TM, Rich BA. The changing legal climate for physician aid in dying. JAMA. 2014;311(19):1961-1962.

86. Ganzini L, Goy ER, Dobscha SK, Prigerson H. Mental health outcomes of family members of Oregonians who request physician aid in dying. J Pain Symptom Manage. 2009;38(6):807-815.

87. Kissane DW, Street A, Nitschke P. Seven deaths in Darwin: case studies under the Rights of the Terminally III Act, Northern Territory, Australia. Lancet. 1998;352(9134):1097-1102.

88. Parliament of Victoria, Department Of Parliamentary Services, Research Note: Voluntary Assisted Dying Bill 2017 - Accessible: https://www.parliament.vic.gov.au/publications/researchpapers/send/36-research-papers/13834-voluntary-assisted-dying-bill-2017.

89. O'Connor MM, Hunt RW, Gardner J, et al. Documenting the process of developing the Victorian voluntary assisted dying legislation. Aust Health Rev. 2018;42(6):621-626.

90. Gauthier S, Mausbach J, Reisch T, Bartsch C. Suicide tourism: a pilot study on the Swiss phenomenon. J Med Ethics. 2015;41(8):611-617.

91. Steck N, Junker C, Zwahlen M. Increase in assisted suicide in Switzerland: did the socioeconomic predictors change? Results from the Swiss National Cohort. 2018;8(4):e020992.

92. Assisted Dying Bill (draft). June 2015 - Accessible: https://publications.parliament.uk/pa/ bills/cbill/2015-2016/0007/cbill_2015-20160007_en_1.htm.

93. James Gallagher, Assisted Dying Bill: MPs reject 'right to die' law, 11 September 2015, BBC News Accessible: http://www.bbc.com/news/health-34208624.

94. Wise J. Royal college of physicians still opposes change in law on assisted dying. BMJ (Clinical research ed). 2014;349:g7335.

95. DW, German Federal Court rules patients should have access to life-ending drugs, March 2 2017, accessible: https://www.dw.com/en/german-federal-court-rules-patients-should-have-access-tolife-ending-drugs/a-37790952.

96. DW, Top German court to decide legality of assisted suicide, April 15 2019, accessible: https://www.dw.com/en/top-german-court-to-decide-legality-of-assisted-suicide/a-48309051. 
97. Bundesgerichtshof entscheidet über Haftung wegen Lebenserhaltung durch künstliche Ernährung, 02 April 2019, Accessible: https://www.bundesgerichtshof.de/SharedDocs/Pressemitteilungen/ DE/2019/2019040.html?nn=10690868.

98. Quinn KL, Detsky AS. Medical Assistance in Dying: Our Lessons LearnedMedical Assistance in DyingPerspective. JAMA Int Med. 2017;177(9):1251-1252.

99. U.S. Government Information on Organ Donation and Transplantation, Timeline of historical events and significant milestones - Accessible: https://organdonor.gov/about/facts-terms/ history.html.

100. Barker CF, Markmann JF. Historical Overview of Transplantation. Cold Spring Harbor Perspectives in Medicine. 2013;3(4).

101. Fishman JA, Rubin RH. Infection in organ-transplant recipients. N Engl J Med. 1998;338(24): 1741-1751.

102. Barry JM. Successful homotransplantation of the human kidney between identical twins. 1956. J Urol. 2002;167(2 Pt 2):830.

103. Murray JE, Tilney NL, Wilson RE. Renal transplantation: a twenty-five year experience. Ann Surg. 1976;184(5):565-573.

104. W. BR, G. DCL, V. MP, B. G, R. FL, E. ST. The First Report of Orthotopic Liver Transplantation in the Western World. Am J Transplant. 2012;12(6):1385-1387.

105. Zarrinpar A, Busuttil RW. Liver transplantation: past, present and future. Nat Rev Gastroenterol Hepatol. 2013;10(7):434-440.

106. Starzl TE, Marchioro TL, Kaulla KNV, Hermann G, Brittain RS, Waddell WR. Homotransplantation of the liver in humans. Surg Gynecol Obstet. 1963;117:659-676.

107. Starzl TE, Groth CG, Brettschneider L, et al. Orthotopic homotransplantation of the human liver. Ann Surg. 1968;168(3):392-415.

108. Metras H 1950. Note preliminarie sur la greffe total du poumon chez le chien. CR Acad Sci III 231: 1176-1177.

109. Venuta F, Van Raemdonck D. History of lung transplantation. J Thorac Dis. 2017;9(12):5458-5471.

110. Yeung JC, Keshavjee S. Overview of Clinical Lung Transplantation. Cold Spring Harbor Perspectives in Medicine. 2014;4(1).

111. Hardy JD, Webb WR, Dalton ML, Jr., Walker GR, Jr. Lung homotransplantation in man. JAMA. 1963;186:1065-1074.

112. Derom F, Barbier F, Ringoir S, et al. Ten-month survival after lung homotransplantation in man. $J$ Thorac Cardiovasc Surg. 1971;61(6):835-846.

113. Hesse UJ, de Hemptinne B, Derom F. History of transplantation at the University Hospital of Ghent Belgium 1965-2002. Acta Chir Belg. 2003;103(3 Spec No):28-31.

114. Brink JG, Hassoulas J. The first human heart transplant and further advances in cardiac transplantation at Groote Schuur Hospital and the University of Cape Town. Cardiovasc J Afr. 2009;20(1):31-35.

115. A definition of irreversible coma. Report of the Ad Hoc Committee of the Harvard Medical School to Examine the Definition of Brain Death. JAMA. 1968;205(6):337-340.

116. Health Council of the Netherlands. Brain Death Protocol. The Hague: Health Council of the Netherlands, 2006; publication no. 2006/04E. ISBN 978-90-5549-886-4.

117. Kootstra G, Daemen JH, Oomen AP. Categories of non-heart-beating donors. Transplant Proc. 1995;27(5):2893-2894.

118. Thuong M, Ruiz A, Evrard P, et al. New classification of donation after circulatory death donors definitions and terminology. Transpl Int. 2016;29(7):749-759.

119. Domínguez-Gil B, Haase-Kromwijk B, Van Leiden $\mathrm{H}$, et al. Current situation of donation after circulatory death in European countries. Transpl Int. 2011;24(7):676-686.

120. Arend SM, Mallat MJ, Westendorp RJ, van der Woude FJ, van Es LA. Patient survival after renal transplantation; more than 25 years follow-up. Nephrol Dial Transplant. 1997;12(8):1672-1679.

121. van Saase JL, Mallat MJ, van der Woude FJ, van Bockel JH, van Es LA. [Results of kidney transplantation in Leiden, 1966-1994, and prognostic factors]. Ned Tijdschr Geneeskd. 1996;140(15):827-832.

122. Squifflet JP. The History of Transplantation at the Catholic University of Louvain-Belgium 19632003. Acta Chir Belg. 2003;103 Suppl 1:10-20. 
123. Detry O, Van Deynse D, Van Vlierberghe H, Pirenne J. Organ Procurement and Transplantation in Belgium. Transplantation. 2017;101(9):1953-1955.

124. Belgian Transplantation Council, Belgian Transplantation Society. Opinion no. 63-draft protocol "Donation after Circulatory Death" (DCD). Service Public Federal Web site. https://www.health.belgium.be/fr/node/28836. Published online October 12, 2015.

125. Section Belgian transplant coordinators, Donor \& Transplant statistics, BTS 2016, Accessible: https://www.health.belgium.be/sites/default/files/uploads/fields/fpshealth_theme_file/bts__donor_and_transplant_statistics_2016.pdf.

126. Shaw D. We should not let families stop organ donation from their dead relatives. BMJ (Clinical research ed). 2012;345:e5275.

127. Shaw D, Georgieva D, Haase B, et al. Family Over Rules? An Ethical Analysis of Allowing Families to Overrule Donation Intentions. Transplantation. 2017;101(3):482-487.

128. Ysebaert D, Van Beeumen G, De Greef K, et al. Organ procurement after euthanasia: Belgian experience. Transplant Proc. 2009;41(2):585-586.

129. van Dijk G UF, Hamers R. Orgaandonatie na euthanasie bij een patiënt met een neurodegeneratieve aandoening. Ned Tijdschr Geneeskd. 2013;(157):A6548.

130. Mulder H, Olthuis G, Siebelink M, Gerritsen R, van Heurn E. [Guideline 'Organ donation following euthanasia"]. Ned Tijdschr Geneeskd. 2017;161(0):D2135.

131. van Wijngaarden AK, van Westerloo DJ, Ringers J. Organ Donation After Euthanasia in the Netherlands: A Case Report. Transplant Proc. 2016;48(9):3061-3063.

132. Detry $\mathrm{O}$, Laureys $\mathrm{S}$, Faymonville $\mathrm{ME}$, et al. Organ donation after physician-assisted death. Transplant Int. 2008;21(9):915.

133. Eurotransplant, Annual Report 2008, REC01.08 p. 24.

134. Detry O, Le Dinh $\mathrm{H}$, Noterdaeme $\mathrm{T}$, et al. Categories of donation after cardiocirculatory death. Transplant Proc. 2012;44(5):1189-1195. 


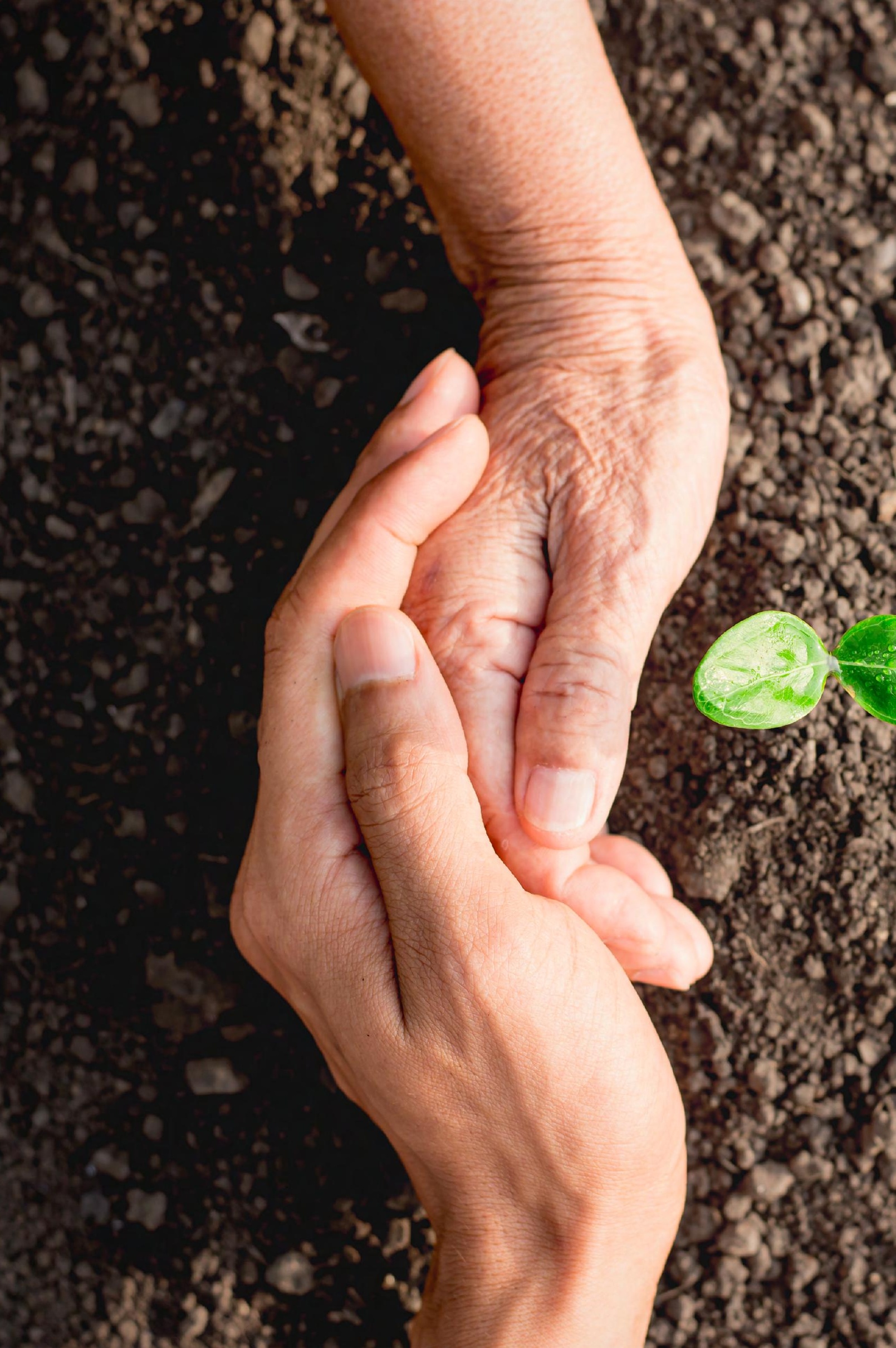




\section{ghaper}

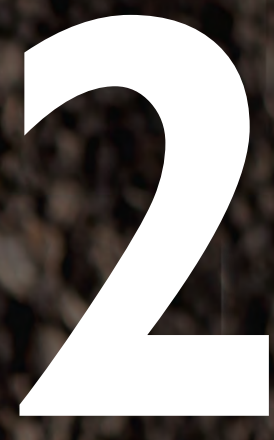

\section{Organ donation after euthanasia: A Dutch practical manual}

Jan Bollen, Wim de Jongh, Hanneke Hagenaars, Gert van Dijk, Rankie ten Hoopen, Dirk Ysebaert, Jan Jjzermans, Ernst van Heurn, Walther van Mook American Journal of Transplantation 2016;16(7):1967-1972 


\section{Abstract}

Many physicians and patients do not realize that it is legally and medically possible to donate organs after euthanasia. Even though this is not common practice, often limited by the patient's underlying pathologies, the combination of euthanasia and organ donation has been practiced in both Belgium and the Netherlands. In anticipation of patient's requests for organ donation after euthanasia, and contributing to awareness of the possibility of this combination among general practitioners and medical specialists, the Maastricht University Medical Center (MUMC), together with the Erasmus University Medical Center Rotterdam, have developed a multidisciplinary practical manual in which steps to organize this combined procedure are described and explained. This practical manual lists the various criteria to fulfill, and the rules and regulations that the different stakeholders involved, e.g. the patient, the performing physician, the transplant coordinator, the municipal coroner and the main treating physician need to comply with to meet all due diligence requirements. 


\section{Introduction}

In September 2013, an article addressing organ donation after active euthanasia was published in the Dutch Journal of Medicine. ${ }^{1}$ A patient suffering from a progressive neurodegenerative disease was able to donate his liver and both kidneys. Organ donation after euthanasia has been described earlier with excellent transplant outcome. $^{2,3}$

The current developments necessitate the creation of a practical manual addressing the combination of both procedures, because of the unique and complex ethical issues, together with the carefulness that is needed. This practical manual can be used as a framework for hospitals that wish to facilitate such combined procedures. The essential components of the practical manual, developed by the collaborative efforts of the Maastricht University Medical Center and the Erasmus Medical University Medical Center Rotterdam are successively discussed in the sections below.

Although the manual addresses euthanasia and organ donation in the Netherlands, many of the issues raised and discussed may be similar or comparable in any country allowing organ donation in the setting of euthanasia.

\section{Legal issues regarding euthanasia and organ donation}

Physicians are allowed to carry out euthanasia, if the due diligence requirements of the Euthanasia Act are fulfilled. ${ }^{4}$ If a patient requests to undergo euthanasia and subsequently donate his organs, his physician has to investigate whether the due diligence requirements for euthanasia are met before initiating the process of preparation for organ donation. ${ }^{5}$ If there is a clear contraindication for organ donation, the physician has to discuss this with the patient without delay.

The patient needs to request euthanasia voluntarily and well considered, he must be hopelessly and unbearably suffering, well informed, and other reasonable solutions for this suffering must be unavailable. This does not mean the patient has to be terminally suffering from a condition that will cause him to die within a predefined, relatively short time frame. Furthermore, a second independent physician has to be consulted, and the euthanasia procedure should be performed according to the latest standard. 
Euthanasia in minors of at least 12 years of age is allowed, even though this has only occurred less than ten times. The suffering in these children mainly resulted from malignancies, which makes organ donation nearly always impossible. Therefore, this practical manual focuses on adults. After the patient has died, the Dutch Burial and Cremation Act requires the municipal coroner to be notified, since - from a legal perspective - euthanasia results in a non-natural death. The municipal coroner is obliged to inform the public prosecutor and the regional euthanasia review committee. ${ }^{6}$ since the euthanasia procedure causes the patient to die from cardiac arrest, only donation after circulatory death (DCD) is possible. ${ }^{7}$

\section{Ethical issues regarding euthanasia and organ donation}

Although the combination of euthanasia and organ donation has already been performed, the practice remains ethically questionable.

\section{Motivation of the patient}

It would be preferable to strictly separate both procedures, avoiding the ill patient being persuaded to undergo euthanasia. The treating physician should thus investigate whether the patient is prompted to undergo euthanasia simply because this gives him the possibility to donate his organs. On the other hand, one could ask why it is necessary to prevent this altruistic act? If a patient fulfills the due diligence criteria for euthanasia, the fact that he wants to undergo euthanasia because this allows him to donate his organs, should not hamper the procedure.

It can be hypothesized that people who have been confronted with the poor quality of life of patients on the transplant waiting list might be more willing to be an organ donor. Nevertheless, allocation after DCD is done by Eurotransplant, because of which the donor is not able to choose the recipient. Living donation before euthanasia is theoretically possible. In case of HLA matching, this would also give the donor the possibility to choose a relative as recipient. It is however unethical to compel a suffering person to undergo surgery for altruistic living donation programs, in order to optimize the quality and allocation of the donated organ. 


\section{Heart beating donation}

Some organ donors expressed the wish to donate all their organs, including their heart. ${ }^{8}$ A theoretical possibility would be to perform euthanasia by removing the heart under general anesthesia. The donated organs do not sustain ischemia, which improves their quality. The 'dead donor rule', as well as the current Dutch Euthanasia Act currently however does not allow such 'heart beating euthanasia donation procedure'. ${ }^{9}$ Next to this legal threshold, practice has learned that some relatives insist on seeing the patient die before he or she is being brought to the operating room.

\section{Is the physician obliged to mention organ donation after euthanasia?}

What if a physician is confronted with a patient who fulfills all due diligence requirements for euthanasia, lacks contraindications for organ donation, but does not raise the issue of organ donation himself? By mentioning the possibility of organ donation after euthanasia, the physician appeals to the patient's right to selfdetermination, and creates awareness and mindset regarding this perhaps unknown possibility. It could be comforting to know that he or she is able to help people survive and improve their quality of life. On the other hand, when a patient is suffering so severely that he requests to undergo euthanasia, it may be inappropriate to discuss organ donation. Would the physician not be adding burden resulting in more suffering and worrying for the patient and his relatives?

The treating physician who often has a long lasting relationship of trust with the patient, is usually the preferred person to raise the issue of organ donation after euthanasia. If he decides to do this, the patient's previously documented preferences regarding organ donation should be checked in the Dutch Donor Registry, as required by Dutch law. This registration could guide the physician in the dilemma whether or not to discuss this subject with his patient. If the patient is not registered, discussing organ donation is theoretically still an option.

\section{Informing the donor and the recipient}

In the past, donors have asked who would become the recipients of the different organs. Officially, it is not allowed to convey this information for reasons of privacy. The answer might also put additional pressure on the donor to continue the process, even when having thoughts about withdrawal from the donation process. It could also create extra stress if the patient is informed that there is no suitable recipient for an organ. 
According to Eurotransplant, a patient on the waiting list should have the possibility to indicate the acceptance of organs from donors after a euthanasia procedure. ${ }^{10}$ This could however create moral problems for the recipient, who might be a strict opponent of euthanasia, but still wants to survive by accepting this organ.

As illustrated by the previous sections, many ethical questions arise in the combination of euthanasia and organ donation. In any case, this combination makes it possible for the conscious patient himself to decide whether, how and when he will donate his organs, which is impossible in all other DCD procedures.

\section{Content of the practical manual}

What practical steps should a general practitioner or medical specialist take when a patient requests euthanasia, but also expresses his wish to donate his organs, in the absence of contraindications for donation? All consecutive steps can be found in Figure 2.1.

\section{Euthanasia}

The patient's euthanasia request is often well considered, and therefore the issue is generally not raised unexpectedly. It will result from a process of increasing insight and knowledge during his illness, after a constant dialogue between the treating physician and the patient. Different options will be discussed, like palliative sedation, pain relief, and going to a hospice.

It is possible that the option of organ donation is raised in this process, even before the issue of euthanasia has been discussed. In this case, the physician should state that the due diligence requirements for euthanasia have to be considered and complied with, before the issue of organ donation can be discussed. After the second physician's consultation, the treating physician can agree with the euthanasia request. He then becomes the 'performing physician' who has a pivotal role in the euthanasia procedure. 


\section{FLOWCHART}

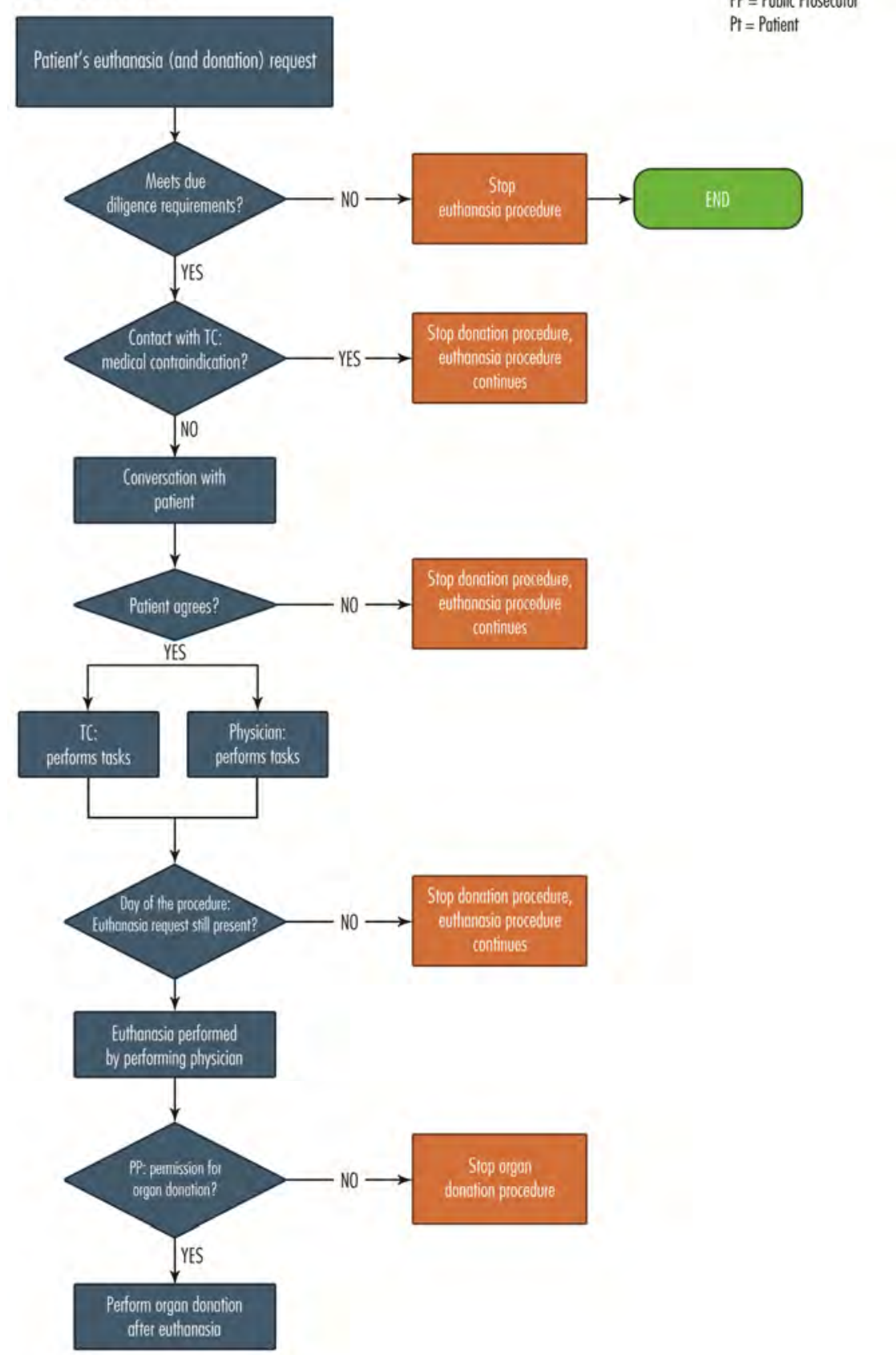

$\mathrm{TC}=$ Transplant Coordinator

$P P=$ Public Prosecutor

$\mathrm{Pt}=$ Patient

Figure 2.1 Flowchart of the organ donation after euthanasia procedure 


\section{Organ donation}

If the patient wishes to become an organ donor, the performing physician verifies whether the patient is registered as an organ donor. If this is not the case, the patient has to provide an advance directive. After this administrative requirement, the performing physician contacts the transplant coordinator.

\section{Transplant coordinator}

The patient then needs to give the transplant coordinator permission to review his medical files for contraindications for organ donation. If the patient is a suitable potential donor, a meeting between the patient and the performing physician is arranged during which practical and procedural issues will be clarified (the house call). Current practice demonstrates that the presence of a transplant coordinator during the house call is appreciated by the performing physician and the patient.

During the house call, at least two important issues are raised; necessity of additional diagnostic testing, and the need for an in-hospital euthanasia (as opposed to a euthanasia procedure at home).

\section{Additional diagnostic tests}

Even though Dutch law states that diagnostic tests can only be performed when this benefits the patient, the Act on Organ Donation allows the transplant coordinator to perform these tests when it is clear that the patient will die within a limited period of time. Depending on the results, the transplant coordinator decides which organs can be donated. The patient is informed immediately when a contraindication is identified.

A standard blood- and urine sample is collected during the house call (see note). ${ }^{11}$ Depending on the organs the patient wants to donate, additional tests are necessary to exclude apparent contraindications. These can be performed in the hospital before admission or on the day of euthanasia, depending on the patient's wish. Based on the results, Eurotransplant searches suitable recipients. ${ }^{12}$ It is nevertheless possible that a contraindication against organ donation is discovered during surgery.

\section{In-hospital procedure}

After the euthanasia procedure the deceased is transported to the operating room as fast as possible. This is important information for the relatives; they will not be able to 
have a quiet, personal moment with the deceased, since the period of time between death and retrieval of the organs needs to be as short as possible. Every minute of delay causes the quality of the organs to decline, which may even result in an impossibility to donate due to ischemia. Before the procedure, preferably during the house call, the relatives are extensively informed that they need to say goodbye before the euthanasia drugs are administered.

It is imperative to discuss what to do if the patient's condition deteriorates in the days preceding the day of the procedure. If necessary, a new medical evaluation will be performed to determine if the organs are still eligible for donation. Physicians as well as case law have pointed out that a patient who becomes unconscious, is most often judged not to be suffering, which would imply that the necessary criteria for euthanasia are not met anymore. ${ }^{13}$ This seems paradoxal, since performing euthanasia might be more bearable to the patient if he would be unconscious. Donation after natural circulatory death is an alternative option for organ donation in this context. Extensive discussion of this procedure is beyond the scope of this article.

\section{Influence of relatives}

Presence of the relatives during the euthanasia procedure and/or the house call is possible at the discretion of the patient. It is neither necessary to obtain consent from the relatives, nor are they theoretically able to veto the procedure. This again raises ethical questions, whether it is ethical for the family members to have their own preferences prevail over those of the patient and whether their own interests and emotions should be discussed and taken into account. If they oppose to the procedure, the patient may feel forced to withdraw, which seems to contradict the patient's right for self-determination.

\section{Preparatory measures}

After the house call, the combined euthanasia and organ donation procedure is organized. The patient, the performing physician and the transplant coordinator, in close communication with the medical coordinator of the operating room, will decide on a suitable date. If necessary, the performing physician orders an ambulance for transportation to the hospital. 
Even though several preparatory meetings with all stakeholders to discuss this matter in general have already been held, any potential moral reservations of the staff involved in the procedure will be respected. For obvious reasons, the hospital will only deploy staff who are willing and able to participate in this procedure.

If the performing physician is not an employee of the hospital (but a general practitioner or medical specialist from another institution), he needs to sign a statement declaring that the due diligence requirements in his opinion have been fulfilled, and that euthanasia will be performed according to the latest standards, since the hospital is formally responsible for the procedure as well. ${ }^{14}$

The preferred pathway in view of the fact that euthanasia is a non-natural death, is that the transplant coordinator pre-informs the municipal coroner (forensic physician), who, after examination of the patient's medical chart, informs the public prosecutor about this procedure and the scheduled date. The public prosecutor will then be able to grant permission to use the body for organ donation, so that no time is lost after the patient has died. ${ }^{15}$ This approach optimizes the process of organ donation while the patient's final wish for organ donation is respected, reduces the period of time between death and organ procurement, and improves the quality of the organs after transplantation.

If requested by the patient or his relatives, staff members of the departments of mental health and/or social welfare will be present during and after euthanasia.

\section{Day of the procedure}

The patient's arrival time in the hospital depends on the organs to be donated. In case of lung donation, an additional surgical team is required, but only if diagnostic tests have ruled out any contraindications, and after Eurotransplant has found a recipient. This implies that the patient needs to arrive earlier when his lungs are donated.

In the hospital, euthanasia will be performed in a patient room located near the operating room, which is spacious enough to allow relatives to be present, and where interference with other patient care is minimal.

The euthanasia drugs will be collected from the hospital's pharmacist by a physician. After all stakeholders have arrived, a nurse inserts an intravenous cannula, but is legally not allowed to administer the euthanasia drugs. A Dutch guideline on how to perform euthanasia requires the physician to administer a sedative (the barbiturate thiopental or 
the hypnotic agent propofol), followed by a muscle relaxant. ${ }^{16}$ While a barbiturate is potentially cardiotoxic, propofol is commonly used for general anesthesia, and thus does not cause harm to the donated organs.

The patient is not put on a monitor, since this could misguide the physician by a pulseless electric activity (PEA). The Health Council of the Netherlands stipulated in a recent proposition to the Minister of Health that "circulatory death is ascertained by recording the absence of an intra-arterial pressure wave or based on another current method of monitoring circulation. A no-touch period of five minutes is then observed. After this time has elapsed, irreversible circulatory and respiratory arrest exists and death may be declared". ${ }^{17}$ Even though this procedure is being followed in practice, this new protocol still has to be approved by the Minister of Health. The current guideline mentions the no touch period passes after determining death. ${ }^{18}$

If the euthanasia procedure would be performed at home, the 'performing' physician would not have a monitor available to determine death either, and death is thus based on absence of respiration and heart rate. The performing physician administers the euthanasia drugs in the presence of the patient's relatives and friends, if requested. After the performing physician has determined death, he informs the municipal coroner. The patient is transported to the operating room, where the surgical team is on standby. After organ procurement, the organs are transported to the various recipients.

\section{Aftercare}

The nurse and the second transplant coordinator assist the relatives during this process. A private family room is available, where the relatives can retreat and wait until the procedure has ended. The deceased will be laid out in the morgue of the hospital, but can also be transported to another morgue or home.

Within two weeks after the procedure, a debriefing is held to discuss any moral distress which may have arisen in any of the health staff involved, and to review all legal, ethical and practical aspects. The regional review committee is informed by the municipal coroner and verifies whether the performing physician has complied with the due diligence requirements performing euthanasia. Might this committee be convinced that not all requirements were fulfilled, it is obliged to inform the Dutch Health Care Inspectorate. This Dutch Health Inspectorate can inform the public prosecutor, after which a court could condemn the physician. In the donation after euthanasia procedures 
up to now, the Dutch Health Inspectorate has ascertained that all requirements were fulfilled. If this had not been the fact, this would not necessarily have implied that the organ donation procedure was unlawful as well.

\section{Conclusion}

The Dutch Euthanasia and Organ Donation Acts provide sufficient possibilities for patients to donate their organs after euthanasia. Given the right of self-determination, such combined procedure may be ethically justifiable, although it should be acknowledged that many ethical issues remain and give rise to an ongoing debate. A physician who is confronted with a patient who wishes to undergo euthanasia may consider raising the possibility of organ donation, if no contra-indications are identified. The Dutch multidisciplinary practical manual provides a framework of the medical and logistical aspects of donation after euthanasia within the medical, legal, and ethical boundaries of the Dutch law. It has been used eight times until now and increases awareness of this relatively less known possibility for organ donation. 
Organ donation after euthanasia: A Dutch practical manual

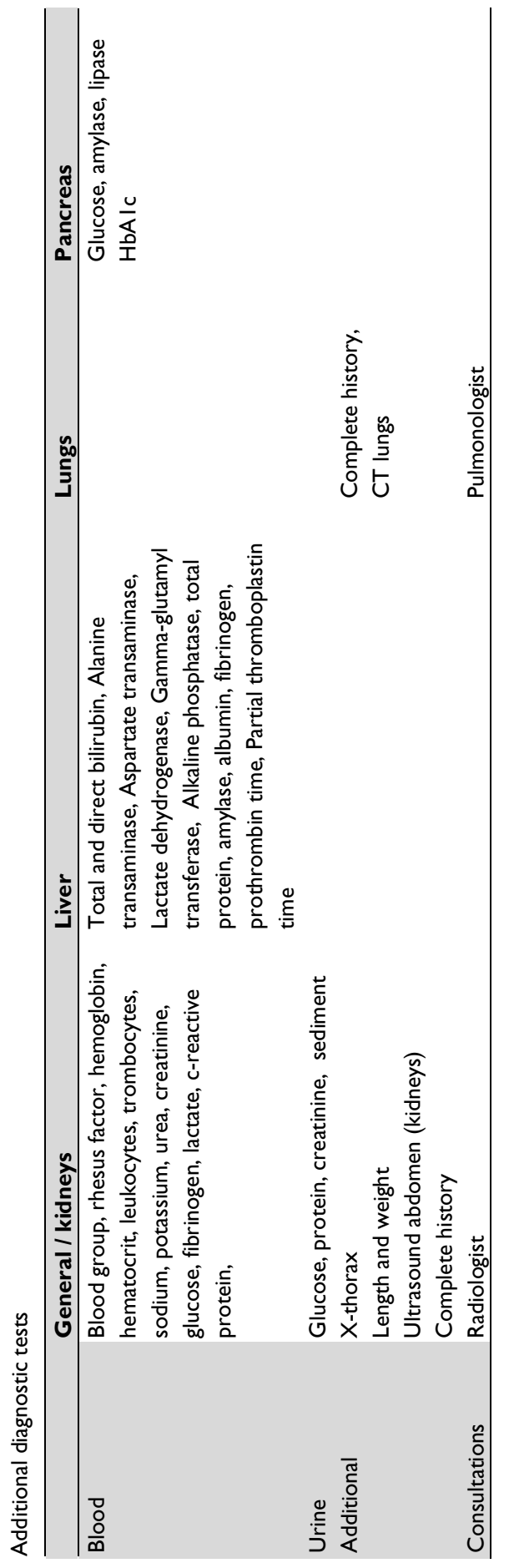




\section{References}

1. van Dijk G UF, Hamers R. Orgaandonatie na euthanasie bij een patiënt met een neurodegeneratieve aandoening. Ned Tijdschr Geneeskd. 2013;(157):A6548.

2. Ysebaert D, Van Beeumen G, De Greef K, Squifflet JP, Detry O, De Roover A, et al. Organ procurement after euthanasia: Belgian experience. Transplant Proc. 2009;41(2):585-6.

3. van Raemdonck D, Verleden GM, Dupont L, Ysebaert D, Monbaliu D, Neyrinck A, Coosemans $A$, Decaluwe H, De Leyn P, Nafteux P, Lerut T. Initial experience with transplantation of lungs recovered from donors after euthanasia. Appl Cardiopulm Pathophysiol. 2011;15:38-48.

4. Euthanasia Act (Netherlands), April 12, 2001, [Wet houdende toetsing van levensbeëindiging op verzoek en hulp bij zelfdoding].

5. Cohen J, Van Landeghem P, Carpentier N, Deliens L. Public acceptance of euthanasia in Europe: a survey study in 47 countries. Int J Public Health. 2014;59(1):143-56.

6. Burial and Cremation Act (Netherlands), Article 7 sub 2, March 7,1991 [Wet op de lijkbezorging].

7. Organ Donation Act (Wet van 24 mei 1996, houdende regelen omtrent het ter beschikking stellen van organen (Wet op de orgaandonatie)).

8. Dhital KK, Iyer A, Connellan M, Chew HC, Gao L, Doyle A, et al. Adult heart transplantation with distant procurement and ex-vivo preservation of donor hearts after circulatory death: a case series. Lancet. 2015;385(9987):2585-91.

9. Bernat JL. Life or death for the dead-donor rule? N Engl J Med. 2013;369(14):1289-91.

10. Eurotransplant. Annual Report 2008, REC01.08 p. 24.

11. Holmes BB, Diamond MI. Amyotrophic lateral sclerosis and organ donation: is there risk of disease transmission? Ann Neurol. 2012;72(6):832-6.

12. Eurotransplant is the organization that facilitates patient-oriented allocation and crossborder exchange of deceased donor organs, www.eurotransplant.org

13. The Royal Dutch Medical Association has published a guideline about euthanasia in people with a reduced level of consciousness, http://knmg.artsennet.nl/Nieuws/ Overzichtnieuws/Nieuwsbericht/79396/KNMGrichtlijn-euthanasie-bij-een-verlaagd-bewustzijn-biedtartsen-houvast.htm.

14. Medical Treatment Contracts Act Article 7:462 ('Wet op de geneeskundige behandelingsovereenkomst', part of the Civil Code).

15. Burial and Cremation Act (Netherlands), Article 76 jo. Organ Donation Act (Netherlands), Article 17.

16. The Royal Dutch Medical Association, Guideline on how to perform euthanasia and assisted suicide, August 2012 (KNMG, Richtlijn Uitvoering euthanasie en hulp bij zelfdoding).

17. Health Council of the Netherlands. Determining death in postmortal organ donation Protocols and criteria, including an updated Brain Death Protocol. The Hague: Health Council of the Netherlands, 2015; publication no. 2015/13. ISBN 978-94-6281-040-2.

18. Dhanani S, Hornby L, Ward R, Shemie S. Variability in the determination of death after cardiac arrest: a review of guidelines and statements. J Intensive Care Med. 2012;27(4): 238-52. 


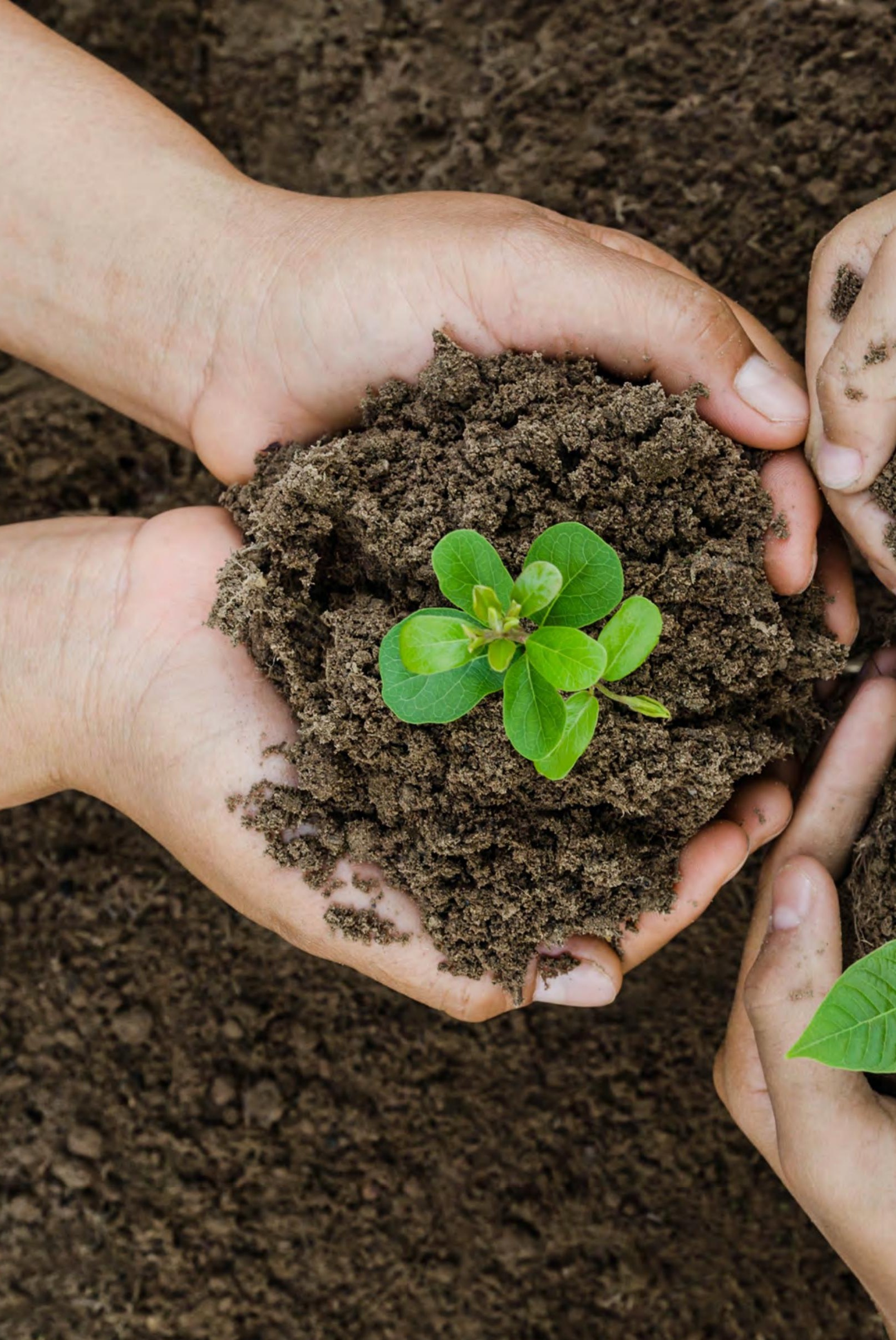





\section{Abstract}

Organ donation after euthanasia has been performed more than forty times in Belgium and the Netherlands together. Preliminary results of procedures that have been performed until now demonstrate that this leads to good medical results in the recipient of the organs. Several legal aspects could be changed to further facilitate the combination of organ donation and euthanasia. On the ethical side, several controversies remain, giving rise to an ongoing, but necessary and useful debate.

Further experiences will clarify whether both procedures should be strictly separated and whether the dead donor rule should be strictly applied. Opinions still differ on whether the patient's physician should address the possibility of organ donation after euthanasia, which laws should be adapted, and which preparatory acts should be performed. These and other procedural issues potentially conflict with the patient's request for organ donation or the circumstances in which euthanasia (without subsequent organ donation) traditionally occurs. 


\section{Introduction}

In Western Europe there is growing acceptance that a person who is unbearably suffering should be enabled to die in a dignified way. ${ }^{1}$ In contemporary medical practice, euthanasia is legally only allowed in Belgium, the Netherlands, Luxembourg and Colombia.

Organ transplantation is a lifesaving medical treatment for patients with organ failure, which provides survival benefit with improved quality of life. ${ }^{2}$ However, a persisting discrepancy between the number of organ donors and the number of patients on the waiting lists for transplantation is observed. In 2015, 1694 patients were registered on the waiting list for organ transplantation in the Netherlands, while 852 post mortem organs were donated. ${ }^{3}$ In Belgium, on January 1, 2016, 1.288 patients were on the waiting lists, while 1091 organs were donated in $2014 .{ }^{4}$ Fortunately, a rise in the number of registered organ donors is being observed over the years.

After the first case of organ donation after euthanasia in Belgium in 2005, allocation of donor organs after euthanasia within the Eurotransplant region was considered acceptable in 2008. ${ }^{5}$ A prerequisite put forward by the Belgian centres was that allocating these organs would only be an option in countries where euthanasia is legally possible, provided that this information is communicated to the transplant centre, and under the condition that both euthanasia and organ donation are separated as much as possible. Therefore, organs from donation after euthanasia are currently only transplanted in Belgium and the Netherlands. The fact that combinations of euthanasia and organ donation have already been performed does not necessarily create justification for it. In published Belgian articles about this procedure, patients were between 44 and 62 years old, and most patients were suffering from a stroke or multiple sclerosis. ${ }^{6}$

In the Netherlands, several patients who underwent euthanasia became organ donors, but so far only one patient, suffering from a neurodegenerative disease, has been described in scientific literature. ${ }^{7}$ Euthanasia was performed by his general practitioner in an intensive care department. As of December 2015, organ donation after euthanasia has reportedly been performed 15 times in the Netherlands (unpublished data). Next to that, transplant coordinators in Belgium and the Netherlands notice a contemporary trend towards an increasing willingness and motivation to undergo euthanasia and to subsequently donate organs as well (personal communication), supported by the increasing number of publications in popular media on this topic. 
It should be acknowledged that since malignancy is a contra-indication for organ donation, only a small - but still substantial - percentage of people who undergo euthanasia is eligible for organ donation. ${ }^{8}$ Of the 5306 times euthanasia has been performed in the Netherlands in 2014, in 1418 patients, suffering was not caused by malignancy. ${ }^{9}$ In Belgium, in 2013, 1807 patients underwent euthanasia, of which 565 patients did not suffer from malignancy. ${ }^{10}$ The number of potential donors becomes smaller when other contra-indications than malignancy are also taken into account.

This article explores the legal and ethical requirements and boundaries of organ donation after euthanasia in Belgium and the Netherlands. Since different ethical approaches to this topic exist, the authors have attempted to weigh relevant viewpoints, either sympathetic with, or opposing to the idea of organ donation after euthanasia in this article. The theoretical possibility of organ donation after assisted suicide will be touched upon briefly.

\section{Legal aspects of euthanasia and organ donation in Belgium and the Netherlands}

\section{Belgian law on euthanasia}

According to the Belgian Euthanasia Act, a physician can be held accountable, but is not criminally liable or responsible for performing euthanasia on a mentally competent person if this person requests this voluntarily, deliberately and repeatedly, and when the patient is in a medically hopeless condition and experiencing constant and unbearable physical or psychological suffering. ${ }^{11}$ The physician should inform the patient adequately about the available treatment options, and should make sure that another independent physician is consulted.

If the patient is ill, but when he is not expected to die within the near future (terminally ill), a third physician, with specific expertise regarding the condition from which the patient suffers, needs to consult the patient, and a period of at least one month between the request for euthanasia and the euthanasia procedure itself has to be respected. After euthanasia has taken place, the resulting death can be classified as a natural death, as formulated in Article 15 of the Euthanasia Act, thereby waiving the necessity to inform the public prosecutor or coroner. The performing physician fills out the patient's death certificate and sends a report to the federal monitoring and 
evaluation committee for euthanasia within four days. That authority will assess whether the procedure has been correctly performed.

\section{Dutch law on euthanasia}

In 2002 euthanasia was codified in the Netherlands. Physicians are excluded from criminal liability if they have met the requirements of the Law on Euthanasia, and have subsequently reported death by euthanasia to the municipal coroner. ${ }^{12,13}$

Article 2 of the Dutch Euthanasia Act requires that predefined due diligence requirements have to be fulfilled regarding euthanasia. The patient's request must be to undergo euthanasia. He should do this voluntarily and well considered, while being well informed. The patient should be hopelessly and unbearably suffering, and other reasonable solutions should be non-available. In this process, a second independent physician should be consulted. The euthanasia procedure should be carried out 'carefully', according to the latest standards.

In the Netherlands, euthanasia is considered a non-natural death. The Burial and Cremation Act provides that, when a patient dies from non-natural causes and wants to be a donor, consent from the public prosecutor for release of the body and organ donation has to be obtained. The municipal coroner and public prosecutor are informed in advance and should be available peri-procedurally to facilitate immediate release of the body. Another possibility is to obtain formal permission for the donation procedure from the public prosecutor beforehand. In that case the municipal coroner can chose to perform an autopsy after the organs have been removed.

The municipal coroner informs the regional euthanasia review committee, which then investigates whether the procedure was legitimate. He also fills out an 'Article 10'-form regarding death caused by a non-natural cause, which he hands over to the public prosecutor afterwards.

\section{Belgian law on organ donation}

In Belgium, there is a presumed consent (opt-out) system for organ donation. Anyone who is registered in the population register or who has been registered in the foreigners register for more than six months is eligible for organ donation after death in Belgium. The physician should verify that the donor has not expressed objection to organ donation, which requires consultation of the National Registry and discussing this with the relatives. In the National Registry, a declaration about one's donation preference can 
be registered, which can be a confirmation of a positive registration, or a negative registration in case of an objection.

When a patient is determined dead on the basis of either circulatory or neurological criteria, the treating physician is legally allowed to remove his organs for transplantation. In case of donation, three non-treating physicians, who are not involved in the transplantation procedure, should independently determine death. The law explicitly states that relatives should be enabled to say farewell to the deceased as soon as possible after the donation procedure. ${ }^{14}$

\section{Dutch law on organ donation}

In the Netherlands, there is an opt-in system, so that residents can actively decide whether they want to be an organ donor or not. At the age of 18 years, they receive a written request to register with the Donor registry.

Dutch inhabitants have the possibility to choose between 'Yes, I want to be a donor' or 'No', or to 'leave the decision to a family member' or to another specific individual. If a person is not registered, his relatives will have to decide whether they consent with or object to organ donation.

\section{Ethical considerations}

\section{General}

In the context of organ donation after euthanasia, the right of self-determination is a paramount ethical and legal aspect. It is the patient's wish and right to die in a dignified way, and likewise his wish to donate his organs is expressed. Organ donation after euthanasia enables those who do not wish to remain alive to prolong the lives of those who do, and also - compared to 'classical' donation after circulatory death - allows many more people to fulfill their wish to donate organs after death. ${ }^{15}$ This differs from the more common donation scenario, where relatives have to decide, often without knowing the patient's wish.

In a majority of cases, patients choose to die through euthanasia at home, where no other professionals than the performing physician are present or involved. ${ }^{10,16}$ After the physician has determined death, relatives have an extensive opportunity to say farewell to the deceased. When combining organ donation and euthanasia, the patient needs to 
be hospitalized when the physician administers the euthanasia drugs, facilitating optimal organ recovery and optimizing transplantation success of these organs. It can be envisaged that it would be more difficult for the patient and his relatives to spend their last hours together in this 'cold' environment. More importantly, after the physician has determined death, the patient has to be transported to the operating room immediately. The patient's relatives are informed that they should say goodbye to their beloved person before the euthanasia drugs are being administered, since time between death and organ donation should be minimized.

This could be considered an extra burden for patients who are already suffering unbearably and contributes to the emotional burden of the relatives as well. Practice from Belgium as well as the Netherlands has however demonstrated that patients who have deliberately chosen for this combination do not experience this as an obstacle, and relatives appear very supportive of the patient's last wish despite the potential extra burden. It should be underscored that it is beyond dispute that relatives need to be adequately pre-informed, and that there should be sufficient support for them as soon as the deceased is being transported to the operating room as well.

Even though both countries allow euthanasia in children (in the Netherlands only in minors over 12 years of age), it is assumed that organ donation after euthanasia will not be performed in this age category. Euthanasia in minors has only been performed a few times in the Netherlands and - as far as the knowledge of the authors reaches - not at all in Belgium. In the reported cases, the minors suffered from malignancy, which makes them unlikely to be eligible for organ donation.

\section{The physician's dilemma}

The treating physician of a patient meeting the due diligence requirements for euthanasia, without contraindications for organ donation, is confronted with a dilemma. Informing a patient about the possibility of organ donation after euthanasia could put a lot of social pressure on the patient, since he could feel pressed to consent. It could potentially even cause a breach of trust with the treating physician, and one might get the impression that the physician is only willing to perform euthanasia because the patients will donate organs. Not mentioning the option of organ donation may give rise to frustration among relatives when the existence of such possibility is brought to their attention after euthanasia. This could also be, given the Hippocratic Oath, considered as a conflict with the (weak) moral obligation of a physician to help those in need of an organ. 
A Dutch physician who is confronted with this dilemma should, according to the authors, consult the Donor Registry. In case of a positive registration as a potential organ donor, there is no formal objection to discuss the matter with the patient, using this registration as a basis for discussion. Even when confronted with a refusal for organ donation or no registration at all the physician could still decide to discuss this topic with the patient, since the changed circumstances in the current phase of life might have changed the patient's opinion. The patient could be very relieved discovering the existence of this option and receiving the possibility to give meaning to his or her own suffering, by the option of potentially relieving the suffering of others.

Not all clinicians are convinced that it would be (ethically) appropriate to inform a patient about the existence of such combined procedure. It is perhaps feared that striving for organ donation may compromise the correct application of the euthanasia procedure. This is why organizations focusing on dignified end-of-life have developed a brochure to indirectly inform people on the possibility of organ donation after euthanasia.

\section{Preparatory acts regarding organ donation}

From a transplantation perspective, diagnostic tests are necessary and unavoidable to ascertain and preserve the quality of the organs. The Dutch Law on Organ Donation provides the possibility to examine a potential donor and the quality of his organs, when it is certain that the patient will die within a so-called "limited period of time". ${ }^{17}$ As long as these examinations do not interfere with the medical treatment of the patient, physicians can prepare and perform measures that are deemed necessary to prepare for transplantation.

The Belgian Law on Organ Donation neither mentions preparatory measures, nor does the Law on Patients' Rights prohibits it. This provides a physician not only with the possibility to investigate the donor's organs, but also with more opportunities to make organs suitable for transplantation. As opposed to the Netherlands, Belgian physicians can administer heparin to the patient. ${ }^{18.19}$ It is their opinion that, as it is certain the patient will die because of the euthanasia drugs, administering heparin does not 'harm' the patient. Current Dutch opinion is that it is unethical to 'treat' the patient to keep his organs in good condition. It is argued that a physician can only act in favor of the patient (and not in favor of the recipient), a point of view that can also be found in the Dutch legislation concerning medical treatment. ${ }^{20}$ 
Under these circumstances, it can be seen as an advantage that - in contrast to a normal donation procedure where a patient is often unconscious - the physician is able to discuss preparatory acts with the patient. It is still a matter of debate to which extent the patient may agree with 'extensive donor management' like preparatory investigations and administration of heparin, anticipating donation after euthanasia. Other advantages of organ donation after euthanasia are the possibility for the patient to discuss this topic with his relatives, and that the patient's organs can be matched beforehand, even though it is still a question whether the patient should be informed about these results and when the recipient should be informed about a possible donor organ.

\section{Discussion}

\section{Organ donation after assisted suicide}

Shaw previously reported on the possibility of organ donation after assisted suicide in Switzerland. ${ }^{21}$ He reasoned that $50 \%$ of all people who undergo euthanasia could donate their organs by undergoing euthanasia in a non-medical environment, followed by immediate transport by ambulance to the hospital's operating room. Although theoretically feasible, this seems unlikely to result in organs viable for transplantation. It is unclear how long the death process will take and what kind of impact it will have on the patient's organs and tissues. Low blood pressure and/or saturation could harm the organs, making them unfit for donation.

The Dutch Model Protocol on post moral organ and tissue donation mentions a time frame of maximum 30 minutes between circulatory death and preservation of the abdominal organs. It is unlikely that the process will be completed within this time frame.

The estimation Shaw makes about the possible impact on the waiting lists can be nuanced, since many people who commit assisted suicide suffer from malignancy, which makes it impossible to donate organs. ${ }^{10,16}$ Next to that, age limits for donating certain organs apply.

\section{Improving the legal framework}

In the Netherlands, future acceptance of euthanasia as a natural death could perhaps further facilitate the combination with organ donation, even though the procedure should then still be investigated by the regional review committees. It should however 
be acknowledged that this cooperation in current practice is most commonly optimal, rarely hampering the process, and that such a legislative change is not expected in the near future.

In Belgium, the current policy of determination of death by three independent physicians could be abandoned, facilitating a more lean procedure with only one physician. By giving a physician the advice to propose organ donation after euthanasia in a patient who is about to undergo euthanasia, the patient's autonomy could be further improved.

On the other hand, these measures have been put in place to protect patients and to avoid the public opinion thinking that physicians will exert less effort caring patients who could be an organ donor.

\section{Separation of the procedures}

Legally, it is stated that both procedures should be strictly separated. However, when a patient becomes ill he might already mention that he prefers to undergo euthanasia when suffering becomes unbearable. From that moment on, multiple conversations between the physician and his patient will take place, discussing different options for pain relief and sedation. During this time frame, the subject of organ donation could come under the attention.

A patient might be motivated to request euthanasia because this gives him the opportunity to donate organs. As long as all due diligence requirements are fulfilled, it should not be an obstacle if euthanasia and donation are not fully separated. One however needs to avoid the public having the perception that anyone who is ill and willing to donate his organs, will be able to undergo euthanasia, or that a physician would motivate a patient to undergo euthanasia because of organ donation possibility. The public needs to have confidence in the ability of a physician to judge objectively, and acknowledge that strict legal criteria and boundaries regarding euthanasia and organ donation exist.

\section{The dead donor rule}

The dead donor rule states that donation should not cause or hasten death. ${ }^{22}$ Since a patient undergoing euthanasia has chosen to die, it is worth arguing that the no-touch time (depending on the protocol) could be skipped, limiting the warm ischemia time, and contributing to the quality of the transplanted organs. ${ }^{23}$ It is even possible to extend this 
argument to a 'heart-beating organ donation euthanasia' where a patient is sedated, after which his organs are being removed, causing death. ${ }^{24}$ Both options are currently legally not allowed.

\section{Conclusion}

Physicians should be aware that those who request euthanasia could be potential organ donors. Discussing this subject between physician and patient is an ultimate form of answering the right to self-determination, and from a legal and ethical perspective the issue can both be raised by the patient or the treating physician.

Combining euthanasia and organ donation in a so called 'donation after circulatory death' - procedure seems feasible on legal, ethical or medical grounds, and is increasingly gaining social acceptance in both Belgium and the Netherlands. Since current legislation does not specifically focus on the - when drafted unpractised - combination, future redrafting may be necessary in perspective of the contemporary developments regarding occurrence of such combined procedures. 


\section{References}

1. Cohen J, Van Landeghem P, Carpentier N, Deliens L. Public acceptance of euthanasia in Europe: a survey study in 47 countries. Int J Public Health 2014;59(1):143-56.

2. Kugler C, Gottlieb J, Warnecke G, et al. Health-related quality of life after solid organ transplantation: a prospective, multiorgan cohort study. Transplantation 2013;96(3):316-23.

3. Dutch Transplant Society, Annual Report 2013:9-11.

4. Eurotransplant, Belgium, http://www.eurotransplant.org/cms/index.php?page=pat_belgium.

5. Eurotransplant, Annual Report 2008, REC01.08:24.

6. Ysebaert D, Van Beeumen G, De Greef K, et al. Organ procurement after euthanasia: Belgian experience. Transplant Proc 2009;41(2):585-6.

7. van Dijk G UF, Hamers R. Orgaandonatie na euthanasie bij een patiënt met een neurodegeneratieve aandoening. Ned Tijdschr Geneeskd 2013;(157):A6548

8. Bollen J, de Jongh W, Hagenaars $\mathrm{H}$, et al. Organ donation after euthanasia A Dutch practical manual. Am J Transplant 2016;16(7):1967-72.

9. Regionale toetsingscommissies euthanasie, Jaarverslag 2014, The Hague, August 2015.

10. Federal monitoring and evaluation committee on euthanasia, Sixth report to the legislative chambers (2012-2013), June 24, 2014.

11. Euthanasia Act (Belgium), May 28, 2002 [Wet betreffende de euthanasie].

12. Organ Donation Act (Netherlands), May 26, 1996 [Wet houdende regelen omtrent het ter beschikking stellen van organen (Wet op de orgaandonatie)].

13. Burial and Cremation Act (Netherlands), March 7, 1991 [Wet op de lijkbezorging].

14. Organ Donation Act (Belgium), June 13, 1986 [Wet betreffende het wegnemen en transplanteren van organen].

15. Shaw D. Saving Lives with Assisted Suicide and Euthanasia: Organ Donation After Assisted Dying. In: Cholbi M, Varelius J, eds. New Directions in the Ethics of Assisted Suicide and Euthanasia: Springer International Publishing, 2015:185-92.

16. Dutch Regional review committees, Annual Report 2013, August 2014, p.6.

17. Organ Donation Act (Netherlands) [Wet op de orgaandonatie], Article 20.

18. Motta ED. The ethics of heparin administration to the potential non-heart-beating organ donor. J Prof Nurs 2005;21(2):97-102

19. D. Van Raemdonck GMV, L. Dupont, D. Ysebaert, D. Monbaliu, A. Neyrinck, W. Coosemans, H. Decaluwe, P. De Leyn, P. Nafteux, T. Lerut. Initial experience with transplantation of lungs recovered from donors after euthanasia. Applied Cardiopulmonary Pathophysiology 2011;15:38-48.

20. Medical Treatment Contracts Act, Article 7:466 sub 2 [Wet op de geneeskundige behandelingsovereenkomst (part of the Civil Code)].

21. Shaw DM. Organ donation after assisted suicide: a potential solution to the organ scarcity problem. Transplantation 2014;98(3):247-51.

22. Bernat JL. Life or death for the dead-donor rule? N Engl J Med 2013;369(14):1289-91.

23. Wind J, Faut M, van Smaalen TC, van Heurn EL. Variability in protocols on donation after circulatory death in Europe. Crit Care 2013;17(5):R217. 
24. Wilkinson D, Savulescu J. Should we allow organ donation euthanasia? Alternatives for maximizing the number and quality of organs for transplantation. Bioethics 2012;26(1): 32-48. 


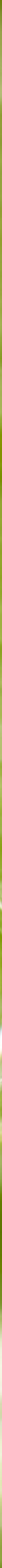




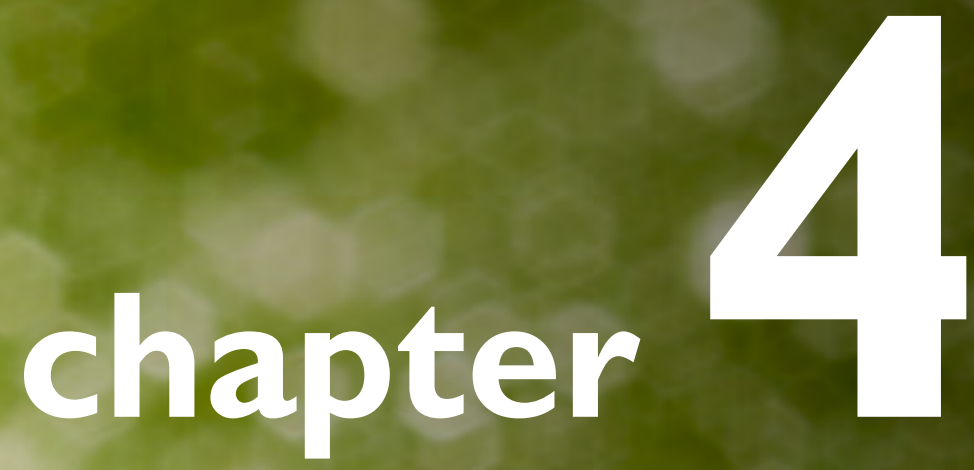

\section{Orgaandonatie na euthanasie:} juridische overwegingen en vraagstúkken

Mr. drs. J.A.M. Bollen, prof. dr. L.W.E. van Heurn, prof. dr. D. Ysebaert, prof. dr. W.N.K.A. van Mook en mr. dr. M.M. ten Hoopen Tijdschrift voor Gezondheidsrecht 2019:107-2I 
This chapter was written in Dutch and published in the Dutch Journal of Health Law (Tijdschrift voor Gezondheidsrecht). It provides a detailed overview of all legal aspects concerning organ donation after euthanasia in the Netherlands. Because of the very specific in-depth investigation, and because an English version would be very confusing for those who do not have any background knowledge of Dutch law, it was decided not to translate it. A summary of the liability issues that are researched here can be found in the 'liability' section in the general discussion (Chapter 9). 


\section{Inleiding}

Terwijl euthanasie ethisch en juridisch gezien nog steeds tot discussies leidt, gaan de ontwikkelingen door. Er dienen zich situaties aan die nog een dimensie aan het euthanasievraagstuk toevoegen. Dit werd een aantal jaren geleden duidelijk toen de eerste gevallen in het nieuws kwamen van patiënten die de wens hadden om, na een door hen te ondergane euthanasie, één of meer organen te doneren. Zorgaanbieders en -verleners kwamen voor de vraag te staan of dit wel mogelijk is.

Aanvankelijk was de reactie in de praktijk terughoudend. Onbekendheid met de procedure bracht onzekerheid mee over de implicaties ervan, zowel medisch-technisch als in ethische en juridische zin. ${ }^{1}$ Vergeleken met de lange tijd die nodig was voor de aanvaarding van de mogelijkheid van euthanasie, heeft het echter relatief kort geduurd voordat de combinatie euthanasie-orgaandonatie haar weg vond naar de medische praktijk. Het bleek niet nodig om de wetgeving aan te passen. Ook zal een rol hebben gespeeld dat euthanasie en orgaandonatie in Nederland geen nieuwe rechtsfiguren meer zijn; alleen de samenloop van beide brengt een verandering met zich mee.

In 2012 werd de combineerde euthanasie-orgaandonatie procedure in ons land voor het eerst uitgevoerd. In 2005 was zij al in België toegepast. Sindsdien neemt het aantal procedures per jaar toe. Eind 2018 hadden in Nederland al 50 patiënten organen gedoneerd na euthanasie. Hoewel het over de jaren heen gezien in beide landen dus om meerdere gevallen gaat, zal het totale aantal situaties waarin euthanasie en orgaandonatie in combinatie plaatsvinden in absolute zin wellicht beperkt blijven. Een patiënt die euthanasie zal ondergaan dient in de eerste plaats medisch geschikt te zijn voor het doneren van organen. Indien men lijdt aan een maligniteit wordt orgaandonatie onmogelijk, en ook de leeftijd speelt een rol. Met name patiënten die lijden aan een neurodegeneratieve ziekte, zoals multiple sclerose (MS), amyotrofische laterale sclerose (ALS) of de ziekte van Huntington zijn in beginsel geschikt om als donor te fungeren. De tot nu toe beschikbare cijfers over de resultaten van transplantaties die plaatsvonden na een gecombineerde euthanasie-donatieprocedure zijn gunstig, maar nog vrij beperkt voorhanden. $^{2}$

Uit eerder onderzoek van geanonimiseerde Belgische euthanasiedata blijkt dat 10,2\% van alle patiënten die op medische gronden euthanasie ondergaan in aanmerking zou kunnen komen voor orgaandonatie. ${ }^{3}$ Niet iedere patiënt binnen deze groep zal ook orgaandonor willen zijn, ook omdat hij dan voorbereidende onderzoeken dient te ondergaan en zal moeten overlijden in het ziekenhuis. Dit neemt niet weg dat een 
euthanasieprocedure die gevolgd wordt door orgaandonatie een bijdrage kan leveren aan het beschikbaar komen van organen voor patiënten die op een donororgaan zijn aangewezen. Orgaandonatie na euthanasie kan de periode bekorten waarin transplantatiepatiënten op een wachtlijst staan.

Een tweede positief effect van de combinatie euthanasie-orgaandonatie is dat zij de wens in vervulling kan doen gaan van patiënten die aan het einde van hun leven graag nog iets voor een ander betekenen.

In dit laatste schuilt juridisch en ethisch gezien echter juist ook een gevaar. De wilsverklaring gericht op euthanasie mag niet beïnvloed worden door de wil om nog iets goeds te doen voor een ander. Zij moet in vrijheid tot stand komen. Dit geldt ook omgekeerd, voor de arts die te maken heeft met een patiënt die een euthanasiewens heeft en tegelijkertijd een (potentiële) kandidaat voor donatie is. Hoe kan vermenging van belangen worden voorkomen? Daarnaast doen verdere ontwikkelingen, zoals organ donation euthanasia (ODE), vragen rijzen. Deze vragen zien met name op de afbakening van de gevallen waarin euthanasie te combineren is met donatie. Van ODE is sprake indien de patiënt niet overlijdt door de euthanasiemedicatie, maar door het uitnemen van organen, inclusief het hart, nadat hij zijn bewustzijn heeft verloren door de toepassing van anesthesie (zie nader par. 4.8). ${ }^{4}$

In dit artikel staan de hiervoor genoemde aspecten en vragen betreffende orgaandonatie na euthanasie centraal. Het is niet de bedoeling om de relevante gezichtspunten uitputtend in kaart te brengen, maar wel om een goed beeld te geven van het onderwerp vanuit zowel een medische als een juridische invalshoek.

Eerst volgt een schets van het feitelijke verloop van de procedure waarbij zowel euthanasie als orgaandonatie plaatsvindt. Dit laat alvast zien waar medisch en juridisch gezien beslismomenten en mogelijke knelpunten liggen. Hierna komt aan de orde aan welke eisen de procedure van euthanasie en orgaandonatie dient te voldoen. Naast de wetgeving inzake euthanasie en orgaandonatie (de WOD in zijn huidige en zijn toekomstige vorm) staat de relevante zelfregulering (richtlijn inzake orgaandonatie na euthanasie) hier centraal. ${ }^{5}$

Vervolgens richt de aandacht zich op de kern van het onderwerp: de juridisch-ethische dilemma's aangaande de gecombineerde procedure euthanasie-orgaandonatie. Deze dilemma's vormen ook het hoofdbestanddeel van de conclusie waarmee dit artikel wordt afgerond. Hoewel de ontwikkelingen in België omtrent orgaandonatie na 
euthanasie eveneens een beschouwing waard zijn, vormt de Nederlandse situatie bij de bespreking het uitgangspunt.

Van belang om op te merken is dat de auteurs zich uitdrukkelijk niet willen uitspreken voor of tegen de combinatie van euthanasie en orgaandonatie. De intentie is vooral om de lezer te informeren over de procedure waarbij euthanasie wordt gevolgd doororgaandonatie. Wel wordt hier en daar een mogelijke (denk)richting aangegeven.

\section{Euthanasie en orgaandonatie: schets van de procedure}

De in 2017 tot stand gekomen Richtlijn orgaandonatie na euthanasie bestaat uit een deel met instructies voor de praktijk en een deel met achtergronden, waarin onder andere de ethische aspecten en wettelijke kaders van de gecombineerde procedure worden besproken. ${ }^{5}$ In deze paragraaf worden stapsgewijs de verschillende onderdelen belicht die noodzakelijk zijn om de procedure correct te kunnen uitvoeren. ${ }^{6}$

Door de behandelend arts dient vastgesteld te zijn, na het oordeel van de tweede onafhankelijke arts (meestal een SCEN-arts (Steun en Consultatie bij Euthanasie in Nederland)), dat aan alle zorgvuldigheidseisen voor euthanasie is voldaan. De behandelend arts is in dit geval doorgaans de huisarts met wie de patiënt een behandelingsovereenkomst heeft op basis van art. 7:446 BW, of de verpleeghuisarts met wiens werkgever (het verpleeghuis) een behandelingsovereenkomst is gesloten. Indien er geen duidelijke contra-indicaties voor orgaandonatie bestaan, zoals een maligniteit, kan het verzoek tot orgaandonatie besproken worden. Dit dient op initiatief van de patiënt te gebeuren. Men tracht op deze manier de invloed te beperken die de wens tot orgaandonatie kan hebben op de euthanasiewens. Later in dit artikel wordt in gegaan op de vraag wat dit betekent voor de autonomie van de patiënt (par. 4.5).

Indien de wens van de patiënt tot orgaandonatie blijft bestaan na informatieverstrekking door de behandelend arts, neemt deze arts contact op met de transplantatiecoördinator en de donatie-intensivist van een universitair medisch centrum (UMC). Er dient dan onderzocht te worden of de patiënt op medische gronden een potentiële donor is en welke organen in aanmerking komen voor donatie. Er is toestemming van de patiënt nodig om de relevante medische gegevens te controleren, maar ook om enkele voorbereidende onderzoeken uit te voeren. Het gaat dan om onderzoek van urine en bloed, maar ook om beeldvormend onderzoek. 
Het beeldvormend onderzoek wordt meestal uitgevoerd in het ziekenhuis op de dag van de procedure. Indien de uitslag daarvan geen bijzonderheden oplevert, gaat Eurotransplant op zoek naar potentiële ontvangers. Eurotransplant beheert de transplantatiewachtlijsten van acht Europese landen. De personen die in aanmerking komen voor transplantatie van een orgaan worden geïnformeerd en dienen zich alvast naar het ziekenhuis te begeven. Hoewel de patiënt die wil doneren te allen tijde vrij is om de procedure te staken, kan hij dus wel druk ondervinden indien hij erover wordt ingelicht dat er ontvangers voor zijn organen zijn gevonden en zijn benaderd. Er kan eventueel ook druk ontstaan om de procedure te annuleren en de euthanasie alsnog thuis door te laten gaan indien blijkt dat er geen geschikte ontvangers gevonden werden.

In aanwezigheid van de naasten van de patiënt dient de arts het euthanaticum toe, conform de Richtlijn uitvoering euthanasie en hulp bij zelfdoding van Koninklijke Nederlandse Maatschappij ter bevordering der Pharmacie (KNMP). Dit gebeurt in een patiëntenkamer dichtbij de operatiekamers, wat meestal impliceert: in een kamer op de intensive care afdeling. Wanneer de circulatiestilstand intreedt, wordt er vijf minuten gewacht, de zogenaamde no touch tijd, die ingevolge art. 14 lid 1 WOD en het Modelprotocol Postmortale orgaan- en weefseldonatie in acht dient te worden genomen. ${ }^{7}$ Gedurende deze periode mogen er geen invasieve handelingen worden verricht bij de patiënt, opdat eventuele autoresuscitatie (waarbij de circulatie van de patiënt 'spontaan' herstart, ook aangeduid als het zogenaamde Lazarus syndroom) uitgesloten kan worden. Vervolgens kan het overlijden worden vastgesteld.

Daarna wordt de overledene zo snel mogelijk verplaatst naar de operatiekamer om de uitnameprocedure te starten. De circulatiestilstand vormt namelijk het begin van de zogenaamde warme-ischemietijd (de organen lijden aan zuurstoftekort), die men zo kort mogelijk wenst te houden. Omdat euthanasie een niet-natuurlijk overlijden is, behoort de Officier van Justitie (OvJ) toestemming te geven voor zowel de verplaatsing van de overledene als de orgaandonatie (art. 76 lid 1 jo. 2 Wet op de lijkbezorging). Daarom dient het te verwachten overlijden op voorhand gecommuniceerd te worden met de OvJ, opdat deze snel beschikbaar zal kunnen zijn. Ook de gemeentelijke lijkschouwer dient van tevoren geïnformeerd te worden, om op het betreffende moment aanwezig te kunnen zijn en snel een schouwing te kunnen uitvoeren.

Vervolgens worden de organen op aangeven van Eurotransplant vervoerd naar de ontvangers. Het is niet mogelijk voor de donor om op voorhand een ontvanger van een specifiek orgaan aan te duiden (zie nader par. 4.6). 


\section{De voor de combinatie euthanasie-orgaandonatie relevante wet- en regelgeving}

\subsection{Euthanasie}

De patiënt die euthanasie wenst te ondergaan dient te voldoen aan de zorgvuldigheidseisen van art. 2 Wet toetsing levensbeëindiging op verzoek en hulp bij zelfdoding (WTL). Daartoe behoort, naast de eis van uitzichtloos en ondraaglijk lijden, onder andere de eis van een vrijwillig en weloverwogen verzoek. De grootste uitdaging bij de gecombineerde euthanasie-orgaandonatieprocedure is de beoordeling van dit aspect. Er bestaat namelijk een kans dat de patiënt tot de wens komt om euthanasie te ondergaan wegens het feit dat hij dan in de mogelijkheid verkeert om zijn organen te doneren. Hoewel de patiënten die tot op heden de gecombineerde procedure hebben ondergaan zeer tevreden waren over het feit dat ze een positieve betekenis konden geven aan hun lijden, mag dit niet het (enige) motief zijn. Het euthanasieverzoek behoort voort te komen uit het uitzichtloos en ondraaglijk lijden. Dit is meteen ook de reden waarom de Richtlijn orgaandonatie na euthanasie en de literatuur een strikte scheiding verlangen van de beide procedures. ${ }^{8}$ Het is aan de behandelend arts en de onafhankelijke arts (SCEN-arts) om een euthanasieverzoek waarbij de patiënt reeds over orgaandonatie spreekt kritisch te beoordelen.

In 2017 ondergingen 6585 patiënten euthanasie, een aantal dat sinds de invoering van de WTL jaarlijks toeneemt. De regionale toetsingscommissies euthanasie (RTE), die ex post beoordelen of een euthanasieprocedure zorgvuldig werd uitgevoerd, hebben tot op heden in hun uitspraken geen bezwaar geuit tegen procedures waarin de euthanasie werd gevolgd door orgaandonatie. Zelfs in een casus waarin de patiënt thuis gesedeerd en geïntubeerd werd voorafgaand aan vervoer naar het ziekenhuis waar vervolgens de euthanasie plaatsvond, volgde geen negatief oordeel. ${ }^{9}$

De RTE publiceerden in 2018 een nieuwe euthanasiecode, de EuthanasieCode 2018, een leidraad voor euthanasieprocedures die de Code of Practice uit 2015 vervangt. ${ }^{10}$ Hierin wordt uitdrukkelijk gesteld dat de WTL geen uitspraken doet over wat er na euthanasie mag gebeuren met het lichaam. Wel wordt benadrukt dat de voorgenomen donatieprocedure de zorgvuldigheid van de euthanasieprocedure niet mag beïnvloeden.

\subsection{Orgaandonatie}

De Wet op de Orgaandonatie (WOD) maakt een onderscheid tussen het ter beschikking stellen van organen bij leven en het ter beschikking stellen van organen na overlijden. 
Binnen deze laatste categorie wordt er medisch gezien gesproken van donation after brain death (DBD) in het geval van hersendood, en van donation after circulatory death (DCD) nadat hartstilstand is ingetreden. Er bestaan volgens de medische literatuur vier categorieën DCD, die ook wel de 'Maastricht classificaties' genoemd worden. Orgaandonatie na euthanasie wordt in deze context beschreven als een 'type 3', vergelijkbaar met de situatie waarin de behandeling van een patiënt die is opgenomen op de intensive care afdeling wordt gestaakt. $\mathrm{Na}$ het stopzetten van de levensondersteunende maatregelen kan orgaandonatie plaatsvinden indien de patiënt binnen twee uur overlijdt.

Ook uit de WOD zijn geen argumenten af te leiden die een barrière opwerpen tegen de combinatie met euthanasie. In deze gecombineerde procedure bestaat er zelfs een voordeel in vergelijking met DBD en DCD. In deze laatste gevallen is het namelijk de familie die, indien een registratie van de patiënt als donor ontbreekt, op een emotioneel moment gevraagd wordt of orgaandonatie kan plaatsvinden, aangezien de patiënt zelf op dat moment bewusteloos is. Indien de patiënt zich wél als orgaandonor heeft geregistreerd in het Donorregister, zal de familie daarover geïnformeerd worden en zal men de uitnameprocedure kunnen starten. In de praktijk wordt hiervan afgeweken indien de donatie op ernstige psychische of emotionele bezwaren van de familie stuit. Nu de patiënt bij orgaandonatie na euthanasie echter zelf, bij vol bewustzijn en met volle overtuiging, te kennen heeft gegeven dat hij orgaandonor wil zijn, zal de familie zijn wens in de regel respecteren.

Vanaf 1 juli 2020 zal de nieuwe wetgeving gaan gelden waarmee de huidige WOD wordt gewijzigd. ${ }^{11}$ In het dan in te voeren actieve donorregistratiesysteem (ADR) is iedereen een potentiële orgaandonor, tenzij men een weigering heeft laten registreren. Wie, ondanks een verzoek daartoe per brief en een herinneringsbrief, geen keuze heeft gemaakt (bestaande uit: 1. Ja, ik geef toestemming; 2. Nee, ik geef geen toestemming; 3. Mijn partner of familie beslist; 4. De door mij gekozen persoon beslist), zal worden geregistreerd met de aanduiding 'Geen bezwaar'. Toestemming voor donatie wordt dan verondersteld, zolang er geen gebruik is gemaakt van de mogelijkheid om alsnog een keuze te maken en de registratie te wijzigen. Uiteindelijk hebben echter ook in dit systeem familieleden een bepaalde, laatste stem. ${ }^{12,13}$

De minister van Volksgezondheid, Welzijn en Sport (VWS) heeft in een brief van september 2017 aan de Eerste Kamer gesteld dat de nieuwe registratiesystematiek geen gevolgen heeft voor de procedure van orgaandonatie na euthanasie, aangezien het gaat om een bewuste en nadrukkelijke keuze van de patiënt. ${ }^{14}$ Ook eerder al, toen de richtlijn 
inzake orgaandonatie na euthanasie nog in ontwikkeling was, had de minister zich positief uitgelaten over de gecombineerde procedure naar aanleiding van Kamervragen van de Kamerleden Tellegen en Arib. ${ }^{15}$

\subsection{Euthanasie in combinatie met orgaandonatie}

Evenals bij DBD en DCD kunnen er bij orgaandonatie na euthanasie voorbereidende handelingen uitgevoerd worden. Denk aan onderzoek dat noodzakelijk is voor de voorbereiding van de transplantatie, zoals onderzoek van bloed en urine, maar ook beeldvormend onderzoek (art. 20 jo. 22 WOD). Het is vervolgens mogelijk om longen, nieren, lever en pancreas te doneren.

Op 12 december 2018 publiceerde de Gezondheidsraad een advies over het vaststellen van de dood bij orgaandonatie na euthanasie, naar aanleiding van een adviesaanvraag van de minister van VWS. De conclusie van een door de Gezondheidsraad ingestelde commissie is dat er geen reden is om voor deze specifieke procedure af te wijken van het 'normale' vaststellen van de dood bij postmortale orgaandonatie, zoals hiervoor beschreven. Opvallend is echter dat men adviseert om desgewenst een arteriële lijn te plaatsen bij de patiënt. Er wordt dan een soort infuus geplaatst in de slagader in de pols die op de monitor een curve weergeeft wanneer het hart bloeddruk creëert.

De auteurs zijn het om verschillende redenen, en vanuit praktische ervaringen, oneens met dit advies. Het plaatsen van een arterielijn kan - ook wanneer de eerste poging daartoe slaagt - door de patiënt namelijk als pijnlijk worden ervaren en daardoor voor deze een (extra) belasting opleveren. De lijn kan bovendien niet meer losgekoppeld worden, waardoor de patiënt minder mobiel is dan later wellicht wenselijk is. Ook is de uitvoerend arts meestal een huisarts, en daarmee iemand die in het algemeen geen ervaring heeft met het plaatsen of analyseren van een arterielijn. Het zal hierdoor nodig zijn om gebruik te maken van de hulp van een intensivist of anesthesioloog, en de patiënt zal moeten overlijden op bijvoorbeeld een intensive care afdeling waar de technische mogelijkheden voor de noodzakelijke monitoring beschikbaar zijn. De commissie noemt als argument voor het aanbrengen van de lijn dat hierdoor de warmeischemietijd zoveel mogelijk beperkt kan worden. Dit lijkt echter ook mogelijk te zijn wanneer de circulatiestilstand en het overlijden op de conventionele manier (door de pols te voelen of naar de hartslag te luisteren) vastgesteld worden. ${ }^{16}$ Gelet op het principe van de autonomie van de patiënt zou de te volgen werkwijze in ieder geval aan de patiënt uitgelegd kunnen worden, zodat hij hierover zelf zou kunnen beslissen. 


\section{Juridische en ethische vraagstukken}

\subsection{Nadere beschouwingen}

Vanuit juridisch perspectief lijkt er geen bezwaar te zijn tegen de combinatie van euthanasie en orgaandonatie. De relevante wetgeving bevat, zoals ook hiervoor opgemerkt, geen elementen die deze procedure verbieden. Hierbij verdient wel aantekening dat de wetgever, de laatste wijziging van de WOD daargelaten, waarschijnlijk geen rekening heeft gehouden met een samengaan van euthanasie met orgaandonatie. Aannemelijk is dat hij deze combinatie niet heeft voorzien. Dit neemt niet weg dat er juridisch gezien aspecten zijn die aandacht vragen en dat ook ethisch nog de nodige vragen rijzen.

\subsection{Toepasselijkheid van de Wkkgz en verantwoordelijkheid van het ziekenhuis}

De patiënt wordt op de dag van de euthanasie- en donatieprocedure opgenomen in een ziekenhuiskamer nabij de operatiekamers. Meestal voert de (verpleeg)huisarts de euthanasie uit, hoewel deze geen vaste relatie heeft met het ziekenhuis. De patiënt zal in de regel immers niet willen dat een in het ziekenhuis werkzame medisch specialist de euthanasie verricht nu een vertrouwensband met deze ontbreekt, tenzij zich de situatie zich voordoet dat de medisch specialist zélf langere tijd bij zijn behandeling betrokken is geweest. Een specialist die verbonden is aan het ziekenhuis zal in het algemeen ook niet díe - meer intensieve - behandelrelatie met de patiënt hebben die in een euthanasiecasus vereist is.

Nu de (verpleeg)huisarts bepaalde verrichtingen in het ziekenhuis uitvoert zonder dat hij daar op basis van een arbeidsovereenkomst werkzaam is, zal het ziekenhuis (Raad van Bestuur) op grond van art. 4 lid 1 onder b Wet kwaliteit, klachten en geschillen zorg (Wkkgz) met hem een schriftelijke overeenkomst van opdracht (toelating) moeten sluiten. Wij nemen hierbij aan dat dit vereiste, gezien de (ruime) strekking van de Wkkgz om de kwaliteit van de zorg te waarborgen, ook geldt in de onderhavige situatie, ook al is daarin sprake van een eigen, zelfstandige rol van de huisarts bij de euthanasie. Niet overtuigend lijkt ons de opvatting dat niet gesproken zou kunnen worden van 'zorg doen verlenen' door het ziekenhuis (als zorgaanbieder) in de zin van art. 4 lid 1 onder b Wkkgz. ${ }^{17}$

In de bedoelde overeenkomst zal onder meer de verplichting moeten zijn opgenomen dat de (verpleeg)huisarts zich bij zijn werkzaamheden laat leiden door de op het 
ziekenhuis rustende wettelijke verplichtingen (denk vooral aan de verplichtingen uit de Wkkgz) en de regels die intern in het ziekenhuis gelden ('huisregels'). Dit houdt verband met het feit dat het ziekenhuis op grond van de Wkkgz eindverantwoordelijk is voor de kwaliteit van de zorg, met inbegrip van de zorg die ad hoc door de (verpleeg)huisarts wordt verstrekt.

Een aanname bij het voorgaande is dat de handelingen die de (verpleeg)huisarts in het kader van de euthanasie verricht zijn te kwalificeren als 'zorg' in de zin van art. 1 lid 1 Wkkgz. Zij vormen, doordat euthanasie onder het basispakket van de Zvw valt (zorgverzekeraars kunnen deze prestatie in hun modelovereenkomsten overigens wel van vergoeding uitsluiten, zie art. 11 lid 5 Zvw), namelijk 'Zvw-zorg'. Ook lijkt te kunnen worden aangehaakt bij de in artikel 1 lid 1 Wkkgz vermelde categorie 'andere zorg'. Een vérgaande oprekking van de wettelijke terminologie is hiervoor niet nodig, aangezien de hiervoor al genoemde strekking van de Wkkgz (kwaliteitswaarborging) aanleiding geeft om het begrippenpaar 'andere zorg' niet al te strikt te interpreteren en daaronder óók de 'bijzondere zorg' te scharen die bij euthanasie wordt verleend.

\subsection{Toepasselijkheid van afdeling 7.7.5 BW en civielrechtelijke aansprakelijkheid van het ziekenhuis}

Privaatrechtelijk rijst de vraag of het ziekenhuis centraal aansprakelijk kan worden gesteld, op basis van art. 7:462 BW, bij tekortschietend handelen van de (verpleeg)huisarts. Dit is in beginsel het geval, omdat sprake is van een (arts out-)situatie waarop de regeling van de centrale aansprakelijkheid ziet. Tussen het ziekenhuis en de arts bestaat immers géén arbeidsrechtelijke verhouding (arts in-situatie). In dit laatste geval is er de facto overigens ook sprake van een 'centrale' aansprakelijkheid, maar dan op grond van art. 6:76 en 6:170 BW doordat de arts contractueel gezien als een hulppersoon van het ziekenhuis is te beschouwen en buitencontractueel als diens ondergeschikte.

Aansprakelijkstelling is eventueel denkbaar ter verhaal van immateriële schade van de nabestaanden van de patiënt. Per 1 januari 2019 kan dat in beginsel ook affectieschade zijn. Op vragen die de recente wijziging van de art. 6:106-108 BW in dit kader kunnen doen rijzen wordt in dit artikel niet ingegaan. ${ }^{18}$

Een belangrijke voorvraag die het voorgaande oproept, is of bij het toepassen van euthanasie wel een geneeskundige behandelingsovereenkomst tussen de (verpleeg)huisarts en de patiënt tot stand komt, dan wel of een reeds bestaande behandelingsovereenkomst zich ook tot de fase van de euthanasie-orgaandonatie 
uitstrekt. Indien dit niet zo is, kan art. 7:462 BW geen toepassing vinden en vervalt de mogelijkheid tot centrale aansprakelijkstelling van het ziekenhuis. De klassieke, door Leenen geformuleerde opvatting is dat euthanasie geen 'gewoon' medisch handelen is. ${ }^{19}$ Het betreft namelijk geen 'handeling op het gebied van de geneeskunst' zoals in art. 7:446 lid 2 BW omschreven. Daardoor ontbreekt één van de kernvereisten waaraan moet worden voldaan om een overeenkomst als 'overeenkomst inzake geneeskundige behandeling' te kunnen betitelen in de zin van art. 7:446 lid 1 BW. Leenens argumenten zijn vooral gebaseerd op de parlementaire geschiedenis van afdeling 7.7.5 BW. Hij leidt daaruit onder andere af dat de wetgever bij de totstandbrenging van art. 7:446 lid 2 BW niet aan euthanasie heeft gedacht. Consequent doorredenerend acht hij ook analoge toepassing van afdeling 7.7.5 BW met gebruikmaking van de schakelbepaling van art. 7:464 lid 1 BW niet mogelijk nu ook deze bepaling uitgaat van 'handelingen op het gebied van de geneeskunst'.

In reactie op een discussiestuk van Arends in het Tijdschrift voor Gezondheidsrecht (2017) sluit Sijmons zich bij deze visie van Leenen aan. ${ }^{20,21}$ Ook hij doet een beroep op de wetsgeschiedenis. Zijn kernargument is hierbij dat een contractuele gebondenheid van de arts, met een verplichting tot nakoming in de vorm van het uitvoeren van de euthanasie, zich niet verdraagt met het bijzondere karakter van euthanasie: de arts moet tot op het laatste moment de vrijheid (kunnen) behouden om zijn geweten te volgen en zich eventueel terug te trekken. De overeenkomst tussen partijen zou dan ook nietig zijn ingevolge art. 3:40 lid 1 BW wegens strijd met de goede zeden. Sijmons ziet wel ruimte voor analoge toepassing van afdeling 7.7.5 BW, via art. 7:464 lid 1 BW, op de 'schil' van handelingen om de euthanasie heen zoals de keuze en het verschaffen van het euthanaticum en de verslaglegging in het medisch dossier. Het door hem daarvoor genoemde argument is dat de betreffende handelingen sterk in de sfeer van de geneeskunde liggen.

Arends neemt het standpunt in dat euthanasie tegenwoordig tot het reguliere medische domein behoort, waardoor de regels betreffende de overeenkomst van opdracht en, meer specifiek, die inzake de geneeskundige behandelingsovereenkomst van toepassing zijn. ${ }^{22}$ Uit de wetsgeschiedenis van afdeling 7.7.5 BW zou juist volgen dat de wetgever alle door artsen verrichte handelingen onder de omschrijving 'handelingen op het gebied van de geneeskunst' heeft willen brengen.

Met betrekking tot de combinatie euthanasie-orgaandonatie stelt Sijmons, in lijn met zijn hiervoor weergegeven zienswijze, dat het ziekenhuis niet op grond van art. 7:462 BW hoofdelijk aansprakelijk is te stellen voor verrichtingen die door de huisarts, met gebruikmaking van de ziekenhuisfaciliteiten, bij de euthanasie zijn uitgevoerd. Centrale 
aansprakelijkstelling van het ziekenhuis zou evenmin mogelijk zijn voor de handelingen van de huisarts om de euthanasie heen ('schil'), omdat art. 7:462 BW niet - via art. 7:464 lid 1 BW, de bepaling waarbij in het geval van deze handelingen zou worden aangeknoopt - analoog zou kunnen worden toegepast. Wellicht berust deze opvatting op het feit dat artikel 7:462 BW een behandelingsovereenkomst tussen de hulpverlener (in casu: de (verpleeg)huisarts) en de patiënt veronderstelt, in de nakoming van welke overeenkomst de hulpverlener toerekenbaar is tekortgeschoten.

Wij sluiten ons aan bij de visie van Sijmons dat bij euthanasie geen sprake is van een overeenkomst inzake geneeskundige behandeling, omdat deze visie ons inziens het meest strookt met de wetsgeschiedenis en met het karakter van euthanasie. Euthanasie is, naar onze opvatting, nog steeds als een gebeurtenis en een verrichting van bijzondere aard aan te merken. Wel lijkt ons een tweetal kanttekeningen bij Sijmons' benadering op zijn plaats.

De eerste kanttekening is of de omweg van art. 7:464 lid $1 \mathrm{BW}$ wel nodig is om afdeling 7.7.5 BW van toepassing te doen zijn op de handelingen rondom de euthanasiedonatieprocedure ('schil'). Men kan beargumenteren dat deze handelingen geen 'geneeskunst' zijn omdat ze niet ten voordele noch ter genezing van de donerende patiënt worden uitgevoerd. Men kan eveneens stellen dat ze één geheel vormen met de euthanasie als zodanig en juridisch daarom op dezelfde wijze als de euthanasie (geen 'geneeskunst') dienen te worden gekwalificeerd. Wanneer men echter toch ook gewicht toekent aan het feit dat ze in de sfeer van de geneeskunde liggen, en men ze bij de toepassing van art. 7: 464 lid 1 BW (kennelijk) schaart onder de in dit artikel genoemde 'handelingen op het gebied van de geneeskunst' (vergelijk Sijmons), is de stap naar kwalificatie als 'handelingen op het gebied van de geneeskunst' in de zin van art. 7:446 lid 1 en 2 BW klein. Het resultaat zou dan zijn dat bepalingen zoals art. 7:453 en 454 BW (goed hulpverlenerschap, dossierplicht) alsmede art. 7:462 BW rechtstreeks - niet analoog - zijn toe te passen op de verrichtingen van de (verpleeg)huisarts rondom de euthanasie-orgaandonatie. Dit zou de rechtsbescherming van de patiënt, in ieder geval de duidelijkheid daarover (geen constructie via art. 7:464 lid 1 BW; zie met betrekking tot art. 7:462 BW ook de tekst hierna), ten goede kunnen komen. Een voordeel zou ook zijn dat de verrichtingen in de 'schil' rond de euthanasie op deze wijze eenzelfde kwalificatie ten deel zou vallen als de handelingen ter voorbereiding van de orgaandonatie. Die zijn gezien hun medische aard namelijk rechtstreeks (zonder de omweg van art. 7:464 lid 1 BW) te duiden als handelingen op het gebied van de geneeskunst. Verder ontstaat er meer parallellie met de publiekrechtelijke benadering in 
het kader van de Wkkgz; denk aan de ruime omschrijving en invulling van het begrip 'zorg' in art. 1 lid 1 Wkkgz (zie par. 4.2).

De tweede kanttekening betreft Sijmons' (kennelijke) aanname dat art. 7:462 BW zich niet voor analoge toepassing via art. 7:464 lid 1 BW leent. De strekking van art. 7:464 lid 1 BW lijkt ruimte te bieden voor een andere, ruimere, opvatting. Zouden, evenals bijvoorbeeld de patiënt die bewusteloos het ziekenhuis wordt binnengebracht (met eventueel een te verwachten donatieprocedure), de nabestaanden van de patiënt bij wie iets mis is gegaan bij de verrichtingen rondom de euthanasie-donatieprocedure geen gebruik moeten kunnen maken van de voordelen van de regeling van de centrale ziekenhuisaansprakelijkheid? Het eventuele alternatief, dat van een beroep op art. 3:33 jo. art. 3:35 BW (behandelrelatie met het ziekenhuis op grond van door het ziekenhuis opgewekt vertrouwen) is juridisch weinig beproefd en daarom niet aantrekkelijk.

De praktijk leert dat ziekenhuizen uit vrees voor een mogelijke centrale aansprakelijkheid nogal eens terughoudend zijn bij het toelaten van de (verpleeg)huisarts voor het uitvoeren van de euthanasie voorafgaand aan de orgaandonatie. Uit het voorgaande volgt dat deze vrees niet gegrond is indien wordt uitgegaan van de visie van Sijmons (de handelingen in de schil rond de euthanasie daargelaten), wél als wordt aangesloten bij de zienswijze van Arends. De vraag is hierbij of het aansprakelijkheidsrisico wel zo groot is nu relatief (zeer) weinig euthanasiecasus door de regionale toetsingscommissies als onzorgvuldig worden beoordeeld en dit tot nu toe ook het beeld is bij de combinatie euthanasie-orgaandonatie. Bovendien zouden ziekenhuisbestuurders vooral ook oog dienen te hebben voor de aanmerkelijke belangen van niet-financiële aard aan de zijde van de patiënt.

\subsection{Strafrechtelijke aansprakelijkheid}

Indien de regionale toetsingscommissie in een bepaald geval wél van oordeel is dat de euthanasie onzorgvuldig werd uitgevoerd, kan het openbaar ministerie besluiten om tot vervolging over te gaan. De rechter zou vervolgens tot het oordeel kunnen komen dat de uitvoerend arts schuldig is aan het beëindigen van iemands leven op diens uitdrukkelijk en ernstig verlangen (art. 293 Sr).

Theoretisch gezien zouden de bij de euthanasie betrokken zorgverleners alsook het ziekenhuis (als rechtspersoon) en één of meer van zijn bestuurders medeplichtig kunnen zijn (art. 51 lid 1 en 2 Sr). Zij zijn dan namelijk opzettelijk behulpzaam geweest bij het plegen van een misdrijf, of zij hebben hiertoe opzettelijk gelegenheid of middelen verschaft (art. 48 Sr). Volgens art. 49 lid 4 Sr komen voor het bepalen van de straf alleen 
die handelingen in aanmerking die de medeplichtige opzettelijk gemakkelijk heeft gemaakt of bevorderd, benevens hun gevolgen. Waar het deze gevolgen betreft, is niet relevant of het opzet daar mogelijkerwijze niet op was gericht.

De Hoge Raad verlangt dat er sprake is van zogenaamd 'dubbel opzet' en er dus opzet is gericht op het leveren van een bijdrage én op het strafbare feit. Bij euthanasie gevolgd door orgaandonatie leveren zowel het ziekenhuis als de zorgverleners een bijdrage aan de benodigde handelingen die op dat moment tezamen nog als een strafbaar feit zijn te beschouwen, hoewel eenieder vertrouwt op de correcte beoordeling van de zorgvuldigheidseisen door de uitvoerend (verpleeg)huisarts. Het is in de praktijk belangrijk dat men er inderdaad op kan vertrouwen dat deze arts een correcte afweging heeft gemaakt, zodat in een voorkomend geval alleen hij ex post strafrechtelijk aansprakelijk kan worden gesteld. De in par. 4.2 besproken (toelatings)overeenkomst tussen het ziekenhuis en de (verpleeg)huisarts kan een instrument zijn om op voorhand bepaalde kwalificatie vast te leggen waaraan de (verpleeg)huisarts moet voldoen. zoals deskundigheid en ervaring met betrekking tot de euthanasie- en eventueel ook de donatieprocedure.

Mede gelet op de mogelijke juridische implicaties is het niet vreemd dat ziekenhuizen reeds commissies hebben ingericht die de euthanasievraag van een patiënt, wanneer die gecombineerd is met orgaandonatie, een tweede keer beoordelen. Hierdoor werden zelfs al euthanasieverzoeken afgewezen. Het is begrijpelijk dat ziekenhuizen zich wensen in te dekken, maar men lijkt zich zo te bemoeien met de arts-patiëntrelatie en de autonome beslissing die de uitvoerend arts, geadviseerd door de SCEN-arts, bij euthanasie neemt. De gevolgde werkwijze is hierdoor moeilijk te verenigen met het bepaalde in de WTL. Bovendien kan men zich afvragen of zij de mate van verantwoordelijkheid niet juist 'vergroot' in die gevallen waarin de procedure tóch als onzorgvuldig wordt beoordeeld door de regionale toetsingscommissie.

\subsection{Autonomie van de patiënt}

Orgaandonatie na euthanasie wordt door zorgverleners ondersteund en gefaciliteerd opdat de laatste wens van de patiënt ingewilligd kan worden. Tegelijkertijd wordt een positief resultaat bereikt voor een patiënt die op de transplantatiewachtlijst staat. Toch bestaat er nog verschil van opvatting aangaande de informatieplicht jegens de patiënt. Op basis van art. 7:448 BW dient een hulpverlener de patiënt altijd correct te informeren over de voorgestelde behandeling. Het is echter onduidelijk of het noodzakelijk is om de patiënt ook te informeren over de mogelijkheid tot orgaandonatie, ook na euthanasie. 
Bij de combinatie orgaandonatie-euthanasie dient immers extra zorgvuldig te worden gehandeld om te vermijden dat de patiënt zich onder druk gezet voelt om in te stemmen of mogelijk zelfs de indruk krijgt dat hij (eerder) in aanmerking komt voor euthanasie omdat hij zijn organen zal doneren. Tegelijkertijd kunnen familieleden na het overlijden of ook de patiënt zelf indien hij dit ontdekt vóór de euthanasie - ontevreden zijn over het niet vermelden van de mogelijkheid tot orgaandonatie na euthanasie. Illustratief voor deze laatste situatie is, zij het buiten het terrein van orgaandonatie na euthanasie (een onverwacht overlijden na kort tevoren ontstane fysieke klachten) een recent door het tuchtcollege Den Haag beoordeelde casus. Onbekendheid met de donatiewens van de patiënt en onbekendheid van de doodsoorzaak - orgaandonatie is dan in beginsel niet mogelijk - maakten in dit geval dat het tuchtcollege geen verwijtbaar handelen aanwezig achtte bij de huisarts van de betrokken patiënt. ${ }^{23}$

Volgens het principe van autonomie kan de patiënt slechts een weloverwogen besluit nemen indien hij correct en voldoende geïnformeerd is. Toch lijkt terughoudendheid noodzakelijk in deze zeer gevoelige context. De huidige richtlijn inzake orgaandonatie na euthanasie stelt dat de patiënt zelf het voorstel tot orgaandonatie na euthanasie dient te uiten. Indien dit gebeurt voordat het besluit aangaande honorering van het euthanasieverzoek is genomen, behoort de arts het gesprek over dit onderwerp uit te stellen totdat duidelijk is dat aan de zorgvuldigheidseisen van art.2 lid 1 onder a-e Wtl wordt voldaan. Wij zijn van mening dat een arts die deze duidelijkheid heeft verkregen het Donorregister behoort te raadplegen. Deze verplichting kan ook gelezen worden in art. 20 lid 1 WOD dat bepaalt dat men in geval van een gerede kans op overlijden binnen afzienbare tijd dient na te gaan of in het Donorregister een wilsverklaring van de betreffende persoon is te vinden.

Op basis van deze wilsverklaring en de relatie die de arts met de patiënt heeft kan de arts - indien er op dat moment geen contra-indicaties voor orgaandonatie zijn - al dan niet het initiatief nemen om de patiënt te informeren over de mogelijkheid tot orgaandonatie. Zelfs wanneer er een weigering geregistreerd staat, zou het naar onze mening gelegitimeerd kunnen zijn om met de patiënt het gesprek aan te gaan. De omstandigheden, en daarop gestoelde gedachten van de patiënt, kunnen immers geheel anders zijn dan die welke de patiënt ten tijde van het invullen van het donorformulier voor ogen had. De landelijke richtlijn inzake orgaandonatie na euthanasie stelt daarentegen expliciet dat de huisarts niet actief de mogelijkheid van orgaandonatie na euthanasie mag benoemen. 


\subsection{Gekozen ontvanger(s)}

De argumentatie om orgaandonatie na euthanasie mogelijk te maken steunt vooral op het beginsel van autonomie, gecodificeerd in art. $11 \mathrm{GW}$ en ten grondslag liggend aan zowel afdeling 7.7.5 BW als de WOD. Mensen moeten in beginsel te allen tijde zelf over hun lichaam kunnen beschikken, en dus ook de mogelijkheid hebben om hun organen te doneren indien zij voor euthanasie kiezen. Deze lijn doortrekkend kan men ook stellen dat zij de ontvanger(s) van hun organen behoren te kunnen kiezen.

Indien de patiënt die euthanasie wenst een persoon kent die, bijvoorbeeld, een nieuwe nier nodig heeft, dan zou hij bij leven een nier kunnen afstaan aan die persoon, op voorwaarde dat dit orgaan medisch geschikt blijkt voor de ontvanger, ook wat betreft de compatibiliteit (de mate waarin de organen qua weefseltypering overeenkomen). Bij een donatie na overlijden behoort de toewijzing van het orgaan echter te verlopen via het orgaancentrum, zoals bepaald in art. 18 jo. 24 WOD, en wordt de keuze voor een bepaalde persoon of personen als ontvanger(s) niet overgelaten aan de donor. Zoals eerder is besproken door Sijmons, weerspiegelt zich hierin een stelsel van collectief beschikken over organen van een overledene, en niet een individueel beschikken. ${ }^{24}$ Het zou echter zeer onwenselijk zijn als een patiënt die een nier wil doneren aan een specifieke persoon eerst nog bij leven een ingreep zou moeten ondergaan om dit te realiseren alvorens euthanasie te ondergaan en dan zijn overige organen aan onbekenden te doneren.

Het verdient daarom aanbeveling om ook déze vorm van zelfbeschikking wettelijk te faciliteren. Een regel die het - ook buiten de combinatie met euthanasie - mogelijk maakt om iemand aan te aanduiden voor het ontvangen van één of meer van zijn organen zal ook in algemene zin bemoedigen tot het doneren van organen op een moreel nietaanvechtbare wijze. Zij zal echter wel spanning oproepen met het principe van een rechtvaardige verdeling van organen. Gezien dit belangrijke nadeel ligt het in de rede om het toepassingsgebied van een dergelijke regel te beperken tot alleen die patiënten die in een bijzondere situatie (euthanasie) nog iets voor een ander willen betekenen, om zo hun bijzondere wensen in vervulling te kunnen laten gaan en wellicht ook de nabestaanden te sterken op een moeilijk moment.

\subsection{De minderjarige patiënt}

Ook een minderjarige heeft vanaf de leeftijd van twaalf jaren wettelijk gezien de mogelijkheid om euthanasie te ondergaan. Hiervoor dient hij aan dezelfde zorgvuldigheidseisen te voldoen als een volwassene. Indien de minderjarige de leeftijd 
heeft tussen de twaalf en zestien jaren dienen de ouders zich met de levensbeëindiging te kunnen verenigen. Indien hij tussen zestien en achttien jaren oud is, dienen de ouders bij de besluitvorming te worden betrokken (art. 2 lid 3 jo. 4 WTL).

Daarnaast kunnen kinderen van twaalf jaar of ouder toestemming geven voor het verwijderen van hun organen na overlijden (art. 9 lid 1 WOD). Er is dus ook geen wettelijk beletsel tegen het uitvoeren van orgaandonatie na euthanasie bij minderjarigen vanaf twaalf jaar. Theoretisch zou een ouder nog bezwaar kunnen uiten na het overlijden van de minderjarige patiënt jonger dan zestien jaar, maar uitsluitend vóór het uitnemen van de organen (art. 12 WOD). Aangezien er in deze leeftijdscategorie echter ook toestemming van de ouders vereist is voor euthanasie, lijkt dit slechts een hypothetische situatie.

Ook hier neemt de juridische basis niet weg dat het een ethisch en emotioneel zeer gevoelige kwestie is, aangezien alleen al euthanasie bij kinderen vaak moeilijk te aanvaarden is. Toch zou de laatste, weloverwogen wens van de minderjarige patiënt om zijn organen te doneren gefaciliteerd moeten kunnen worden. Er dient hierbij wel opgemerkt te worden dat euthanasie bij minderjarigen heel beperkt voorkomt, en dan met name in geval van een maligniteit. Deze patiënten komen om deze reden niet in aanmerking voor orgaandonatie.

Soms wordt discussie gevoerd over de vraag of euthanasie ook mogelijk dient te zijn voor kinderen jonger dan twaalf. Het is af te wachten hoe de gedachten hierover zich verder ontwikkelen en wat de eisen voor deze categorie dan zouden worden, en ook wat dit zou betekenen voor orgaandonatie na euthanasie bij kinderen. ${ }^{25}$

\subsection{Organ donation euthanasia}

Een potentieel toekomstig dilemma betreft de procedure die in de internationale literatuur ook wel wordt aangeduid met de term organ donation euthanasia (ODE). De patiënt overlijdt dan niet door de euthanasiemedicatie, maar krijgt anesthesie alvorens de organen, inclusief het hart, worden uitgenomen, hetgeen dan het overlijden veroorzaakt. Deze procedure wordt op dit moment ethisch gezien nog als een stap te ver beschouwd.

Vanzelfsprekend is voor ODE slechts plaats indien aan de zorgvuldigheidseisen die gelden voor euthanasie wordt voldaan, en indien de patiënt weloverwogen besluit tot orgaandonatie. De vraag om deze procedure uit te voeren is inmiddels al daadwerkelijk 
door patiënten geuit in de voorbereidende gesprekken rondom orgaandonatie na euthanasie. Hierdoor zouden de organen namelijk in betere staat zijn én is het mogelijk om ook het hart te doneren, iets wat door de donoren belangrijk gevonden wordt, respectievelijk waarom men verzoekt.

Aangezien de patiënt nog leeft wanneer de organen verwijderd worden, dient gesproken te worden over het ter beschikking stellen van organen bij leven. De wet stelt echter duidelijk dat orgaandonatie bij leven die gevolgen heeft voor de gezondheid van de donor slechts mogelijk is indien de ontvanger van 'het' orgaan in levensgevaar verkeert en dit gevaar niet op andere wijze even goed kan worden afgewend (art. 5 lid 1 WOD). Hoewel er nog gediscussieerd zal kunnen worden over het in levensgevaar zijn van een persoon op de transplantatiewachtlijst, heeft de wetgever zich duidelijk gericht op het doneren van één orgaan. In de huidige praktijk gaat het dan meestal over nierdonatie. In de hypothetische situatie van ODE speelt hiernaast dus de gezondheid van de donor een rol bij het doneren van alle mogelijke organen en weefsels.

Er dient geconcludeerd te worden dat ODE momenteel juridisch niet toegestaan is. Door veranderingen in de praktijk van orgaandonatie zal wellicht wel nagedacht moeten worden over wijziging, te zijner tijd, van de wetgeving en daarmee samenhangende richtlijnen aan de nieuwe ontwikkelingen, tenminste wanneer daar voldoende politiek, maatschappelijk, juridisch en ethisch draagvlak voor bestaat. De benodigde aanpassing van de WOD is nog niet opgenomen in wetswijziging (introductie ADR-stelsel) die in 2020 zal ingaan, maar kan mogelijk voor een eerste keer besproken worden bij de wetsevaluatie in $2023 .^{11}$

In ieder geval moet vermeden worden dat het brede publiek de indruk krijgt dat er een 'jacht' op organen bestaat, waarbij zelfs vitale organen kunnen worden uitgenomen bij een levende patiënt. Dit druist in tegen de huidige dead donor rule, die het belang van de donor wenst te beschermen.

\section{Conclusie}

Orgaandonatie na euthanasie is voor patiënten met een euthanasiewens en daarnaast de wens om nog iets voor één of meer anderen te kunnen betekenen een waardevolle procedure. Voor patiënten op een wachtlijst voor transplantatie is ieder (extra) orgaan dat ter beschikking komt levensreddend. De wetgeving verzet zich niet tegen een combinatie van beide procedures, zelfs niet bij minderjarigen vanaf twaalf jaar. Hierdoor 
heeft deze combinatie de afgelopen jaren in toenemende mate ingang gevonden in de medische praktijk. Zij werd in Nederland al minstens 50 keer uitgevoerd. Er dient echter verder gedebatteerd te worden over de juridisch-ethische dilemma's rondom orgaandonatie na euthanasie, zoals het informeren van de patiënt die euthanasie zal ondergaan over de mogelijkheid tot orgaandonatie en het uitnemen van de organen bij een patiënt onder algehele anesthesie (ODE). Het is in dit kader uitermate belangrijk om het recht op autonomie van de patiënt te respecteren en zijn laatste wens waar mogelijk in te willigen. Nieuwe ontwikkelingen zoals ODE zullen in de toekomst aanleiding kunnen zijn om de wetgeving (verder) te overdenken en mogelijk tot een wijziging daarvan over te gaan. 


\section{Referenties}

1. Bollen J, Ten Hoopen R, Ysebaert D, van Mook W, van Heurn E. Legal and ethical aspects of organ donation after euthanasia in Belgium and the Netherlands. J Med Ethics 2016;42(8): 486-9.

2. Van Raemdonck G, Dupont L, Ysebaert D, Monbaliu D, Neyrinck A, Coosemans W, Decaluwe $H$, De Leyn $P$, Nafteux $P$, Lerut $T$. Initial experience with transplantation of lungs recovered from donors after euthanasia. Appl Cardiopulm Pathophysiol 2011;15:38-48.

3. Bollen J, van Smaalen T, Ten Hoopen R, van Heurn E, Ysebaert D, van Mook W. Potential Number of Organ Donors After Euthanasia in Belgium, JAMA 2017;317(14):1476-7.

4. Bollen JAM, Shaw D, de Wert G, Ten Hoopen R, Ysebaert D, van Heurn E, van Mook W. Euthanasia through living organ donation: Ethical, legal, and medical challenges. J Heart Lung Transplant. 2019;38(2):111-113.

5. Richtlijn Orgaandonatie na Euthanasie. Nederlandse Transplantatiestichting, versie 1.2, november 2017, te raadplegen via https://www.transplantatiestichting.nl/bestel-endownload/richtlijn-orgaandonatie-na-euthanasie.

6. van Smaalen T, et al., Orgaandonatie na euthanasie. Huiarts en Wetenschap, Uitgave 2/2018.

7. Gezondheidsraad, Modelprotocol Postmortale orgaan- en weefseldonatie, versie 1.1 - januari 2019, te raadplegen via https://www.transplantatiestichting.nl/sites/default/files/ modelprotocol_postmortale_orgaan-_en_weefseldonatie.pdf.

8. Bollen J, de Jongh W, Hagenaars J, van Dijk G, Ten Hoopen R, Ysebaert D, ljzermans J, van Heurn E, van Mook W. Organ Donation After Euthanasia: A Dutch Practical Manual. Am J Transplant. 2016;16(7):1967-72.

9. Oordeel 2017-18, Regionale Toetsingscommissies Euthanasie, Te raadplegen: https://www.euthanasiecommissie.nl/uitspraken/publicaties/oordelen/2017/consultatie/oor deel-2017-18.

10. Regionale Toetsingscommissies Euthanasie, EuthanasieCode 2018: De toetsingspraktijk toegelicht, april 2018, te raadplegen via https:/www.euthanasiecommissie.nl/binaries/ euthanasiecommissie/documenten/brochures/brochures/euthanasiecode/2018/euthanasiec ode2018/EuthanasieCode2018.pdf.

11. Gevers JKM. De herziening van de Wet op de orgaandonatie: een terugblik, Tijdschrift voor Gezondheidsrecht 5 (2018) 387-400.

12. Kamerstukken Eerste Kamer der Staten-Generaal, 33.506 Initiatiefvoorstel-Pia Dijkstra over het opnemen van een actief donorregistratiesysteem, te raadplegen via https://www.eerstekamer.nl/wetsvoorstel/33506_initiatiefvoorstel_pia.

13. Kompanje EJO. Automatische Donor Registratie: een ultieme poging om meer witte raven te vangen?, Tijdschrift Zorg \& Recht in praktijk, SDU, nummer 1, januari 2017.

14. Brief van de minister van Volksgezondheid, Welzijn en Sport inzake het voorstel van wet van het lid Pia Dijkstra tot wijziging van de Wet op de orgaandonatie in verband met het opnemen van een actief donorregistratiesysteem, Eerste Kamer, vergaderjaar 2017-2018, 33 506, K, te raadplegen via https://www.eerstekamer.nl/behandeling/20170921/ brief_van_de_minister_van_vws_ter/document3/f=/vkhubdf94hlh.pdf.

15. Antwoorden op Kamervragen van Arib en Tellegen, $2015 Z 02563$ en 2015Z02564, 4 maart 2015.

16. Gezondheidsraad, Vaststellen van de dood bij postmortale orgaandonatie, 10 juni 2015, te raadplegen via https://www.gezondheidsraad.nl/documenten/adviezen/2015/06/10/ vaststelling-van-de-dood-bij-postmortale-orgaandonatie. 
17. Een andere opvatting is mogelijk (de tekst is weinig helder en lijkt zichtzelf tegen te spreken) af te leiden uit Nederlandse Transplantatiestichting. Richtlijn Orgaandonatie na euthanasie, Deel 2, Achtergronden, p. 55.

18. Stb. 2018, 133 Besluit vergoeding affectieschade.

19. Zie ook H.J. J. Leenen en J.K.M. Gevers, Handboek gezondheidsrecht, Deel I, Rechten van mensen in de gezondheidszorg, Houten/Diegem: Bohn Stafleu Van Loghum 2000:185-6.

20. Arends LAP. 'Discussie: euthanasie onder de WGBO. I De euthanasieovereenkomst: nonexistent of een juridische werkelijkheid?', TvGR 2017, p.399- 405. Zie ook 'Vervolg discussie: euthanasie onder de WGBO. Naschrift L.A.P. Arends', TVGR 2017:566-9.

21. Sijmons JG. 'Discussie: euthanasie onder de WGBO. II De onmogelijke euthanasieovereenkomst: geen geneeskundige behandelingsovereenkomst', TvGR 2017, p. 406-410. Zie ook 'Vervolg discussie: euthanasie onder de WGBO. Naschrift J.G. Sijmons,', TvGR 2017:569-71.

22. Arends LAP. Discussie: euthanasie onder de WGBO, Tijdschrift voor Gezondheidsrecht 6 (2017) 399-405.

23. RTG Den Haag 11 december 2018, ECLI:NL:TGZRSGR:2018:194.

24. Jaap Sijmons, Beschikken over organen na overlijden: organen als collectieve nalatenschap, NTBR "De dood en het privaatrecht", september 2013, jaargang 30, afl. 7, p. 259-266.

25. Meijer OA. Wilsbekwaam maar te jong? Over euthanasie bij wilsbekwame kinderen jonger dan twaalf jaar, TVGR, aflevering 7, 2016. 
Orgaandonatie na euthanasie: juridische overwegingen en vraagstukken 


\section{(1)}

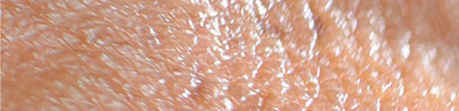

and
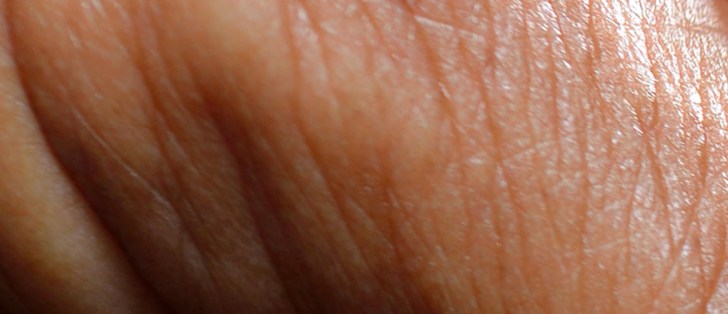

sistet

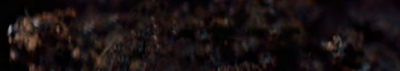

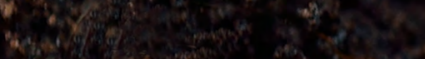

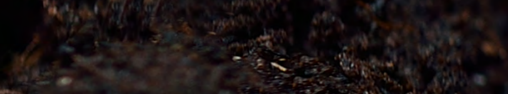

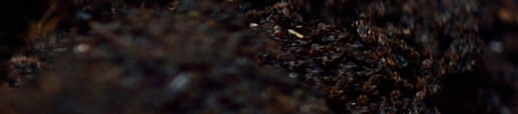
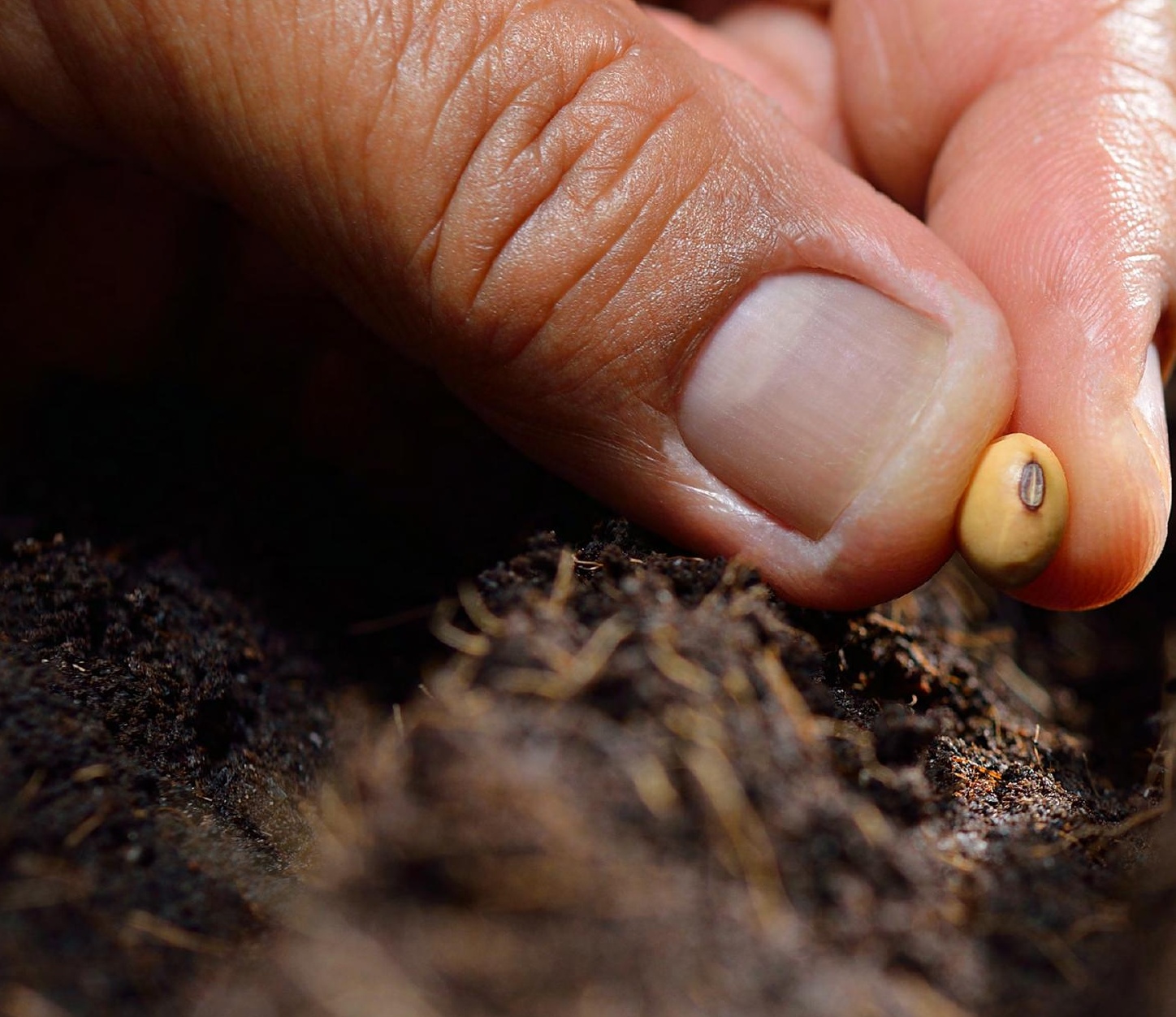

(1) ats
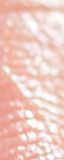

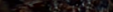
$-2 x^{2}+2 x$

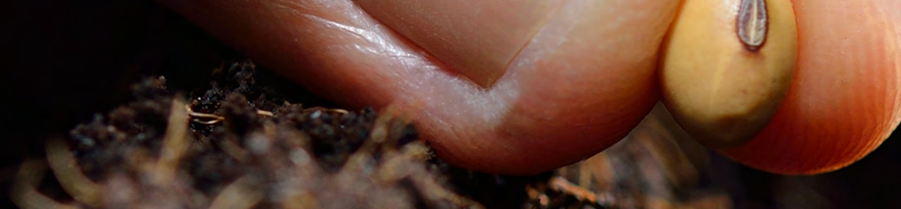




\section{Potential number of organ donors}

after euthanasia in Belgium

Jan Bollen, Tim van Smaalen, Rankie ten Hoopen, Ernst van Heurn, Dirk Ysebaert, Walther van Mook Journal of the American Medical Association (JAMA). 20I 7;3 I 7(I /4): I 476-I 477 


\section{Abstract}

\section{Background}

Organ donation after euthanasia is becoming legally, medically and ethically accepted in Belgium, Canada and the Netherlands. Since 2005, more than seventy people have been able to successfully donate their organs after undergoing euthanasia, thereby fulfilling their last wish. Several thousand people undergo euthanasia each year, but it is unclear how many people are able and willing to donate their organs.

\section{Methods}

We reviewed the Belgian data on euthanasia of 2013, 2014 and 2015, selecting those patients who could be medically suitable to donate organs.

\section{Results}

It is demonstrated that, although many patients are not medically suitable, an estimated $10,2 \%$ of patients who undergo euthanasia are possibly medically suitable to donate at least one organ.

\section{Conclusions}

Though not its primary purpose, organ donation after euthanasia could, have a significant impact on transplant waiting lists. However, potential donors still have to be willing to donate and to die in hospital. 


\section{Introduction}

Solid organ transplantation is the preferred treatment for patients with end stage organ failure. $^{1-3}$ In the Eurotransplant region, waiting lists have decreased slightly over the last 5 year largely due to living related donation, while the total donation rate have not changed significantly. ${ }^{4,5}$ A relatively new and unknown form of organ donation is donation after euthanasia. A patient who fulfills all due diligence criteria undergoes euthanasia, after which his organs are procured by an independent surgical team, according to a Donation after Circulatory Death (DCD) procedure. ${ }^{6}$ They can donate lungs, kidneys, liver and pancreas. Preliminary results reveal good transplant outcomes. ${ }^{7}$ For patients in Belgium, the Netherlands and Canada, it is legally and medically possible to donate organs after undergoing euthanasia. ${ }^{8,9}$

Transplant coordinators state that the number of patients who undergo euthanasia and the number of patients who also want to donate their organs is increasing. ${ }^{10}$ The exact number of potential donors is unknown. In Belgium the number of euthanasia cases increased from 235 in 2003 (0.2\% of all deaths) to 1807 in 2013 (1.7\% of all deaths). ${ }^{11-13}$ The potential impact of organ donation after euthanasia as reflected by actual euthanasia statistics can provide insight for both policy makers and medical professionals. Depending on the number of potential donors, multidisciplinary protocols should be developed, medical professionals need to be informed, and sufficient finances have to be provided to enable this type of donation, since it will put pressure on the current independent surgical transplant teams. ${ }^{14}$

In this article, the Belgian data on euthanasia from 2013 to 2015 are reviewed. These data are compared with the in- and exclusion criteria for possible organ donation to determine how many patients undergoing euthanasia may be medically suitable per year.

\section{Euthanasia}

(Active) euthanasia is the practice where a physician intentionally ends the life of a patient who has voluntarily requested this. It is a developmental, longitudinal and sometimes iterative process of dialogue between the treating physician and the patient. During this period, different alternative support and treatment options are discussed, like palliative sedation, pain relief and hospice care. An extensive report about the legal conditions for euthanasia is beyond the scope of this article, but it is essential that the euthanasia process is strictly separated from the donation procedure. 
According to the Belgian Euthanasia Act, a physician can perform euthanasia on a mentally competent person if this person requests this voluntarily and repeatedly, and the decision has been well considered. ${ }^{15,16}$ The patient must be in a medically hopeless condition and needs to be in a state of constant and unbearable physical or psychological suffering. A second physician consults the patient to check whether the due diligence criteria are fulfilled. When a patient suffers from a disease that will not cause him to die in the near future, a period of at least one month needs to pass before euthanasia can be performed. This can occur at the patient's home, with relatives or friends present, without any external (time) pressure.

\section{Donor registry in Belgium}

A physician who has the intention to perform organ donation on a patient has to check the national registry, and with available relatives whether the patient has expressed the wish not to be an organ donor. ${ }^{17,18}$ In 2016, only 190964 people were registered as 'contra' in the Belgian national registry, while 247235 people had confirmed the presumption of being an organ donor. ${ }^{19}$ Given the fact that Belgium has around 11 million inhabitants, one could state that nearly everyone wants to be an organ donor, and actual refusal is a rarity. The registered reason for not performing organ donation after the patient has died is most often a medical contraindication or refusal by the family of the donor. In the case of organ donation after euthanasia, the patient himself is able to decide and express whether or not he wants to be an organ donor after euthanasia.

\section{Materials and methods}

To evaluate the potential of organ donation after euthanasia the possibility of gaining access to the Belgian euthanasia data was explored. Dutch euthanasia records are kept confidential by law, making it impossible to obtain and analyze these data.

Every two years, the Belgian federal control and evaluation committee on euthanasia publishes a report to inform the Parliament. The number of euthanasia cases, the relative contribution of each cause of suffering in categories, and the distribution over the different age groups (every decade) are mentioned. However, in this report, it is likewise not possible to match the cause with the age group of an individual case. 
For this study, the Belgian Federal Control and Evaluation Committee has granted permission to access more detailed anonymized data of all euthanasia cases from 2013 to 2015. For each individual patient these data were used to extract sex, cause of suffering (categorized), and age category.

Cause of suffering was categorized as follows: cancer, neuromuscular degenerative disease, neuromuscular non-degenerative disease, lung disease, cardiovascular disease, kidney disease, digestive-tract disease, AIDS/HIV, neuropsychological disease, 'multiple pathologies' and 'other pathologies' and marked by either a yes or no. Every patient was assigned to one category. In many cases the data described which disease(s) the patient was suffering from. For the categories 'multiple pathologies' and 'other pathologies' this often included (a combination of) diseases with high risk of organ injury, or diseases with high risk of donor-to-recipient disease transmission, such as infectious diseases. Age groups were categorized per decade, e.g. 20-29 years etc., up to 100 years of age, with the exception of the youngest category 0-19 years.

\section{Outcome measures}

The primary outcome measure was the number of donors which theoretically could donate at least one organ. Subgroup analysis was performed to evaluate the number of potential donors per organ type.

\section{In- and exclusion criteria}

The first exclusion criterion was based on data not being sufficiently detailed for analysis. Other exclusion criteria were currently used contraindications for donation and age criteria within the Eurotransplant region. ${ }^{20}$

Cancer was an exclusion criterion as the majority of malignancies are a contraindication for organ donation. Although not an absolute contraindication, patients with AIDS or HIV were excluded, since organs of these patients are only very rarely accepted. Patients with 'multiple pathologies' were excluded, because they would be unlikely to be accepted as an organ donor for medical reasons. Patients with 'other pathologies' were excluded, because many of these pathologies are usually contraindications for donation (e.g. infectious disease), whereas in others, data were unclear regarding the nature of these pathologies. For subgroup analysis, patients with renal disease were excluded as potential kidney donors, and patients with lung disease as potential lung donors. 
Within the Eurotransplant region, 75 years is the maximum age for donation of kidneys, lungs and for pancreas islet isolation for Maastricht category 3 deceased donors. Therefore, for practical purposes, the category 70-79 years was included while the number of patients in this age category was multiplied by 0.6 (equal to 6 of 10 acceptable age years in this category), assuming an equal distribution of the number of patients. For subgroup analysis of potential liver donors a maximum age of 60 years was used, and for whole pancreas donors 50 years.

\section{Results}

Figure 5.1 shows the in- and exclusion flowchart. From the Belgian review committee 5772 reports of euthanasia from 2013 to 2015 were obtained, of which 15 (0,3\%) were excluded due to insufficient data. Of the remaining 5757 cases, 4547 patients (79\%) were excluded on the basis of a contraindication for organ donation related to their cause of suffering. This included 3930 patients $(68,3 \%)$ due to cancer, 5 patients $(0,1 \%)$ due to AIDS or HIV, 488 patients (8,5\%) categorized as having "Multiple pathologies" and $124(2,2 \%)$ categorized as having "Other pathologies". Thereafter, 499 patients were excluded because of an age older than 80 years and 123 patients comprising $4 / 10$ of the group of $70-79$ years. A total of $588(10,2 \%)$ potential donors with at least one suitable organ for donation remained.

Of the total of 588 potential donors, 10 patients suffering from kidney disease were excluded from kidney donation, which results in 578 possible kidney donors (1156 kidneys). For lung donation 88 patients were excluded leaving 500 potential lung donors. 365 patients older than 60 years were excluded, leaving 223 potential liver donors. For whole pancreas donation, 137 remaining patients older than 50 years were excluded, resulting in 86 potential pancreas donors. 


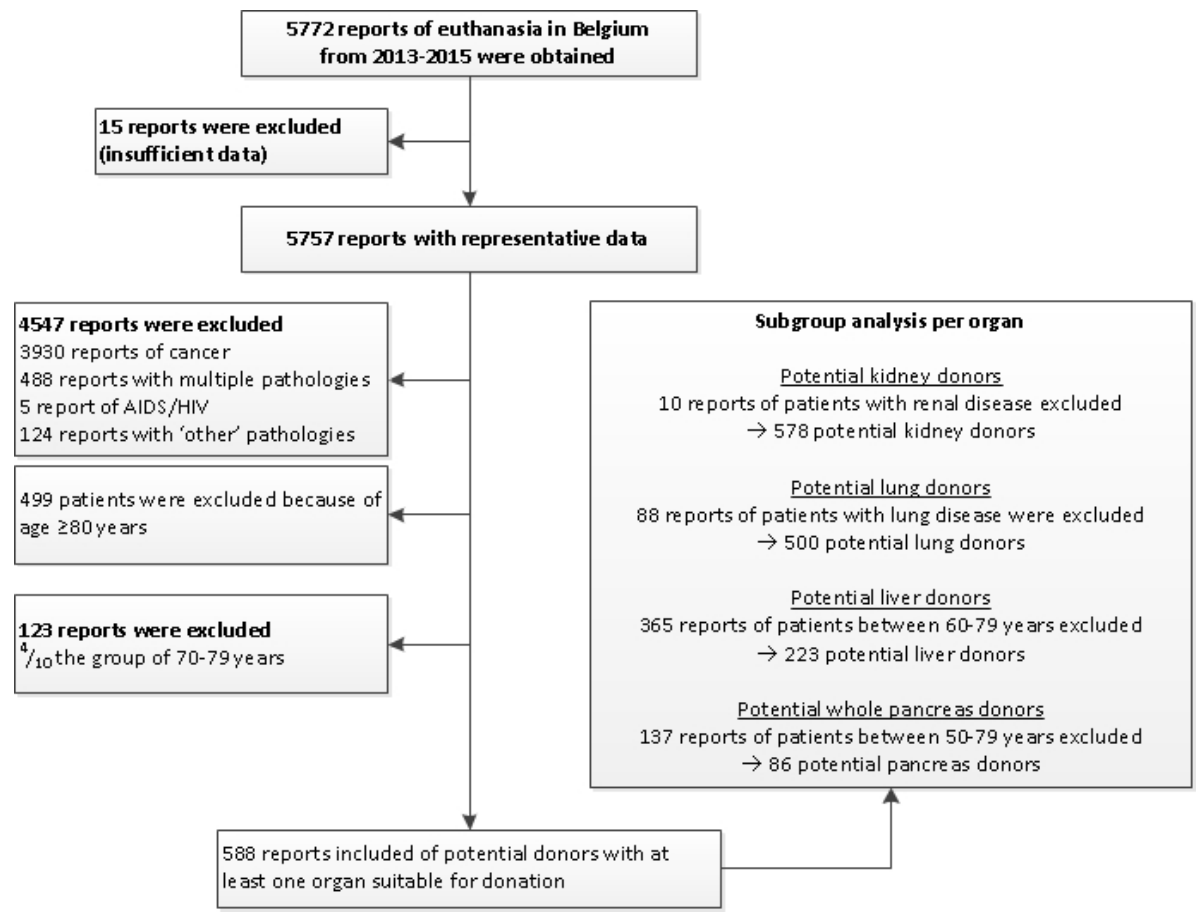

Figure 5.1 In- and exclusion flowchart. First exclusion performed by quality of data reports. Thereafter, medical suitability was verified by using contraindications and age criteria as used in the Eurotransplant region. Subgroup analysis, using organ related contraindications and age criteria, resulted in different numbers of potential donors per organ type.

\section{Discussion}

Organ donation after euthanasia is only possible in a limited number of patients, depending on the cause of suffering and age, and can consequently not be seen as a solution for long waiting lists. ${ }^{23}$ The only goal is to enable patients to carry out their last will, and to donate organs after their own death to help others survive and improve their quality of life. Although the absolute number of organ donors after euthanasia is relatively limited, these donations will nevertheless have an impact on waiting lists. The Dutch guideline states that it is unethical to actively promote organ donation after euthanasia or to ask for donation if a patient has expressed a wish to undergo euthanasia. In Belgium, brochures about organ donation after euthanasia exist, but patients are not actively informed by their physician. 


\section{Potential impact in numbers}

So far, it was assumed that 5.0 to $9.5 \%$ of all euthanasia cases would be eligible to donate their organs. The current study reveals that, assuming ideal circumstances, an estimated maximum of $10,2 \%$ of all patients undergoing euthanasia in Belgium could potentially donate at least one organ. This would result in an addition of 1156 donor kidneys to the donor pool, which in 2017 consisted of 260 kidneys used for transplantation from deceased donors. However, this potential increases the donor pool more than fourfold, a percentage that clearly never will be fully met, because not all patients who undergo euthanasia and who are medically suitable for organ donation will choose to donate.

In 2016, 6091 people underwent euthanasia in the Netherlands. If, similar to the situation in Belgium, 10,2\% of donors were suitable for donation, this would result in 621 potential donors per year. Presuming that approximately one third of the patients and/or relatives currently choose for donation after they have died, the resulting percentage of potential donors who actually become an organ donor will consequently be lower.

\section{Ethical aspects}

One could argue that a physician, who is confronted with a patient who fulfils the due diligence criteria for organ donation, and who does not have any clear contraindications for organ donation, could raise the possibility of organ donation after euthanasia. This would correctly inform the patient who is not aware of this possibility, and may avoid frustration of relatives who find out after the euthanasia procedure that a possibility for organ donation existed. On the other hand, raising the possibility of donating organs after euthanasia might jeopardize the relationship between a patient and his treating physician which could even influence the decision regarding whether to choose euthanasia. However, on the basis of the right to self-determination, physicians should fully cooperate when a patient him or herself expresses his or her last wish to donate organs after undergoing euthanasia. This position statement is harder to defend when the patient is suffering from a mental illness, while euthanasia because of psychiatric suffering in se is already under heavy debate. Therefore, this group of patients is always evaluated by a psychiatrist. ${ }^{21}$

It should also be acknowledged that organ donation after euthanasia needs to be performed within a hospital and after certain preparatory diagnostics have been performed. This creates an extra (emotional and physical) burden for those who wish to 
undergo euthanasia followed by organ donation. During this procedure it is essential to carefully guide patients and discuss this extra burden, and if considered acceptable by the patient, attempt to minimize it when and wherever possible. In many cases of donation after euthanasia, it was the physicians' and transplant coordinators' perception that the donor as well as his relatives were relieved that the possibility of organ donation was given careful consideration, and in some cases proved possible and was actually performed. This gratitude and appreciation regarding the respecting of this final wish outweighed the burden of the necessity for hospital attendance and preparatory investigations. The thought of doing good and contributing to increasing other patients' quality of life and life expectancy added greatly to this.

In contrast to deceased donation, consent is less of an obstacle. The mentally capable patient can request organ donation himself, compared to the situation where his wish is unclear and he is unconscious. Medical suitability only implies that a patient may be a possible organ donor. Not every patient wants to donate organs after death, presuming he or she has already even given thought to this question. When considering the number of patients that could be a possible organ donor, one firstly has to ascertain whether the patient has the will to donate and secondly whether the patient is also willing to die in a hospital. One needs to respect the explicit wish to die at home - and thus not continuing the donation wish, as it would be unethical to put extra pressure on these patients by trying to persuade them.

\section{Limitations of this study}

A limitation to our population based estimation relates to medical suitability. Estimations are drawn from general records regarding euthanasia, which were not primarily intended for more detailed analysis. Patients are only excluded based on contraindications as registered in these records. Given our extensive experience with DCD donors, and with our so far relatively limited experience in organ donation after euthanasia, it could be expected that the number of potential donors will drop significantly if donor screening is performed adequately. On the other hand, it might be expected that more organs will be accepted since these donors are different from the 'general organ donating population'. DCD is mostly performed by withdrawal of life sustaining therapy in the intensive care unit and such patients have suffered from injury or disease during the days or weeks before donation, compared to donors after euthanasia, who are often still active but suffer from e.g. multiple sclerosis (MS) or Amyotrophic lateral sclerosis (ALS). Another limitation is the fact that an equal distribution of patients in the age category 70-79 was assumed in calculating the number 
of eligible donors, which may result in a small overestimation of the number of potential donors as euthanasia more often done on older patients.

\section{Conclusions}

In this analysis of Belgian data on euthanasia in order to explore the potential of organ donation after euthanasia, it is demonstrated that an estimated maximum of $10.2 \%$ of all Belgian euthanasia cases may be medically suitable patients for organ donation. In all probability, the actual numbers will be lower, because many of these potential donors will have contraindications for donation, though this was not clearly documented in the available data. ${ }^{22}$ Furthermore, it is unclear whether patients who want to donate organs are willing to undergo preparatory investigations and are willing to die in the hospital. However, even if only a small percentage of these initial $10.2 \%$ of potential donors remains, this can theoretically have substantial impact on the number of organ donations and on the length of waiting lists, contributing to patients' improved survival with increased quality of life. 


\section{References}

1. Wolfe RA, Ashby VB, Milford EL, et al. Comparison of mortality in all patients on dialysis, patients on dialysis awaiting transplantation, and recipients of a first cadaveric transplant. $\mathrm{N}$ Engl J Med 1999;341(23):1725-30.

2. Tonelli $\mathrm{M}$, Wiebe $\mathrm{N}$, Knoll G, et al. Systematic review: kidney transplantation compared with dialysis in clinically relevant outcomes. Am J Transplant 2011;11(10):2093-109.

3. Saidi RF, Hejazii Kenari SK. Challenges of organ shortage for transplantation: solutions and opportunities. Int J Organ Transplant Med 2014;5(3):87-96.

4. Shaw DM. Organ donation after assisted suicide: a potential solution to the organ scarcity problem. Transplantation. 2014;98(3):247-51.

5. Eurotransplant, Annual Report 2016, Chapter 4: Donation, waiting lists and transplants, The Hague - Accessible: https://www.eurotransplant.org/cms/mediaobject.php?file= Eurotransplant + JV+PDF.pdf.

6. Kootstra G, Daemen JH, Oomen AP. Categories of non-heart-beating donors. Transplant Proc 1995;27(5):2893-4.

7. Van Raemdonck D, Verleden GM, Dupont L, Ysebaert D, Monbaliu D, Neyrinck A, Coosemans W, Decaluwe H, De Leyn P, Nafteux P, Lerut T. Initial experience with transplantation of lungs recovered from donors after euthanasia. Applied Cardiopulmonary Pathophysiology. 2011;15:38-48.

8. Allard J, Fortin MC. Organ donation after medical assistance in dying or cessation of lifesustaining treatment requested by conscious patients: the Canadian context. J Med Ethics 2017;43(9):601-5.

9. Bollen J, Ten Hoopen R, Ysebaert D, van Mook W, van Heurn E. Legal and ethical aspects of organ donation after euthanasia in Belgium and the Netherlands. J Med Ethics 2016;42(8):486-9.

10. Personal communication.

11. Federal monitoring and evaluation committee on euthanasia, First report to the legislative chambers, June 22, 2004.

12. Federal monitoring and evaluation committee on euthanasia, Seventh report to the legislative chambers, 2014-2015, August 09, 2016.

13. Cohen J, Van Landeghem P, Carpentier N, Deliens L. Public acceptance of euthanasia in Europe: a survey study in 47 countries. Int J Public Health 2014;59(1):143-56.

14. Bollen J, de Jongh W, Hagenaars J, et al. Organ Donation After Euthanasia: A Dutch Practical Manual. Am J Transplant 2016;16(7):1967-72.

15. Euthanasia Act (Belgium), May 28, 2002 [Wet betreffende de euthanasie].

16. The Belgian act on euthanasia of May, 28th 2002. European journal of health law. Sep 2003;10(3):329-35.

17. Detry O, Van Deynse D, Van Vlierberghe H, Pirenne J. Organ Procurement and Transplantation in Belgium. Transplantation 2017;101(9):1953-5.

18. Organ Donation Act (Belgium), Article 10 sub 1, June 13, 1986 [Wet betreffende het wegnemen en transplanteren van organen]. 
19. Section Belgian transplant coordinators, Donor \& Transplant statistics, BTS 2016, Accessible: https://www.health.belgium.be/sites/default/files/uploads/fields/fpshealth_theme_file/bts__donor_and_transplant_statistics_2016.pdf.

20. Eurotransplant Manual, Chapter 9: The Donor, version 6.0 October, 2017 - Accessible: https://www.eurotransplant.org/cms/mediaobject.php?file=H9+The+Donor\%2C+september +20171.pdf.

21. Thienpont L, Verhofstadt M, Van Loon T, Distelmans W, Audenaert K, De Deyn PP. Euthanasia requests, procedures and outcomes for 100 Belgian patients suffering from psychiatric disorders: a retrospective, descriptive study. BMJ Open 2015;5(7):e007454.

22. van Smaalen TC, Krikke C, Haveman JW, van Heurn LW. Successful kidney and lung transplantation from a deceased donor with blunt abdominal trauma and intestinal perforation. Transplant Direct 2016;2(1):e55. 


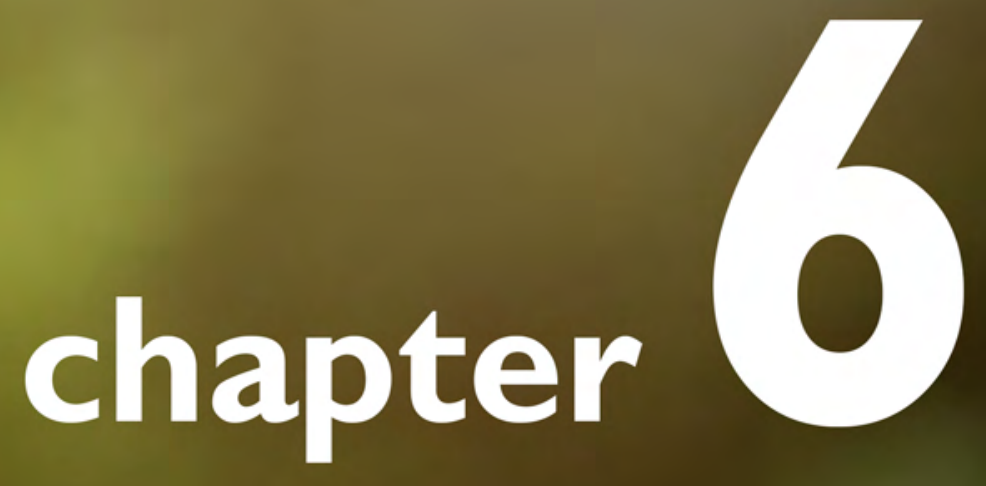

\section{Promising results of}

kidney transplantation from donors following voluntary euthanasia

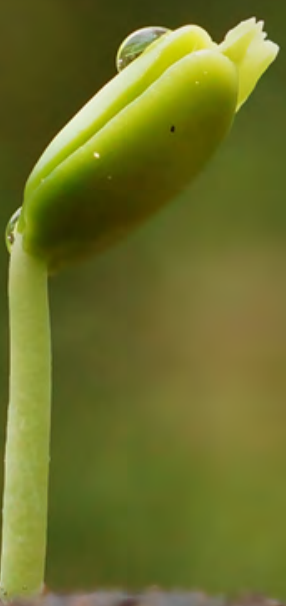

J.A.M Bollen, M.G.J.Snoeijs, M.M. ten Hoopen, D. Shaw J. Kox, D. Ysebaert, W.N.K.A. van Mook, L.W.E. van Heurn 


\section{Abstract}

\section{Background}

A shortage of donor kidneys for transplantation persists. Although performed in a limited number of countries, organ donation after voluntary euthanasia may provide a significant number of organs to patients on the wait lists for transplantation. The clinical outcome of kidneys donated after euthanasia is unclear.

\section{Methods}

Data from all kidney transplantations from deceased organ donors in the Netherlands from 2012 to 2017 were obtained from a national registry. Postoperative graft function, estimated glomerular filtration rate, and death-censored graft and recipient survival of kidneys from donors after euthanasia were compared with the results of kidneys from donors after brain death and circulatory death using multivariable regression analysis.

\section{Results}

Seventy three kidneys from donors after euthanasia were transplanted. The incidence of primary non-function was $7 \%$ and did not differ between donor types. The incidence of immediate graft function in kidneys from donor after euthanasia was 70\%, which was similar to kidneys from donors after brain death $74 \%, \mathrm{P}=0.56)$ and higher than kidneys from donors after circulatory death $(44 \%, \mathrm{P}<0.001)$. Death-censored graft survival was $93 \%$ and recipient survival was $95 \%$ at 1 year after transplantation and was comparable to kidneys from donors after brain death and circulatory death.

\section{Conclusions}

Kidney transplantation following organ donation after euthanasia is associated with good short-term and mid-term clinical outcomes, comparable to kidneys from donors after brain death, and can safely be implemented in countries where legal and ethical requirements have been met. 


\section{Introduction}

Kidney transplantation remains the treatment of choice for the majority of patients with end stage renal failure. ${ }^{1-3}$ Despite the increasing use of organs from living and suboptimal donors, including donors after circulatory death and expanded criteria donors, the gap between the demand and availability of kidneys for transplantation remains substantial. ${ }^{4,5}$ Organ transplantation from donors who died after euthanasia may increase the number of donor organs and thus aid in narrowing this gap. This article only discusses voluntary euthanasia, in which a hopelessly and unbearably suffering, competent patient voluntarily requests euthanasia.

Euthanasia is currently allowed in a limited number of countries: Belgium, Luxembourg, The Netherlands, Colombia and Canada. ${ }^{6-8}$ In these countries an increasing number of patients who choose to undergo euthanasia, actively ask to donate their organs. It is likely that in the future more countries may permit medical assistance for dying in patients with hopeless and unbearable suffering and that the question of organ donation after euthanasia may be raised more frequently. Recently, the ethical, legal and logistical implications of donation after euthanasia have been extensively discussed in both the scientific literature and public media. ${ }^{6,7}$ In addition, recent research demonstrated that approximately $10 \%$ of all patients undergoing euthanasia might be suitable organ donors. $^{9}$

The outcome of organs transplanted following euthanasia is still unknown. The dying process of patients undergoing euthanasia differs from patients who donate their organs following brain or circulatory death. ${ }^{10}$ The current article provides the results of kidneys transplanted following organ donation after euthanasia compared to kidney transplants from other forms of donation.

\section{Methods}

\section{Study population}

We retrieved data from the Dutch Transplant Society Registry, in which the anonymous data of all transplanted patients in the Netherlands are collected. After approval of our study design by the Transplant Registry Board, the data of all patients who underwent kidney transplantation in the Netherlands between January 2012 and December 2017 were obtained. 
Kidneys from pediatric ( $<18$ years) donors or transplanted in pediatric recipients were excluded from the study since organ donation and transplantation after euthanasia is only performed in adults. Uncontrolled donation after circulatory death donor kidneys were excluded (Maastricht Category 1 and 2), since organ donation after euthanasia is a 'controlled' donation, which best can be compared with Maastricht Category 3 donation. ${ }^{11}$

\section{Definitions}

Cases that resulted in non-viable kidneys, in permanent non-function, or graft loss within 7 days were categorized as primary non-function (PNF). Delayed graft function (DGF) was present if dialysis was necessary after transplantation (including dialysis for hyperkalaemia). Expanded criteria donors (ECD) were defined as donors aged 60 years or older, or over 50 years suffering from at least two out of three risk factors: cerebrovascular accident, hypertension or having a serum creatinine $>1.5 \mathrm{mg} / \mathrm{dl}^{.}$

Warm ischemia time (WIT) is defined as the time from cardiac arrest to cold flush or regional perfusion. Cold ischemia time (CIT) is the period between organ procurement and the moment of reanastomosis. Anastomosis time is defined as the time between the end of the cooling period to successful renal artery anastomosis and perfusion of the donor kidney.

\section{Study outcomes}

The outcome parameters were (1) short term graft function, defined as immediate graft function, delayed graft function or primary non-function, (2) death censored graft survival, (3) glomerular filtration after 3 months, one and two years, and (4) recipient survival.

\section{Statistical analysis}

The first and second author analysed the data. Causes of donor death were categorized into three groups. The trauma group included patients who died following an accident or suicide, the vascular group included those suffering from atherosclerotic vascular disease (including hypertension and diabetes), while the 'other' group included e.g. those suffering from a brain tumour, respiratory problem or meningitis. Even though all donors in the euthanasia group died because of physician assisted death, physicians are legally obliged to register the initial pathology as the cause of death. 
The primary diagnosis of the recipient, the kidney disease the patient was suffering from, was categorized into two groups. The vascular group included diseases with a vascular pathology, e.g. glomerulonephritis, IgA vasculitis, diabetes, focal segmental glomerulosclerosis, different types of nephropathy and renal vascular disease. The 'other' group included - amongst others - traumatic loss of kidney, pyelonephritis or interstitial nephritis, polycystic kidneys and hereditary kidney diseases.

Continuous variables are presented as mean and standard deviation or as median and interquartile range depending on data distribution. Categorical variables are presented as percentages. Mann-Whitney $U$ tests were used for comparison of continuous variables. Chi-squared tests were used for comparison of categorical variables. Graft and recipient survival were estimated with Kaplan-Meier curves and compared with log-rank tests. Graft survival was censored for recipient death with a functioning graft. For multivariable regression analysis, missing values were imputed 5 times using baseline characteristics as predictors. Separate analyses excluding patients with missing data were done as a sensitivity analysis.

Multivariable regression models for prediction of primary non-function and delayed graft function included donor type, category, sex, diabetes, recipient age, sex, kidney disease, dialysis time, panel reactive antibodies, HLA mismatch, cold ischemia time, and anastomosis time. Clinically relevant interactions of donor type $\mathrm{x}$ category and donor type $x$ cold ischemia time were added to these models and statistical significance was assessed by the change in -2 log likelihood. Assumptions of the regression models were checked by Cook's distance for influential cases, by DFbeta for outliers, by predictor $\mathrm{x}$ In(predictor) interaction for linearity of the logit, by tolerance and variance inflation factor for collinearity, and by inspection of Kaplan-Meier curves and addition of timedependent variables to the regression model for proportional hazards. A P-value of less than 0.05 was considered to indicate statistical significance. Statistical analyses were performed using SPSS (SPSS Inc. Chicago, IL, USA, version 24).

\section{Results}

\section{Patient characteristics}

The characteristics of the patients are described in Table 6.1. In a six year period, 2519 kidney transplants were included, of which 73 were donated after euthanasia, 1212 after brain death, and 1234 after circulatory death. When regarding the donors, 
creatinine levels and number of patients suffering from diabetes did not differ significantly between the three groups. Euthanasia donors were on average 53 years old, three years younger than donors after circulatory death $(p=0.04) .62 \%$ of the euthanasia donors were male, compared to $46 \%$ of the donors after brain death $(p=0.01)$.

The immunosuppressive treatment consisted of a calcineurin inhibitor, corticosteroids and/or an anti-metabolite, following induction therapy. Which drugs they received was decided by the hospital where they were transplanted and treated, according to locally adopted international guidelines.

\begin{tabular}{|c|c|c|c|c|c|}
\hline Characteristics & $\begin{array}{c}\text { Euthanasia } \\
\qquad(\mathrm{N}=73)\end{array}$ & $\begin{array}{c}\text { DBD } \\
(\mathrm{N}=1212)\end{array}$ & P-Value & $\begin{array}{c}D C D \\
(N=1234)\end{array}$ & P-Value \\
\hline \multicolumn{6}{|l|}{ Donor } \\
\hline Age (yrs) & $53(12)$ & $55(18)$ & 0.14 & $56(16)$ & 0.04 \\
\hline Sex (male) & $62 \%$ & $46 \%$ & 0.01 & $61 \%$ & 0.85 \\
\hline Cause of death & & & 0.03 & & 0.02 \\
\hline Trauma & $26 \%$ & $35 \%$ & & $21 \%$ & \\
\hline Vascular & $70 \%$ & $43 \%$ & & $48 \%$ & \\
\hline Other & $4 \%$ & $22 \%$ & & $31 \%$ & \\
\hline Creatinine $(\mu \mathrm{mol} / \mathrm{L})$ & $69(20)$ & $67(34)$ & 0.34 & $63(30)$ & 0.46 \\
\hline Hypertension & $21 \%$ & $34 \%$ & 0.02 & $25 \%$ & 0.44 \\
\hline Diabetes & $23 \%$ & $22 \%$ & 0.91 & $22 \%$ & 0.95 \\
\hline Expanded criteria donor & $23 \%$ & $42 \%$ & 0.002 & $43 \%$ & 0.001 \\
\hline \multicolumn{6}{|l|}{ Recipient } \\
\hline Age (yrs) & $57(16)$ & $57(20)$ & 0.63 & $60(18)$ & 0.11 \\
\hline Sex (male) & $62 \%$ & $60 \%$ & 0.77 & $63 \%$ & 0.84 \\
\hline Kidney disease & & & 0.40 & & 0.52 \\
\hline Vascular & $32 \%$ & $38 \%$ & & $36 \%$ & \\
\hline Other & $68 \%$ & $62 \%$ & & $64 \%$ & \\
\hline Dialysis type & & & 0.77 & & 0.17 \\
\hline Pre-emptive & $11 \%$ & $9 \%$ & & $5 \%$ & \\
\hline Hemodialysis & $68 \%$ & $72 \%$ & & $74 \%$ & \\
\hline Peritoneal dialysis & $21 \%$ & $20 \%$ & & $21 \%$ & \\
\hline Dialysis time (yrs) & $2.8(3.1)$ & $2.8(2.8)$ & 0.78 & $2.8(2.6)$ & 0.58 \\
\hline Panel-reactive antibodies & & & 0.18 & & 0.02 \\
\hline$\leq 5 \%$ & $83 \%$ & $88 \%$ & & $92 \%$ & \\
\hline $6-84 \%$ & $17 \%$ & $11 \%$ & & $8 \%$ & \\
\hline$\geq 85 \%$ & $0 \%$ & $1 \%$ & & $1 \%$ & \\
\hline \multicolumn{6}{|l|}{ Graft } \\
\hline HLA mismatch & $3(1)$ & $3(2)$ & 0.13 & $3(2)$ & 0.07 \\
\hline Warm ischemia time (min) & $15(5)$ & - & - & $15(6)$ & 0.31 \\
\hline Cold ischemia time (hours) & $12(8)$ & $15(9)$ & 0.001 & $13(6)$ & 0.02 \\
\hline Anastomosis time (min) & $28(14)$ & $30(15)$ & 0.28 & $31(16)$ & 0.16 \\
\hline
\end{tabular}

Table 6.1 Baseline characteristics (DBD: Donation after brain death, DCD: Donation after circulatory death, ECD: Extended Criteria Donors, HLA: Human Leukocyte Antigen) 
$21 \%$ of the euthanasia donors and $34 \%$ of donors after brain death suffered from hypertension $(p=0.02)$. The percentage of euthanasia donors who could be classified as expanded criteria donor was $23 \%$, significantly lower than $34 \%$ of donors after brain death $(p=0.002)$ and $25 \%$ of donors after circulatory death $(p=0.001)$.

There was no significant difference between recipient age, sex, kidney disease, dialysis type and the previous period of dialysis in the three groups. The percentage of panelreactive antibodies (PRA) was higher in the euthanasia group than in the donation after circulatory death group. Human leukocyte antigen (HLA) mismatch, warm ischemic time and anastomosis time did not differ significantly between groups. The cold ischemic time in the euthanasia group was on average twelve hours, considerably shorter than fifteen hours in the donation after brain death $(p=0.001)$ and thirteen hours in the donation after circulatory death $(p=0.02)$ group.

\section{Patient and graft survival}

The transplant outcomes in Table 6.2 demonstrate that immediate and delayed graft function of kidneys donated after euthanasia (respectively 70 and 24\%) did not differ significantly from kidneys donated after brain death (respectively 74 and 22\%, $p=0.56$ ), while it was significantly better compared to kidneys donated after circulatory death (respectively 44 and 50\%, p<0.001).

\begin{tabular}{lccccc}
\hline Variable & $\begin{array}{c}\text { Euthanasia } \\
(\mathrm{N}=73)\end{array}$ & $\begin{array}{c}\text { DBD } \\
(\mathrm{N}=1212)\end{array}$ & P-Value & $\begin{array}{c}\text { DCD } \\
(\mathrm{N}=1234)\end{array}$ & P-Value \\
\hline Initial graft function & & & 0.56 & & $<0.001$ \\
Immediate function & $70 \%$ & $74 \%$ & & $44 \%$ & \\
$\quad$ Delayed graft function & $24 \%$ & $22 \%$ & & $50 \%$ & \\
$\quad$ Primary non-function & $7 \%$ & $4 \%$ & & & \\
Kidney function & & & & $43(23)$ & 0.04 \\
eGFR at 3 months (mL/min) & $48(21)$ & $46(24)$ & 0.29 & $47(26)$ & 0.45 \\
eGFR at 1 year (mL/min) & $54(26)$ & $48(26)$ & 0.60 & $48(26)$ & 0.41 \\
eGFR at 2 years (mL/min) & $56(37)$ & $47(25)$ & 0.28 & $48(27)$ & 0.90 \\
eGFR at 3 years (mL/min) & $43(55)$ & $48(26)$ & 0.80 & $47(25)$ & 0.89 \\
eGFR at 4 years (mL/min) & $48(47)$ & $47(26)$ & 0.78 & $92 \%$ & 0.55 \\
Graft survival at 1 year & $93 \%$ & $92 \%$ & 0.60 & $94 \%$ & 0.42 \\
Recipient survival at 1 year & $95 \%$ & $95 \%$ & 0.60 & & $94 \%$ \\
\hline
\end{tabular}

Table 6.2 Transplantation outcome (eGFR: estimated Glomerular Filtration Rate, DBD: Donation after brain death, DCD: Donation after circulatory death) 


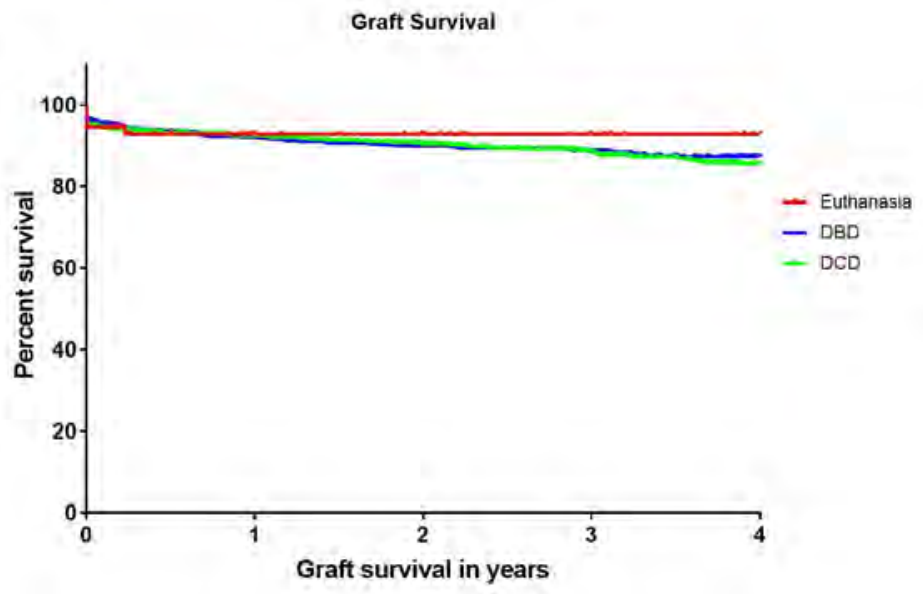

\begin{tabular}{|l|r|r|r|r|r|}
\hline Time in years & 0 & 1 & 2 & 3 & 4 \\
\hline Euthanasia & 73 & 35 & 25 & 15 & 7 \\
\hline DBD & 1212 & 865 & 646 & 440 & 247 \\
\hline DCD & 1234 & 866 & 659 & 432 & 253 \\
\hline
\end{tabular}

Figure 6.1A Graft survival in years of kidneys transplanted following donation after brain death (DBD), following donation after circulatory death (DCD), or following euthanasia (Euthanasia)

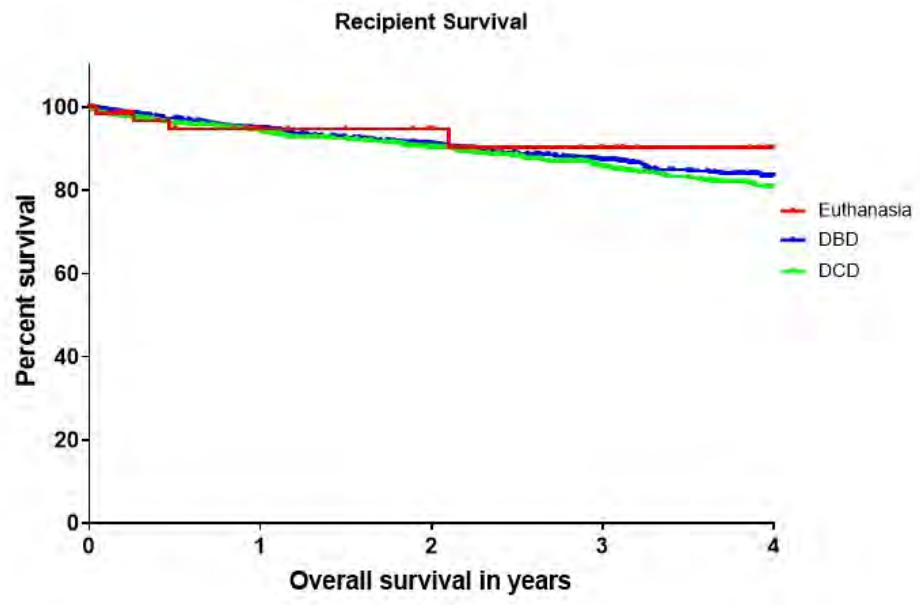

\begin{tabular}{|l|r|r|r|r|r|}
\hline Time in years & 0 & 1 & 2 & 3 & 4 \\
\hline Euthanasia & 73 & 35 & 25 & 15 & 8 \\
\hline DBD & 1212 & 882 & 661 & 446 & 250 \\
\hline DCD & 1234 & 887 & 673 & 440 & 259 \\
\hline
\end{tabular}

Figure 6.1B Recipient survival in years of patients who received a kidney from a donor after brain death (DBD), from a donor after circulatory death (DCD), or a donor following euthanasia (Euthanasia) 
The glomerular filtration rate at 3 months was $48 \mathrm{ml} / \mathrm{min}$ in kidneys donated after euthanasia, $46 \mathrm{ml} / \mathrm{min}$ in kidneys donated after brain death $(p=0.29)$, and $43 \mathrm{ml} / \mathrm{min}$ in kidneys donated after circulatory death $(p=0.04)$. This difference disappeared after one year. The Kaplan Meier curves (Figure 6.1A and 6.1B) show that graft and patient survival after one year were equivalent for all three groups: 93\% for kidneys donated after euthanasia, and $92 \%$ for kidneys donated after brain and circulatory death.

Multivariable regression analyses were done to adjust the associations of donor type with outcome measures for potential confounders (Table 6.3). Kidney transplantation using donors after euthanasia had similar clinical outcomes as kidney transplantation from donors after brain death. Kidneys from donors after euthanasia had 3.4 times less risk of delayed graft function as kidneys from donors after circulatory death. These findings are in line with the unadjusted comparisons presented in Table 6.2.

\begin{tabular}{|c|c|c|c|c|c|c|c|}
\hline & & & \multicolumn{5}{|c|}{ Donor Type } \\
\hline & & & Euthanasia & DBD & P-Value & $\mathrm{DCD}$ & P-Value \\
\hline \multirow[t]{3}{*}{$\begin{array}{l}\text { Odds ratio } \\
(95 \% \mathrm{Cl})\end{array}$} & \multirow[t]{2}{*}{$\begin{array}{l}\text { Primary non } \\
\text { function }\end{array}$} & SCD & REF & $\begin{array}{c}0.28 \\
(0.06-1.17)\end{array}$ & 0.08 & $\begin{array}{c}0.73 \\
(0.20-2.65)\end{array}$ & 0.63 \\
\hline & & ECD & REF & $\begin{array}{c}0.78 \\
(0.09-7.11)\end{array}$ & 0.82 & $\begin{array}{c}0.67 \\
(0.07-6.84)\end{array}$ & 0.72 \\
\hline & \multicolumn{2}{|c|}{ Delayed graft function } & REF & $\begin{array}{c}0.73 \\
(0.33-1.61)\end{array}$ & 0.42 & $\begin{array}{c}3.38 \\
(1.48-7.72)\end{array}$ & 0.006 \\
\hline \multirow[t]{2}{*}{$\begin{array}{l}\text { Hazard ratio } \\
(95 \% \mathrm{Cl})\end{array}$} & \multicolumn{2}{|l|}{ Graft survival } & REF & $\begin{array}{c}1.00 \\
(0.41-2.48)\end{array}$ & 0.99 & $\begin{array}{c}1.15 \\
(0.47-2.83)\end{array}$ & 0.76 \\
\hline & \multicolumn{2}{|c|}{ Recipient survival } & REF & $\begin{array}{c}1.12 \\
(0.41-3.07)\end{array}$ & 0.82 & $\begin{array}{c}1.29 \\
(0.47-3.51)\end{array}$ & 0.62 \\
\hline
\end{tabular}

Table 6.3 Multivariable logistic regression analysis for primary non-function and delayed graft function, and cox regression analysis for graft and recipient survival. In analyzing primary non-function, separate analyses were done for SCD and ECD donors, since the interaction between donor type and donor category was statistically significant. In the analysis of delayed graft function, anastomosis time was categorized since it violated the linearity of the logit assumption of the regression model. Graft survival was censored for recipient death with a functioning graft. Recipient age was added as a time-dependent covariate since it violated the proportional hazards assumption of the regression model.

The interaction of donor type with donor category was significant for the outcome of primary non-function. The regression analysis was therefore done separately for standard criteria and expanded criteria donors. The interaction of donor type with cold ischemia time was not significant for any of the outcomes. Sensitivity analysis removing cases with missing data showed similar results as the main analysis with multiple imputation of missing data. 


\section{Discussion}

This study is the first to report on the short- and midterm functioning of transplanted kidneys following euthanasia. Organ donation after euthanasia is currently performed in Belgium, The Netherlands and Canada. ${ }^{12}$ Euthanasia is also possible in Luxembourg and Colombia and it will be introduced this year in the State of Victoria (Australia). ${ }^{13}$ Physician assisted suicide, in which the physician prescribes lethal medication to the patient is allowed in a growing number of countries and states, including Switzerland and the States of Oregon, Vermont, Montana, Colorado and Washington).[8] Both procedures are increasingly seen as a valid option in end of life care. As a result, donation after euthanasia may increase, which necessitates knowledge about the outcome after transplantation.

Organ donation after euthanasia is performed in a hospital, and is similar to other donation after circulatory death procedures. ${ }^{11}$ It is essential that all due diligence requirements for euthanasia are fulfilled. The treating physician and an independent physician need to agree that the patient is suffering hopelessly and unbearably. After the euthanasia request has been granted the patient himself proposes to donate his organs. Following preparatory investigations to identify contraindications for donation, euthanasia is performed in a hospital. After respecting the legally mandated five minutes of circulatory arrest, the patient is declared dead and transported to the operating room, where his organs are procured. Directed donation is not possible, the donated organs are allocated through Eurotransplant. ${ }^{14}$

The vast majority of patients who undergo euthanasia are suffering from end stage malignancy, which makes them not suitable as a donor. 'Euthanasia donors' often suffer from neurodegenerative disorders which are not associated with deterioration of organ function of potentially transplantable organs. ${ }^{15}$ Donors after brain death suffer from a systemic inflammatory response with a negative impact on graft outcome. Donation after circulatory death category III donors, who die after withdrawal of life sustaining therapy, inevitably suffer from hypoxia, hypotension, and inadequate organ perfusion during the progression to circulatory arrest (agonal phase) and the mandatory 5-minute period of warm, pulseless ischemia. ${ }^{16}$ Therefore, organs from euthanasia donors, can be envisioned to be in a better condition than organs donated following brain or circulatory death. Euthanasia donors die rapidly after injection with a coma inducer and a muscle relaxant (the euthanasia drugs), resulting in a relatively short period of hypotension or hypoxia before the period of pulseless ischemia. 
This study confirms that the quality of kidneys for transplantation after euthanasia is equivalent to organs from other dead donors. Due to the short warm ischemia time compared to most traditional donors after circulatory arrest, the incidence of acute tubular necrosis is lower which translates into a lower incidence of delayed graft function in the euthanasia group. This difference does not persist after one year followup. This is in line with previous studies in which delayed graft function (DGF) was common after transplantation of kidneys from donors after circulatory death while this did not influence kidney function or graft survival. ${ }^{17-19}$

The information about the outcome of kidney transplantation from donors after euthanasia can be used in the discussion between patients and physicians if a patient who will undergo euthanasia asks to donate his organs. These results are also informative to policy makers, since they demonstrate that continuing these combined procedures is beneficial for the organ donor - whose last wish is fulfilled - as well as the recipients. The ethical debate on organ donation after euthanasia will be continued. Policy makers and ethicists are discussing whether the physician should inform a patient who is undergoing euthanasia about the possibility of organ donation, whether directed organ donation to a specific person should be possible, and even whether a patient can also be anesthetized before organ procurement, making heart donation possible.

In this study, the numbers of transplantations in the euthanasia group are too small and the follow-up period too short to draw firm conclusions about the long-term outcome of kidney transplantation after euthanasia. Future research should focus on obtaining short, medium and long term results in a larger cohort of patients. Even though the current results demonstrate that organ donation after euthanasia results in a good outcome for transplanted kidney, thereby supporting the feasibility of organ donation after euthanasia from a purely medical perspective, we are so far unaware of the long term results in liver, lung, or pancreas transplantation.

\section{Conclusion}

Kidney transplantation after euthanasia provides a valuable extension of the donor pool. Although the present number of donors after euthanasia is relatively small, this number is increasing because an increasing number of patients undergoing euthanasia wish donate their organs. The main reason for health care professionals to facilitate this procedure is the patient's autonomy. Giving life to others fulfils these patients' last wish. 


\section{References}

1. Purnell TS, Auguste P, Crews DC, Lamprea-Montealegre J, Olufade T, Greer R, Ephraim P, Sheu J, Kostecki D, Powe NR, Rabb H, Jaar B, Boulware LE. Comparison of life participation activities among adults treated by hemodialysis, peritoneal dialysis, and kidney transplantation: a systematic review. Am J Kidney Dis. 2013;62(5):953-73.

2. Wolfe RA, Ashby VB, Milford EL, Ojo AO, Ettenger RE, Agodoa LY, Held PJ, Port FK. Comparison of mortality in all patients on dialysis, patients on dialysis awaiting transplantation, and recipients of a first cadaveric transplant. N Engl J Med. 1999;341(23): 1725-30.

3. Suthanthiran M, Strom TB. Renal transplantation, N Engl J Med. 1994;331(6):365-76.

4. Tullius SG, Rabb H. Improving the supply and quality of deceased-donor organs for transplantation. N Engl J Med. 2018;378(20):1920-9.

5. Snoeijs MG, Schaubel DE, Hene R, Hoitsma AJ, Idu MM, Ijzermans JN, Ploeg RJ, Ringers J, Christiaans MH, W.A. Buurman WA, L.W. van Heurn LW. Kidneys from donors after cardiac death provide survival benefit. J Am Soc Nephrol. 2010;21(6);1015-21.

6. Bollen J, Ten Hoopen R, Ysebaert D, van Mook W, van Heurn E. Legal and ethical aspects of organ donation after euthanasia in Belgium and the Netherlands. J Med Ethics. 2016;42(8): 486-9.

7. Allard J, Fortin MC. Organ donation after medical assistance in dying or cessation of lifesustaining treatment requested by conscious patients: the Canadian context. J Med Ethics. 2017;43(9):601-5.

8. Emanuel EJ, Onwuteaka-Philipsen BD, Urwin JW, Cohen J. Attitudes and practices of euthanasia and physician-assisted suicide in the United States, Canada, and Europe. JAMA. 2016;316(1):79-90.

9. Bollen J, van Smaalen T, Ten Hoopen R, van Heurn E, Ysebaert D, van Mook W. Potential number of organ donors after euthanasia in Belgium. JAMA 2017;317(14):1476-7.

10. Kootstra G, van Heurn E. Non-heartbeating donation of kidneys for transplantation. Nat Clin Pract Nephrol 2007;3(3):154-63.

11. Kootstra G, Daemen JH, Oomen AP. Categories of non-heart-beating donors. Transplant Proc. 1995;27(5):2893-4.

12. Ball IM, Sibbald R, Truog RD. Voluntary euthanasia - implications for organ donation. N Engl J Med. 2018;379(10):909-11.

13. Smith P. State of Victoria will allow voluntary euthanasia from mid 2019. BMJ. 2017;359: j5571.

14. Bianchi A, Greenberg R. Deceased-directed donation: Considering the ethical permissibility in a multicultural setting. Bioethics 2019;33(2):230-7.

15. Bollen J, de Jongh W, Hagenaars J, van Dijk G, Ten Hoopen R, Ysebaert D, ljzermans J, van Heurn E, van Mook W. Organ donation after euthanasia: a Dutch practical manual. Am J Transplant. 2016;16(7):1967-72.

16. Morrissey PE, Monaco AP. Donation after circulatory death: current practices, ongoing challenges, and potential improvements. Transplantation. 2014;97(3):258-64.

17. Summers DM, Johnson RJ, Allen J, Fuggle SV, Collett D, Watson CJ, Bradley JA. Analysis of factors that affect outcome after transplantation of kidneys donated after cardiac death in the UK: a cohort study. Lancet. 2010;376(9749):1303-11.

18. Summers DM, Johnson RJ, Hudson A, Collett D, Watson CJ, Bradley JA. Effect of donor age and cold storage time on outcome in recipients of kidneys donated after circulatory death in the UK: a cohort study. Lancet. 2013;381(9868):727-34.

19. Wadei HM, Heckman MG, Rawal B, Taner CB, Farahat W, Nur L, Mai ML, Prendergast M, Gonwa TA. Comparison of kidney function between donation after cardiac death and donation after brain death kidney transplantation. Transplantation. 2013;96(3):274-81. 


\section{chapter}

\section{Organ donation}

\section{after euthanasia in children}

\section{Belgian and Dutch perspectives}

Jan Bollen, Rankie ten Hoopen, Mark van der Hoeven, David Shaw, Joe Brierley, Dirk Ysebaert, Ernst van Heurn, Walther van Mook Archives of Disease in Childhood 2019;104:827-830 



\section{Introduction}

Organ donation after euthanasia has been performed more than 70 times in Belgium and the Netherlands combined (personal communication, Jan Bollen, 2018). These two countries allow for euthanasia in minors as well, while Luxembourg, Colombia and Canada only allow adults to undergo euthanasia. A Dutch guideline on organ donation after euthanasia focuses on mentally competent adults, with a predominance of neurodegenerative diseases. ${ }^{1}$

The question arises whether organ donation after euthanasia should be possible in children and adolescents, and what are the legal, medical and ethical conditions for the combined procedure.

\section{Organ donation after euthanasia}

When all due diligence requirements for euthanasia have been fulfilled and no contraindications for organ donation are identified, it is possible for an adult to ask his physician to donate his organs as well. The patient undergoes several preparatory investigations to identify which organs are suitable for donation. Subsequently, euthanasia is performed by injection of a coma inducer and muscle relaxant. After 5 min 'no touch time' the organs are recovered in the operating room analogous to a donation after circulatory death (DCD) procedure. Lungs, liver, pancreas (islets) and kidneys can be donated and-if applicable-tissues as well. The preliminary transplantation results are promising, and organ donation after euthanasia is thus clearly of benefit to patients awaiting transplantation. ${ }^{2,3}$ Organ donation euthanasia in children and adolescents, where the patient is anaesthetised and his organs removed in a heart-beating procedure, ${ }^{4}$ is beyond the scope of this article.

In this article, the legal aspects of euthanasia and organ donation are elaborated, after which the medical and ethical dilemmas of the combined procedure are addressed, followed by a comprehensive discussion of these aspects in children and adolescents.

The authors argue neither in favour of nor against euthanasia and organ donation from children; we merely aim to increase awareness regarding the possibilities and limitations of organ donation after euthanasia in general, and in minors specifically. 


\section{Legal aspects of euthanasia in Belgium}

The Belgian Euthanasia Act enables mentally competent adults and emancipated minors to undergo euthanasia. ${ }^{5}$ An 'emancipated minor' is a person who legally obtained adulthood, for example, through a court ruling or marriage. A study among pediatricians demonstrated that 95 of the 121 (79\%) physicians thought that their professional duty sometimes includes the prevention of unnecessary suffering of children and adolescents by hastening death. ${ }^{6}$ Sixty-nine of 120 paediatricians (58\%) supported legalisation of life termination in some cases. ${ }^{7}$ In a survey among Belgian citizens, $86 \%$ felt that children who are suffering unbearably from an incurable disease should be allowed to undergo euthanasia even without approval of their parents. ${ }^{8}$

To qualify for euthanasia, a minor -defined as younger than 18 years- must be in a medically hopeless condition of constant and unbearable physical suffering that cannot be alleviated or cured, which will result in death within the foreseeable future, and which is the result of a serious incurable disorder caused by accident or physical illness. In addition, the patient's considered and repeated request should be voluntary and not the result of any external pressure. The treating physician has multiple conversations with the patient and judges whether he is mentally competent to make this difficult decision by himself (without any age requirement set in law). Another independent physician examines the patient and must ensure the suffering cannot be alleviated. A paediatric psychiatrist or psychologist needs to examine the patient, and the child's parents or guardians need to agree with the euthanasia request.

An adult who requests euthanasia does not need to be examined by a psychiatrist or psychologist unless he requests euthanasia because of psychiatric suffering, and he is able to request euthanasia when suffering from a chronic disease that will not cause death in the near future.

\section{Legal aspects of euthanasia in the Netherlands}

The Dutch Euthanasia Act allows children of 12 years or older to undergo euthanasia. ${ }^{9}$ Currently, the Dutch government is investigating the possibility of expanding this procedure to all ages, provided that the child is mentally competent. ${ }^{10}$

The Dutch due diligence requirements for euthanasia are the same for children (younger than 18 years of age) as for adults, which implies that any patient who wishes to 
undergo euthanasia should be hopelessly and unbearably suffering and well informed, while there is no other reasonable solution available. A second independent physician is consulted. The minor must be able to make a reasonable assessment of his interests in the matter. If the patient is 16 or 17 years of age, his parents (or legal guardian) should be involved in this decision. If the patient is between 12 and 16 years of age, his parents (or legal guardian) need to agree before a physician can perform euthanasia.

\section{Legal aspects of organ donation in Belgium}

The Belgian Organ Donation Act states that every inhabitant is a potential organ donor if that person has not clearly expressed otherwise. This makes Belgium an 'opt-out' jurisdiction. If that person is a mentally competent minor, he or his parents can, while he is alive, express the wish not to be an organ donor. If their child is not mentally competent, his parents or legal guardian can likewise refuse to consent to the child's organ donation. $^{11}$

\section{Legal aspects of organ donation in the Netherlands}

In the Netherlands, inhabitants currently must opt in to organ donation if they wish to become donors, though this will change within 2 years to an opt-out system. ${ }^{12}$ When a citizen is at least 12 years and is able to make a reasonable assessment of his interests in the matter, he is able to consent or refuse to be an organ donor. In children younger than 12 years of age, parents can decide on organ donation. ${ }^{13}$

\section{Medical aspects}

All children in Belgium and the Netherlands who underwent euthanasia so far were suffering from malignancy, which is nearly always a contraindication for organ donation. The Belgian Euthanasia Act contains the requisite that the minor's pathology will result in death in the near future. The legislator has thus focused on patients who are suffering from cancer. Organ donation after euthanasia is most commonly performed in adults suffering from a neurodegenerative disease. This type of disease resulting in death in the near future is very uncommon in minors. One exception is primary brain tumours without metastases. Imminent death is not a criterion in the Netherlands. 
When a patient requests organ donation after euthanasia, he often needs to undergo several preparatory investigations, such as blood tests and a medical imaging. The transplant surgeon determines which investigations would be necessary.

\section{Ethical aspects of organ donation after euthanasia in children and adolescents}

The laws on organ donation and euthanasia allow organ donation after euthanasia in minors. Various ethical issues need to be addressed. Multiple authors have stated that a minor cannot understand the implications of euthanasia. ${ }^{14}$ This is why the legislature considers it necessary that the parents agree with the procedure. It is, however, essential to engage and inform children and adolescents and let them form their own opinion within the limits of their comprehension. ${ }^{15,16}$ This is analogous to current medical and legal practice, where children can co-decide, together with their parents, on a medical treatment. ${ }^{17,18}$

As Belgian and Dutch legislators have reasoned, it would be even more unjust if children and adolescents would not have the possibility to undergo euthanasia and thus forced to suffer for a prolonged period of time, compared with the situation in which euthanasia would be performed.

The following four principles of biomedical ethics can be applied to help determine whether organ donation after euthanasia in children is ethical. ${ }^{19}$

\section{Respect for autonomy}

In a Dutch study among children aged 12 through 15 years, 75\% preferred to make their own choice about organ donation, whereas $13 \%$ wanted their parents to decide for them. Forty-three per cent had discussed organ donation more than once at home and $66 \%$ were willing to donate. ${ }^{20}$ Although not specifically designed to assess the children's level of understanding, the results suggest that children in this age group might have a basic understanding of organ donation and might have the capacity to make a rational choice based on arguments comparable to adult persons. In a context where children are permitted to access euthanasia, organ donation seems a minor decision by comparison. 
The legislators decided that children and adolescents are able to decide on organ donation as well as euthanasia.

The combination of these two decisions might seem too momentous for a child, but children can consent to donation if they are not considering euthanasia and can consent to euthanasia if they are not considering donation. Therefore, it would seem odd to deny the right to consent to both in tandem. Organ donation in this context is actually less ethically problematic in some respects as it involves a consent process where one can discuss the procedure with the patient, compared with a deceased donation consent process where others often have to make the decision.

\section{Non-maleficence}

Is the donor harmed by organ donation after euthanasia? Independently of the wish to donate, the donor requested death and sees this as a solution to his suffering. The possibility of donation cannot be the reason for euthanasia, which is why both decisions should be made independently of each other. Since the patient's relatives are not patients, the principle of non-maleficence does not apply to them directly. However, the donation procedure will impose limitations on the wishes of the bereaved parents. The time and setting of the euthanasia and donation should be well planned and discussed in depth to ensure as much comfort for the parents as possible.

\section{Beneficence}

Much benefit is achieved by the act of donation itself. The comforting thought that someone will be helped may give some meaning or importance to the child's death. ${ }^{21}$ For parents, the choice to support their child's organ donation can result in positive memories of what their child achieved, even after death. An additional point is that recipients of organs will also benefit from the donation, though this does not benefit the donor directly.

\section{Justice}

Does organ donation after euthanasia in children have any implications for equal access to care or distribution of resources? It would be unjust if access to organ donation was denied to children who request euthanasia. However, organ donation after euthanasia consumes considerable resources. Many physicians are involved while an operating room and a hospital bed need to be reserved for the donor and thus cannot be used by 
another patient. But it would be a mistake to assume that organ donation should be a low priority for beds or theatres. ${ }^{22}$

Careful consideration of the main ethical issues reveals that there are no major ethical obstacles to organ donation of children in the age group 12-16 years after euthanasia.

\section{Discussion}

The donor organ shortage affects all ages, including children. In 2017, 132 patients in the Netherlands and 91 patients in Belgium on the transplant waiting list died. In that same year, there were six deceased donors younger than 16 years in the Netherlands and 11 in Belgium. ${ }^{23}$ For correct interpretation of these numerical data, it should be acknowledged that children and adolescents do not necessarily receive organs from children and adolescents but can also receive organs from adults.

The debate surrounding euthanasia in minors is at an early stage. ${ }^{14}$ Until December 2017, only three minors underwent euthanasia in Belgium. ${ }^{24}$ In the Netherlands, the annual 2015 report mentions seven cases of euthanasia from 2002 to 2015, including five adolescents of 17 years, one of 16 years and one of 12 years. The annual 2016 report includes a case of a 16 year old. ${ }^{25}$ These minors were suffering from a malignancy, which makes it impossible for them to donate their organs. However, there are other pathologies that could cause a minor to request euthanasia, making them eligible for organ donation after euthanasia.

The issues of assisted dying for children and paediatric organ donation can carry negative connotations. The reality of a very young individual dying is hard to accept, but the same applies to cases of severely suffering children without quality of life.

Given the ongoing ethical discussions about euthanasia and organ donation in adults, the low incidence of euthanasia in children and adolescents and the fact that they will often not be medically eligible organ donors, one could argue that organ donation after euthanasia is not an option in children or adolescents. However, keeping in mind that respect for children's autonomy in Belgium and the Netherlands extends to enabling decision-making about deceased organ donation and decision-making about euthanasia, there does not appear to be any conclusive ethical argument against enabling decisionmaking on the combination of euthanasia and organ donation in children and adolescents-particularly given the strong safeguards for minors already in place for euthanasia. 
It is necessary and useful to clarify the key ethical objections to organ donation from children who have died following euthanasia, to avoid negative public perception. In a parallel discussion, The UK Donation Ethics Committee discussed objections to DCD heartdonation and determined that the mode of death was not relevant given the sustainable claim that death is an irreversible entity and that the diagnosis of death applies to that person as a whole, not to their individual organs. ${ }^{26}$ If death has occurred, any organ can be retrieved, irrespective of whether the deceased was a child or an adult and irrespective of whether the cause was euthanasia. Therefore, the key issue is not the mode of death, but the overall ethical and legal acceptability of euthanasia in minors, along with the timing of information provision about donation possibilities, which ought to be after the decision on euthanasia is made.

According to international conventions, children have the right to participate when decisions are made about them, to be treated equally and as individuals and to be allowed to influence decisions concerning them-proportionate to development/ability to do so. ${ }^{27,28}$

They also have the right to express their views freely in matters affecting them and have them afforded due weight commensurate with age and maturity. In fact, younger children with a chronic terminal disease can be involved in decision-making about endof-life care due to their experience of illness. ${ }^{29,30}$

Allowing organ donation after euthanasia in children and adolescents gives rise to the question whether a physician should always inform a patient who wants to undergo euthanasia about the possibility of organ donation. Once the decision to die has been made, it would appear to be paternalistic not to mention the also important possibility of making a decision about organ donation-particularly as not mentioning it could violate the child's autonomy and indirectly lead to suffering and deaths among potential recipients if donation does not go ahead.

Whether or not such a procedure should actually be performed should be the subject of societal debate. We note, however, that there are no categorical ethical objections to enabling this practice, and it is already permitted by law. 


\section{Conclusions}

Euthanasia is an accepted practice in Belgium and the Netherlands. Theoretically, organ donation after euthanasia in Belgium and the Netherlands is legally and medically possible for adults and children and adolescents and raises no categorical ethical objections.

Even though the few children who underwent euthanasia suffered from a malignancy, making organ donation impossible, organ donation after euthanasia in children and adolescents should be the subject of a scientific, legal, ethical and political debate, preparing policymakers and health professionals for a possible procedure in children who request euthanasia but do not have cancer. Questions to be addressed are whether organ donation after euthanasia ought to be mentioned to the patient or his relatives, and which preparatory investigations the child should undergo. 


\section{References}

1. Dutch Transplant Society. Dutch Guideline 'Organ donation after euthanasia' [Richtlijn Orgaandonatie na euthanasie]. 2017.

2. Van Raemdonck GMV D, Dupont L, Ysebaert D, et al. Initial experience with transplantation of lungs recovered from donors after euthanasia. Applied Cardiopulmonary Pathophysiology 2011;15:38-48.

3. Bollen J, van Smaalen T, Ten Hoopen R, et al. Potential number of organ donors after Euthanasia in Belgium. JAMA. 2017;317:1476-7.

4. Bollen JAM, Shaw D, de Wert G, et al. Euthanasia through living organ donation: ethical, legal and medical challenges. J Heart Lung Transplant. In Press. 2018.

5. [Wet betreffende de euthanasie]. Euthanasia Act (Belgium). 2002.

6. Dan B, Fonteyne C, de Cléty SC. Self-requested euthanasia for children in Belgium. Lancet. 2014;383:671-2.

7. Provoost V, Cools F, Mortier F, et al. Medical end-of-life decisions in neonates and infants in Flanders. Lancet. 2005;365:1315-20.

8. Temmerman M. In: Senate B, ed. Piece of legislation 5-1610/1: bill to change the law of May 28, 2002 on Euthanasia, considering minors, 2002.

9. Euthanasia Act (Netherlands). [Wet houdende toetsing van levensbeëindiging op verzoek en hulp bij zelfdoding]. 2001.

10. Smits J. Dutch government funds study to consider child euthanasia, life site. 2016. https://www.lifesitenews. com/ news/ dutch- government- funds- studyto-consider- childeuthanasia

11. Organ Donation Act (Belgium), Article 10 sub 1, June 13, 1986 [Wet betreffende het wegnemen en transplanteren van organen].

12. Lieber M. New Dutch law to make all adults organ donors unless they opt out, CNN. 2016 https:// edition. cnn. com/ 2018/02/ 14/ health/ new- dutch- law- organdonors-bn- intl/ index. html (accessed 14 Feb 2018).

13. Organ Donation Act (Netherlands). Wet op de orgaandonatie], Article 9.

14. Cuman G, Gastmans C. Minors and euthanasia: a systematic review of argument-based ethics literature. Eur J Pediatr. 2017;176:837-47.

15. Li AH, Rosenblum AM, Nevis IF, et al. Adolescent classroom education on knowledge and attitudes about deceased organ donation: a systematic review. Pediatr Transplant. 2013;17:119-28.

16. Siebelink MJ, Verhagen AAE, Roodbol PF, et al. Education on organ donation and transplantation in primary school; teachers' support and the first results of a teaching module. PLoS One. 2017;12:e0178128.

17. Derish MT, Heuvel KV. Mature minors should have the right to refuse life-sustaining medical treatment. J Law Med Ethics. 2000;28:109-24.

18. Stultiëns L, Goffin T, Borry P, et al. Minors and informed consent: a comparative approach. Eur J Health Law. 2007;14:21-46.

19. Sarnaik AA. Neonatal and pediatric organ donation: ethical perspectives and implications for policy. Front Pediatr. 2015;3:100. 
20. Siebelink MJ, Geerts EA, Albers MJ, et al. Children's opinions about organ donation: a first step to assent? Eur J Public Health. 2012;22:529-33.

21. Siebelink MJ, Albers MJ, Roodbol PF, et al. Children as donors: a national study to assess procurement of organs and tissues in pediatric intensive care units. Transpl Int. 2012;25:1268-74.

22. Shaw D, Gardiner D. Moral distance and distributive justice: how the increase in organ donation is helping us make better ethical decisions. Anaesthesia. 2015;70:10-13.

23. Eurotransplant. Statistics report library. 2017 http://statistics. eurotransplant. org/

24. Federal Monitoring and Evaluation Committee on Euthanasia, Eighth report to the legislative chambers, years 2016 and 2017. https:// overlegorganen. gezondheid. belgie. be/ sites/ default/ files/ documents/8_euthanasie- verslag_ 2016-2017- nl. pdf

25. Dutch Regional review committee on euthanasia, Annual Report 2016. https://www.euthanasiecommissie. nl/ binaries/ euthanasiecommissie/documenten/ jaarverslagen/ 2016/ april/ 12/ jaarverslag-2016/ RTEjv2016. pdf

26. Ethical issues in paediatric organ donation - a position paper by the UK Donation Ethics Committee (UKDEC). 2015.

27. Melton GB. Preserving the dignity of children around the world: the U.N. Convention on the rights of the child. Child Abuse Negl. 1991;15:343-50.

28. Council of Europe. Convention for the protection of human rights and dignity of the human being with regard to the application of biology and medicine: convention on human rights and biomedicine. Oviedo, 1997. CETS No. 164.

29. Bluebond-Langner M. The private worlds of dying children/Myra bluebond-langner. Princeton, N.J: Princeton University Press, 1978.

30. Kreicbergs $U$, Valdimarsdóttir $U$, Onelöv E, et al. Talking about death with children who have severe malignant disease. N Engl J Med. 2004;351:1175-86. 


\section{Abstract}

Euthanasia is categorically prohibited in almost all countries throughout the world. In Belgium and the Netherlands, combining euthanasia and subsequent organ donation in a so called 'donation after circulatory death' (DCD) - procedure is feasible on legal and medical grounds, and is increasingly gaining social and ethical acceptance. DCD heart donation however is currently not performed in Belgium and the Netherlands following euthanasia due to concerns surrounding the prolonged warm ischemia time associated with DCD and its effect upon subsequent heart function. A number of patients who undergo euthanasia explicitly express their wish to donate their organs in a 'living organ donation' procedure, causing them to die.

Assuming that euthanasia is permitted, as expressed in Dutch and Belgian legislation, this exploratory article investigates whether it could be legally and ethically sound to donate organs, especially the heart, as a living donor and perform euthanasia in the same procedure in a patient who fulfills the due diligence requirements for euthanasia. Organ donation euthanasia (ODE) would then cause death by the associated surgical procedure, and in addition would improve the quality of the other donated organs, a procedure that would fully respect the patient's autonomy. 


\section{Introduction}

A limited number of patients who undergo euthanasia wish to donate their organs. In this donation after circulatory death (DCD) procedure, it is currently possible to donate lungs, liver, kidneys and pancreas but not the heart due to concerns surrounding the prolonged warm ischemia time. ${ }^{1}$ Recent studies from the United Kingdom suggest that heart transplantation from DCD heart donation provides comparable short-term outcomes to traditional donation after brain death (DBD) heart transplants and can serve to increase heart transplant activity in well-selected patients. DCD heart donation is yet to be performed following euthanasia although research projects to explore DCD heart donation in general are currently being developed in Belgium and the Netherlands. ${ }^{2-5}$

In the experience of the authors, requests to be anesthetized and subsequently remove organs - including the heart - in a 'living organ donation' procedure, are voiced by an increasing number of patients. This type of procedure has been previously mentioned by Savulescu as 'organ donation euthanasia' (ODE), and would maximally respect the patient's autonomy, but may give others the impression that patients are killed for their organs. $^{6,7}$

In 2017, 6585 patients underwent euthanasia in the Netherlands, while in 2015, 2022 patients did so in Belgium. ${ }^{8,9}$ Although the majority of patients undergoing euthanasia suffer from malignancy, are too old or have other co-morbidities that preclude them from organ donation, previous research states that up to $10 \%$ of all patients who undergo euthanasia may be suitable organ donors. ${ }^{10}$ Typically these patients would be suffering from a neurodegenerative disease like multiple sclerosis or amyotrophic lateral sclerosis.

Not all of these medically suitable patients however wish to donate, nor do they want to undergo the preparatory investigations involved (including blood tests and medical imaging) or be admitted to the hospital for subsequent organ donation as euthanasia procedures are commonly performed at home or in a hospice. In Belgium, the euthanasia procedure is occasionally performed in the operating room. ${ }^{11}$

Current guidelines state that only the patient should pose the question of organ donation, and only after a positive response to the euthanasia question, thus keeping both procedures strictly separated. ${ }^{12}$ The authors however think a physician should always inform a patient who is medically suitable about the possibility of organ donation, 
even though this could disturb the trust relationship, as many patients may choose not to ask about donation because they assume it is not possible in this context. Consent of the patient's relatives for organ donation after euthanasia is not required.

Since 2005, at least 70 patients have donated their organs after euthanasia in Belgium and the Netherlands combined. ${ }^{13}$ This article explores whether it would be legally, medically and ethically possible to perform ODE. These aspects are addressed for Belgium and the Netherlands, since these countries introduced organ donation after euthanasia years ago, while Canada only initiated this possibility recently. ${ }^{14}$

\section{Legal considerations regarding euthanasia}

According to the Belgian and Dutch Laws on Euthanasia, a physician will not be punished if he performs euthanasia on a mentally competent person when euthanasia is requested voluntarily, well considered and repeatedly, and when this patient is in a medically hopeless condition of constant and unbearable physical or psychological suffering. When there is doubt about the patient's mental competence, or when it concerns psychiatric suffering, the patient is reviewed by a psychiatrist. Both laws do not mention how euthanasia should be performed, but a Dutch practical guideline of the Royal Dutch Medical Association explains this as using a coma inducer and muscle relaxant. $^{15-17}$

\section{Legal considerations regarding organ donation}

Since the proposed procedure does not involve patients who are brain dead, 'living donation' is the right term to use, even though this is normally used for people who donate their kidney, and do not die as a result of donation. The Dutch and Belgian laws on organ donation state that living donation is only possible in mentally competent people who are at least 18 years of age. ${ }^{18,19}$ Written consent of the patient is required.

When living donation could have serious consequences for the donor, or when it concerns organs that do not regenerate, this can only be carried out when the recipient is in a life-threatening situation. This however can be broadly interpreted. In the Netherlands, the law pertaining to living donation specifically focuses on donating one organ. In neither country does the relevant legislation provide a possibility to perform living donation which deliberately results in the death of the donor. 


\section{Ethical analysis}

Even in countries such as the Netherlands and Belgium, where organ donation after euthanasia is already legally possible and practiced, ODE faces several ethical objections. These will be outlined below.

First, ODE goes against the dead donor rule, which states that vital organs should be taken only from persons who are dead. ${ }^{20,21}$ This rule is a safeguard against abusive exploitation. One could argue that the dead donor rule becomes futile when a patient meets all criteria for euthanasia and consents to ODE, and thus makes use of his right of self-determination. The current procedure may be against the 'letter' of the dead donor rule, but not necessarily against its 'spirit'. In addition, it is questionable whether causing death in this context is a 'serious consequence' - as mentioned in the laws on living donation, given that euthanasia is requested. In fact, death is a desired consequence in this context. When a patient requests euthanasia, but is still so altruistic that he or she wants to donate organs, one could ask why it is necessary to prevent him from donating his heart? The physician can sedate the patient, after which relatives and family still have a moment to say goodbye. Enabling this possibility can make a patient's end of life more tolerable.

Second, living donation and euthanasia can both be seen as harming patients. Physicians have sworn to 'do no harm'. But this argument also applies to 'normal' organ donation after euthanasia. Living donation in combination with euthanasia does not harm the patient more than organ donation after euthanasia does, or euthanasia without organ donation for that matter. Making ODE possible, compared to neglecting the patient's wish and not facilitating this procedure, respects the Hippocratic Oath which mandates taking care of the organ donor and the recipient in the best possible way.

The third ethical objection to living donation and euthanasia is that people are instrumentalized in order to obtain organs; people could be pressured to undergo euthanasia in order to donate, while the public might think euthanasia was only granted to make organ donation possible. The topic of organ donation is therefore only to be discussed after a positive decision on euthanasia has been made.

The last, but not least important argument against organ donation euthanasia is that, even if all the preceding ethical objections were overcome, negative publicity and public fears about this type of organ donation could cause other people to refuse becoming an organ donor - which could reduce donation rates in the short term. The effects of 
negative media coverage could be dramatic, which could be prohibitive from a utilitarian point of view. ${ }^{22}$

Nevertheless, the fact remains that if all patients who ever underwent organ donation after euthanasia had donated their heart, more than 70 patients would be removed from the heart transplant waiting list. In 2017, 33 patients on that list in Belgium and the Netherlands died without receiving the organ they needed. ${ }^{23}$ It is impossible to know how many additional donor organs we realistically expect to achieve by allowing this procedure, but we know there are people who would choose this opportunity, and who would save a patient's life who is currently on the heart transplant wait list.

\section{Conclusion}

The right of self-determination of a patient who meets the due diligence requirements for euthanasia should ideally give this patient the possibility of also donating his heart, so that others can be helped and/or saved by as many donated organs as possible. Implementing organ donation euthanasia (ODE) into practice should however be cautiously approached, since public perception may not be ready for this combination of procedures yet.

Given the explorative character of this manuscript, the conclusions are provisional. The ethical objections might not be convincing, while the consequentialist and utilitarian arguments need further debate and analysis. Exploratory research evaluating public perspectives on this issue must thus be conducted, but maintaining public trust in organ donation is paramount. 


\section{References}

1. Bollen J, de Jongh W, Hagenaars J, et al. Organ Donation After Euthanasia: A Dutch Practical Manual. Am J Transplant. 2016;16(7):1967-72.

2. Messer SJ, Axell RG, Colah S, et al. Functional assessment and transplantation of the donor heart after circulatory death. J Heart Lung Transplant. 2016;35(12):1443-52.

3. Large S, Tsui S, Messer S. Clinical and ethical challenges in heart transplantation from donation after circulatory determined death donors. Curr Opin Organ Transplant. 2017; 22(3):251-9.

4. Messer S, Page A, Axell R, et al. Outcome after heart transplantation from donation after circulatory-determined death donors. J Heart Lung Transplant. 2017;36(12):1311-8.

5. Noterdaeme T, Detry O, Hans MF, et al. What is the potential increase in the heart graft pool by cardiac donation after circulatory death? Transpl Int. 2013;26(1):61-6.

6. Wilkinson D, Savulescu J. Should we allow organ donation euthanasia? Alternatives for maximizing the number and quality of organs for transplantation. Bioethics. 2012;26(1): $32-48$.

7. Lazaridis C, Blumenthal-Barby JS. Organ Donation Beyond Brain Death: Donors as Ends and Maximal Utility. Am J Bioethics. 2015;15(8):17-9.

8. Federal monitoring and evaluation committee on euthanasia, Seventh report to the legislative chambers, 2014-2015, August 09, $2016 \quad-\quad$ Accessible: https://overlegorganen.gezondheid.belgie.be/sites/default/files/documents/7_euthanasieverslag_2014-2015-nl_0.pdf.

9. Regionale toetsingscommissies euthanasie [Regional Review Committees on Euthanasia], Annual Report 2017-Accessible: https://www.euthanasiecommissie.nl/binaries/ euthanasiecommissie/ documenten/jaarverslagen/2017/mei/17/jaarverslag-2017/RTEjv2017.pdf.

10. Bollen J, van Smaalen T, Ten Hoopen R, van Heurn E, Ysebaert D, van Mook W. Potential Number of Organ Donors After Euthanasia in Belgium. JAMA. 2017;317(14):1476-7.

11. Ysebaert D, Van Beeumen G, De Greef K, et al. Organ procurement after euthanasia: Belgian experience. Transplant Proc. 2009;41(2):585-6.

12. Dutch Guideline 'Organ donation after euthanasia' [Richtlijn Orgaandonatie na euthanasie], november 2017, version 1.2, Dutch Transplant Society - Accessible: https://www.transplantatiestichting.nl/bestel-en-download/richtlijn-orgaandonatie-naeuthanasie.

13. Personal communication.

14. Allard J, Fortin MC. Organ donation after medical assistance in dying or cessation of lifesustaining treatment requested by conscious patients: the Canadian context. J Med Ethics. 2017;43(9):601-5

15. Bollen J, Ten Hoopen R, Ysebaert D, van Mook W, van Heurn E. Legal and ethical aspects of organ donation after euthanasia in Belgium and the Netherlands. J Med Ethics. 2016; 42(8):486-9.

16. Euthanasia Act (Belgium), May 28, 2002 [Wet betreffende de euthanasie].

17. Euthanasia Act (Netherlands), April 12, 2001, [Wet houdende toetsing van levensbeëindiging op verzoek en hulp bij zelfdoding]. 
18. Organ Donation Act (Belgium), Article 5, June 13, 1986 [Wet betreffende het wegnemen en transplanteren van organen]. In.

19. Organ Donation Act (Netherlands) [Wet op de orgaandonatie], Article 3. In.

20. Truog RD, Miller FG, Halpern SD. The dead-donor rule and the future of organ donation. $\mathrm{N}$ Engl J Med. 2013;369(14):1287-9.

21. Bernat JL. Life or death for the dead-donor rule? N Engl J Med. 2013;369(14):1289-91.

22. Volk ML, Lok AS, Ubel PA, Vijan S. Beyond utilitarianism: a method for analyzing competing ethical principles in a decision analysis of liver transplantation. Med Decis Making. 2008;28(5): 763-72.

23. Numbers found through the data on the Eurotransplant website http://statistics.eurotransplant.org/. 

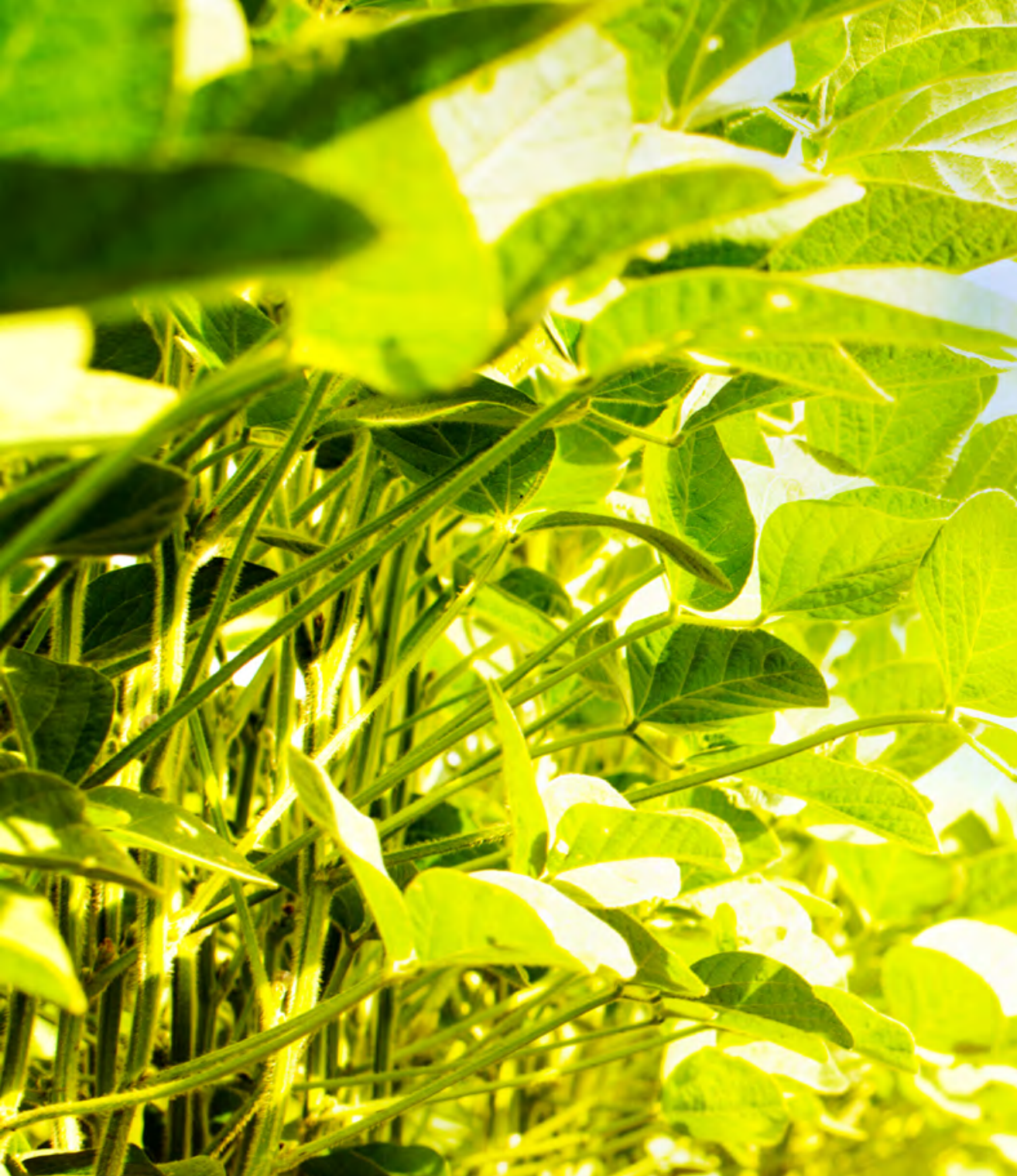

V

2

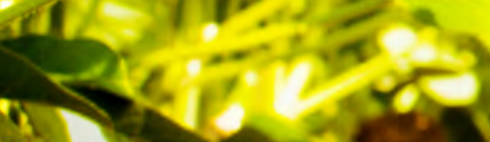

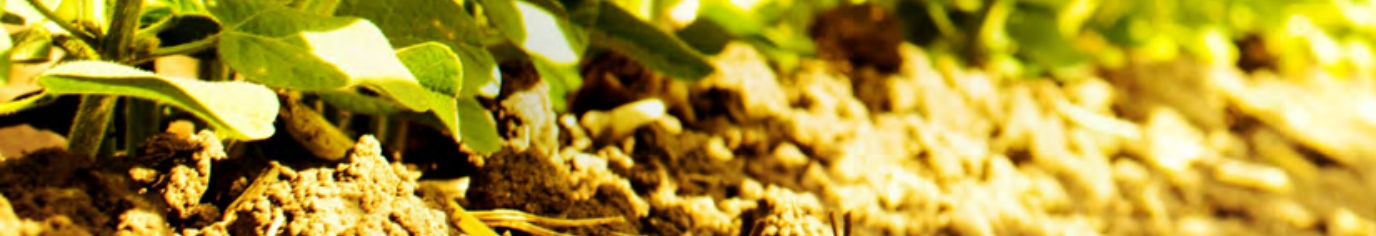

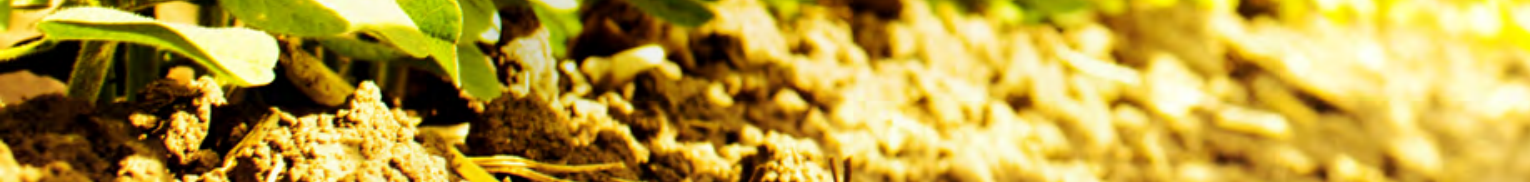

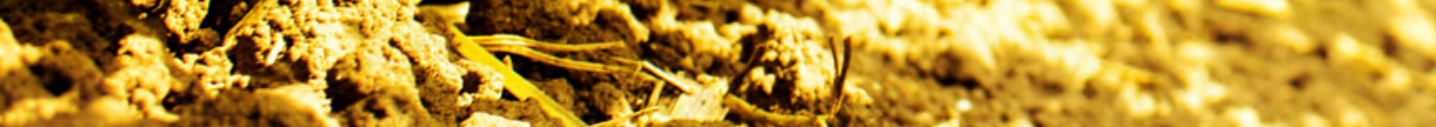

M. I.

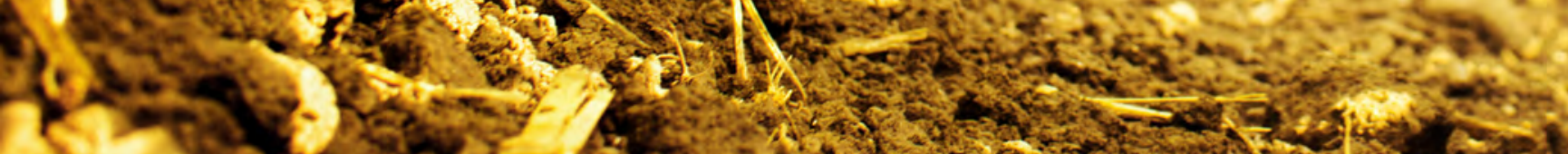

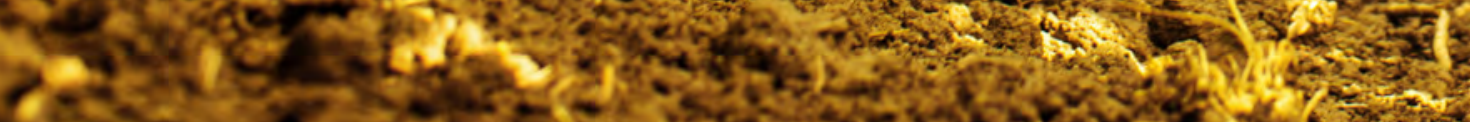

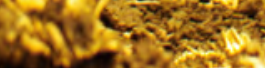



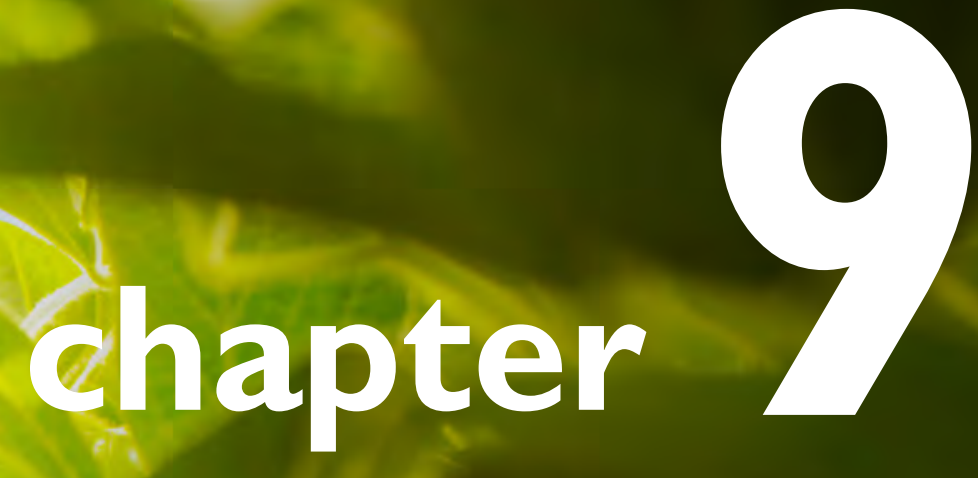

$2 \times$

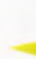

\section{General discussion}

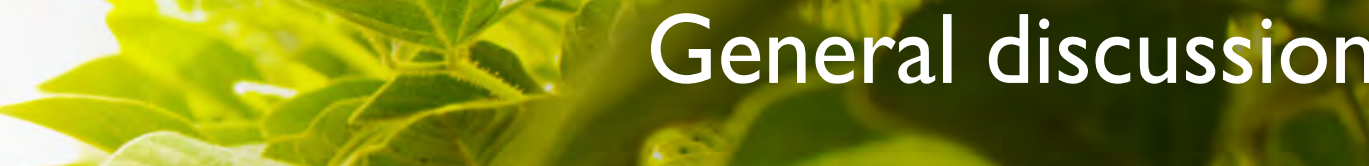

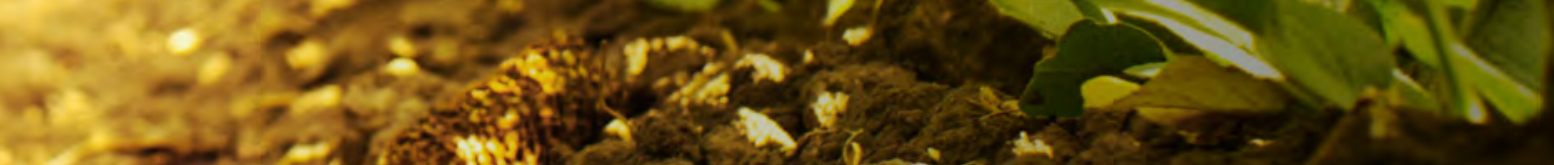

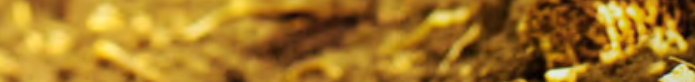

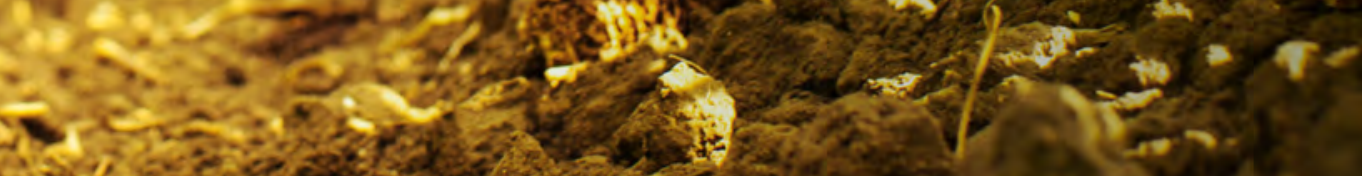

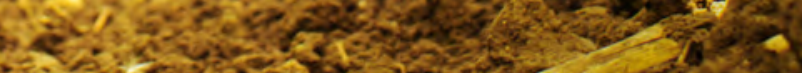

sitis: 



\section{General discussion}

Organ donation as well as euthanasia are each in itself part of an ongoing debate. The discussion on organ donation after euthanasia was still premature before this thesis was initiated, and still causes many (emotional) reactions. The authors of the chapters in this thesis do not strive for organ donation after euthanasia to become common practice, but merely want to inform the professionals as well as the general public about the existence, background, requirements and limitations associated with this procedure. It cannot be denied that the studies performed for this thesis have increased attention for organ donation after euthanasia. These studies therefore have been an important contributory factor in the societal and political debate.

In this chapter, the main results of the studies in this thesis are reviewed, in perspective of the available scientific literature, and it is discussed how these results contribute to answering the research questions formulated in Chapter 1 . The second part of this chapter elaborates on how the perception on organ donation after euthanasia has already evolved, and the future research that remains necessary.

\section{Lessons learned}

The following paragraphs contain the lessons learned from this thesis, together with questions that will still need to be discussed.

\subsection{Practical manual}

After discovering the possibility of organ donation after euthanasia, and acknowledging the fact that it had already been performed on an ad hoc basis, it was necessary to develop a practical manual for future procedures. Chapter 2 describes the consecutive elements that need to be addressed in an organ donation after euthanasia procedure. This step-by-step approach identifies the medical, legal and ethical challenges that are faced when performing organ donation after euthanasia.

From a medical perspective, one needs to identify the patient who might be eligible to donate after euthanasia, based upon their pathology and/or age. Next, the preparatory investigations necessary for organ donation are discussed. This contains a difficult balance between minimalizing the additional burden for the donating patient versus obtaining the information necessary for finding potential recipients for the organs. 
From a legal point of view, it is determined that the Euthanasia Act and Organ Donation Act do not interfere with the process of organ donation after euthanasia, even though they impose certain limitations. Ethical challenges identified concern the location where organ donation after euthanasia should be performed and whether the patient's requested moment to perform the procedure can always be respected. Other dilemmas are whether a physician should always inform a patient who will undergo euthanasia about the possibility of organ donation, and whether the transplant coordinator should meet the patient beforehand.

The practical manual has really improved the lives of patients. It was first used in the fifth Dutch patient who ever chose organ donation after euthanasia. In the next three years, more than twenty patients were able to donate their organs on the basis of that manual, and a plurality of patients were able to receive an organ. The practical manual however is based on a hypothetical case, written with the help of several transplant coordinators with a lot of experience in 'regular' organ donation.

One of the most striking questions of a patient demonstrates the practical challenges of organ donation after euthanasia compared to 'regular' donation after circulatory death: "Can I eat and drink on the day of the euthanasia procedure?". Patients are aware of the fact that they cannot eat or drink before surgery, while it would be ethically unacceptable to urge a patient not to consume anything on his last day on earth. Even though this requires some extra effort before the procurement, patients are not required to wear a hospital gown but can wear their own clothes.

Another difficult question only one hour before euthanasia would be performed was: "Are there any recipients found for my organs?". Recipients are sought and contacted when it is possible an organ will become 'available', when life sustaining therapy will be withdrawn or when a patient is declared braindead in the ICU. Patients are contacted as well when a patient who wants to donate organs will be euthanized in the next few hours. This is necessary to limit the ischemic time, but creates a moral dilemma. Informing the patient about the number of recipients that are found could put pressure on the patient who then will not dare to cancel the procedure. On the other hand, when it is clear that there is no match for any organ, one should perhaps inform the patient, so he still has the possibility to undergo euthanasia at home.

This practical manual has been the basis of the current Dutch guideline on organ donation after euthanasia, even though several differences between both documents remain. 


\subsection{Legal and ethical aspects in Belgium and the Netherlands}

The practical manual was created only after organ donation after euthanasia was already performed. This occurred for the first time in Belgium in 2005, and for the first time in the Netherlands in 2012. It is hard to explain why there are seven years in between, except for the fact that the Belgian cases were kept confidential for the first few years. There are some differences between the rules and regulations of both countries, which have been identified in Chapter 3 .

The differences between both countries give insight in what could improve the process. When performing post mortal organ donation in Belgium, three physicians need to sign a document declaring the donor has died, to avoid any distrust by the public. One would think that, as long as the 'dead donor rule' and five minute no touch time are respected, those signatures are superfluous.

Belgian law explicitly states that euthanasia is considered to be a natural death, while the Dutch legislator decided the opposite. This requires a municipal coroner and the public prosecutor to be involved in a organ donation after euthanasia procedure. Even though these people have always cooperated in the organ donation after euthanasia cases until now, making euthanasia a natural death could reduce the logistical challenges surrounding the process. However, this procedure was put in place as a safeguard, and to reassure the public that every euthanasia case would have enough 'checks and balances'.

Belgian physicians occasionally add heparin to the euthanasia drug to improve the quality of the donated organs, and occasionally perform euthanasia in the operating room, minimalizing the warm ischemic time and improving the quality of the organs before they can be removed. In the context of organ donation, health care professionals are allowed to take measures that do not contribute to the treatment of the patient, while these acts are not allowed to expedite death. Euthanasia will certainly cause death, because of which administering heparin does not imply additional harm to the patient. While this measure should also be discussed from an ethical point of view, it is necessary to research whether adding heparin improves the outcome of the donated organs. $^{1,2}$

\subsection{Liability}

In 2015, a patient in Nijmegen suffering from multiple system atrophy (MSA) requested a university hospital in the Netherlands to facilitate his wish to donate his organs after 
euthanasia. The hospital refused, since he was a patient at another hospital and there were still some medical questions and legal issues. It is not weird the hospital was a bit reluctant to quickly accept this request, eg. because of liability issues. Chapter 4 is an indepth investigation on the legal aspects of organ donation after euthanasia in the Netherlands.

If not all due diligence requirements would have been met in an organ donation after euthanasia procedure, the regional euthanasia review committee will forward the case to the health care inspection and the public prosecutor. The physician can then be held liable according to disciplinary law, according to criminal law, but also according to civil law.

Every medical act of a health care professional can be judged by disciplinary law. A disciplinary court can give a warning, a reprimand, or can even deprive someone of the authority to practice his health profession.

The public prosecutor can also decide to prosecute the physician, who could be punished with a prison sentence of a maximum of three years. Theoretically, all health care providers who were involved in the euthanasia procedure and the directors of the hospital may be seen an accomplice (article 51 paragraph 1 and 2 Penal code). They have been intentionally helpful in committing a crime, or they have deliberately provided the opportunity or means to do so (Article 48 of the Penal Code). It is not relevant whether the intentional acts were aimed at committing a crime.

The Supreme Court requires that there is a so-called 'double intention' and the intention is aimed at making a contribution to the offense. In the case of euthanasia followed by organ donation, both the hospital and the health care professionals contribute to the required actions that together can still be regarded as a criminal offense, although everyone relies on the correct assessment of the due diligence requirements by the performing physician. This trust is important since this physician is the only one who can make a correct assessment, based on the treatment relationship he has with the patient. The agreement between the hospital and the physician may state that the physician is sufficiently competent to assess the due diligence requirements.

A ruling of the disciplinary and/or criminal court can give rise to a civil litigation, based on the Dutch Civil Code. Chapter 7.5.5. deals with all aspects of a medical treatment agreement between a health care professional and a patient. One of its articles is about central liability: a hospital is responsible for every treatment that happens within its 
walls. However, since the legal literature states that euthanasia is not 'normal' medical practice, because its aim is not to 'heal' a patient, this chapter is not applicable to (organ donation after) euthanasia. Therefore, the central liability of general contract law has to be used when - from a legal perspective - one would consider the physician who performs euthanasia to be an assistant of the hospital, and thus extra contractually as its subordinate. On the basis of these rules, a patient's relatives can go to civil court to ask for compensation, which can also include affection damage.

In view of the possible legal implications, it is not surprising that hospitals have already set up committees that assess the euthanasia question of a patient, when combined with organ donation, a second time. As a result, organ donation after euthanasia requests have already been rejected. It is understandable that hospitals wish to protect themselves, but they seem to interfere with the doctor-patient relationship and the autonomous decision that the performing physician, advised by the second independent physician, takes in euthanasia. Moreover, one may wonder whether the hospital's assessment does not 'increase' the degree of responsibility in those cases where the procedure is nevertheless assessed as negligent by the regional review committee.

\subsection{Potential of organ donation after euthanasia}

Even though organ donation after euthanasia was already performed in Belgium and the Netherlands, it was unknown how many patients might be medically eligible to undergo organ donation after euthanasia. Therefore, the potential number of organ donors after euthanasia was identified in Chapter 5. Dutch euthanasia reports are to be kept confidential by law. Thanks to the Belgian Federal Monitoring and Evaluation Committee on Euthanasia it was possible to receive the anonymized euthanasia data from 2013 to 2015. These reports were compared with the contraindications for organ donation and its age requirements.

10,2 percent of all people who undergo euthanasia appear to be medically eligible for organ donation. In 2018, this would imply 240 people in Belgium. If extrapolated to the number of euthanasia cases in the Netherlands in 2017, 672 people might be medically eligible. However, an eligible donor needs to be willing to donate and to die in the hospital, but also needs to undergo preparatory investigations (e.g. medical imaging). Related to the total number of euthanasia cases, if only a small percentage of all these patients would donate, this could still have a significant impact on the transplant waiting lists. 
The question rises again whether people can make an autonomous decision - and thus 'informed consent' - if they are not aware of all their possibilities. In other words: should a physician who is confronted with a patient who will undergo euthanasia inform him about the possibility of organ donation (see 2.4) ?

Next to this ethical dilemma, organ donation might also have an impact on the health care system in a broad sense. If more patients would donate their organs after euthanasia, one would make more use of operating rooms, hospital beds, and medical imaging, but would also increase the workload of the performing physician, the transplant coordinator, the municipal coroner and other professionals involved. The financial consequences cannot be underestimated as well. On one hand, all organ donation costs are covered by (inter)national transplant services. On the other hand, the number of quality-adjusted life years (QALY's) rises when more patients on the transplant waiting list receive an organ, while these recipients do not need to be on dialysis anymore or do not need to be frequently admitted to the hospital. The latter will undoubtedly imply a net benefit for all parties. ${ }^{3}$

\subsection{Outcome of organ donation after euthanasia}

To ascertain that organ donation after euthanasia is a valuable procedure, it is necessary to ascertain that those transplanted organs are in good shape, and really improve the quality of life of the recipient for a sustainable period.

In chapter 6, the results of kidney transplants following organ donation after euthanasia are evaluated. All transplanted kidneys between 2012 and 2017 in the Netherlands were analyzed, to compare the results between kidneys transplanted after euthanasia, after donation after brain death, and after donation after circulatory death. The outcome parameters were (1) short term graft function, defined as immediate graft function, delayed graft function or primary non-function, (2) death censored graft survival, (3) glomerular filtration after 3 months, one and two years, and (4) recipient survival.

This research demonstrated that the function of kidneys transplanted following organ donation after euthanasia was comparable to the function of kidneys donated after brain death, and even better than those donated after circulatory death. Kidneys from donors after euthanasia had 3.4 times less risk of delayed graft function as kidneys from donors after circulatory death. While future research is necessary to analyze the function of other transplanted organs after euthanasia, and to evaluate the function of kidneys in a larger cohort and in the long term, these results confirm that organ 
donation after euthanasia benefits both parties: the donor who is able to fulfill his last wish by helping another with a function organ, and the recipient by receiving this organ.

If a physician would discuss the combined procedure with a patient, he can now refer to this research, in order to help the patient in deciding about donating his organs after euthanasia. This information will help policy makers and guideline authors as well. Further long term studies, as well as studies on the outcome of the other donated organs remain necessary.

\subsection{Minors}

When discussing the full potential impact of organ donation after euthanasia, one should also take into account the minors who undergo euthanasia. A question often asked at congresses is whether organ donation after euthanasia is also possible in children, since both Belgium and the Netherlands allow euthanasia for minors. In chapter 7, the issue of organ donation after euthanasia in children is studied from a legal perspective. In Belgium, patients of all ages - provided they are mentally competent can undergo euthanasia, but additional due diligence requirements apply. In the Netherlands, euthanasia is only possible in minors when they are at least twelve years old, even though the expansion of this age limit is subject of public debate. Canadians are discussing the possibility of medical assistance in dying in minors as well. ${ }^{4}$

In Belgium and the Netherlands, all minors who underwent euthanasia suffered from malignancy, which would have made it impossible for these patients to donate their organs. In addition, Belgian law requires that a minor who requests euthanasia is suffering from an illness which will cause the patient to die in the near future. This requirement does not exist in Dutch law. While organ donation after euthanasia in adults is mostly requested when suffering from a neurodegenerative disease, this does not cause imminent death in minors. A brain tumor without metastases could be an example of a pathology which could cause imminent death while one is still able to donate organs.

Discussing euthanasia in children is hard to accept. The combination with organ donation even seems a step too far. Nevertheless, identifying the four basic principles of biomedical ethics, no ethical obstacles against this combined procedure can be found: 1) Considering the respect for autonomy, organ donation seems less ethically problematic combined with euthanasia as it involves a consent process where one can discuss the procedure with the patient, compared with a deceased donation consent 
process where others often have to make the decision, 2) When discussing the principle of non-maleficence, one can state that the donor is not harmed by organ donation when it follows euthanasia 3) The principle of beneficence is obviously present, since the donor's last wish is respected and other patients will receive an organ, 4) The principle of justice states there should be equal access to care or distribution of resources, which is the case since it would be unjust if access to organ donation would be denied to children who request euthanasia.

Giving mentally competent minors the possibility to undergo organ donation after euthanasia thus fully respects their autonomy. Not allowing this combined procedure would be paradoxical, since they are allowed to undergo euthanasia and organ donation in itself.

The ethical threshold in children is thus higher than in organ donation after euthanasia in adults, but even after discussing the four basic principles of biomedical ethics, one needs to conclude that it would be unjust to deny a minor the possibility of organ donation after euthanasia - if this would be his true and last wish.

\subsection{Organ donation euthanasia (ODE)}

After determining the quality of transplantation after organ donation after euthanasia, it is useful to identify how the potential number of organ donors can be expanded and how the quality of the donated organs can be improved. In chapter 8 , the medical, legal and ethical aspects of 'organ donation euthanasia' (ODE) are discussed. Patients who donated organs after euthanasia requested whether it was possible to remove their organs while being anesthetized. The patient would then die because of removal of his organs, including his heart. The correct term would be 'living organ donation', since 'heart beating organ donation' (currently called donation after brain death (DBD)), requires the patient to be brain dead.

From a medical point of view, it is assumed that ODE would improve the quality of the organs, since there is no warm ischemic time. This would also make it possible to donate the heart, even though one is currently performing trials on heart donation after circulatory death with good preliminary results.

Since ODE would be defined as a form of living organ donation, Belgian and Dutch laws currently consider ODE to be illegal. Living organ donation from a legal perspective is only possible when the recipient's life is in danger, and when this does not have serious consequences for the donor. A living organ donation procedure that causes death is thus 
not allowed. The dead donor rule is developed to protect patients and states that organ donation of vital organs is only allowed when the patient is dead (including brain death). However, in the context of euthanasia, it is the patient's explicit request to die, because of which one could conclude the dead donor role does not apply here. Currently the general public will possibly be frightened by ODE, while it is necessary to avoid any negative publicity on organ donation. Perhaps in the future, lawmakers of both Belgium and the Netherlands might want to consider ODE when redrafting the laws on organ donation.

When considering the issue from an ethical perspective, it can be stated that ODE fully respects the patient's right of autonomy. One however should not forget the impact that ODE might have on the anesthesiologist and the surgeon who need to perform the procedure, and the moral distress and ethical dilemmas these and other health professionals are potentially facing.

If Belgium or the Netherlands would introduce DCD heart donation, those who donate after euthanasia seem to be the perfect group of patients to donate their heart, despite the circulatory arrest.

\section{Public debate and future research}

Organ donation after euthanasia was only introduced very recently, thus the debate about the procedure and its limitations and consequences is still ongoing. The first part of this chapter discussed the medical, legal and ethical challenges that are identified by this thesis. The combined procedure will still evolve in the future, depending on the political and public support. This is clearly demonstrated by the developments in Canada, where euthanasia was legalized during the drafting of this thesis (see 1.6.1.). Immediately after introducing medical assistance in dying (MAID), one also initiated a debate on organ donation after MAID.

An independent committee was mandated to issue recommendations on this issue by the provincial organisation responsible for examining ethics in science and technology, the Commission de l'éthique en science et en technologie (CEST). ${ }^{5}$ The ethics committee of Transplant Québec, the provincial OPO, issued recommendations as well. ${ }^{6}$ Both committees were in favour of donation after MAID. Comparable to the arguments in this thesis, Canadian author Kirby argues that donation after physician assisted death might even be less ethically problematic than DCD. Because of the possibility of, and 
requirement for, fully informed direct consent, donation after physician assisted death better respects and actualizes the autonomy interests of potential donors than does DCD. ${ }^{7}$

Contrary to the current policy in Belgium and the Netherlands, Allard and Fortin believe that it would be simple to add a note to the patient's file when the patient is listed stating his or her willingness to receive organs obtained after MAID. When allocating organs, the OPO would see this note and would not allocate organs obtained after MAID to a patient who does not wish to receive these organs. The recipient's choice and values would be respected. ${ }^{8}$ These authors agree that accepting organ donation after MAID is a way to respect the autonomy of patients, for whom organ donation is an important value.

In June 2019, the Canadian Medical Association published a guideline on deceased organ and tissue donation after medical assistance in dying and other conscious and competent donors. Comparable to the practical manual discussed in Chapter 2, their most important ethical concern is that he patient's request would be driven by a desire to donate organs. Therefore, they also require that organ donation will only be discussed after the decision or medical assistance in dying or withdrawal of life sustaining therapy is made. ${ }^{9,10}$

\subsection{Perception of organ donation after euthanasia}

A wise lesson for Canada would be to carefully discuss the topic of organ donation after euthanasia when it reaches a broad public. Even though the first experiences of organ donation after euthanasia led to good results for all parties, after every article that was published from this thesis, many people - including journalists and physicians - felt the urge to respond. Occasionally, the scientific proposals were taken out of context to demonstrate the atrocities that were going on in Belgium and the Netherlands. The authors of the articles in this thesis have however always stressed that organ donation after euthanasia is a very sensitive topic that should not be discussed lightly, but with great care. $^{11}$

In the Netherlands, the advantages of the procedure and the altruism of the patient who donated after euthanasia were often highlighted. In the 'Algemeen Dagblad', two daughters of a 61-year-old woman proudly testified about the courageous act of their mother who suffered from multiple sclerosis. They confirmed their mother was always available to help other people. The procedure was intense, but really fulfilled her last 
wish. Both daughters even tried to motivate other people to consider this procedure, and to at least register as an organ donor. ${ }^{12}$

After the practical manual of the Maastricht University Medical Center and the Erasmus Medical Center Rotterdam and subsequently the national guideline were published, national media commented on it in a positive way. ${ }^{13,14}$ In the Parliament, one hoped this would lead to more to more organ transplants. ${ }^{15}$ In other countries, journalists were often horrified by the idea of organ donation after euthanasia. In the United Kingdom, Member of Parliament (MP) Fiona Bruce told the Daily Mail: "The paper confirms the worst fears expressed by Parliament when the House of Commons conclusively voted to stop the legalisation of assisted suicide in this country. The possibility of euthanasia achieved through live organ donation, such as by removing a patient's beating heart, as posited in this paper is shocking and chilling". ${ }^{16}$ Lord Carlile of Berriew, a Liberal Democrat peer who is a leading lawyer, said: "I have extreme concerns about the ghoulish nature of the combined euthanasia and organ donation systems in the Netherlands and Belgium. Both can result in unbearable and irresistible pressure on an individual to die, and on a doctor to encourage death". ${ }^{17}$ Italian website Notizie Provita published an article titled 'Eutanasia, prelievo degli organi, consenso, omicidio', translated: Euthanasia, removal of organs, consent, murder. It mentions that one cannot help but notice that it goes well beyond normal euthanasia and organ donation (also from a Samaritan point of view), because intervening in the patient's death as a consequence of the withdrawal of the organs, the patient himself, consensually involved or not, is injured in his dignity as a person reduced and considered a mere deposit of spare parts to keep alive only for this purpose and only until each piece usable will have actually been used. ${ }^{18}$ In Canada, the journalists were a bit more neutral: "L'euthanasie pourrait stimuler le don d'organes, conclut une étude" (Euthanasia could stimulate organ donation, a study concludes). ${ }^{19}$

Organ donation is a topic surrounded with a negative image, since criticists do not hesitate to spread fake news about the procedure. This was painfully demonstrated during the recent legislative changes in the Netherlands towards an active donor registration system. It is thus necessary to be careful with spreading information about organ donation (after euthanasia), to avoid people withdrawing their choice.

\subsection{Consequences for medical professionals and the patient's relatives}

Organ donation after euthanasia is well received by the patients who request it and their relatives. However, we may not underestimate the substantial impact that euthanasia 
can have on these relatives or even on medical professional who performs the procedure. Even though health care professionals are not often confronted with euthanasia, it might have a major impact, resulting in tension and relief. Van Marwijk et al. discussed that relationship of a primary care physician with the patient, their loneliness, the role of the family, and pressure from society are the main issues that emerge. $^{20}$

In Belgium and the Netherlands, physicians are not legally obliged to cooperate in euthanasia when requested by their patient, they only have a moral obligation to refer the patient to a colleague. The practical manual and national guideline mentions that every medical professional has the possibility to refuse to cooperate in organ donation after euthanasia. While in 'regular' euthanasia practice a physician performs euthanasia at home, in a familiar environment, organ donation after euthanasia is performed in a hospital. Due to the nature of the procedure, other medical professionals are involved as well, such as (intensive care) nurses and physicians from the department where the patient is admitted. Even though these professionals often have been confronted with death before, one can be upset to meet a conscious patient who comes to the hospital to die and donate his organs.

Transplant coordinators are confronted with a change in their normal practice as well. While they are nearly always confronted with an unconscious patient in the intensive care unit, and they only need to discuss the procedure with the patient's relatives, they now have to communicate with the donating patient as well. This patient can have many (practical) questions, can be overwhelmed by grief, and will build a relationship of trust with the transplant coordinator quite quickly. Transplant coordinators are currently not trained to deal with these situations yet.

Relatives of the patient, and certainly those who will be present during the euthanasia procedure, will need to be informed extensively about the procedure. They will need to understand that, after the no touch period, the patient will be moved to the operating room as quickly as possible, in order to prevent too much warm ischemic time. Despite knowing that this was the patient's last wish, it adds an extra dimension to the grieving process. Transplant coordinators will discuss beforehand whether the relatives want to be informed when they are able to see the deceased patient again in the mortuary. It is eg. still possible to transport the patient home.

Research should be performed on how relatives and health care professionals think about an organ donation after euthanasia procedure afterwards. Physicians and nurses 
who do not want to cooperate in an organ donation after euthanasia procedure should not be forced, but their wish should be respected.

\subsection{How should patients be informed}

Before a patient can undergo organ donation after euthanasia, he first needs to be aware of this possibility. The very first scientific literature on organ donation after euthanasia from Ysebaert et al. already mentioned that, according to the Federal Control and Evaluation Committee Euthanasia in Belgium, the percentage of patients with debilitating neurologic disease with their request for euthanasia granted was between $5.0 \%$ and $9.5 \%$ of all euthanasia cases between 2003 and $2005 .{ }^{21}$ In Chapter 5, based on the Belgian euthanasia from 2013 through 2015, an estimated 10,2\% of patients who undergo euthanasia are possibly medically suitable to donate at least one organ.

It is very difficult to estimate how many patients will request and perform organ donation after euthanasia. They first need to be medically suitable, but they need to be willing to undergo preparatory investigations and to die in a hospital as well. This might be stressful for the patient but for his relatives as well.

It is assumed that better provision of information for the public might lead to an increase of organ donation after euthanasia. However, there is a thin line between informing and persuading patients. If a patient receives information about registering as a possible organ donor, he might think that he will never become an eligible donor. When a real decision needs to be made, the patient is often unconscious and his relatives need to make a choice. A conscious and well-informed patient who is about to undergo euthanasia will be very worrisome about the choice he should make. This consideration is applicable for the treating physician as well. The authors of the studies in this thesis believe that a physician should always inform a patient who is medically eligible for organ donation after euthanasia - and who fulfills all due diligence criteria for euthanasia - about the possibility of organ donation. The patient however might think that the physician only wants to perform euthanasia because the patient can donate organs, or he might feel pressured to consent. On the other hand, when a physician does not inform the patient - and thus not respect the patient's well-informed right of autonomy - the patient's relatives could appear to be dissatisfied. As well as in coercion in euthanasia, a patient could also state that he will only want to undergo euthanasia if the physician makes it possible for him to donate his organs. ${ }^{22}$ 
The compromise seems to be that all physicians need to be informed extensively about organ donation after euthanasia so they at least can help a patient who request organ donation after euthanasia himself. While writing this thesis, we were confronted with many anecdotes of patients and relatives whose physician told them that organ donation after euthanasia did not exist. When a physician is well informed, he can check the Donor Registry and he can rely on his own ability to assess the patient's possible reaction to inform him about the possibility of organ donation after euthanasia.

Even though the actual number of organ donation will never become 10,2\% of all euthanasia cases, every patient who donates after euthanasia equals at least one patient who can regain quality of life or whose life can be saved.

\subsection{Directed donation}

What if a well-informed patient decides to undergo organ donation after euthanasia and has a relative who is in urgent need of an organ? Someone who is on the transplant waiting list for a while and whose antigens are compatible with the patient who is about to donate after euthanasia? The United States have accepted the practice of 'directed donation' for years, and allow that an organ can be donated to a specific person after DCD. ${ }^{23,24}$ Belgium and the Netherlands however require that organs are allocated through Eurotransplant, depending on the priority and patient characteristics.

In the Dutch medical journal Medisch Contact, Kompanje proposed that patients with poor prognosis would donate one kidney before withdrawal of life sustaining therapy. ${ }^{25}$ All other organs could be procured after circulatory death. Many physicians reacted furious, and did not accept that a suffering patient would have to suffer from surgery not to the benefit of the patient himself - before dying. The same train of thought is applicable to patients who are about to undergo organ donation after euthanasia: if they would wish to donate to a specific person, it would be unacceptable that they would have to undergo surgery before being able to die and donate their other organs. Their disease would often even make it impossible to undergo anesthesia and surgery. Considering the principle of autonomy, a patient should be able to decide who will receive his organ. This idea is also supported in a utilitarian perspective where the right action is that which produces the greatest good for the greatest number of people. ${ }^{26}$ It would not differ from the procedure in living donation, and it would match the legal idea that organs are also someone's property (in this case the donor would be the owner). ${ }^{23}$

Directed donation was recently accepted in some regions: the United States (2009), Ontario (Canada) (2014) and the United Kingdom (2010). ${ }^{27-29}$ Therefore, it might be 
expected that European countries, including Belgium and the Netherlands, might adjust their policy, and thus allow directed donation in organ donation after euthanasia. Currently, research is being performed to expand the practice of directed donation in Canada.

It is needless to say that certain requirements will have to be applicable. In Ontario, it is required that: (a) appropriate consent is documented; (b) no other patients are in urgent clinical need of the organ; (c) the specific relative or close friend is currently on the waiting list; and (d) the organ is compatible for the intended recipient. ${ }^{23}$ These obligations could be applicable to directed organ donation after euthanasia as well. The guidelines in the United Kingdom even make a distinction between directed donation (a form of donation where a healthy person donates an organ to a specific, identified recipient with whom they have a genetic or preexisting emotional relationship), and directed altruistic donation (directed to a specific individual, without evidence of a qualifying genetic or pre-existing emotional relationship between the donor and recipient). The latter is eg. applicable to donation to a person who launched a request to receive an organ on social media. Whether that should be possible is beyond the scope of this discussion.

\subsection{Sedating the patient at home}

Occasionally, patients who requested to donate their organs after euthanasia have withdrawn after discovering they would have to die in a hospital. They requested whether it might be possible to be sedated at home before being transported to the hospital, where euthanasia could then be performed.

Of all 6585 Dutch euthanasia cases in 2017, 80,6\% of the patients died at home while only $2,6 \%$ of all cases were performed in a hospital. At home, there is no time pressure. The length of the dying process has no importance, while relatives can take all the time they want to stay with the deceased. In an organ donation after euthanasia procedure, this is not possible. It is totally understandable that the patient himself wants to die in a familiar environment, and is reluctant to die in a hospital.

From a medical perspective, there are risks for the procedure. Sedating and intubating always involves risks. When a patient would not have an empty stomach - which one cannot ask from the patient in this situation - there is a higher possibility of aspirating, causing hypoxia, influencing the quality of the lungs. This might lead to the lungs not being fit for donation anymore, and even death. ${ }^{30,31}$ From a legal point of view, one 
could argue that the patient's suffering disappears when he is sedated, comparable to a patient who becomes demented. It is however clear that the hopeless and unbearable suffering will be present again when the patient is not sedated anymore. From an ethical point of view, sedating the patient at home improves his right to autonomy, and it satisfies his last wish.

Contrary to what the practical manual and the current guideline describes, at least two Dutch patients have been sedated at home before organ donation after euthanasia in the hospital. In one case report, following oral administration of midazolam, the patient gradually fell asleep surrounded by family. ${ }^{32}$ After 50 minutes he became nonresponsive, which was the signal for the waiting anaesthesiologist to commence bagvalve-mask ventilation, administration of propofol and rocuronium intravenously and endotracheal intubation. Subsequent ambulance transfer under anaesthesia to hospital took 45 minutes. Two minutes after lethal injection at the hospital the patient's arterial pulse ceased, with confirmation of death five minutes later, followed by organ procurement. $^{33}$

The euthanasia review committee determined that all due diligence requirements in this procedure were fulfilled. ${ }^{34}$

Future research will have to determine the possibility of sedation at home before organ donation after euthanasia in the hospital is eligible from a medical, legal and ethical perspective.

\subsection{Using resources}

Transporting a sedated patient to the hospital is quite expensive. Chapter 6 discussed that the outcome of kidney transplantation after donation after euthanasia appears to be successful. This adds an argument to continuing the procedure of organ donation after euthanasia, even though this is an expensive procedure. In every euthanasia case, budget needs to be available for the performing physician, the independent physician who consults the patient, and the euthanasia drugs. When organ donation is involved, expenses are made for the admission of the patient in the hospital, medical professionals that are involved in the procedure and its administration, the operating room and the transplant team that needs to be present in the hospital to procure the organs. Since the patient intentionally comes to the hospital to be able to donate his organs, one needs to avoid any invoice for the relatives about the hospital stay or the hospital mortuary. 
In the case of the sedation at home before organ donation after euthanasia, expenses had to be made for the physicians sedating the patient, and the ambulance transporting the patient to the hospital. One can ask whether all these expenses weigh up against the benefits that one gains with an organ that is transplanted?

In 1998, American researchers made use of Dutch euthanasia numbers to calculate the cost savings from legalizing physician-assisted suicide. They stated that the medical expenditures increase exponentially as death approaches, so that the last month of life accounts for 30 to 40 percent of the medical care expenditures in the last year of life. Assuming that 2,7 percent of patients who die each year (62,000 Americans) would choose physician-assisted suicide, these patients would forgo an average of four weeks of life, and the medical costs in the last month of life for each patient who dies are $\$ 10,118$ (in 1995 dollars), they estimated that legalizing physician-assisted suicide and euthanasia would save approximately $\$ 627$ million in 1995 dollars. This amount was less than 0.07 percent of total U.S. health care expenditures. ${ }^{35}$

A Dutch study in 2014 identified that the costs of dialysis in the Netherlands is about 600 million euros each years. Every year on dialysis costs 80.000 euros, and a kidney transplant costs 80.000 euros as well. The average waiting time on the transplant waiting list is 3-5 years, and a transplanted kidney of a deceased donor often functions 10-15 years. Which would imply a cost reduction of 15.000 euros each year, as well as an additional life expectancy and increased quality of life. ${ }^{36}$

Canadian researchers used published data from the Netherlands and Belgium in 2017. They argued that medical assistance in dying could reduce annual health care spending across Canada by between $\$ 34.7$ million and $\$ 138.8$ million, exceeding the $\$ 1.5-\$ 14.8$ million in direct costs associated with its implementation. ${ }^{37}$ An American study from 2004 discusses the financial benefits of organ donation. They take into account the patient survival after transplant of heart, kidneys and liver, and come to the conclusion that one donor generates 13 QALYS. Based on other studies, they state that the cost of one QALY might be $\$ 100.000$. The medical costs of a donation procedure are $\$ 214.000$. Their conclusion is that one should be willing to spend up to $\$ 1,086,000$ (\$1.3 million $\$ 214,000$ ) to obtain one more donor, while one year of dialysis costs $\$ 63,700$ (in 1998). ${ }^{38}$ 


\section{Conclusion}

Organ donation after euthanasia is an incredibly interesting procedure with many medical, legal and ethical implications. Numerous stakeholders need to cooperate to make this combined procedure possible. By the end of 2018, in at least 50 Dutch cases of organ donation after euthanasia, general practitioners, transplant coordinators, municipal coroners, public prosecutors, transplant surgeons, intensivists, but most importantly: also patients and their relatives have done their utmost to be able to donate organs after euthanasia. This thesis has identified current medical, legal and ethical strengths and challenges, and has elaborated on possible future developments to improve the process of organ donation after euthanasia. These efforts will potentially lead to more patients being able to donate their organs after euthanasia, and more patients on the transplant waiting list receiving an organ. 


\section{References}

1. Motta ED. The ethics of heparin administration to the potential non-heart-beating organ donor. J Prof Nurs 2005;21(2):97-102.

2. Keshava HB, Farver CF, Brown CR, Shafii AE, Murthy SC, Yun JJ, Vakil N, Pettersson GB, Mason DP. Timing of heparin and thrombus formation in donor lungs after cardiac death. Thorac Cardiovasc Surg 2013;61(3):246-50.

3. Axelrod DA, Schnitzler MA, Xiao H, Irish W, Tuttle-Newhall E, Chang SH, Kasiske BL, Alhamad $\mathrm{T}$, Lentine KL. An economic assessment of contemporary kidney transplant practice. Am J Transplant 2018;18(5):1168-76.

4. Davies D. Medical assistance in dying: A paediatric perspective. Paediatr Child Health 2018;23(2):125-30.

5 Commission de l'éthique en science et en technologie. Enjeux éthiques liés au don d'organes en contexte d'aide médicale à mourir. Quebec, Quebec. 2016.

6. Comité d'éthique de Transplant Québec. Avis sur le don d'organes chez un patient qui demande une aide médicale à mourir, Transplant Québec, Montreal, Quebec. 2016.

7. Kirby J. Organ donation after assisted death: Is it more or less ethically-problematic than donation after circulatory death? Med Health Care Philos 2016;19(4):629-35.

8. Allard J, Fortin MC. Organ donation after medical assistance in dying or cessation of lifesustaining treatment requested by conscious patients: the Canadian context, J Med Ethics 2017;43(9):601-5.

9. Downar J, Shemie SD, Gillrie C, et al. Deceased organ and tissue donation after medical assistance in dying and other conscious and competent donors: guidance for policy. Canadian Medical Association Journal. 2019;191(22):E604-E613.

10. Organ donation after medical assistance in dying offers possibilities, CBC News, 03 June 2019, Accessible: https://www.cbc.ca/radio/whitecoat/organ-donation-after-medicalassistance-in-dying-offers-possibilities-1.5156392.

11. Abdo WF. Organ donation after euthanasia. Handle with great care. Ned Tijdschr Geneeskd 2014l;158:A8617.

12. Blommers C. Zelf sterven en vijf mensen het leven redden - https://www.ad.nl/gezond/zelfsterven-en-vijf-mensen-het-leven-redden a21b1c53/, Algemeen Dagblad, October 18, 2014.

13. B.d. Vries, Orgaandonatie na euthanasie makkelijker, NOS, https://nos.nl/artikel/2005061orgaandonatie-na-euthanasie-makkelijker.html, 22 November 2014.

14. J. Visser, Euthanasie en donatie kunnen samengaan, Medisch Contact, https://www.medischcontact.nl/nieuws/laatste-nieuws/artikel/euthanasie-en-donatiekunnen-samengaan.htm, 25 November 2014.

15. VVD hoopt op meer orgaandonatie na euthanasie, NU.nl, https://www.nu.nl/gezondheid/ 3937714/vvd-hoopt-meer-orgaandonatie-euthanasie.html, 25 November 2014.

16. Steve Doughty, 'Remove organs from euthanasia patients while they're still ALIVE': Medical researcher's grisly proposal to improve the chances of successful transplants, Daily Mail, 31 March 2016 - Accessible: http://www.dailymail.co.uk/news/article-3516565/Remove-organseuthanasia-patients-ALIVE-Medical-researcher-s-grisly-proposal-improve-chances-successfultransplants.html. 
17. Michael Cook, Everybody's a winner when euthanasia combines with organ donation, say doctors, BioEdge, April 2, 2016 - Accessible: https://www.bioedge.org/bioethics/everybodysa-winner-when-euthanasia-combines-with-organ-donation-say-d1/11814.

18. Aldo Vitale, Eutanasia, prelievo degli organi, consenso, omicidio, Notizie Provia, 6 April 2016 Accessible: https://www.notizieprovita.it/notizie-dal-mondo/eutanasia-prelievo-degli-organiconsenso-omicidio/.

19. Mathieu Perreault, L'euthanasie pourrait stimuler le don d'organes, conclut une étude, La Presse, 1 May 2017 - Accessible: http://plus.lapresse.ca/screens/f240d357-0e59-43fa-a34f97bf81e0c042_7C_3bmVpmisrUmn.html.

20. van Marwijk H, Haverkate I, van Royen $\mathrm{P}$, The AM. Impact of euthanasia on primary care physicians in the Netherlands, Palliat Med 2007;21(7): 609-14.

21. Ysebaert D, Van Beeumen G, De Greef K, Squifflet JP, Detry O, De Roover A, Delbouille MH, Van Donink W, Roeyen G, Chapelle T, Bosmans JL, Van Raemdonck D, Faymonville ME, Laureys S, Lamy M, Cras P. Organ procurement after euthanasia: Belgian experience, Transplant Proc 2009;41(2):585-6.

22. Hicks MHR. Physician-assisted suicide: a review of the literature concerning practical and clinical implications for UK doctors. BMC Fam Pract 2006;7:39.

23. A. Bianchi, R. Greenberg, Deceased-directed donation: Considering the ethical permissibility in a multicultural setting, Bioethics (2018).

24. Cronin AJ, Price D. Directed organ donation: is the donor the owner? Clin Ethics 2008;3(3): 127-31.

25. Y.d.G. E. Kompanje, Nierdonatie kan eerder (Kidney donation can be done earlier), Medisch Contact (https://www.medischcontact.nl/nieuws/laatste-nieuws/artikel/nierdonatie-kaneerder.htm) (02 March 2010).

26. Driver, J. (2014, September 22). The history of utilitarianism. The Stanford Encyclopedia of Philosophy, available: https://plato.stanford.edu/archives/win2014/entries/ consequentialism/.

27. Revised Uniform Antatomical Gift Act (2006), last revised or amended in 2009, drafted by the National Conference of Commissioners on Uniform State Laws, available: https://www.uniformlaws.org/HigherLogic/System/DownloadDocumentFile.ashx?Document FileKey=6705441e-40b7-fbd4-edd5-5748c63fbd79\&forceDialog=0.

28. Ross, K. (2011). Directed organ donations from deceased donors: Describing and assessing the views of transplant professionals in Ontario. Germany: LAP Lambert Academic, available: https://tspace.library.utoronto.ca/bitstream/1807/24630/1/Ross_Kelley_A_201003_MSc_th esis.pdf.

29. Human Tissue Authority, Guidance to Transplant Teams and Independent Assessors, March 2015, available: https://www.hta.gov.uk/sites/default/files/Guidance_to_Transplant_Teams_ and_Independent_Assessors\%20(1)_0.pdf.

30. Sousa AS, Ferrito C, Paiva JA. Intubation-associated pneumonia: An integrative review, Intensive Crit Care Nurs 2018;44:45-52.

31. Fouche PF, Stein C, Simpson P, Carlson JN, Doi SA. Nonphysician out-of-hospital rapid sequence intubation success and adverse events: A systematic review and meta-analysis, Ann Emerg Med 2017;70(4):449-59.e20. 
32. Dutch Guideline 'Organ donation after euthanasia' [Richtlijn Orgaandonatie na euthanasie], november 2017, version 1.2, Dutch Transplant Society - Accessible: https://www.transplantatiestichting.nl/bestel-en-download/richtlijn-orgaandonatie-naeuthanasie.

33. Mulder J, Sonneveld JPC. Organ donation following euthanasia starting at home, Transpl Int 2017;30(10):1075-6.

34. Regionale toetsingscommissies euthanasie [Regional Review Committees on Euthanasia], Annual Report 2017, Case 2017-86, p. 31 - Accessible:

https://www.euthanasiecommissie.nl/binaries/euthanasiecommissie/documenten/jaarversla gen/2017/mei/17/jaarverslag-2017/RTEjv2017.pdf and https://www.euthanasiecommissie.nl/binaries/euthanasiecommissie/documenten/publicatie s/oordelen/2017/medisch-zorgvuldige-uitvoering/oordeel-2017-86/Oordeel+2017-86.pdf.

35. Emanuel EJ, Battin MP. What are the potential cost savings from legalizing physician-assisted suicide? N Engl J Med 1998;339(3):167-72.

36. M Hommes, B Haase, A Hoitsma, Kosten en baten van transplantatie, Kennislink - Stichting Biowetenschappen en Maatschappij, 25 September 2014 - accessible: https://www.nemokennislink.nl/publicaties/kosten-en-baten-van-transplantatie/.

37. Trachtenberg AJ, Manns B. Cost analysis of medical assistance in dying in Canada, CMAJ 2017;189(3):E101-5.

38. Mendeloff J, Ko K, Roberts MS, Byrne M, Dew MA. Procuring organ donors as a health investment: how much should we be willing to spend? Transplantation 2004;78(12):1704-10. 

Samenvatting 


\section{Samenvatting}

Dit proefschrift behandelt de medische, juridische en ethische aspecten van orgaandonatie na euthanasie, een procedure die het mogelijk maakt dat iemand euthanasie ondergaat en vervolgens zijn organen doneert.

\section{Orgaandonatie, en euthanasie}

De wetgeving inzake orgaandonatie maakt zowel in Nederland als België een onderscheid tussen het ter beschikking stellen van organen bij leven en het ter beschikking stellen van organen na overlijden. De eerste situatie doet zich voor wanneer iemand bijvoorbeeld (bij leven) zijn nier doneert aan een ander. Wanneer we het hebben over orgaandonatie na overlijden wordt er gesproken van donatie na hersendood (donation after brain death, DBD), en van donatie na circulatoir arrest (donation after circulatory death, DCD) nadat hartstilstand is ingetreden. Er bestaan volgens de medische literatuur vier categorieën DCD, die ook wel de 'Maastricht classificaties' genoemd worden. Orgaandonatie na euthanasie wordt in deze context beschreven als een 'type 3', vergelijkbaar met de situatie waarin de behandeling van een patiënt die is opgenomen op de intensive care afdeling wordt gestaakt. Na het stopzetten van de levensondersteunende maatregelen kan orgaandonatie plaatsvinden indien de patiënt binnen twee uur overlijdt. In recente literatuur wordt ook wel gesproken van 'type $\mathrm{V}$ ' wanneer het over orgaandonatie na euthanasie gaat.

In Nederland dient men zich momenteel nog te registreren als orgaandonor, ook wel een opt-in systeem genoemd. Vanaf de zomer van 2020 zal men geregistreerd staan in het Donorregister als 'geen bezwaar', tenzij men één van de vier andere keuzes heeft gemaakt en geregistreerd (ik wil donor zijn, ik wil geen donor zijn, ik wil dat mijn nabestaanden beslissen, of ik wil dat een specifiek persoon beslist). In België wordt er sinds 1986 een opt-out systeem gehanteerd, waarbij iedereen als orgaandonor wordt beschouwd, tenzij men hiertegen een verzet heeft geuit of geregistreerd.

De patiënt die euthanasie wenst te ondergaan dient te voldoen aan de wettelijke zorgvuldigheidseisen. Zowel in België als in Nederland werd euthanasie in 2002 gelegaliseerd. Er dient sprake te zijn van uitzichtloos en ondraaglijk lijden, het moet gaan om een weloverwogen en vrijwillig verzoek van de uitvoerig geïnformeerde patiënt, er dienen geen redelijke andere opties meer beschikbaar te zijn, en er dient een tweede, onafhankelijk arts de patiënt te beoordelen. 
Nadat de procedure werd uitgevoerd door de uitvoerend arts beoordeelt een commissie of dit zorgvuldig is gebeurd. In Nederland wordt dit besluit genomen door de regionale toetsingscommissies euthanasie, en in België door de federale controle- en evaluatiecommissie euthanasie.

In 2018 ondergingen in Nederland 6126 patiënten euthanasie, in België waren er 2357 euthanasiegevallen.

\section{De geschiedenis van orgaandonatie na euthanasie in het kort}

In 2005 was er voor het eerst een patiënte in België die voldeed aan de zorgvuldigheidseisen voor euthanasie, en vervolgens aan haar arts voorstelde om ook haar organen te doneren. De huisarts nam contact op met professor Ysebaert, transplantatiechirurg aan het Universitair Ziekenhuis van Antwerpen, en een week later kon deze patiënte haar organen doneren onmiddellijk nadat de euthanasie werd uitgevoerd. De eerste jaren werd deze procedure nog enkele keren uitgevoerd, maar kwam het niet tot publicatie in de wetenschappelijke, of populaire media. Het duurde nog tot 2012 vooraleer dezelfde procedure werd uitgevoerd in Nederland.

Nadat de eerste procedures van orgaandonatie na euthanasie in de media waren gebracht, kwamen zorgaanbieders en -verleners voor de vraag te staan of deze gecombineerde procedure wel toelaatbaar is. Aanvankelijk was de reactie in de praktijk terughoudend. Onbekendheid met de procedure bracht onzekerheid mee over de implicaties ervan, zowel medisch-technisch als in ethische en juridische zin. Het heeft decennia geduurd vooraleer euthanasie en orgaandonatie apart aanvaard werden, maar het heeft relatief kort geduurd voordat de combinatie euthanasie-orgaandonatie haar weg vond naar de medische praktijk. Het bleek niet nodig om de wetgeving aan te passen. Ook zal een rol hebben gespeeld dat euthanasie en orgaandonatie in Nederland geen nieuwe rechtsfiguren meer waren; alleen de combinatie van beide bracht een verandering met zich mee.

Dit proefschrift heeft als doel de huidige praktijk inzake orgaandonatie na euthanasie in kaart te brengen, de uitdagingen te identificeren, en potentiele verbeteringen te bespreken. Hieronder worden de verschillende hoofdstukken besproken.

\section{Hoe wordt orgaandonatie na euthanasie uitgevoerd}

Het Maastricht UMC+ en het Erasmus MC Rotterdam hebben in 2015 een handreiking opgesteld over de praktische aspecten van orgaandonatie na euthanasie. In hoofdstuk 2 
wordt in een samenvatting van deze richtlijn als een draaiboek beschreven welke stappen uitgevoerd moeten worden om orgaandonatie na euthanasie mogelijk te maken.

Een patiënt dient te voldoen aan de zorgvuldigheidseisen voor euthanasie, zoals vastgelegd in de Belgische en Nederlandse wet. Nadat er over de euthanasievraag een besluit is genomen kan hij vragen om ook in aanmerking te komen voor orgaandonatie. Indien men lijdt aan een maligniteit (kanker) wordt orgaandonatie onmogelijk, en ook de leeftijd speelt een rol. Met name patiënten die lijden aan een neurodegeneratieve ziekte, zoals multiple sclerose (MS), amyotrofische laterale sclerose (ALS) of de ziekte van Huntington zijn in beginsel geschikt om als donor te fungeren, maar ook patiënten met ernstig psychisch lijden hebben reeds orgaandonatie na euthanasie ondergaan.

De uitvoerend arts, meestal een huisarts of een verpleeghuisarts, zal dan - in samenspraak met een transplantatiecoördinator - onderzoeken of er tegenargumenten bestaan voor orgaandonatie bij deze patiënt. Vervolgens dient de patiënt nog enkele voorbereidende onderzoeken te ondergaan, waarbij er onderzocht wordt welke organen (nieren, longen, lever en pancreas) in aanmerking komen voor orgaandonatie. Deze onderzoeken kunnen uitgevoerd worden op de dag van de procedure, of enkele dagen op voorhand. Op basis van de resultaten worden patiënten van de transplantatiewachtlijst opgeroepen.

Op de dag van de procedure wordt de donerende patiënt ontvangen in een patiëntenkamer die zich dichtbij de operatiekamers bevindt, hetgeen ook een kamer op de intensive care kan zijn. Het is van belang dat de procedure in alle rust kan worden uitgevoerd, en dat er eventuele naasten bij aanwezig kunnen zijn. Afhankelijk van de lokale afspraken is het meestal de huisarts die de procedure uitvoert - net zoals euthanasie in de thuissituatie wordt uitgevoerd.

Nadat het overlijden is vastgesteld, en nadat de wettelijk voorgeschreven vijf minuten 'no touch time' zijn verlopen, wordt de patiënt zo spoedig mogelijk getransporteerd naar de operatiekamer, waar de organen uitgenomen worden. De circulatiestilstand vormt namelijk het begin van de zogenaamde warme-ischemietijd (de organen lijden aan zuurstoftekort), die men zo kort mogelijk wenst te houden. Omdat euthanasie in Nederland een niet-natuurlijk overlijden is, behoort de Officier van Justitie (OvJ) toestemming te geven voor zowel de verplaatsing van de overledene als de orgaandonatie. Daarom dient het te verwachten overlijden op voorhand gecommuniceerd te worden met de OvJ, opdat deze snel beschikbaar zal kunnen zijn. 
Ook de gemeentelijk lijkschouwer dient van tevoren geïnformeerd te worden, om op het betreffende moment aanwezig te kunnen zijn en snel een schouwing te kunnen uitvoeren. Vervolgens worden de organen op aangeven van Eurotransplant vervoerd naar de ontvangers. Het is niet mogelijk voor de donor om op voorhand een ontvanger van een specifiek orgaan aan te duiden. $\mathrm{Na}$ de procedure kunnen de naasten desgewenst afscheid nemen van de patiënt in het mortuarium, en/of kan de overledene terug naar huis vervoerd worden.

De inhoud van de handreiking van het MUMC en het Erasmus MC vormde de basis voor de Richtlijn inzake Orgaandonatie na euthanasie, die in 2017 aan de Minister van Volksgezondheid werd gepresenteerd.

\section{Verschillen tussen België en Nederland}

Er bestaan enkele ethische en juridische verschillen tussen België en Nederland inzake orgaandonatie na euthanasie, zoals beschreven in hoofdstuk 3. In België wordt euthanasie beschouwd als een natuurlijk overlijden, waardoor het openbaar ministerie niet bij de procedure betrokken dient te worden. De uitvoerend arts kan hierdoor zelf de overlijdensakte opstellen. In België zijn er handtekeningen nodig van drie verschillende artsen om het overlijden van de patiënt vast te stellen alvorens de organen mogen worden gedoneerd, terwijl dit in Nederland kan gebeuren door één arts die weliswaar niet bij de verwijdering of implantatie van het orgaan betrokken mag zijn. In België worden er vaker barbituraten als coma-inductor gebruikt voor de euthanasie, terwijl er regelmatig heparine (een bloedverdunner) aan wordt toegevoegd om de kwaliteit van de te doneren organen te verbeteren. In Nederland wordt meestal propofol en rocuronium (een spierverslappend middel) gebruikt, conform de richtlijn inzake de uitvoering van euthanasie.

In beide landen bestaan er wel dezelfde ethische dilemma's. Het blijft een discussiepunt of en hoe een arts die geconfronteerd wordt met een patiënt die voldoet aan de zorgvuldigheidseisen voor euthanasie en waarbij er geen contra-indicaties bestaan voor orgaandonatie, de patiënt dient te informeren over orgaandonatie na euthanasie. Een patiënt mag zich niet onder druk gezet voelen om te doneren, en hij mag niet de indruk krijgen dat de euthanasie enkel wordt uitgevoerd omdat hij dan zijn organen zal doneren. De huidige richtlijn stelt dan ook dat beide procedures zo goed mogelijk van elkaar gescheiden dienen te blijven.

In de praktijk blijkt dit weliswaar lastig, omdat de patiënt vaak al eerder in het palliatieve traject vraagt naar de mogelijkheden inzake orgaandonatie. Indien er geen duidelijke 
contra-indicaties bestaan is het van belang dat de arts aan de patiënt duidelijk maakt dat hierover pas gesproken kan worden nadat is vastgesteld dat er voldaan is aan de zorgvuldigheidseisen voor euthanasie. Daarnaast dient men zorgvuldig om te springen met de vraag welke voorbereidende onderzoeken noodzakelijk en wenselijk zijn voor de patiënt, aangezien men deze zo weinig mogelijk tracht te belasten.

\section{Hoe past orgaandonatie na euthanasie binnen het wettelijk kader}

Om orgaandonatie na euthanasie uit te voeren dient men te handelen volgens de bepalingen van enerzijds de Wet inzake Orgaandonatie (WOD) en de Wet toetsing levensbeëindiging op verzoek en hulp bij zelfdoding (WTL). Het handelen van een hulpverlener dient echter ook te passen binnen de Wet op de Geneeskundige Behandelingsovereenkomst (WGBO), en ziekenhuizen dienen zich te houden aan de Wet kwaliteit, klachten en geschillen zorg (Wkkgz). Het uitvoeren van euthanasie door de huisarts in het ziekenhuis, ondersteund door ziekenhuispersoneel, creëert bijgevolg enkele juridische uitdagingen. In hoofdstuk 4 worden deze uitvoerig besproken.

Er wordt onder andere gefocust op de mogelijke aansprakelijkheid van de betrokkenen. Wanneer een arts onrechtmatig handelt, kan hij daarvoor tuchtrechtelijk, burgerrechtelijk en strafrechtelijk aangesproken worden. Stel dat de regionale toetsingscommissie euthanasie tot de conclusie komt dat een orgaandonatie-naeuthanasieprocedure onzorgvuldig werd uitgevoerd. Zij geven dit oordeel dan door aan de Inspectie voor Gezondheidszorg en Jeugd (IGJ), en aan het Openbaar Ministerie (OM). De IGJ kan dan een tuchtzaak aanhangig maken, en het OM kan overgaan tot strafrechtelijke vervolging. De betrokkenen kunnen ook via de burgerlijke rechter een rechtszaak initiëren, waar ze immateriële schade, in beginsel ook affectieschade kunnen vorderen.

De WGBO stelt dat het ziekenhuis verantwoordelijk is voor alle handelingen die binnen de ziekenhuismuren gebeuren. Omdat euthanasie echter als niet normaal medisch handelen wordt beschouwd, is niet de WGBO van toepassing, maar kan er wel nog een beroep gedaan worden op de algemene beginselen inzake de centrale aansprakelijkheid. De arts wordt dan contractueel gezien als een hulppersoon van het ziekenhuis en buitencontractueel als diens ondergeschikte.

Mocht het zover komen dat de strafrechter oordeelt dat de arts aansprakelijk is voor het opzettelijk beëindigen van het leven van een ander op dienst uitdrukkelijk en ernstig verlangen, dan kan er een gevangenisstraf van ten hoogste twaalf jaren worden uitgesproken. Eenieder die betrokken was bij de procedure, dus zowel de andere 
zorgverleners als de raad van bestuur van het ziekenhuis, zou dan als medeplichtig beschouwd kunnen worden. Zij zijn dan namelijk opzettelijk behulpzaam geweest bij het plegen van een misdrijf, of zij hebben hiertoe opzettelijk gelegenheid of middelen verschaft.

Het bovenstaande werd niet geschreven om zorginstellingen en zorgverleners af te schrikken. Men dient er op te kunnen rekenen dat de uitvoerend arts de zorgvuldigheidseisen grondig en correct beoordeeld heeft. Het maakt wel begrijpelijk dat ziekenhuizen terughoudend zijn om orgaandonatie na euthanasie in hun instelling toe te staan, en dat ze soms wensen om de aanvraag zelf te beoordelen. Dit laatste zou hun aansprakelijkheid weliswaar kunnen verhogen.

\section{Hoeveel patiënten komen in aanmerking voor orgaandonatie na euthanasie}

Tussen 2002, het jaar waarin euthanasie gelegaliseerd werd in België en Nederland, en 2018 ondergingen 81418 patiënten euthanasie. In België stonden aan het einde van 20181269 patiënten op de wachtlijst voor een orgaantransplantatie, terwijl er dit in Nederland 1193 waren. Het was echter onduidelijk hoeveel patiënten hun organen zouden kunnen doneren na euthanasie.

In hoofdstuk 5 werd onderzocht wat het potentieel is van orgaandonatie na euthanasie. De geldende criteria voor orgaandonatie werden gebruikt om de geanonimiseerde Belgische euthanasiedata te beoordelen. Eerst werden alle patiënten uitgesloten die aan een maligniteit leden, vervolgens werden de patiënten uitgesloten die aan meerdere aandoeningen leden, en daarna werden per orgaan de verschillende leeftijdsgrenzen gehanteerd.

Er kan geconcludeerd worden dat ongeveer 10\% van de patiënten die euthanasie ondergaan medisch gezien in aanmerking zouden kunnen komen voor orgaandonatie. De patiënt dient dan weliswaar te willen doneren, hij dient voorbereidende onderzoeken te willen ondergaan, en hij dient te willen overlijden in het ziekenhuis. Het daadwerkelijke aantal zal bijgevolg veel lager liggen, maar elke donatie kan meerdere andere levens verbeteren of zelfs redden.

\section{Resultaten van orgaandonatie na euthanasie}

Hoewel de ethische en juridische aspecten van orgaandonatie na euthanasie veel aandacht behoeven, is een andere belangrijke, medische vraag echter of orgaandonatie 
na euthanasie wel het gewenste resultaat oplevert. We weten uit ervaring dat zij die orgaandonatie na euthanasie ondergingen voor hun overlijden tevreden waren over deze mogelijkheid, en dat hun naasten gelukkig waren dat de laatste wens ingewilligd kon worden. De tevredenheid van ontvangers van de na euthanasie gedoneerde organen is van meerdere factoren afhankelijk, waaronder de kwaliteit van het ontvangen orgaan. In hoofdstuk 6 onderzochten we daarom de resultaten van niertransplantaties die gedoneerd werden na euthanasie, en vergeleken we deze met nieren die gedoneerd werden na donatie na DCD, en met nieren die gedoneerd werden na DBD.

DCD wordt meestal uitgevoerd na het stopzetten van de behandeling van een patiënt met een infauste prognose op de intensive care afdeling. Nadat de behandeling gestaakt wordt dient de patiënt binnen de twee uur te overlijden om orgaandonatie mogelijk te maken. Na deze periode hebben de organen namelijk teveel schade opgelopen door een te lage bloeddruk en zuurstofgehalte om succesvol getransplanteerd te worden DBD werd vroeger ook wel 'heart beating donation' genoemd, en is mogelijk bij een patiënt die hersendood is. Nadat er uitgebreide tests werden uitgevoerd om de hersendood vast te stellen worden de organen uitgenomen terwijl het hart nog klopt. Hoewel ook deze organen nadelen ondervinden van de gevolgen van hersendood lijden zij niet aan zuurstofgebrek maar worden ze na uitname snel gekoeld en leiden ze tot gunstige transplantatieresultaten.

De veronderstelling bestond dat orgaandonatie na euthanasie tot betere transplantatieresultaten leidt dan DCD, en mogelijk even goede resultaten als DBD. Patiënten die orgaandonatie na euthanasie ondergaan lijden meestal aan een neurodegeneratieve ziekte, waarbij de te doneren organen goed blijven functioneren. Bovendien is het overlijdensproces bij euthanasie door de euthanasiemedicijnen veel korter dan bij het stopzetten van de behandeling.

We vergeleken 73 niertransplantaties na orgaandonatie na euthanasie met 1212 transplantaties na DBD en 1234 transplantaties na DCD. De conclusie van deze studie was dat nieren die getransplanteerd werden na euthanasie 3,4 keer minder risico hadden op een vertraagd functioneren dan nieren getransplanteerd na DCD. Globaal gezien functioneerden nieren gedoneerd na euthanasie op korte termijn even goed als nieren gedoneerd na hersendood en zelfs beter dan nieren gedoneerd na circulatoir arrest. 


\section{Minderjarigen}

In hoofdstuk 7 beargumenteren we dat orgaandonatie na euthanasie ook bij een minderjarige mogelijk moet zijn indien hij dat zelf graag wenst en indien hij medisch geschikt blijkt te zijn. Hoewel dit een zeer gevoelig onderwerp is, zou het zou niet ethisch zijn om het kind zijn laatste wens te ontzeggen.

Ook een minderjarige heeft namelijk wettelijk gezien mogelijkheid in Nederland om vanaf de leeftijd van twaalf jaren euthanasie te ondergaan. Hiervoor dient hij aan dezelfde zorgvuldigheidseisen te voldoen als een volwassene. Indien de minderjarige een leeftijd heeft tussen de twaalf en zestien jaren dienen de ouders zich met de levensbeëindiging te kunnen verenigen. Indien hij tussen zestien en achttien jaren oud is, dienen de ouders bij de besluitvorming te worden betrokken, en is er geen expliciete toestemming vereist.

Daarnaast kunnen kinderen van twaalf jaar of ouder toestemming geven voor het verwijderen van hun organen na overlijden. Er is dus ook wettelijk gezien geen beletsel tegen het uitvoeren van orgaandonatie na euthanasie bij minderjarigen vanaf twaalf jaar. Theoretisch zou een ouder nog bezwaar kunnen uiten na het overlijden van de minderjarige patiënt jonger dan zestien jaar, maar uitsluitend vóór het uitnemen van de organen. Aangezien er in deze leeftijdscategorie echter ook toestemming van de ouders vereist is voor euthanasie, lijkt dit slechts een hypothetische situatie.

In België bestaat er geen minimumleeftijd voor euthanasie, maar de minderjarige dient 'oordeelsbekwaam' te zijn. Daarnaast zijn de voorwaarden voor euthanasie strenger dan bij een volwassene. Zo dient de patiënt beoordeeld te worden door een kinder- en jeugdpsychiater of een psycholoog, moeten de ouders akkoord gaan, en behoort de patiënt in ieder geval binnen afzienbare tijd te overlijden. Zodoende is euthanasie bij minderjarigen bijvoorbeeld niet mogelijk bij psychisch lijden.

Ook hier neemt de juridische basis niet weg dat orgaandonatie na euthanasie bij kinderen een ethisch en emotioneel zeer gevoelige kwestie is. Er dient hierbij wel opgemerkt te worden dat euthanasie bij minderjarigen heel beperkt voorkomt, en dan met name in geval van een maligniteit. Deze patiënten komen bijgevolg niet in aanmerking voor orgaandonatie.

Soms wordt in Nederland discussie gevoerd over de vraag of euthanasie ook mogelijk dient te zijn voor kinderen jonger dan twaalf. Het is af te wachten hoe de gedachten 
hierover zich verder ontwikkelen en wat de eisen voor deze categorie dan zouden worden, en ook wat dit zou betekenen voor orgaandonatie na euthanasie.

\section{Organ donation euthanasia}

Het lijkt misschien wat vreemd om eerst een patiënt te laten overlijden en pas daarna de organen uit te nemen. Dit zorgt namelijk voor zuurstoftekort in de organen, met een negatief effect op de kwaliteit. Er waren ook patiënten die orgaandonatie na euthanasie ondergingen die hun organen wilden doneren terwijl ze onder anesthesie waren, en dus wilden overlijden doordat hun organen werden uitgenomen. Niet alleen zouden de gedoneerde organen dan in beter staat verkeren, het zou dan ook mogelijk worden om het hart te doneren. Hartdonatie is momenteel slechts mogelijk bij een DBD procedure. Recente studies tonen aan dat het hart toch ook gedoneerd zou kunnen worden na een DCD procedure, maar dit werd pas recent geïntroduceerd in België en Nederland. Patiënten die orgaandonatie na euthanasie ondergaan lijken hier weliswaar een zeer geschikte groep voor te zijn.

Bijgevolg werd in hoofdstuk 8 onderzocht wat de medische, juridische en ethische argumenten zijn om orgaandonatie toe te laten bij een patiënt die onder anesthesie is. Dit hebben we 'organ donation euthanasia' (ODE) genoemd. De patiënt overlijdt dan niet door de euthanasiemedicatie, maar krijgt anesthesie alvorens de organen, inclusief het hart, worden uitgenomen, hetgeen dan het overlijden veroorzaakt.

Vanuit medisch perspectief lijkt deze procedure alleen maar voordelen te hebben met betrekking tot de kwaliteit van de organen en het aantal gedoneerde organen. Aangezien de patiënt nog leeft wanneer de organen verwijderd worden, dient juridisch gesproken te worden over het ter beschikking stellen van organen bij leven. Zowel de Belgische als de Nederlandse wet stellen echter dat orgaandonatie bij leven die gevolgen heeft voor de gezondheid van de donor slechts mogelijk is indien de ontvanger van het orgaan in levensgevaar verkeert, en dit gevaar niet op andere wijze even goed kan worden afgewend. Hoewel er nog vanuit medisch en ethisch perspectief gediscussieerd zou kunnen worden over het in levensgevaar zijn van een persoon op de transplantatiewachtlijst, heeft de Nederlandse wetgever zich bovendien gericht op het doneren van één orgaan. In de huidige praktijk betreft het dan meestal nierdonatie. ODE is momenteel dus volgens de Belgische en Nederlandse wetgeving verboden. Indien de wetgevers ODE toch mogelijk zouden willen maken, lijkt het vanzelfsprekend dat men aan dezelfde zorgvuldigheidseisen als voor euthanasie dient te voldoen. 
Hoewel dit ten volle tegemoet zou komen aan de laatste wens van de patiënt, en dus ook zijn autonomie zou respecteren, wordt deze procedure op dit moment ethisch gezien nog als een stap te ver beschouwd. De mentale gevolgen van de procedure voor alle betrokken personen mogen bovendien niet onderschat worden. Naast alle extra druk die voor zowel patiënt, naasten als zorgverleners bestaat bij een reguliere orgaandonatie na euthanasie, zal het bij ODE de chirurg zijn die het overlijden van de patiënt veroorzaakt door het uitnemen van de organen, terwijl hij de patiënt mogelijk niet eens kent.

Het is in ieder geval cruciaal - los van een eventuele wetswijziging - dat vermeden wordt dat het brede publiek de indruk krijgt dat er een 'jacht' op organen bestaat, waarbij vitale organen kunnen worden uitgenomen bij een levende patiënt. Dit druist in tegen de huidige dead donor rule, die het belang van de donor wenst te beschermen. Deze ethische regel stelt dat er nooit vitale organen verwijderd mogen worden wanneer die persoon nog leeft.

Het bovenstaande kan enigszins gecompenseerd worden door de wetenschap dat men bijdraagt aan het vervullen van de laatste wens van de patiënt, en het verminderen van het lijden van patiënten op de transplantatiewachtlijst. Zij die orgaandonatie na euthanasie hebben ondergaan bleken telkens zeer altruïstisch te zijn, en waren heel tevreden dat hun lijden toch een positief gevolg kon hebben voor anderen.

Door eventuele maatschappelijke evoluties zal wellicht nagedacht moeten worden over een mogelijk wetswijziging en daarmee samenhangende richtlijnen aan de nieuwe ontwikkelingen, tenminste indien daar voldoende politiek, maatschappelijk, juridisch en ethisch draagvlak voor bestaat. De hiervoor benodigde aanpassing van de Nederlandse wet inzake orgaandonatie is nog niet opgenomen in de wetswijziging (introductie Actief Donorregistratiesysteem, ADR) die in 2020 zal ingaan. De eerstvolgende mogelijkheid om dit te bespreken zal zijn bij de geplande wetsevaluatie in 2023.

\section{Toekomst}

We gaan ervan uit dat steeds meer patiënten op de hoogte zullen raken van deze gecombineerde procedure, en mogelijk ook hun organen zullen willen doneren na euthanasie. Het is aan de beleidsmakers en zorgprofessionals om erop voorbereid te zijn deze wens te faciliteren. Naast het door ons gevoerde onderzoek inzake de resultaten van niertransplantatie na euthanasie zal er ook langtermijnonderzoek nodig zijn, en zal men ook de resultaten van de donatie van andere organen na euthanasie moeten onderzoeken. Daarnaast kan men zich richten op verbetering van de 
orgaandonatieprocedures. ODE is momenteel ethisch en juridisch nog een brug te ver, maar mogelijk bestaat er een toekomst voor hartdonatie na DCD, waarvoor euthanasiedonoren zeer geschikt lijken te zijn.

Ook op ethisch gebied blijven nog vele studies mogelijk en noodzakelijk. Naast het al dan niet informeren van de patiënt kan er gedebatteerd worden in welke mate de donatiewens invloed mag hebben op het euthanasieverzoek, en of een patiënt ook thuis gesedeerd mag worden voorafgaand aan transport naar het ziekenhuis en euthanasie. Ook de kwestie 'directed donation' is een belangrijk vraagstuk, waarbij een patiënt die zal doneren na overlijden een ontvanger van een orgaan mag aanduiden, hetgeen momenteel nog niet is toegestaan omdat verdeling van de organen gebeurt door Eurotransplant.

\section{Conclusie}

Orgaandonatie na euthanasie is voor patiënten met een euthanasievraag, en daarnaast de wens om nog iets voor één of meer anderen te kunnen betekenen, een zeer waardevolle procedure. Voor patiënten op een wachtlijst voor transplantatie is ieder (extra) orgaan dat ter beschikking komt levensreddend. De wetgeving verzet zich niet tegen een combinatie van beide procedures, ook niet bij minderjarigen vanaf twaalf jaar. Hierdoor heeft deze combinatie de afgelopen jaren in toenemende mate ingang gevonden in de medische praktijk. Zij werd in Nederland al minstens 50 keer uitgevoerd.

Er dient echter verder gedebatteerd te worden over de juridisch-ethische dilemma's rondom orgaandonatie na euthanasie, zoals het informeren van de patiënt die euthanasie zal ondergaan over de mogelijkheid tot orgaandonatie en het uitnemen van de organen bij een patiënt onder algehele anesthesie (ODE). Het is in dit kader uitermate belangrijk om het recht op autonomie van de patiënt te respecteren en zijn laatste wens waar mogelijk in te willigen, maar ook om een negatieve perceptie van het brede publiek te vermijden. Nieuwe ontwikkelingen zoals ODE kunnen in de toekomst aanleiding geven om de wetgeving (verder) te overdenken en mogelijk te wijzigen. 

Summary 



\section{Summary}

This thesis elaborates on the medical, legal and ethical aspects of organ donation after euthanasia, a procedure that makes it possible for a patient to undergo euthanasia and to subsequently donate his organs.

\section{Organ donation, and euthanasia}

The legislation on organ donation in Belgium as well as in the Netherlands makes a distinction between living and deceased organ donation. The first situation occurs when eg. someone (during life) donates his kidney to another. When discussing deceased organ donation, there is a distinction between donation after brain death (DBD) and donation after circulatory death (DCD). Kootstra et al. introduced four categories of DCD in 1995. Within this context, organ donation after euthanasia is described as 'category III', comparable to cessation of treatment of a patient admitted to the intensive care (also referred to as: withdrawal of life sustaining therapy). In this scenario, a patient can be an organ donor if death occurs within two hours, avoiding too much hypotension and hypoxia and thus ischemic organs. In more recent literature, organ donation after euthanasia is also referred to as 'category V'.

In the Netherlands, an opt-in system is currently in place, which requires citizens to register one of the following choices 1) yes, I want to be an organ donor, 2) No, I do not want to be an organ donor, 3) I want my relatives to decide and 4) I want a specific person to decide. However, many people do not register at all. From the summer of 2020 onwards, those people will be automatically registered as 'did not object', implying that they would want to be an organ donor, and thus creating an opt-out system. In Belgium, the Organ Donation Act of 1986 introduced an opt-out system, therefore every inhabitant knows he is a potential organ donor, unless he expresses or registers an objection.

A patient who requests euthanasia must meet the following due diligence requirements: the patient must be suffering hopelessly and unbearably, he needs to be well-informed, his request needs to be deliberate and voluntary, no other reasonable options should be available, and a second - independent - physician has to assess the patient.

After euthanasia has been performed, a committee judges whether these requirements were met and whether the physician has acted correctly. In the Netherlands, this investigation is performed by a regional review committee, and in Belgium by the federal control and evaluation committee. 
In 2018, 6126 patients underwent euthanasia in the Netherlands, while in Belgium there were 2357 cases of euthanasia.

\section{History of organ donation after euthanasia}

In 2005, for the first time, there was a patient in Belgium who fulfilled the due diligence requirements for euthanasia and requested her physician to be able to donate her organs as well. Her general practitioner contacted Professor Ysebaert, transplant surgeon at the University Hospital of Antwerp. One week later this patient was able to donate her organs immediately following euthanasia. Even though there were a few more cases in the years to come, they were not published in the scientific or popular media. It took until 2012 before this combined procedure was performed in the Netherlands.

After the first procedures of organ donation after euthanasia were brought to the media, health care providers wondered whether this combined procedure was to be allowed from a legal, medical and ethical perspective. Initially, one reacted cautious, since one was not familiar with the procedure and uncertain about the possible implications. Compared to the decades that were required before euthanasia was legalized, it took a relatively short time before the combination of euthanasia and organ donation found its way into medical practice. It turned out it was not necessary to amend the legislation, because euthanasia and organ donation were no new legal procedures in the Netherlands; only the combination of both brought about a change.

This thesis aims to outline current practice on organ donation after euthanasia, to identify the challenges, to investigate the outcome of kidney transplants following organ donation after euthanasia and to discuss potential improvements. Its chapters are discussed below.

\section{How is organ donation after euthanasia performed}

The hospitals Maastricht University Medical Center+ (MUMC+) and Erasmus MC Rotterdam created a practical manual in 2015 on organ donation after euthanasia. In Chapter 2 one can find a summary of this practical manual, identifying which steps need to be taken to make organ donation after euthanasia possible.

A patient must meet the due diligence requirements for euthanasia, as laid down in Belgian and Dutch law. After a decision has been made on the euthanasia request, he can ask whether he is eligible for organ donation. If the patient suffers from malignancy, 
organ donation becomes impossible, while age also plays a role. Patients suffering from a neurodegenerative disease, such as multiple sclerosis (MS), amyotrophic lateral sclerosis (ALS) or Huntington's disease are often suitable as a donor, also patients with severe psychiatric suffering have undergone organ donation after euthanasia.

The performing physician, usually a general practitioner or a nursing home physician, will then - after consulting a transplant coordinator - investigate whether there are any contraindications for organ donation in this patient. The patient has to undergo a few preparatory examinations, to investigate which organs (kidneys, lungs, liver and pancreas) are eligible for organ donation. These examinations can be performed on the day of the procedure or a few days in advance. Based on the results, potential recipients are already informed and called to their hospital.

On the day of the procedure, the patient is admitted to a patient room close to the operating rooms, which can also be a room in the intensive care unit. It is important that the procedure can be carried out in peace and that any relatives can be present. Depending on the local agreements, it is normally the general practitioner who performs the procedure - analogous to performing euthanasia at home.

After death has been determined, and after the legally prescribed five minutes 'no touch time' have elapsed, the patient is quickly transported to the operating room, where the organs are procured. Together with circulatory arrest, the so-called warm ischemia time (WIT - the organs suffer from oxygen deprivation) commences, which should be as short as possible to avoid too much damage to the organs. Since euthanasia is a non-natural death, the public prosecutor should give permission for both transporting the deceased and the organ donation procedure. Therefore, the planned procedure is communicated in advance with the public prosecutor so he is able to act quickly.

The municipal coroner must also be informed in advance, to perform the legally required post-mortem examination immediately after death has been determined. The procured organs are then transported to the recipients at Eurotransplant's instructions. It is not possible for the donor to designate a recipient of a specific organ in advance. After the procedure, the relatives can say goodbye to the patient in the mortuary, and/or the deceased can be transported back home.

The content of the practical manual from the MUMC+ and the Erasmus MC were the basis of the Guideline on organ donation after euthanasia, which was presented to the Minister of Health in 2017. 


\section{Differences between Belgium and the Netherlands}

There are some ethical and legal differences between Belgium and the Netherlands regarding organ donation after euthanasia, as described in chapter 3 . In contrast to Belgium, euthanasia in the Netherlands is regarded as a non-natural death, which implies that a combination with organ donation requires cooperation with the public prosecutor and the municipal coroner. In Belgium, signatures from three different doctors are needed to determine death of the patient before the organs can be donated. In the Netherlands, this can be done by one physician who is not allowed to be involved in the removal or implantation of the organs. In Belgium, barbiturates are used more often for euthanasia, and heparin is regularly added to the euthanasia drugs, to improve the quality of the donated organs. In the Netherlands, the guideline on how to perform euthanasia states that a coma inducer and a muscle relaxant are required, which are usually propofol and rocuronium.

However, the same ethical challenges apply in both countries. It is still a topic of debate whether and how a physician, who is confronted with a patient who meets the due diligence requirements for euthanasia and for whom there are no contraindications for organ donation, should inform the patient about the possibility of organ donation after euthanasia. A patient should not feel any pressured to donate, and he should not get the impression that euthanasia is only performed because he will then donate his organs. Giving information about organ donation after euthanasia to the patient could cause a breach of trust, while withholding it might have the same effect.

The practical manual and current guideline state that both procedures should be kept separate as strictly as possible to avoid any interference and conflict of interests. This appears to be very difficult in practice, since the patient often wants to discuss organ donation earlier in the palliative care trajectory. The subject should only be discussed after both the treating and independent physician have determined officially that all due diligence requirements have been met. Next to that, care should be taken as to which preparatory examinations are necessary and desirable for the patient, as one should minimize the burden for this patient.

\section{How does organ donation after euthanasia fit within the legal framework}

When performing organ donation after euthanasia, one must act in accordance with the provisions of the Act on Organ Donation and the Termination of Life on Request and Assisted Suicide Act. However, the actions of a care provider must also meet the standards of the Medical Treatment Agreement Act, and hospitals must adhere to the 
Healthcare Quality, Complaints and Disputes Act. Performing euthanasia by the general practitioner in the hospital, supported by hospital staff, therefore creates some legal challenges. These are discussed in detail in Chapter 4.

One of these challenges is the possible liability of those who are involved in the combined procedure. When a physician acts unlawfully, he can be held liable for disciplinary, civil or criminal matters. Suppose that the regional euthanasia review committee concludes that an organ donation after euthanasia procedure was performed without fulfilling all due diligence requirements. They pass this judgment on to the Health Care and Youth Inspectorate and the Public Prosecution Service. The Inspectorate can then start a disciplinary case, and the Public Prosecution Service can proceed to a criminal justice process. The parties involved can also initiate a lawsuit through the civil court, where they can claim immaterial damage, including affection damage.

The Medical Treatment Agreement Act states that the hospital is responsible for all actions that occur within the hospital walls. However, since euthanasia is not considered as 'normal' medical practice, this law does not apply. Fortunately, the general principles of central liability can still be invoked. The physician is then contractually seen as an assistant of the hospital and extra contractually as his subordinate.

Should the criminal court decide that the physician is liable for the intentional requested death of another person, a prison sentence of up to twelve years can be imposed. Anyone who was involved in the procedure, both the other health care providers and the hospital board, could then be considered as accessory. They have been intentionally helpful in committing a crime, or they have deliberately provided the opportunity or means to do so.

The above was not written to deter healthcare institutions and healthcare providers. One should be able to trust the performing physician and on his careful examination of the due diligence requirements. These liability issues however make it understandable that hospitals are reluctant to allow organ donation after euthanasia in their institution, and that they sometimes wish to assess the euthanasia request themselves. However, the latter could also increase their liability.

\section{How many patients are eligible for organ donation after euthanasia}

Between 2002, the year in which euthanasia was legalized in Belgium and the Netherlands, and 2018, 81418 patients underwent euthanasia. At the end of 2018, 1269 patients were on the waiting list for an organ transplant in Belgium. In the Netherlands, 
1193 patients were on the waiting list. It was unclear how many patients might be able to donate their organs after euthanasia.

Chapter 5 investigated the potential of organ donation after euthanasia. The applicable criteria for organ donation were used to assess the anonymized Belgian euthanasia data. First, all patients who suffered from malignancy were excluded, as well as patients who suffered from multiple disorders. Next, exclusions were used for the - then applicable age limits per donated organ.

It can be concluded that about $10 \%$ of patients undergoing euthanasia might be medically eligible for organ donation. Then again, the patient needs to be willing to donate his organs, he has to undergo preparatory investigations, and he must be willing to die in the hospital. Therefore, the actual potential number of organ donation after euthanasia will be much lower. Nevertheless, every single donated organ can improve or even save another one's life.

\section{Results of organ donation after euthanasia}

Although the ethical and legal aspects of organ donation after euthanasia require a great deal of attention, another important medical question is whether organ donation after euthanasia yields the desired result. We know from experience that those who underwent organ donation after euthanasia were satisfied with the possibility to donate their organs, and that their relatives were pleased that their last wish could be granted. And yet, it remained unclear whether the donated organs following euthanasia functioned adequately. In Chapter 6 we therefore examined the results of kidney transplants that were donated after euthanasia, and compared these with kidneys that were donated after DCD, and with kidneys that were donated after DBD.

DCD is usually performed in the intensive care unit, after withdrawal of life sustaining therapy without any prospect of improvement. After treatment is discontinued, death must occur within two hours to make organ donation possible. After this period, the organs have suffered from ischemia through low blood pressure and oxygen levels. DBD was formerly called "heart beating donation", and is possible in a patient who is brain dead. After extensive tests to determine brain death, the organs are removed while the heart is still beating. Although these organs suffer from the consequences of brain death, they do not suffer from a lack of oxygen and lead to favorable transplant results.

The hypothesis was that organ donation after euthanasia leads to better transplant results than DCD, and possibly as good as DBD. Patients who undergo organ donation 
after euthanasia usually suffer from a neurodegenerative disease. The organs to be donated continue to function properly. In addition, compared to withdrawal of life sustaining therapy, the administration of euthanasia drugs makes the dying process much shorter.

We compared 73 kidney transplants after euthanasia with 1212 transplants after DBD and 1234 transplants after DCD. The conclusion of this study was that kidneys transplanted after euthanasia were 3.4 times less at risk of delayed functioning than kidneys transplanted after DCD. Overall, kidneys donated after euthanasia functioned as well as kidneys donated after brain death and better than kidneys donated after circulatory arrest.

\section{Minors}

In chapter 7 we try to argue that organ donation after euthanasia should also be possible in a minor (younger than 18 years of age), provided that he requests this himself and he appears to be medically eligible. Even though this is a very sensitive subject, it would be unethical to deny him his last wish.

In the Netherlands, a minor can undergo euthanasia from the age of twelve. He must meet the same due diligence requirements as an adult. If the minor is between the ages of twelve and sixteen, the parents must agree with the termination of life. If he is between sixteen and eighteen years old, the parents must be involved in the decisionmaking process, but no explicit permission is required.

Next to that, children of twelve years or older can give permission to donate their organs after death. It is thus legally possible to perform organ donation after euthanasia in minors from the age of twelve. Theoretically, a parent could still object after the death of the minor patient under the age of sixteen, but only before the organs were taken out. Then again, parental consent is required for this age category, therefore this is only a hypothetical situation.

There is no minimum age requirement for euthanasia in Belgium, but the minor must be mentally able to make a correct judgement about this question. In addition, the conditions for euthanasia are more strict than for an adult. For example, the patient must be assessed by a child and adolescent psychiatrist or psychologist, the parents must agree and the patient should be expected to die in the near future. For that reason, euthanasia is not possible in minors because of psychiatric suffering. 
Here too, the legal basis does not alter the fact that organ donation after euthanasia in children is an ethically and emotionally very sensitive issue. It should be noted that euthanasia in minors is very uncommon. Moreover, since all minor patients who underwent euthanasia suffered from malignancy, organ donation has been impossible thus far on medical grounds.

Policy makers in the Netherlands regularly discuss whether euthanasia should also be possible for children under the age of twelve. It is currently unclear what this would mean for organ donation after euthanasia in minors.

\section{Organ donation euthanasia (ODE)}

It may seem strange to let a patient die first and then remove the organs. This causes oxygen deficiency in the organs, with a negative effect on quality. There were also patients who underwent organ donation after euthanasia who wanted to donate their organs while under anesthesia, and thus wanted to die as a result of the organ procurement. Not only would the donated organs be in better condition, it would also be possible to donate the heart. Heart donation is currently only possible with a DBD procedure. Recent studies show that the heart could also be donated after a DCD procedure, but this was only recently introduced in Belgium and the Netherlands. Patients who undergo organ donation after euthanasia seem to be a very suitable group for this.

Chapter 8 investigated the medical, legal and ethical arguments for performing organ donation in an anesthetized patient. We have called this 'organ donation euthanasia' (ODE). The patient does not die as a result from the administered euthanasia drugs, but receives anesthesia before the organs, including the heart, are taken out, which then causes death.

From a medical perspective, this procedure only seems to have advantages with regard to the quality of the organs and the number of organs donated. Since the patient is still alive when the organs are removed, this legally classifies a donating organs during life. If organ donation during life would affect the health of the donor, both Belgian and Dutch laws only allow it if the recipient of the organ is in danger to life, and if this danger cannot be averted adequately in another way. Theoretically, one could argue that a patient on the transplant waiting list is always in danger to life, but the Dutch legislator has also focused on donating one organ. In current practice, this usually involves living kidney donation. ODE is thus currently prohibited under Belgian and Dutch legislation. 
Nevertheless, if the legislators would want to make ODE possible, it would seem obvious that the same due diligence requirements should be met as for euthanasia.

Although ODE would fully meet the last wish of the patient, and therefore respect his autonomy, this procedure is currently still considered ethically a step too far. Moreover, the mental consequences of the procedure for all persons involved must not be underestimated. In addition to all the additional pressure that exists for both patient, relatives and healthcare professionals in the case of regular organ donation after euthanasia, in ODE it will be the surgeon who causes death of the patient by removing the organs, while he may not even know the patient.

Regardless of a possible change in the law, it is crucial to avoid that the general public is given the impression that there is a "hunt" for organs, to take vital organs from a living patient. This goes against the current dead donor rule, which wishes to protect the interests of the donor.

The above can be somewhat compensated by the knowledge that one contributes to fulfilling the last wish of the patient, and reducing the suffering of patients on the transplant waiting list. Those who underwent organ donation after euthanasia turned out to be very altruistic, and were very satisfied that their suffering could still have a positive effect on others.

Possible social evolutions may require possible changes to the new developments in the law and related guidelines, at least if there is sufficient political, social, legal and ethical support. The required adaptation of the Dutch Organ Donation Act is not yet included in the legislative amendment (introduction of Active Donor Registration System, ADR) that will take effect in 2020. The next opportunity to discuss this will be with the planned law review in 2023.

\section{Future}

We assume that an increasing number of patients will become aware of this combined procedure, and may also want to donate their organs after euthanasia. It is up to the policymakers and healthcare professionals to be prepared to facilitate their wish. In addition to the research we conducted on the results of kidney transplantation after euthanasia, long-term research will also be needed. The results of donations from other organs after euthanasia will also have to be investigated. In addition, one can focus on improving the organ donation procedures. ODE is currently still a bridge too far ethically 
and legally, but there may be a future for DCD heart donation, for which euthanasia donors seem to be very suitable.

Many studies remain possible and necessary in the ethical field. First, there is the delimma on whether to infom the patient about the possibility of organ donation after euthanasia. Secondly, one can discuss to what extent the wish to donate is allowed to have an impact on the euthanasia request. Thirdly, a thorough discussion is necessary about sedating a patient at home prior to transport to the hospital and euthanasia.

The issue of 'directed donation' is also an important issue, making it possible to designate an organ recipient. Currently, Eurotransplant assigns the transplantations after deceased organ donation.

\section{Conclusion}

Organ donation after euthanasia is a very valuable procedure for patients with a euthanasia request who have the wish to improve the life of others. For patients on a transplant waiting list, every (extra) organ that becomes available is life-saving. The legislation does not preclude a combination of both procedures, not even for minors from the age of twelve. As a result, this combination has become increasingly accepted in medical practice in recent years. It has been performed at least 50 times in the Netherlands.

However, the legal and ethical dilemmas surrounding organ donation after euthanasia need to be discussed further. This includes issues such as informing the patient who will undergo euthanasia about the possibility of organ donation, but also the issue of ODE (the removal of organs from a patient under general anesthesia). In this context, it is extremely important to respect the patient's right of autonomy and, where possible, to grant his last wish. In the future, new developments such as ODE may be a reason to reconsider the legislation and possibly to amend it. 
Valorisation addendum 



\section{Valorisation addendum}

This chapter will touch upon the return of investment prospects for society from the knowledge gathered during this PhD-trajectory. Creating a practical manual on organ donation after euthanasia has made it possible for dozens of patients to be able to donate their organs, and even more patients on the transplant waiting list to receive an organ. Identifying different aspects of the process of organ donation after euthanasia gave rise to a whole new set of questions and dilemmas, and has changed medical practice. Centralizing the importance of the patient's autonomy, different medical, legal, ethical, political and societal were explored in the studies described in this thesis.

The next paragraphs will elaborate on the societal relevance of the studies performed and the conclusions drawn in the various chapters addressing these aspects.

\section{Medical considerations}

Patients who want to undergo organ donation after euthanasia form and add a new group of donors to the donor pool, which was previously non-existent. A patient who requests organ donation after euthanasia belongs to a very specific patient category: compared to 'regular', existing category of donation after circulatory death, he does not receive life sustaining therapy in the intensive care unit prior to the donation procedure. They often suffer from a neurodegenerative disease, which impairs their quality of life, but does not harm their organs.

Organ donation after euthanasia is however not possible in every person who undergoes euthanasia. Patients who want to undergo organ donation after euthanasia are evaluated in the same way as other organ or tissue donors, on the basis of their current medical records and the preparatory investigations. Based on the findings, different organs might be suitable for donation. To have an indication of how many patients are eligible for organ donation after euthanasia, we used the general criteria to investigate the Belgian euthanasia cases in chapter 5.

This has led us to believe that the donated organs can be in at least the same shape as other donations after circulatory death, and perhaps even as donation after brain death. To analyze this assumption, we compared the results of transplanted kidneys after organ donation after euthanasia in chapter 6 . This study confirmed that we need to proceed performing organ donation after euthanasia, since kidneys donated following euthanasia perform better than kidneys transplanted following donation after circulatory death and nearly as good as kidneys transplanted following donation after brain death. Therefore, 
the number of quality adjusted life years (QALY's) was substantially increased. At the same time, this implies a significant reduction of the costs for kidney dialysis.

This thesis describes various medical aspects, namely the criteria a patient must meet in order to be a donor, leading to the conclusion that most patients who undergo euthanasia are not eligible for organ donation, a previous unexplored area of research. Every single donor which is eligible and willing to donate, is however able to improve or save the life of up to six patients. Furthermore, this thesis explores the quality of the kidneys that have been transplanted after organ donation following euthanasia, a research that had not been performed yet.

Drafting the practical manual by Maastricht University Medical Center, together with Erasmus Medical Center Rotterdam, initiated the research. Developing a practical manual was the first step contributing to the initiation of this thesis, which also prompted many other hospitals to think about the practical questions that arise when a patient requests organ donation after euthanasia, and the legal, ethical and organizational thresholds that need to be overcome. As a consequence, these hospitals, their medical professionals, and their board members were prepared when a patient actually submitted a request to donate after euthanasia.

\section{Legal considerations}

In addition to the medical aspects that where elucidated by the studies in this thesis, several legal issues were addressed as well. Even though organ donation after euthanasia had already been performed in Belgium and the Netherlands when starting this thesis, it was nevertheless important to identify the possibilities and challenges of their laws on euthanasia and organ donation. In chapter 3, it was demonstrated that legal differences exist, leading to different ways of performing organ donation after euthanasia in different countries. In Belgium, three physicians need to confirm the patient's death before organs can be donated, while in the Netherlands, euthanasia is identified as an unnatural death. These aspects make it necessary to involve additional health care professionals and legal professionals to be able to fulfill all safeguards. It might be better to align both legislations. Chapter 4 provides an even more detailed overview of the legal aspects of organ donation after euthanasia, with a focus on this procedure in the context of the Medical Treatment Act. To inform lawmakers and policy makers, all possible liability questions were identified and answered.

In addition to the above, when discussing the topic of organ donation after euthanasia at scientific congresses, participants often did not understand why one would perform or 
undergo euthanasia, and were concerned about this procedure in minors, since they were aware of the fact that Belgium and the Netherlands allow for euthanasia in children and adolescents. Chapter 7 discusses that organ donation after euthanasia is possible in minors, from a legal perspective. It is however believed that this will most likely never be performed because of ethical and medical contraindications, like malignancy.

These contraindications however are absent in 'organ donation euthanasia' (ODE): anesthetizing patients so their organs can be procured comparable to 'living donation', making it possible to increase the quality of these organs. Currently, the laws do not allow for ODE yet, as discussed in chapter 8 .

\section{Ethical considerations}

Euthanasia is being performed in people who suffer hopelessly and unbearably. Adding organ donation to euthanasia makes it an even more difficult ethical subject, in every possible way. This thesis has identified and discussed several ethical controversies; Should a physician always inform a patient about organ donation after euthanasia? Is it allowed to inform a patient on whether organ recipients have been found? Is it acceptable to let a patient undergo preparatory investigations before he can donate after euthanasia? This has initiated the debate among healthcare professionals, ethicists and lawmakers.

Answers to these questions are not simple, and both result from and contribute to the contemporary social debate. In ten or twenty years, some people will probably have changed their opinions on organ donation after euthanasia, comparable to the societal acceptance of euthanasia itself throughout the years

Specifically the chapters on organ donation after euthanasia in minors and organ donation euthanasia (ODE) have led to critical responses both domestically as internationally, but are essential to be able to adequately address questions pertaining to (younger) patients who want to let their last wish be fulfilled. These items will most likely remain the subject of an ethical discussion in the next decades. This was and remains the core of this thesis: by allowing organ donation after euthanasia, we have made it possible (and will continue to do so in the future) for patients to have their last wish fulfilled. 


\section{Political and societal considerations}

The publications in this thesis have increased awareness of organ donation after euthanasia, in both medical and non-medical professionals. Next to attention by the media, it has initiated numerous publications drawing attention to the topic, also fueling the public debate on the topic. The ongoing debate on organ donation, fueled by the issues on organ donation after euthanasia as well as opting out of organ donation in the Netherlands has demonstrated the sensitivity of the subject.

When organ donation after euthanasia was mentioned in the media, it became clear that not every member of society accepts this type of procedure. It is evident that there are opponents of euthanasia, of organ donation, and thus of the combination of these two as well. This does not necessarily have to be the consequence of religious beliefs. It is every person's - and most important every patient's - right to oppose to organ donation after euthanasia. When medical professionals did not want to participate in performing organ donation after euthanasia, their conviction has always to be respected.

Without defending or opposing the new law on organ donation, or being in favor or against organ donation after euthanasia it is necessary that people are aware of the importance of making a choice. Thousands of patients on the transplant waiting list rely on other people's altruistic beliefs. In the discussion on organ donation after euthanasia, the suffering of the patient, his relatives on the one hand and the patients on the waiting lists on the other are clearly acknowledged. When performing organ donation after euthanasia, medical professionals who were involved in such procedures have, almost without exception, experienced feelings of relief, gratefulness and appreciation in patients who were able to fulfill their last wish. Despite sadness and grief, the donor as well as his relatives and the recipients were grateful and relieved that something good resulted from a very incomprehensible and frustrating situation.

Apart from the medical, legal and ethical aspects addressed in this thesis, it has had a clear political impact. In the Dutch House of Representatives, parliamentarians have actively inquired about the process of organ donation after euthanasia, and have urged the Minister of Health to create clarity on the possibilities of organ donation after euthanasia. The minister was aware of the drafting of the practical manual, and has thereafter requested the creation of a national Dutch guideline. 


\section{Conclusion}

This research has changed the practice of general practitioners and transplant coordinators, who are confronted with the last wish of a patient who will be undergoing euthanasia. More importantly, it has substantially increased the awareness on organ donation after euthanasia among patients, health care professionals and policy makers. This has led to an increased number of patients requesting organ donation after euthanasia. Nearly all hospitals are now prepared to facilitate this combined procedure, and therefore, patients have an opportunity to have their last wish fulfilled.

It is absolutely necessary for politicians and policy makers to think about the future of organ donation after euthanasia, since this research has identified aspects that could be changed in the law to improve the process of organ donation after euthanasia. In case organ donation after euthanasia would be performed more often, this would have a significant impact on the organization of organ transplant and the procurement teams. This could also have potential future financial consequences for the transplant society, and for the use of operating rooms as well as other personnel. At the same time, this would 


\section{References}

1. Dutch Regional review committee on euthanasia, Annual Report 2002.

2. Dutch Regional review committee on euthanasia, Annual Report 2016 - Accessible: https://www.euthanasiecommissie.nl/binaries/euthanasiecommissie/documenten/jaarversla gen/2016/april/12/jaarverslag-2016/RTEjv2016.pdf.

3. Federal monitoring and evaluation committee on euthanasia, First report to the legislative chambers, June 22, 2004.

4. Federal monitoring and evaluation committee on euthanasia, Seventh report to the legislative chambers, 2014-2015, August 09, 2016 - Accessible: https://overlegorganen.gezondheid.belgie.be/sites/default/files/documents/7_euthanasieverslag_2014-2015-nl_0.pdf. 
List of publications 



\section{List of publications}

\section{Articles}

- J.A.M. Bollen, dhr. W.C. de Jongh, dr. W.N.K.A. van Mook e.a., Protocol organ donation after euthanasia, Maastricht University Medical Center

- J.A.M. Bollen, J.A.M. Hagenaars, G. van Dijk e.a., Practical manual organ donation after euthanasia, Maastricht University Medical Center \& Erasmus Medisch Centrum Rotterdam together with the Dutch Transplant Society

- Bollen J, de Jongh W, Hagenaars J, et al. Organ Donation After Euthanasia: A Dutch Practical Manual. American journal of transplantation : official journal of the American Society of Transplantation and the American Society of Transplant Surgeons. Jul 2016;16(7):1967-1972.

- Bollen J, de Jongh W, Hagenaars H, et al. Organ Donation After Euthanasia: A Pure Act of Altruism Fulfilling the Patient's Last Wish. American journal of transplantation : official journal of the American Society of Transplantation and the American Society of Transplant Surgeons. Mar 2017;17(3):843-844.

- Bollen J, Ten Hoopen R, Ysebaert D, van Mook W, van Heurn E. Legal and ethical aspects of organ donation after euthanasia in Belgium and the Netherlands. J Med Ethics. Aug 2016;42(8):486-489.

- Bollen J, van Smaalen T, Ten Hoopen R, van Heurn E, Ysebaert D, van Mook W. Potential Number of Organ Donors After Euthanasia in Belgium. Jama. Apr 11 2017;317(14):1476-1477.

- Bollen J, van Heurn E, van Mook W. Organ Donation After Euthanasia-Reply. Jama. Aug 08 2017;318(6):576-577.

- Van Smaalen TC, Hof-van Smaalen AS, Van Smaalen-Croes MM, De Jongh W, Bollen JA, Van Heurn LW, Van Mook WN. Orgaandonatie na euthanasie. Huisarts Wet 2018;61(2):49-52. DOI:10.1007/s12445-017-1014-7.

- Bollen JAM, Shaw D, de Wert G, ten Hoopen R, Ysebaert D, van Heurn E, et al. Euthanasia through living organ donation: Ethical, legal, and medical challenges. The Journal of Heart and Lung Transplantation. 2018.

- Bollen JAM, ten Hoopen R, van der Hoeven MAHBM, Shaw D, Brierley J, Ysebaert D, et al. Organ donation after euthanasia in children: Belgian and Dutch perspectives. Archives of Disease in Childhood. Archives of Disease in Childhood 2019;104: 827-830

- Mr. drs. J.A.M. Bollen, prof. dr. L.W.E. van Heurn, prof. dr. D. Ysebaert e.a. , 'Orgaandonatie na euthanasie: juridische overwegingen en vraagstukken', TvGR 2019, p. 107-121 
- Dr. E.J.O. Kompanje, 'Reactie op J.A.M. Bollen et al., 'Orgaandonatie na euthanasie: juridische overwegingen en vraagstukken', TVGR 2019 (43)2. (Met naschrift J.A.M. Bollen et al.)', TvGR 2019, p. 199-207

\section{Presentations}

- Organ donation after euthanasia: A Dutch guideline, Joint Congress British Transplant Society \& Dutch Transplant Society, Bournemouth (United Kingdom), March 2015 (poster)

- Protocol MUMC orgaandonatie na euthanasie, Refereeravond Anesthesiologie MUMC, Maastricht (the Netherlands), March 2015

- Organ donation after euthanasia in the Netherlands, Belgian Transplantation Society Annual Meeting, Brussels (Belgium), March 2015

- Orgaandonatie na euthanasie: Landelijke handreiking, Symposium Limburgse vereniging voor Intensieve Zorgverlening, Kerkrade (the Netherlands), April 2015

- Orgaandonatie na euthanasie, Nationaal Co-assistenten Congres, Egmond aan Zee (the Netherlands), April 2015

- Organ donation after euthanasia in the Netherlands, International Transplant Congress European Society for Organ Transplantation (ESOT), Brussels (Belgium), September 2015

- Orgaandonatie na euthanasie: Landelijke handreiking, Nederlandse OK-dagen, Veldhoven (the Netherlands), October 2015

- Organ donation after euthanasia in the Netherlands, Congress of the International Society for Organ Donation and Procurement (ISODP), Seoul (South Korea), October 2015

- De rol van de IC bij orgaandonatie na euthanasie, Nederlandse Intensivistendagen, 's-Hertogenbosch (the Netherlands), January 2016

- The potential impact of euthanasia on organ donation: Analysis of data from Belgium, International Symposium on Intensive Care and Emergency Medicine, Brussels (Belgium), March 2016

- Organ donation after euthanasia: An ethical controversy, $4^{\text {th }}$ Ethical, Legal and Psychosocial Aspects of organ Transplantation (ELPAT) Congress, Rome (Italy), April 2016

- Organ donation after euthanasia: The first 15 Dutch experiences, $26^{\text {th }}$ Congress of the Transplantation Society, Hong Kong (China), August 2016

- Orgaandonatie na euthanasie: Stand van zaken, Nederlandse OK-Dagen, Veldhoven (the Netherlands), October 2016

- The potential of organ donation after euthanasia, Wetenschapsdag Nederlandse Vereniging van Anesthesiologie, Groningen (the Netherlands), September 2018 
- The potential of organ donation after euthanasia, Pélerin Symposium, Maastricht (the Netherlands), October 2018

- Organ donation after euthanasia in children and adolescents: Exploration of legal framework and medical suitability, International Pediatric Transplant Association Symposium, San Jose (Costa Rica), November 2018

- Organ donation euthanasia (ODE), Ethical, legal and psychosocial aspects of organ transplantation (ELPAT) Congress, Krakow (Poland), April 2019 

Dankwoord 



\section{Dankwoord}

De weg naar dit proefschrift is enigszins kronkelig te noemen. Tien jaar geleden had ik niet kunnen voorspellen dat ik na mijn rechten- en ambulanciersopleiding ook dokter zou zijn of zou promoveren (voor de Belgen: doctoreren). Er zijn in ieder geval veel mensen die ik op deze weg tegen ben gekomen en die bijgedragen hebben aan dit mooie resultaat.

Ik maak graag gebruik van deze gelegenheid om ook de mensen te bedanken die vóór mijn promotie een grote rol gespeeld hebben. Jef Janssen en Johan Luyckx, die me de kracht van het woord en het theater geleerd hebben, hetgeen me zeker heeft geholpen tijdens mijn congrespresentaties. Beste vriend Steven Roox tegen, die ik bijna gevolgd was naar de toneelschool, maar die ik nu met veel trots mag bewonderen op het podium! Dave Noiron, met wie ik als ambulancier de straten (on)veilig kon maken in Borgerhout. Jan Christiaen, om me voor te dragen als directeur van de Belgische Beroepsvereniging van Ambulancediensten (Belgambu).

De geneeskundeopleiding zou nooit zo leuk geweest zijn zonder O.G.D. Hayé. Deze hechte vriendengroep is nagenoeg op dag 1 van de geneeskundeopleiding ontstaan en samen weten we mekaar altijd te vinden voor een leuke avond of gezellig weekend. Ik weet dat jullie allemaal schitterende artsen zijn: Davide Aben, Tom Schiffler, Richard van der Meer, Wouter Rompen, Marlous Vermeulen, Vera Peters, Eveline Dokter, Wieke Pijnenburg, Linet den Ouden, Esmée van Drie en Lieke van Zogchel. In het bijzonder dank ik Stefan Leus die met veel enthousiasme de rol van paranimf wilde vervullen. Ik wens jou en Carline immens veel geluk en liefde met jullie kiwi!

Ik was ontzettend gelukkig toen ik door dr. Gramke aangenomen werd als AIOS Anesthesiologie. Dankjewel aan alle collega's in het Catharina Ziekenhuis te Eindhoven om te zorgen voor een gezellig en bijzonder leerrijk perifeer jaar. Ook dank aan alle collega's van de anesthesiologie en de intensive care in het Maastricht UMC+ om te zorgen voor een toegankelijke en aangename leeromgeving.

Ik wil Gert van Dijk danken om een artikel te publiceren over orgaandonatie na euthanasie. Hierdoor werd de Commissie Medisch-Ethische Aangelegenheden (CMEA) van het Maastricht UMC+ gemotiveerd om mij een protocol te laten schrijven over orgaandonatie na euthanasie. 
Hanneke Hagenaars was in het Erasmus MC Rotterdam begonnen aan een gelijkaardig document, en samen ontwikkelden we de Handreiking orgaandonatie na euthanasie, die later de basis zou vormen voor de nationale richtlijn. Dit was niet mogelijk geweest zonder professor Ysebaert, de pionier van orgaandonatie na euthanasie. Hij was de allereerste die in 2005 hemel en aarde bewoog om mogelijk te maken dat een patiënte haar organen kon doneren na euthanasie.

Hans Fiolet verdient een pluim voor het geloof en vertrouwen dat hij had in de procedure en in ons protocol. Roland Van Hooren wens ik te danken voor de expertise die hij kon inbrengen in het ontwikkelen van het protocol.

Het opstellen van de handreiking was nooit mogelijk geweest zonder de kennis die ik heb mogen uitwisselen met transplantatie-coördinatoren Tineke Wind, Monique Willems, Monique Kouters en Ruud Winkens. In het bijzonder dank aan Tim van Smaalen om me wegwijs te maken in de wereld van de transplantaties, en aan Jasper Kox om mijn SPSS life saver te zijn. Ik hoop dat jullie beiden schitterende chirurgen mogen worden! Ook dank aan de mensen van de Nederlandse Transplantatiestichting (NTS) waaronder Nichon Jansen voor de geweldige samenwerking.

Guido de Wert, Gert van Dijk, professor ljzermans en Mark van der Hoeven, ik ben blij dat jullie mee wilden schrijven aan onze moeilijke artikelen, waarbij jullie inzichten zeer waardevol bleken te zijn. I would like to thank Joe Brierley for having the guts to cooperate in writing on a topic that is not accepted in nearly all other parts of the world, including his own country. Thank you, David Shaw to substantially increase the quality of our articles and create some new insights at the appropriate time. Dank aan Maarten Snoeijs om me aan te zetten tot een verdieping in de statistiek, en dank om het artikel inzake de outcome van hoogstaande statistische analyses te voorzien.

Dit proefschrift is extra bijzonder omdat ik de mogelijkheid kreeg om aan zowel de Faculty of Health, Medicine and Life Sciences als aan de Faculteit de Rechtsgeleerdheid te promoveren. Dit was niet mogelijk zonder de steun van respectievelijk Prof. dr. Scherpbier en Prof. dr. Smits. Daarnaast dank ik de leden van de beoordelingscommissie en de corona voor hun wijsheden en medewerking.

Ik ben Rankie ten Hoopen dankbaar om thesisbegeleider te zijn van mijn rechtenmasters, voor het aanbieden van de minor Gezondheidsrecht - waardoor ik een ontzettend interessant vakgebied ontdekte -, en om mij te betrekken bij het ontwikkelen van het protocol inzake orgaandonatie na euthanasie. Ik ben blij dat $u$ tracht mij juridisch 
scherp te houden. Zonder u zouden de juridische aspecten van dit proefschrift veel minder waardevol zijn geweest.

De immer goedlachse Wim de Jongh dank ik voor de gezamenlijke interesse in (Berner Sennen) honden, motoren en koffie. Ik hoop dat we nog vaak samen op congres kunnen gaan, inclusief koffiebonen en bonenmaler. Ik heb veel respect voor de manier waarop jij je rol als teamleider vervult. Dankjewel om voor deze speciale dag je pak aan te trekken en mij te ondersteunen als paranimf!

Hoewel professor van Heurn promootte dat zijn deur altijd open stond, durfde ik er in het begin als timide Belg niet altijd gebruik van te maken. Ik was dan ook heel dankbaar dat ons contact na uw verhuis zeer efficiënt is gebleven. Dankzij $u$ heb ik grote vorderingen gemaakt in (de subtiliteit van) het wetenschappelijk schrijven. Ik ben er trots op dat we het samen hebben aangedurfd om over een gevoelig onderwerp te schrijven, en ik ben dankbaar dat u hiervoor de harde tegenwind wilde opvangen.

Professor van Mook, ik was bijzonder trots op $u$ toen $u$ professor mocht worden, en ik beschouw $\mathrm{u}$ als een groot voorbeeld. Ik heb veel respect en bewondering voor de manier waarop $u$ verschillende functies combineert en toch voor iedereen voldoende tijd vindt. Ik heb genoten van onze snelle en efficiënte samenwerking, van uw wijze woorden, en van de congressen die we samen beleefd hebben. Het is fijn dat we samen out of the box en ambitieus kunnen denken, en dat u niet bang bent om in mijn plaats tegen schenen te stampen. Ook dank voor het verdragen van mijn ongeduld in de laatste maanden van het traject!

Een aantal personen wil ik danken om het leven een beetje leuker te maken en voor alle hulp: Moniek, Melvin, Chris(toph), Cécile, Claudio, Max, Marc, Joy en Goele, Vincent, Jolijn, Mando, Michiel, Frank en Bert.

Liefste Lieke, dankjewel dat je mij gedurende de voorbije jaren hebt ondersteund in dit promotietraject (en in al mijn andere activiteiten). Excuses voor alle keren dat ik te zeer een workaholic bleek (en alvast excuses voor alle momenten waarop dit zal voorvallen in de toekomst). Ik ben ontzettend trots op het feit dat jij mijn vriendin bent, en op al hetgeen jij nu al in je promotietraject bereikt hebt! Ik twijfel er geen moment aan dat jij een fantastische kinderarts zal worden. Dankjewel om een geweldige bernese mom te zijn voor Wiske! 
Het is gemakkelijker om een goede student te zijn met een goede thuis. Ik ben blij dat mijn ouders altijd voor me klaar stonden en me vrij lieten om alle activiteiten/studies/jobs te doen die ik maar wilde. Ze hebben een topprestatie geleverd door zowel mij als Sven, Marco, Veronique en Maarten met alle mogelijke middelen te ondersteunen. Ik ben blij dat ik mijn ouders zo trots kan maken, net zoals mijn broers en zus mij trots maken. Ik ben er ook van overtuigd dat alle grootouders trots op me waren en zouden zijn.

Mijn laatste dankwoord richt ik aan alle patiënten die het hebben aangedurfd om hun organen te doneren na euthanasie en hun naasten. Aan zij die ondanks hun ernstige lijden toch voldoende altruïsme hebben getoond om andere mensen te helpen. Ook al moesten zij hierdoor voorbereidende onderzoeken ondergaan en moesten zij hierdoor overlijden in het ziekenhuis in plaats van thuis. Ik ben trots op het feit dat België en Nederland kiezen voor een menselijk beleid waarbij mensen controle over hun eigen leven kunnen behouden door euthanasie te kiezen, en daarnaast ook nog eens in de mogelijkheid verkeren om hierbij hun organen te doneren. Hopelijk zullen andere landen in de toekomst leren van dit beleid. 
Curriculum vitae 



\section{Curriculum vitae}

Jan Bollen was born in Genk on July $14^{\text {th }} 1986$ and grew up with his parents in Lanaken, where he attended primary and secondary school. He was a member of the children's municipal council and the board of the municipal youth center, volunteered in first aid, and was active in street theater animation.

In 2005, he started at Maastricht University studying the Bachelor European Law School. He combined this with a course in emergency medical training (EMT) in Belgium, after which he worked as an EMT in Antwerp. This increased his interest in the medical field, because of which he started studying Medicine. During the bachelor, he combined this with a Master European Law School, a Master Globalization and Law and a Minor Health Law at Maastricht University.

After writing a practical manual on organ donation after euthanasia for the Maastricht University Medical Center, he started his PhD trajectory and attended the Postgraduate Health Law and Health Ethics at the University of Antwerp.

From 2014-2018 he was the director of the Belgian professional association of ambulances services, and a member of several government committees on prehospital care.

After being a physician at the department of pediatrics at Zuyderland Sittard, he is currently a $3^{\text {rd }}$ year resident in anesthesiology at Maastricht University Medical Center.

Since 2019, he has joined the council of members and and the committee of residents of the Dutch Association for Anesthesiology.

Jan currently lives in Geldermalsen with his girlfriend Lieke and their Bernese Mountain dog Wiske. 

SHE dissertations series 



\section{SHE dissertations series}

The SHE Dissertation Series publishes dissertations of PhD candidates from the School of Health Professions Education (SHE) who defended their PhD theses at Maastricht University. The most recent ones are listed below. For more information go to: https://she.mumc.maastrichtuniversity.nl

Wilby, K. (02-07-2019) When numbers become words: Assessors' processing of performance data within OSCES

Szulewski, A. (20-06-2019) Through the eyes of the physician: Expertise development in resuscitation medicine

McGill, D. (29-05-2019) Supervisor competence as an assessor of medical trainees

Evaluating the validity and quality of supervisor assessments

Van Rossum, T. (28-02-2019) Walking the tightrope of training and clinical service; The implementation of time variable medical training

Amalba, A. (20-12-2018) Influences of problem-based learning combined with community-based education and service as an integral part of the undergraduate curriculum on specialty and rural workplace choices

Melo, B. (12-12-2018) Simulation Design Matters; Improving Obstetrics Training Outcomes

Olmos-Vega, F. (07-12-2018) Workplace Learning through Interaction: using sociocultural theory to study residency training

Chew, K. (06-12-2018) Evaluation of a metacognitive mnemonic to mitigate cognitive errors

Sukhera, J. (29-11-2018) Bias in the Mirror. Exploring Implicit Bias in Health Professions Education

Mogre, V. (07-11-2018) Nutrition care and its education: medical students' and doctors' perspectives 
Ramani, S. (31-10-2018) Swinging the pendulum from recipes to relationships: enhancing impact of feedback through transformation of institutional culture

Winslade N. (23-10-2018) Community Pharmacists' quality-of-care metrics. A prescription for improvement

Eppich, W. (10-10-2018) Learning through Talk: The Role of Discourse in Medical Education

Wenrich, M. (12-09-2018) Guided Bedside Teaching for Early Learners: Benefits and Impact for Students and Clinical Teachers

Marei, H. (07-09-2018) Application of Virtual Patients in Undergraduate Dental Education

Waterval, D. (26-04-2018) Copy but not paste, an exploration of crossborder medical curriculum partnerships

Smirnova, A. (04-04-2018) Unpacking quality in residency training and health care delivery 